\title{
GREEN CARBON
}

\section{THE ROLE OF NATURAL FORESTS IN GARBON STORAGE}
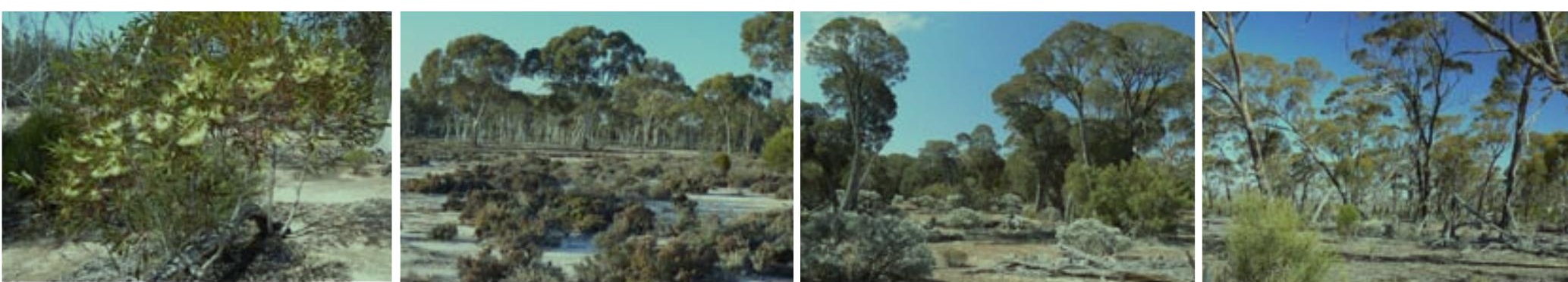

Part 2. Biomass carbon stocks in the Great Western Woodlands

Sandra Berry, Heather Keith, Brendan Mackey, Matthew Brookhouse, and Justin Jonson*

The Fenner School of Environment \& Society, The Australian National University

* Greening Australia, Western Australia 
Published by ANU E Press

The Australian National University

Canberra ACT 0200, Australia

Email: anuepress@anu.edu.au

Web: http://epress.anu.edu.au

Online version available at: http://epress.anu.edu.au/green_carbon2_citation.html

National Library of Australia Cataloguing-in-Publication entry

Title: Green carbon : the role of natural forests in carbon storage Part 2. Biomass carbon stocks in the Great Western Woodlands / Sandra. Berry ... [et al.]

ISBN: 9781921666704 (pbk. : Part 2)

Subjects: Carbon--Environmental aspects.

Forests and forestry--Environmental aspects.

Plants--Effect of atmospheric carbon dioxide on.

Carbon dioxide mitigation.

Other Authors/Contributors: Berry, Sandra L.

Dewey Number: 577.3144

All rights reserved. No part of this publication may be reproduced, stored in a retrieval system or transmitted in any form or by any means, electronic, mechanical, photocopying or otherwise, without the prior permission of the publisher.

Printed by Griffin Press

This edition @ 2010 ANU E Press

Design by ANU E Press

Cover photograph: Eucalyptus woodland, Great Western Woodlands, Western Australia, Sandra Berry 


\section{CONTENTS}

Acknowledgments $\quad 5$

$\begin{array}{ll}\text { Executive Summary } & 7\end{array}$

$\begin{array}{ll}\text { 1. Introduction } & 11\end{array}$

$\begin{array}{ll}1.1 \text { Background } & 11\end{array}$

$\begin{array}{ll}1.2 \text { Aims } & 13\end{array}$

2. Environment and history of the GWW 15

$\begin{array}{ll}2.1 \text { Topography } & 15\end{array}$

$\begin{array}{ll}2.2 \text { Climate range and variability } & 17\end{array}$

$\begin{array}{ll}2.3 \text { Geology and soils } & 19\end{array}$

2.4 Vegetation 20

2.5 Timber cutting in the GWW 25

2.6 Overview of anthropogenic impacts in the GWW 28

3. Methods to calculate carbon stocks 31

$\begin{array}{ll}3.1 \text { Site-specific data } & 31\end{array}$

3.2 Data layers for spatial extrapolation 39

3.3 Extrapolation of carbon stocks from site data 63

4. Spatial biomass and carbon estimates for the GWW, $2008 \quad 69$

5. Biomass and carbon estimates: hypothetical $\begin{array}{ll}\text { no-disturbance scenario } & 77\end{array}$

$\begin{array}{ll}\text { 6. Soil carbon } & 79\end{array}$

7. Management options to protect and restore
the GWW's carbon stocks

7.1 Fire in the GWW 84

7.2 Options for fire management in the GWW 88

7.3 Estimated growth rate of trees in the GWW 89

$\begin{array}{lr}\text { Conclusion } & 93\end{array}$

$\begin{array}{lr}\text { Appendix } & 95\end{array}$

$\begin{array}{ll}\text { References } & 117\end{array}$ 


\section{ACKNOWLEDGMENTS}

This book is based on a report supported by a grant from The Wilderness Society. We would like to thank ANU Enterprise Pty Ltd, which has been involved in the management of the project and has provided support that has been invaluable to the team. Significant components of this report, in particular the field-based plant measurements and the $\mathrm{F}_{\mathrm{PAR}}$ time-series data-set, drew on work funded by Australian Research Council Linkage Project LP0455163 for which The Wilderness Society was an industry partner. Greening Australia kindly made available recently derived equations for some woodland trees and mallee in south-western Western Australia. Professor Ross Bradstock and Dr Rod Fensham provided peer reviews of a draft of this report. We thank them for their constructive comments, which have led to a more comprehensive final document. We thank two anonymous reviewers for their comments on the final document. We thank lan Smith for his assistance with research into the history of timber cutting in the Great Western Woodlands.

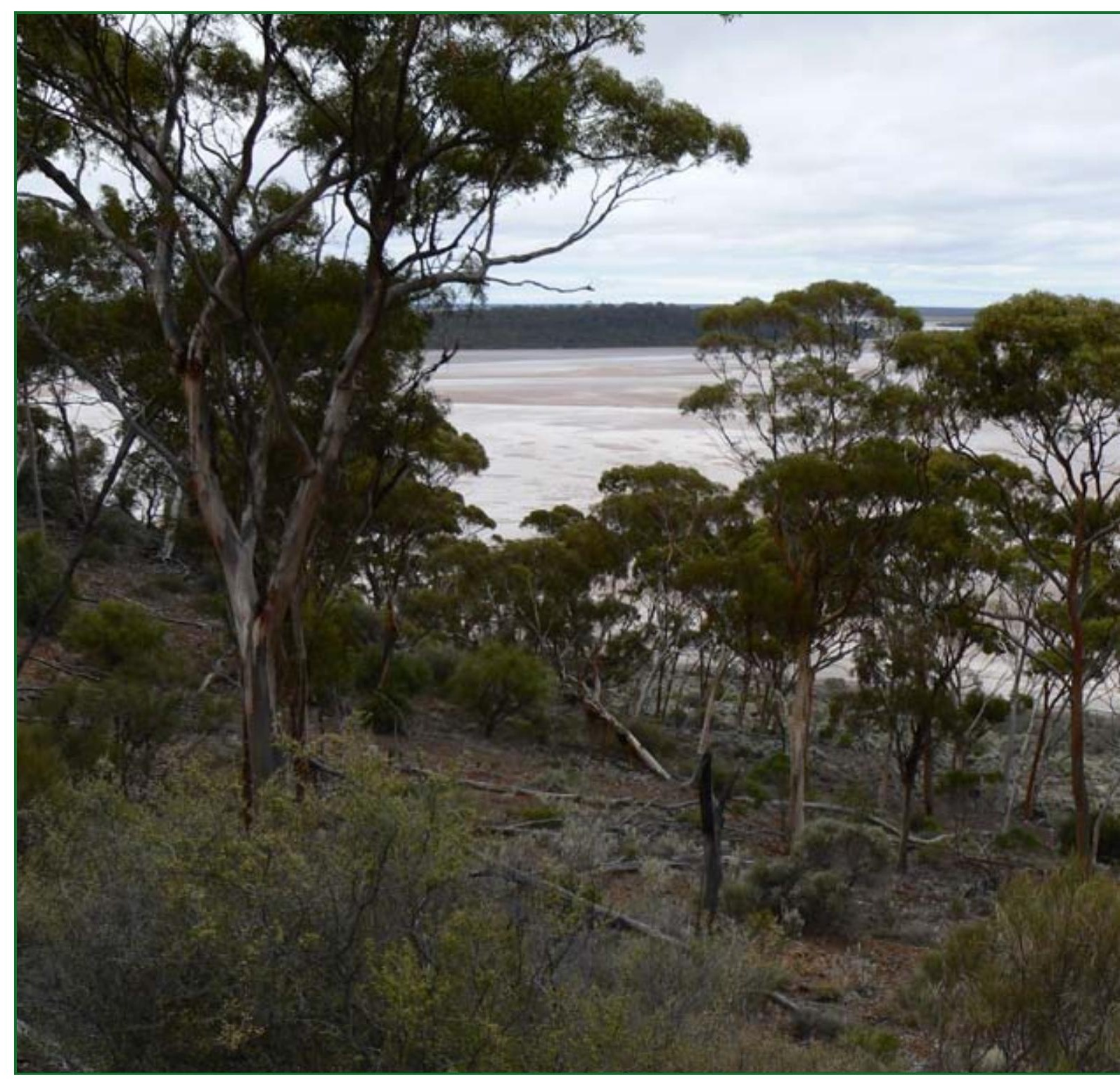





\section{EXECUTIVE SUMMARY}

1. The 'Great Western Woodlands' (GWW) includes most of the contiguous residual natural woody vegetation to the east of the wheatbelt in south-western Western Australia. The conservation status and future of the region are being assessed by various government and non-government stakeholders, and there is a growing need for more quantitative understanding of the environmental services provided by GWW ecosystems-in particular, their role in carbon storage. Our results show that the natural vegetation of woodland and shrubland has been extensively modified by: 1) changed fire regimes (mostly human-induced); 2) timber cutting; and 3) mining and mineral exploration. The condition of GWW natural vegetation and prospects for its ecological restoration need to be factored into conservation planning and related policies and measures for natural resource management.

2. Biomass carbon stocks were calculated using measurements of tree dimensions from 21 field sites covering different vegetation communities within the GWW. Because there is no information specifically for the GWW, allometric equations that relate tree dimensions to biomass were compared from several studies of woodlands in Australia. Equations for woodland sites in Queensland (Burrows et al. 2000, 2002), Northern Territory (Williams et al. 2005) and the wheatbelt in Western Australia (Jonson unpublished) were statistically sufficiently similar to be considered equivalent. The equation from Williams et al. (2005) was selected to convert the GWW site data into estimates of biomass because it included the variables of height and diameter, which account for variations in tree form that are likely due to variations in environmental conditions and as the result of tree damage.

3. Biomass estimated at field sites was extrapolated across the region using: 1) spatial data layers of mapped vegetation types (DEWHA 2005); 2) the fraction of photosynthetically active radiation intercepted by the green foliage of the evergreen vegetation canopy $\left(F_{E}\right)$ derived from MODIS satellite imagery (Paget and King 2008); and 3) disturbance history information about land-use activities associated with timber cutting and mining. Biomass at the 21 field sites was related to $F_{E}$ within four categories of land use and vegetation type: 1) no mineral exploration and no timber cutting in eucalypt woodlands; 2) mineral exploration and no timber cutting in eucalypt woodlands; 3) timber cutting in eucalypt woodlands with or without mineral exploration; and 4) shrublands and non-eucalypt woodlands. Biomass was calculated from the value of $F_{E}$ in each pixel within the spatial extent of each of these four categories. Average total biomass (above and below-ground, living and dead biomass) was $21+\mathrm{C} \mathrm{ha}^{-1}$ and the total for the GWW region was $312 \mathrm{Mt} \mathrm{Cl}^{1}$.

4. We mapped the footprints of extremely severe fires in the GWW over the past 35 years. Wildfire footprints were detected through the analysis of time-series of satellite imagery (1972-2007) and areas that had been burnt once, twice and three times during this period were mapped. These fires have resulted in the death of mature eucalypt tree stems over extensive areas and have initiated a pyric successional vegetation of seedlings and re-sprouts from roots. The pre-fire eucalypt woodland ${ }^{2}$ vegetation structure has, following fire, changed to a pyric successional eucalypt or acacia-dominated shrubland ${ }^{3}$ vegetation structure.

$\mathrm{M}$ (mega) is one million, or in scientific notation, $1 \times 10^{6}$.

Woodland: height of tallest stratum $>10 \mathrm{~m}$; low woodland: height of tallest stratum 5-10 m.

Shrubland: height of tallest stratum $<5 \mathrm{~m}$. 
5. We conclude from our analysis that current vegetation types comprise mostly natural eucalypt woodland and pyric successional stages of shrubland dominated by eucalypt or acacia ${ }^{4}$. These stages are demonstrated by the congruence between boundaries of vegetation mapping units and fire footprints. In accordance with this proposition, we have modified the mapped distribution of eucalypt woodland to account for the changes due to fires that post-date vegetation mapping. This modification involved reclassifying the 1.46 million hectares of eucalypt woodland that had been severely burnt by fires between 1972 and 2007 into tall closed shrublands-a vegetation class that better describes the present pyric successional vegetation structure of eucalypt seedlings, saplings and lignotuber re-sprouts (mallee).

6. Disturbances by human land-use activities that have reduced biomass carbon stocks in the GWW include: 1) increased incidence of fire; 2) mining and mineral exploration on the greenstone lithology; 3) timber cutting; and 4) pastoralism. Field measurement-based estimates indicate that the current above-ground biomass of woodlands recovering from timber cutting (mostly for bio-fuel) in the first half of the past century could be at just 40-50 per cent of the above-ground biomass at carbon carrying capacity. Similarly, the above-ground biomass carbon of woodlands impacted by mineral exploration could be at about 70 per cent of the value at carbon carrying capacity. The change in fire regimes is the major factor. Fire occurrence has increased due to human land-use activities within the GWW resulting in increases in ignition sources. Regeneration of eucalypts after fire as seedlings or re-sprouts produces denser vegetation, providing a more continuous fuel layer that carries more intense fires. These disturbance factors have, over extensive areas, both reduced carbon stocks within vegetation types and changed vegetation structure from woodland to pyric successional stages of dense mallee, marlock ${ }^{5}$ and acacia-dominated shrubland. In a hypothetical scenario of 'no-disturbance' condition-if the woodlands had not been impacted on by fire, timber cutting, mineral exploration and pastoral land management-where eucalypt woodland occupied all the area currently assumed to be under pyric successional stages, a total of 13 million ha (double the current extent and 80 per cent of the GWW) would be woodland, and the total biomass carbon stock would be $915 \mathrm{Mt} C$ (triple the current stock).

7. Soil carbon is the largest pool of terrestrial carbon and some components of the soil carbon store have great longevity. Few data exist to quantify soil carbon in woodlands and specifically in the GWW. We used the spatial data sets of the Australian Soil Resource Information System (CSIRO 2007) and field soil data from Wynn et al. (2006) to estimate an average soil carbon stock for the GWW of $40+\mathrm{C} \mathrm{ha}^{-1}$ and total carbon stock for the A and B horizons of $639 \mathrm{Mt}$ C. Soil carbon stocks likely have been reduced in areas where disturbance has reduced biomass. These estimates of soil carbon can, however, be considered only as indicative; further field survey is a priority.

\footnotetext{
$4 \quad$ Note that heath and other non-eucalypt dominated shrublands and woodlands cover approximately 1.2 million ha of the GWW. Although we have estimated the current carbon stock of these communities, we have not developed a model to estimate their carbon carrying capacity under a no-disturbance scenario as we have no field data for the undisturbed or 'climax' state of these vegetation types. For these vegetation types, the carbon carrying capacity is equated to the current carbon stock.

$5 \quad$ Marlock is the term used to describe dwarf eucalypts having a single stem or mallee-like form but with poor development of a lignotuber.
} 
8. The estimated total carbon stock of the soil and vegetation in the GWW as of January 2008 was $950 \mathrm{MtC}$. Under the hypothetical 'no-disturbance' condition, the total carbon stock is estimated at $1550 \mathrm{Mt}$ C.

9. Maximising carbon stocks in the GWW depends on both avoiding emissions from further degradation and restoring currently degraded eucalypt woodlands. The estimated total biomass carbon carrying capacity of $915 \mathrm{Mt} \mathrm{C}$ within the GWW (for the 'no-disturbance' scenario) should be considered as a maximum possible store of biomass carbon if intense fire had been excluded for several centuries and there had been no timber cutting, mineral exploration or other anthropogenic causes of woodland thinning. Given that the age of trees in undisturbed woodland sites is estimated to cover a range from 100 to 400 years (plus some trees that are very large and possibly very ancient), re-growth of pyric successional stages of vegetation to attain the structure and biomass of eucalypt woodlands would take a very long time.

10. The management of the GWW to maximise carbon stocks would require a substantial reduction in fire frequency and intensity. Ideally, the entire region should be placed under a conservation management planning overlayperhaps analogous to the management of the Great Barrier Reef in its entirety. Changing land tenure from vacant crown land to nature conservation reserve would provide for jurisdiction by the WA Department of Environment and Conservation (WADEC). Management activities by WADEC would need to include restricting vehicular access, providing additional resources for early detection and suppression of fires, imposition of total fire ban periods during conditions of high fire danger and establishing an education campaign to reduce accidental and deliberate ignition events.

11. Conservation management options are most likely to succeed if they can be linked to the emerging carbon market and payments for land stewardship and ecosystem services. Therefore, it is important that state, Commonwealth and international policies and actions recognise the value of avoiding emissions from extant carbon stocks in the GWW, along with the sequestration potential from managing threatening processes. Incentives are needed that will enhance carbon stocks in the GWW through ecological restoration, while avoiding perverse outcomes such as inadvertently providing incentives to clear and degrade natural vegetation ecosystems. 

(3) 


\section{INTRODUCTION}

\subsection{BACKGROUND}

The region referred to as the 'Great Western Woodlands' (hereafter, GWW) includes most of the contiguous residual natural woody vegetation to the east of the wheatbelt in south-western Western Australia. Before European settlement, southwestern Western Australia supported a natural woody vegetation cover of woodland and shrubland (Figure 1.1a). In the past two centuries, about half of this woody vegetation has been cleared and replaced with agricultural production-mostly wheat (Figure 1.1b)-and is commonly referred to as the 'wheatbelt'. The GWW region to the east of the wheatbelt was found to be less suitable for agricultural crops or livestock grazing. Nonetheless, development of the GWW continues to be proposed. In 1979, the WA Government proposed an extension of farming across the southern half of the GWW (Bradby 2008). In 1992, the WA Department of Conservation and Land Management and Goldfields residents established the Goldfields Specialty Timber Industry Group Incorporated with the aim of exploiting the timber resources of the GWW (Siemon and Kealley 1999). Despite early attempts at development, the vegetation remains largely in a natural state in that it has not been subject to broad-scale land clearing and intensive agricultural development. The region, however, overlies the Late Archaean granite-greenstone terranes of the Eastern Yilgarn Craton-geological formations containing high-quality gold and nickel deposits. Consequently, much of the region has been impacted on by mineral exploration and mining. Major impacts on the natural vegetation include: 1) timber cutting before 1975 to provide mining timber and firewood for the goldfields and water-pumping stations; 2) the creation of numerous access tracks and seismic lines; and 3) changes to the fire regime. The impact of changed fire regimes demands special attention as previous studies show that this can lead to the conversion of woodland to a mallee-shrubland vegetation type (Hopkins and Robinson 1981).

The current and future conservation status of the GWW is of increasing concern and there is a need to gain a more quantitative understanding of the environmental services the region provides. The biodiversity significance of the GWW, including its high levels of endemic plant species and the importance of large areas as bird habitat, is known (Duncan et al. 2006; Newby et al. 1984; Recher et al. 2007). Particularly important, however, in the context of the climate change problem, is the role of the GWW's vegetation ecosystems in carbon storage. Carbon storage in natural ecosystems of the biosphere is referred to as 'green carbon' (Mackey et al. 2008). Green carbon is stored in woody plant tissues of living trees and shrubs, dead stems, coarse woody debris on the ground and organic matter (derived from decomposition of plant tissues) in the upper soil layers. The GWW is a large area of natural woodland that potentially includes a significant component of the green carbon stock within Western Australia.

As the world's nations seek solutions to the global problem of climate change, increasing importance is being given to reducing emissions from deforestation and degradation in developing countries-the so-called REDD agenda (UNFCCC 2007). The REDD agenda is, however, not focused on forests in developed countries. From a scientific perspective, as the atmospheric warming caused by a pulse of 
carbon dioxide is the same regardless of the source, it is necessary to consider emissions from natural ecosystems in all countries, including Australia. Emissions from land-use activities in developed countries such as Australia are covered under the so-called 'Land Use, Land Use Change and Forestry' (LULUCF) rules in the Kyoto Protocol. The role of forests and other natural ecosystems in carbon storage is, however, presently unaccounted for by Australia unless deforestation has occurred. Therefore, new policies and measures are needed that reward land stewards for avoiding emissions from, and restoring carbon stocks in, natural forest and woodland ecosystems.

A prerequisite to good climate change mitigation policy is a reliable assessment of an ecosystem's green carbon stocks. Carbon storage in ecosystems can be assessed in terms of their current carbon stock relative to their natural carbon carrying capacity (Keith et al. 2010). Current carbon stock represents the actual carbon stock at a given time and includes the effects of the direct impacts of past disturbances due to human activities such as logging and clearing for pastoralism. Carbon carrying capacity is the amount of carbon terrestrial ecosystems can store when averaged over an appropriate time scale and area, inclusive of the landscape-level impacts of natural disturbance regimes such as fire.

The current carbon stock of terrestrial ecosystems (plants and soil) globally is at least 2000 Gt C, with about 75 per cent in forest ecosystems and 25 per cent in other ecosystem types (Houghton 2007). The international definition of forests, however, includes structural formations that in Australia are defined as woodlands and shrublands (AUSLIG 1990), such as those that characterise the GWW. We need to avoid emissions from all sources if we are to succeed in stabilising atmospheric levels of carbon dioxide at a level that prevents dangerous climate change (IPCC 2007). Protecting and restoring the green carbon stocks in ecosystems such as the GWW can contribute to solving the global climate change problem.

Human activity can lead to either an increase or a decrease in the frequency of fires and a change in fire regimes (that is, the pattern of fire events) (Gill 1975). This change in fire regimes can be considered an indirect effect of humans on an ecosystem's carbon carrying capacity. On a landscape-wide basis, forest ecosystems have been shown to be relatively resilient to fire due to a combination of factors, including: i) the existence of very large old trees that are fire resistant; ii) the presence of tree species with fire-adapted plant life history traits; iii) the occurrence of fire refugia due to landform complexity; and iv) negative feedbacks on flammability (Mackey et al. 2002). The impact of fire regimes on the carbon carrying capacity of woodland ecosystems is, however, poorly studied. As noted above, the available evidence suggests that the woodlands of the GWW could be less resilient to changes in the fire regime than are the wetter eucalypt forests of south-western and south-eastern Australia (Hopkins and Robinson 1981).

In summary, the current carbon stocks of woodland ecosystems can increase or decrease due to: 1) variation in the natural conditions that control plant growth and decay; 2) direct human impacts such as timber cutting and land clearing; and 3) indirect impacts of humans on fire regimes. By definition, carbon carrying capacity represents the carbon stock of an ecosystem inclusive of natural but not anthropogenic disturbance. Therefore, the carbon carrying capacity provides a baseline with which to compare the current carbon stock in order to assess the impacts of human activities. Such analyses make it possible to identify management options for protecting and restoring ecosystem carbon stocks at the landscape scale. 


\subsection{AIMS}

The aims of this report are to

- quantify the current carbon stock of the GWW

- assess how this differs from the carbon carrying capacity

- identify the impacts that have reduced the carbon carrying capacity due to the direct and indirect impacts of human activities

- recommend possible management options for protecting and restoring the carbon carrying capacity of the GWW.

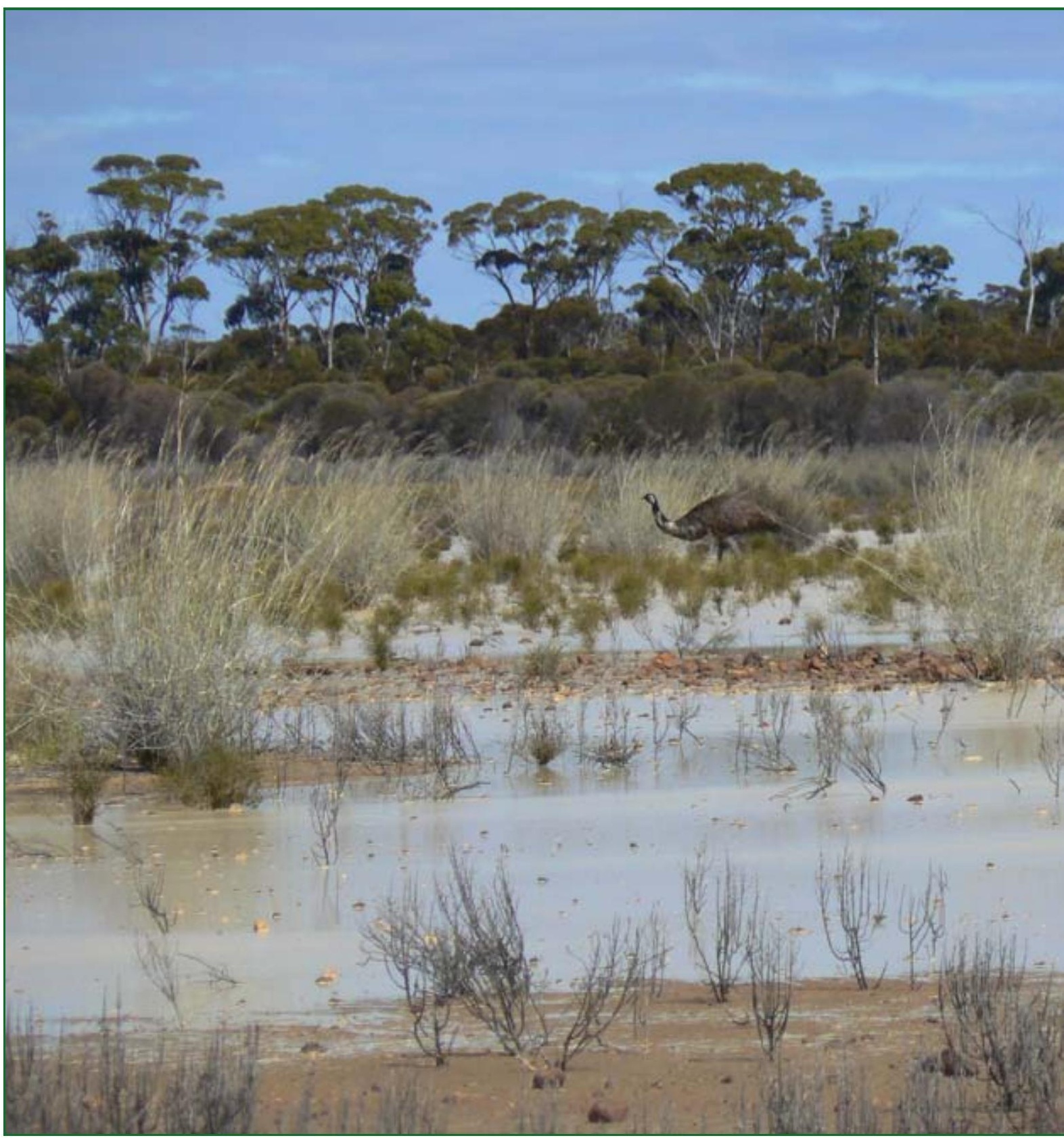




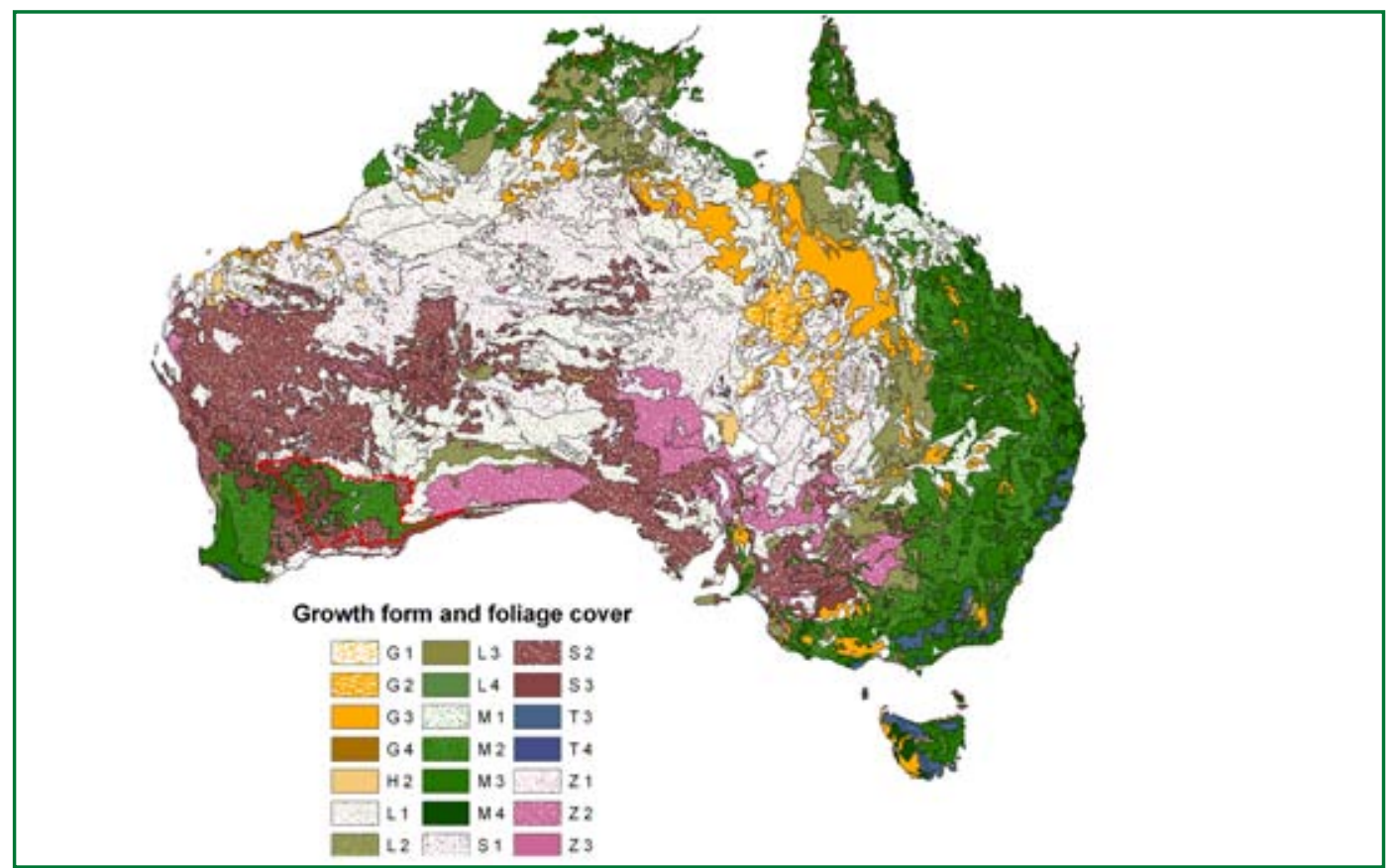

Figure1.1a

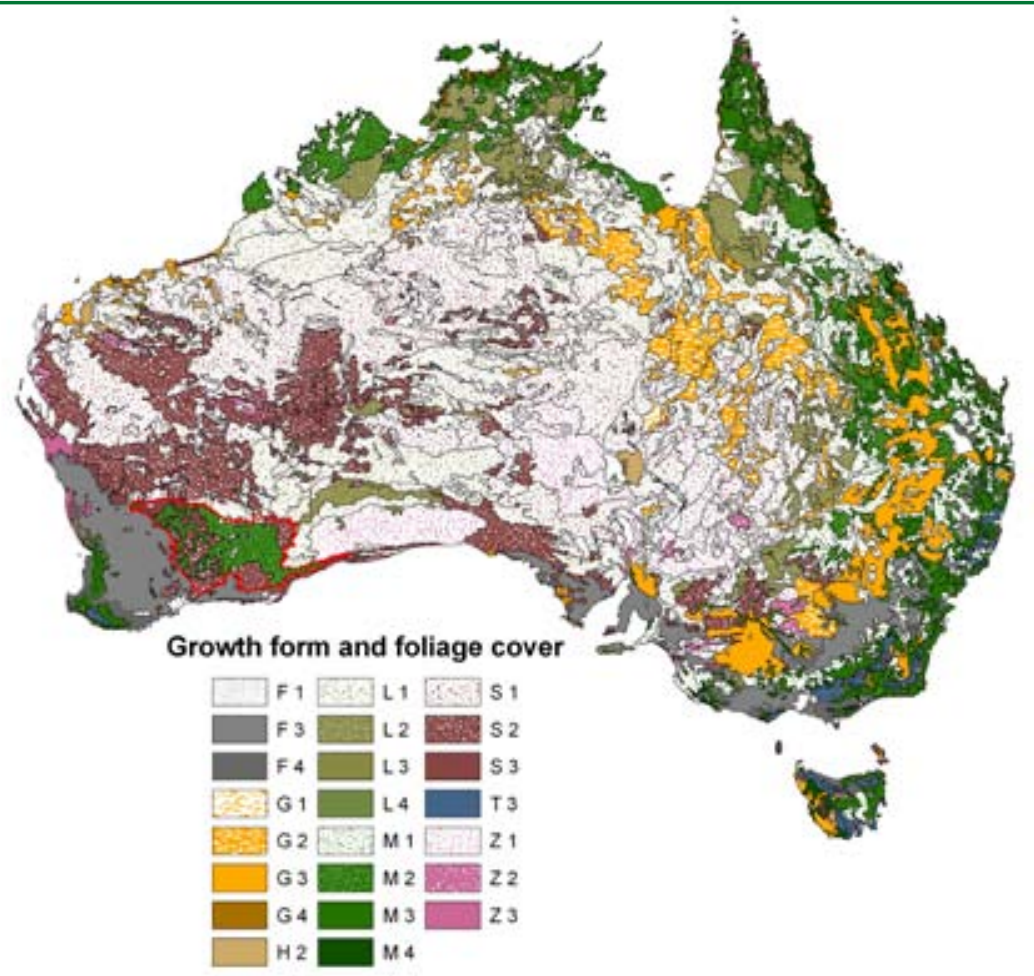

Figure 1.1b

Figure 1.1 Natural vegetation (a) and present vegetation (b) as mapped by Carnahan (AUSLIG 1990). The GWW study area is outlined in red. Vegetation coding: growth form of the tallest stratum is indicated by letters. $T=$ tall trees $(>30 \mathrm{~m}) ; M=$ medium trees $(10-30 \mathrm{~m}) ; \mathrm{L}=$ low trees $(<10 \mathrm{~m}) ; \mathrm{S}=$ tall shrubs $(>2 \mathrm{~m}) ; \mathrm{Z}=$ low shrubs $(<2 \mathrm{~m}) ; \mathrm{H}=$ hummock grasses; $\mathrm{G}=$ tussocky or tufted grasses and graminoids; $F=$ other herbaceous plants. Foliage cover of the tallest stratum is classified into numeric classes: $1=\langle 10 \% ; 2=10-30 \% ; 3=30-70 \% ; 4=>70 \%$.

These figures incorporate natural vegetation and present vegetation data that are Copyright Commonwealth of Australia 2003. 


\section{ENVIRONMENT AND HISTORY OF THE GWW}

This chapter provides an overview of the topography, climate, geology, vegetation and recent land-use history-factors that play a pivotal role in determining the current carbon stock and carbon carrying capacity of the GWW.

\subsection{TOPOGRAPHY}

The land surface elevation of the GWW rises from 140 m near the southern and eastern boundaries to $\sim 500 \mathrm{~m}$ above sea level to the west of Kalgoorlie (Figure 2.1). The region is characterised by broad flat ridges and broad flat valleys (Figure 2.2). There are no rivers to carry water to the sea. The watercourses are shallow and drain internally into chains of salt lakes from which the water evaporates.

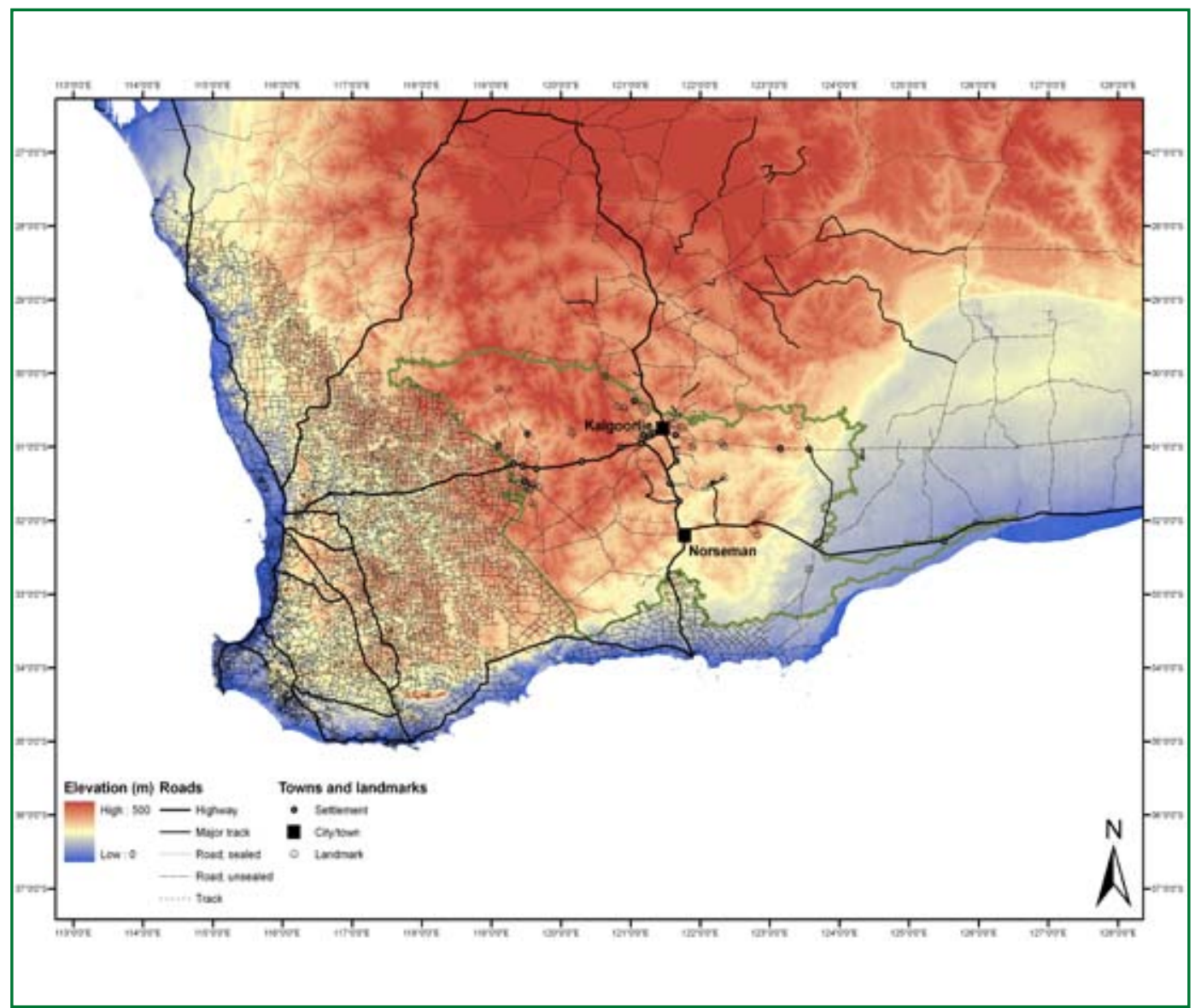

Figure 2.1 Map showing elevation (above mean sea level) of the land surface in southwestern Western Australia. The GWW is outlined in green. Roads, towns and landmarks are also shown.

Spatial data sources: see Table A1-Elevation, Roads, Towns. This figure incorporates Digital Elevation Model Version 3 and Population Centre data, which are Copyright Commonwealth of Australia (2008 and 1998 respectively) and road location data that are Copyright State of Western Australia 2007. 


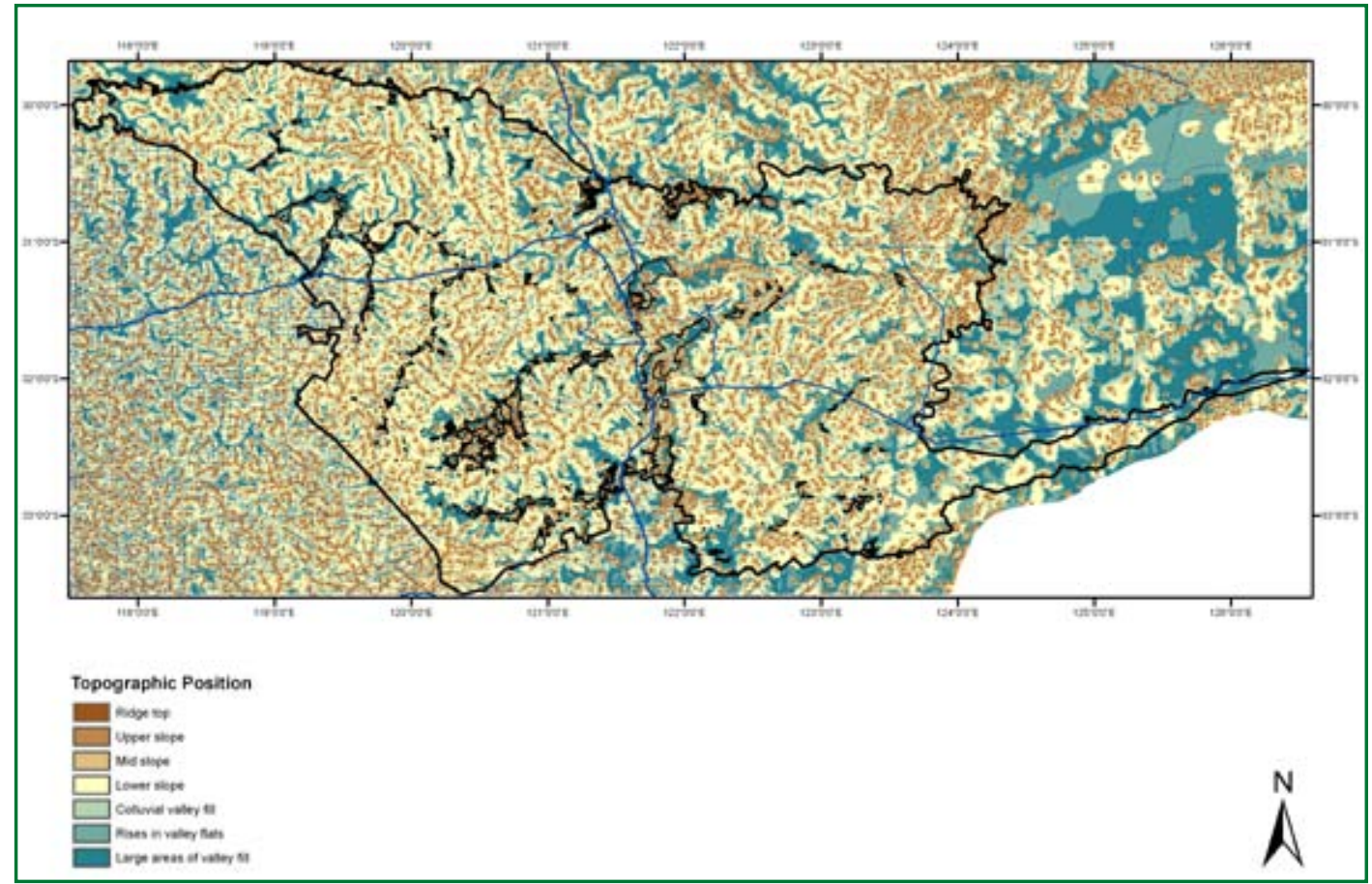

Figure 2.2 Map showing the topography of the GWW. Water courses drain into salt lakes, which are indicated by stippled patterning. Roads are shown as blue lines.

Spatial data sources: see Table A 1-Topo, Roads. This figure incorporates road location data that are Copyright State of Western Australia 2007.

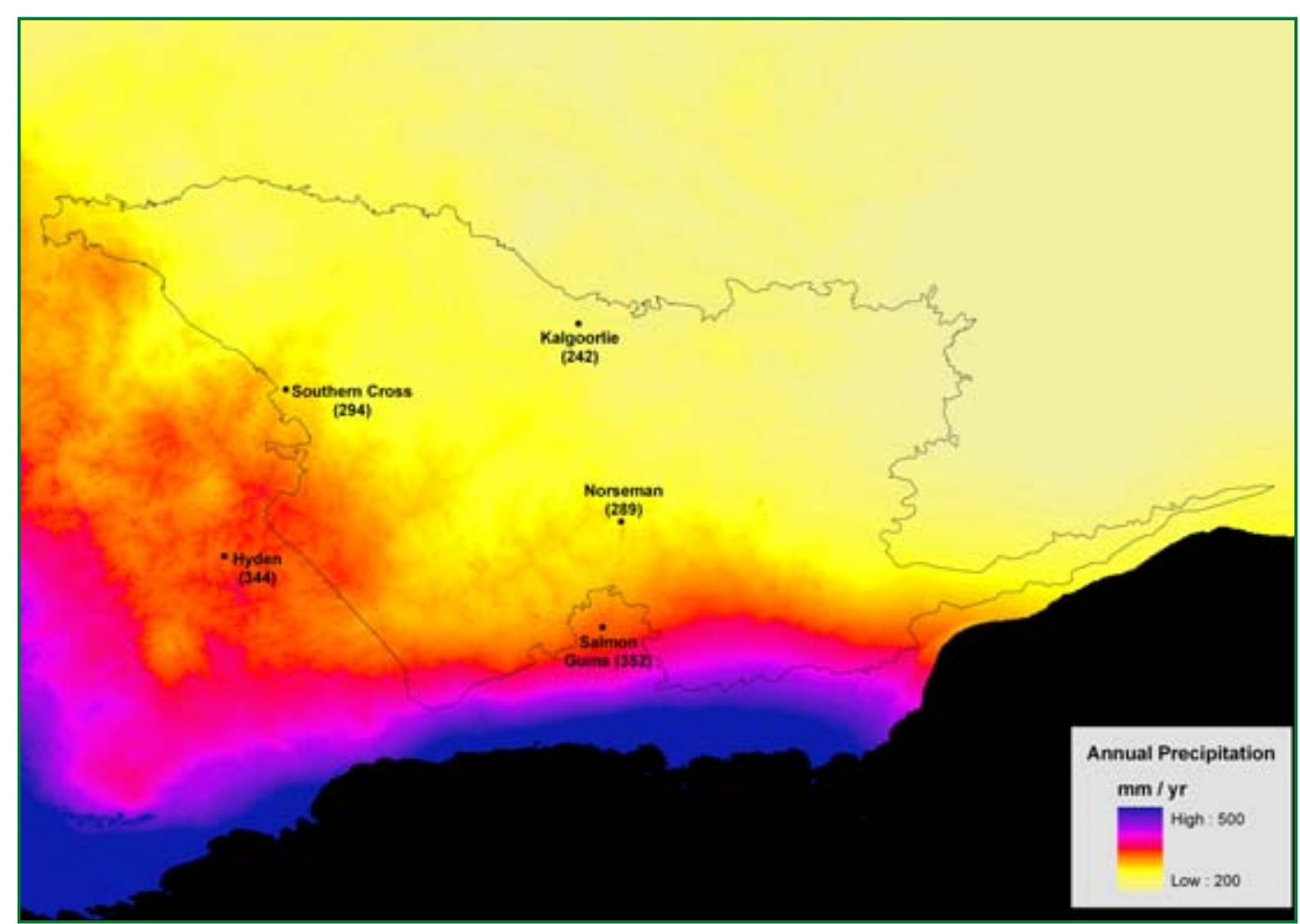

Figure 2.3 Mean annual precipitation over the GWW. Mean annual rainfall $(\mathrm{mm})$ based on the historical record is given in parentheses.

Spatial data source: see Table A l-P. Mean annual rainfall source: Bureau of Meteorology (<http://www.bom.gov. au/>). This figure incorporates climate data that are Copyright Commonwealth of Australia 2009. 


\subsection{CLIMATE RANGE AND VARIABILITY}

\subsubsection{Precipitation}

The rainfall across the whole of the GWW is low-ranging from approximately $350 \mathrm{~mm}$ $\mathrm{yr}^{-1}$ in the south to fewer than $250 \mathrm{~mm}$ in the north of the region (Figure 2.3). Rainfall can occur during any month of the year but there is more pronounced winter rainfall in the south-west, with decreasing seasonality (and total precipitation) to the north-east.

\subsubsection{Temperature}

The GWW experiences long, hot summers and short, frosty winters. The spatial variability in mean maximum (January) and minimum (July) temperatures is shown in Figures 2.4 and 2.5. There is a gradient in maximum temperature with distance from the coast. During the summer, sea breezes have been observed in Kalgoorlie (360 km inland) at about 9 pm (Linacre and Hobbs 1977). Closer to the coast, the sea breeze has a greater cooling effect. Southern Cross experiences an average of 113 days above $30^{\circ} \mathrm{C}$ each year and 11 days above $40^{\circ} \mathrm{C}$. In contrast, Salmon Gums experiences 63 days above $30^{\circ} \mathrm{C}$ and four days above $40^{\circ} \mathrm{C}$. The minimum (July) temperatures in Southern Cross and Salmon Gums are, however, very similar. Both these centres experience about 38 frosty nights a year, while Kalgoorlie and Norseman experience, on average, 22.

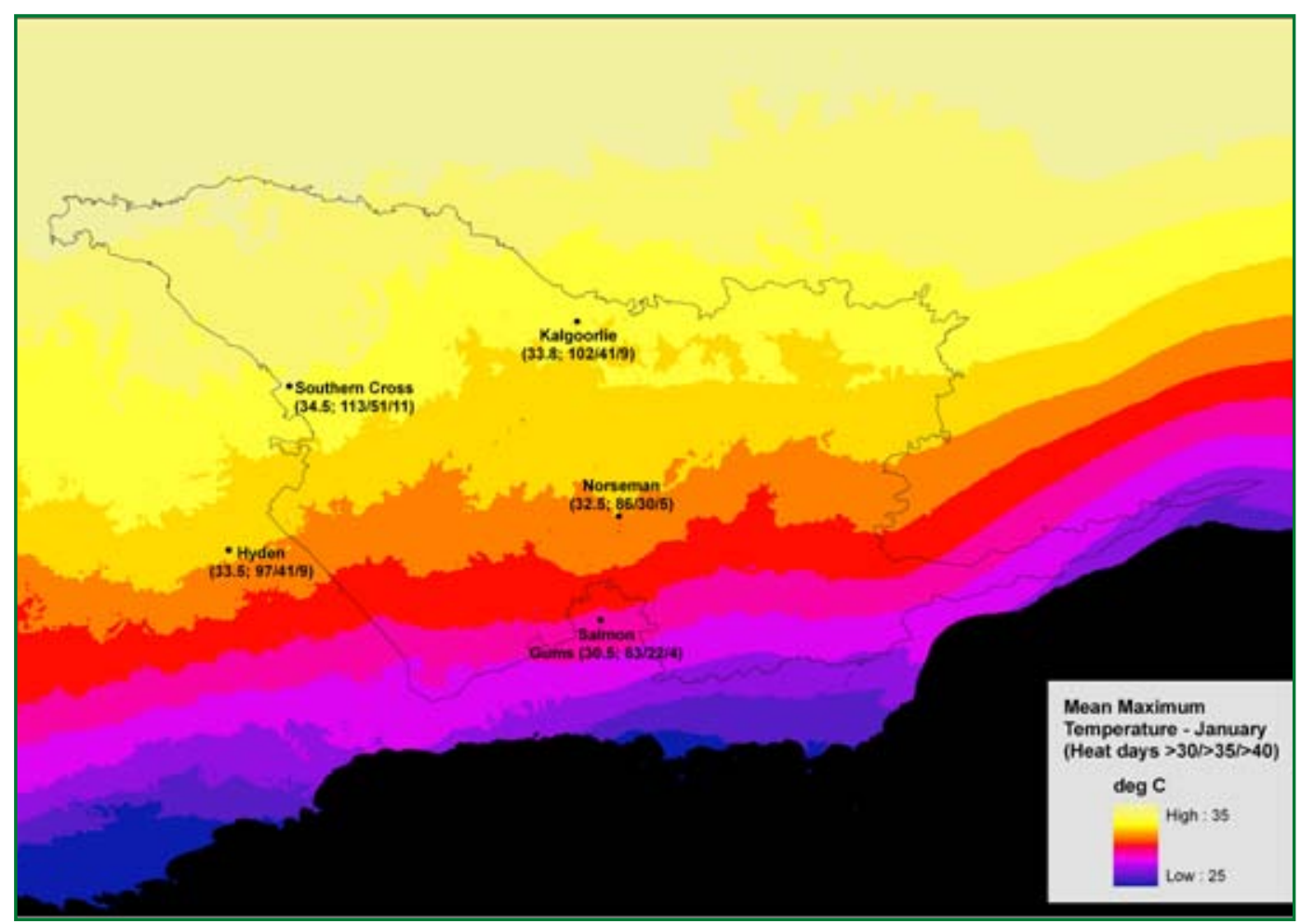

Figure 2.4 Mean maximum daily temperature ( $\mathrm{T}_{\text {max }^{\prime}}$ January) over the $\mathrm{GWW}$. Historical average values of $\mathrm{T}_{\text {max }}$ along with the average number of days each year when $\mathrm{T}_{\max }$ exceeds $30^{\circ} \mathrm{C}, 35^{\circ} \mathrm{C}$ and $40^{\circ} \mathrm{C}$, are given in parentheses.

Spatial data source: see Table A $1-\mathrm{T}_{\text {max. }}$ Historical average value source: Bureau of Meteorology (<http://www. bom.gov.au/>). This figure incorporates climate data that are Copyright Commonwealth of Australia 2009. 


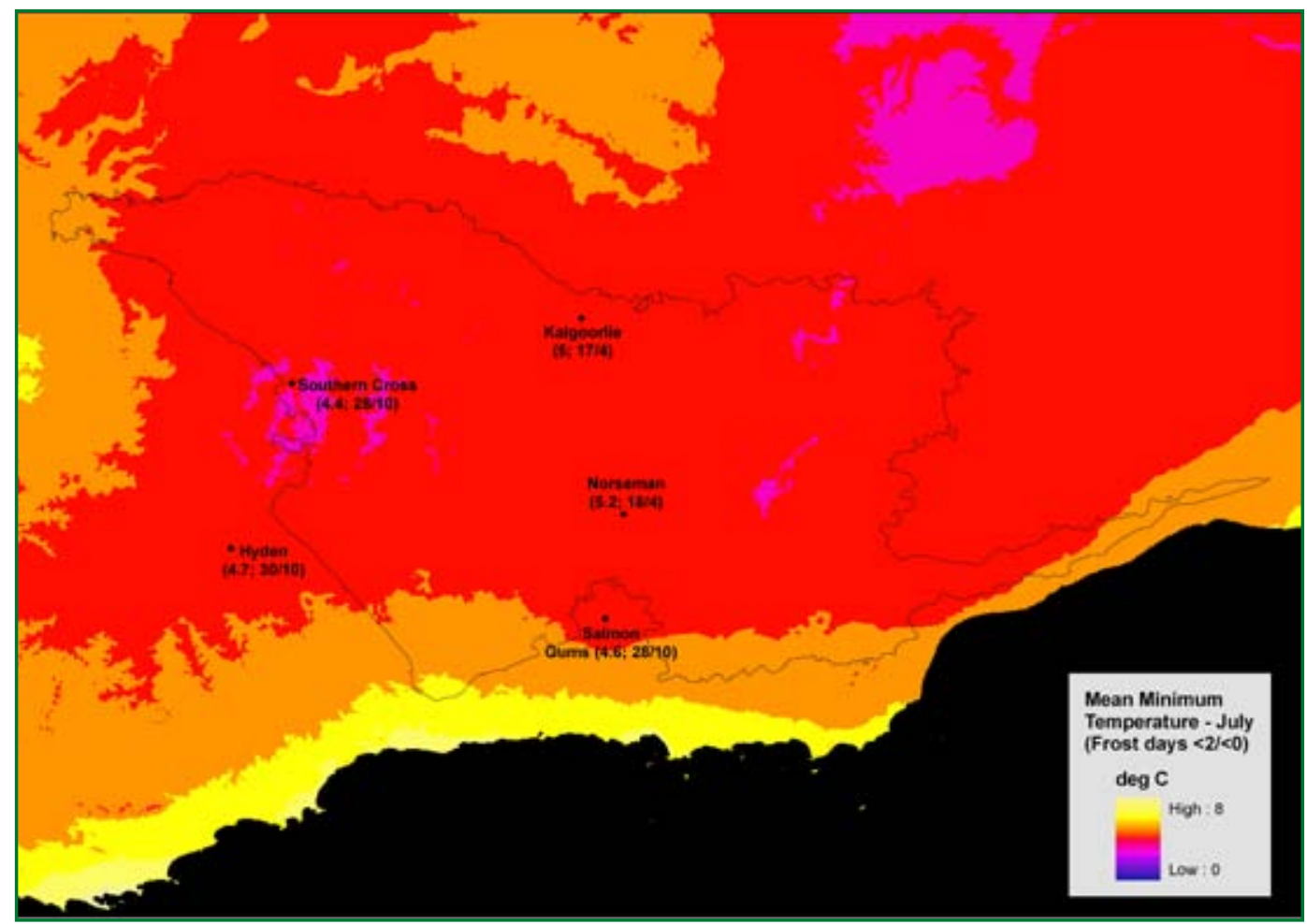

Figure 2.5 Mean minimum daily temperature $\left(\mathrm{T}_{\min }\right.$, July) over the GWW. Historical average values of $\mathrm{T}_{\min }$, along with the average number of frosty nights each year when $\mathrm{T}_{\min }$ is less than $2^{\circ} \mathrm{C}$ and $0^{\circ} \mathrm{C}$, are given in parentheses.

Spatial data source: see Table Al- $T_{\text {min }}$. Historical average value source: Bureau of Meteorology (<http://www.bom. gov.au/>). This figure incorporates climate data that are Copyright Commonwealth of Australia 2009.

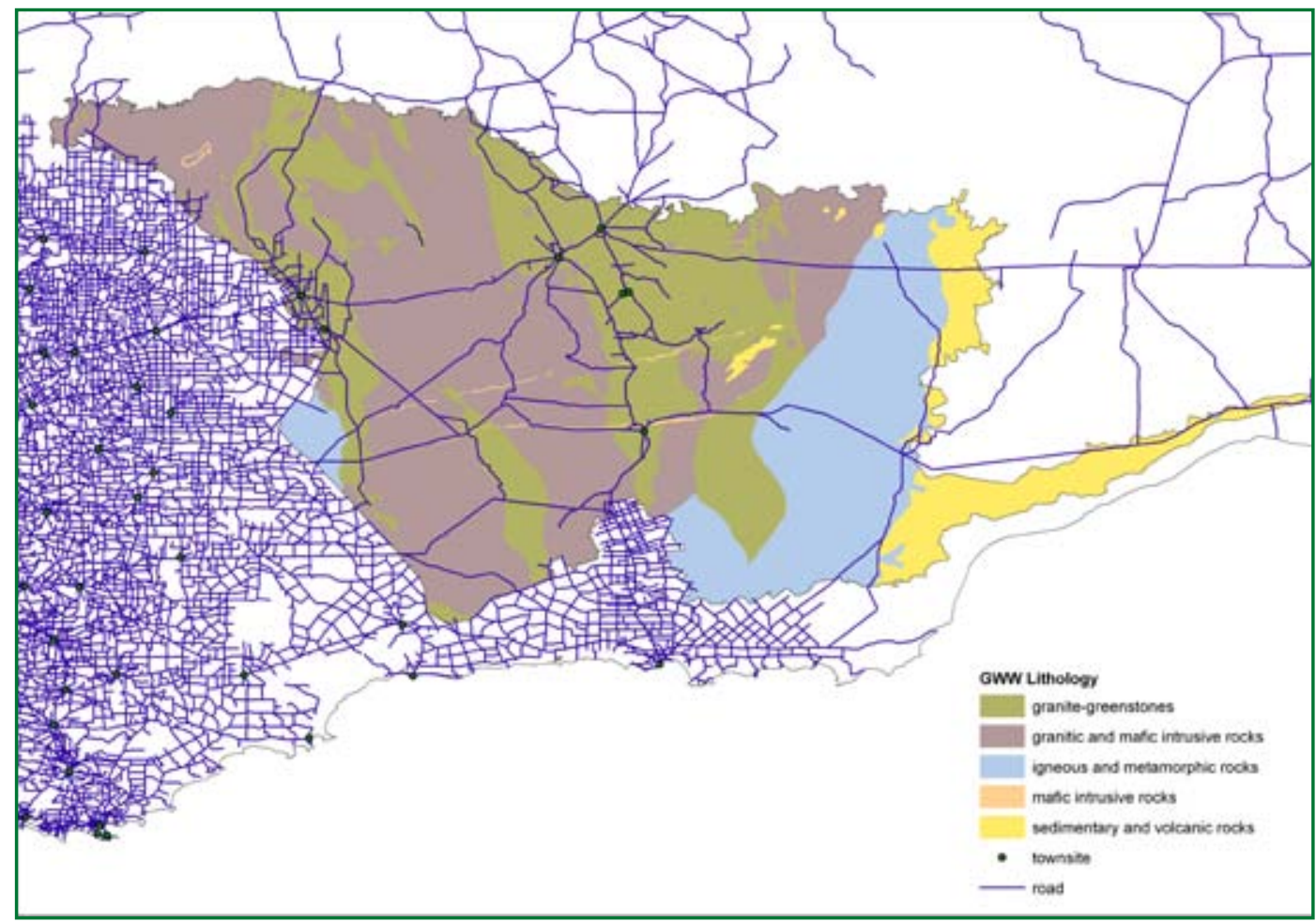

Figure 2.6 Location of major lithological units within the GWW.

Spatial data source: see Table Al-Lithology, Roads, Towns. This figure incorporates population centre data that are Copyright Commonwealth of Australia 1998, and geology and road location data that are Copyright State of Western Australia 2007. 


\subsection{GEOLOGY AND SOILS}

The GWW lies on four major lithological units (Figure 2.6): 1) granite-greenstones; 2) granite and mafic intrusive rocks; 3) igneous and metamorphic rocks; and 4) sedimentary and volcanic rocks. Two thin bands of mafic intrusive rocks traverse the central GWW. The granite-greenstone lithological unit contains the majority of Australia's high-quality gold deposits (Henson and Blewett 2006) in addition to other heavy-metal deposits including nickel. The ancient, deeply weathered landscape has given rise to a range of soil types formed from alluvial (water-transported) and residual sediments, along with areas of exposed bare rock.

The 1:250 000 geological series of sheet maps published by the Geological Survey of Western Australia (2007) provide more detailed mapping of surface geology. (The index to these sheet maps is shown in Figure 2.7.) The surface geology depicted by these sheet maps was generally derived using a combination of field survey and aerial photo patterns, with much dependence on the latter in those areas that were inaccessible by four-wheel-drive vehicle (see Table A2).

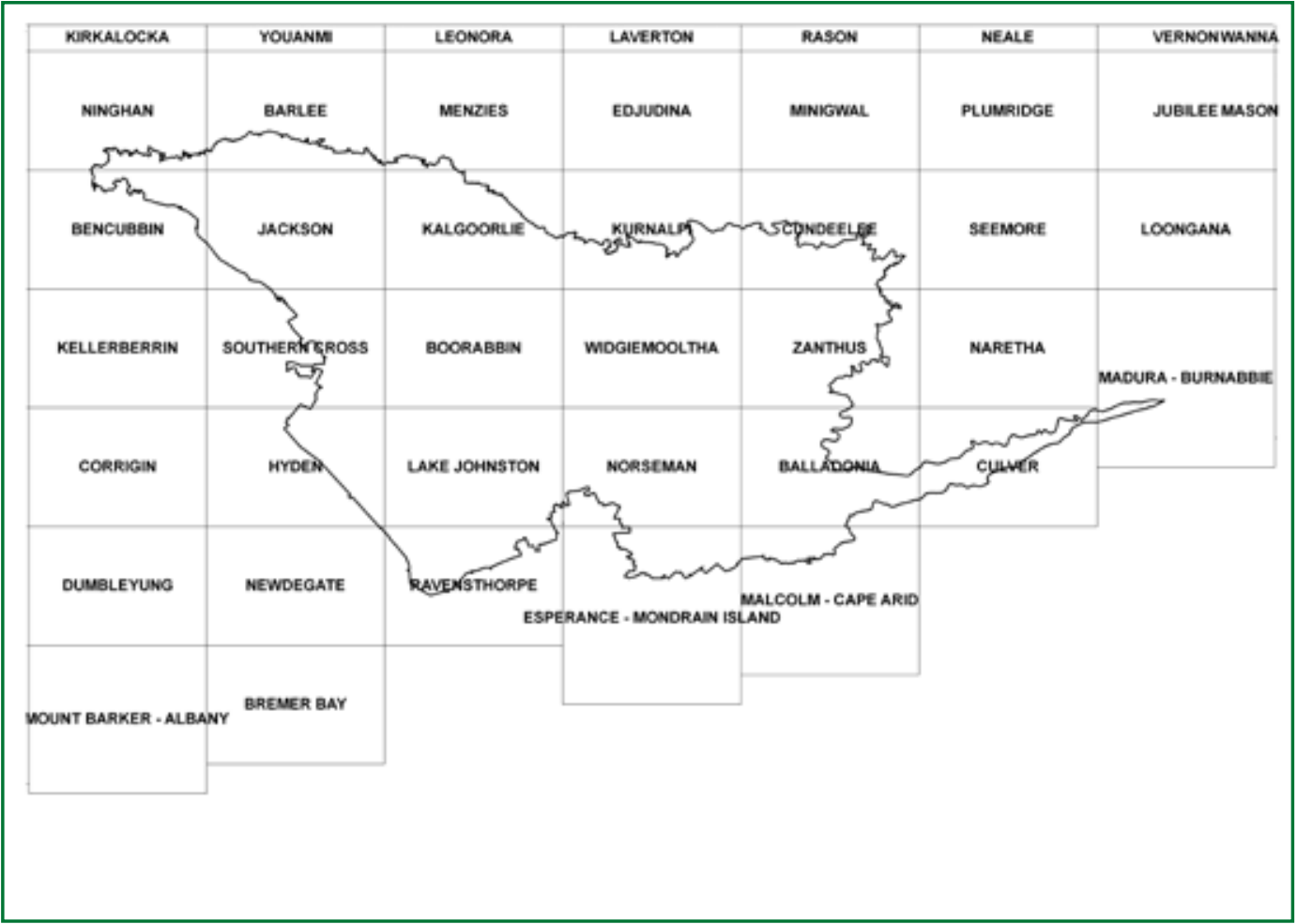

Figure 2.7 Coverage of GWW by 1:250 000 geological series map sheets.

Data sources: see Table A1-Map Sheets and Table A2 for information extracted from the Explanatory Notes that accompany the map series. This figure incorporates map sheet Index250 data that are Copyright State of Western Australia 2007. 


\subsection{VEGETATION}

Surveys of the vegetation of the GWW region by Beard $(1968,1972,1976)$ and the Western Australia Museum (Newby et al. 1984) identified six plant formations: 1) scrub heath; 2) broombush thicket; 3) rock pavement vegetation; 4) mallee; 5) sclerophyll woodland; and 6) halophytes (see Figure 2.8). The relationships between these plant formations, the dominant species and soil types are summarised in Tables A3 and A4. Soil type is an important determinant of species composition as it affects both the availability of nutrients and water storage (Brady and Weil 2002). Leached sands support low scrub heath vegetation (also known as Kwongan). Prominent species in these scrub heath shrublands belong mostly to the Proteaceae and Myrtaceae plant families, while eucalypts are absent. Broombush thickets (tall shrublands) are found on shallow, sandy soils and consist mostly of Casuarina, Acacia and Melaleuca species. Rock pavement vegetation includes a range of plant structures from lichens and mosses through to shrubs that occupy crevices where soil has accumulated. Mallee (multi-stemmed eucalypt) shrublands occur on both leached granite soils and deeper residual and alluvial soils. Sclerophyll (eucalypt) woodlands occur on the deeper soils. The understorey of sclerophyll woodlands is often lacking or is made up of a sparse or open shrub layer or layers or occasionally spinifex. The composition of the understorey shrubs reflects the soil type. Finally, the halophyte plant formation (consisting of succulent or semi-succulent low shrubs) is found on the highly saline depressions around salt lakes.

Distributions of plant formations and the species that constitute them cannot readily be mapped over large areas without homogenisation of finer-scale spatial heterogeneity. Consequently, various classification schemes have been developed, including the schemes used by Carnahan (AUSLIG 1990) and the National Vegetation Information System (NVIS) (DEWHA 2005) for mapping the continent's vegetation cover. Beard (1968) also applied a scheme to map the vegetation for the 1:250 000 printed map sheet series.

Natural (1780s) vegetation and present (1980s) vegetation structural formations, as mapped by Carnahan (AUSLIG 1990), are shown in Figure 2.9. The vegetation structural groups form the framework of Table 2.1. Carnahan's continental vegetation map (AUSLIG 1990) identified five vegetation structural groups in the GWW in both the present (1980s) and the natural (1780s) vegetation. More recent mapping by the National Vegetation Information System (NVIS 3.1; DEWHA 2005) identifies 14 major vegetation groups (MVGs) within the GWW (Figure 2.10). Based on that mapping, the areal extent of the MVGs in the GWW can be estimated using a Geographic Information System (see Table 2.2). We present the NVIS 'extant' vegetation layer in Figure 2.10, but not the NVIS 'pre-1750' layer. These layers differ only where vegetation has been cleared for agricultural crops. Thus, it might be assumed that the vegetation in the GWW has changed little in the past two centuries. As detailed below, however, extensive areas have been impacted on by fire, mineral exploration, pastoralism and timber cutting. Of these impacts, only timber cutting is well documented. 
Figure 2.8. Major vegetation types in the GWW identified by Beard (1968).

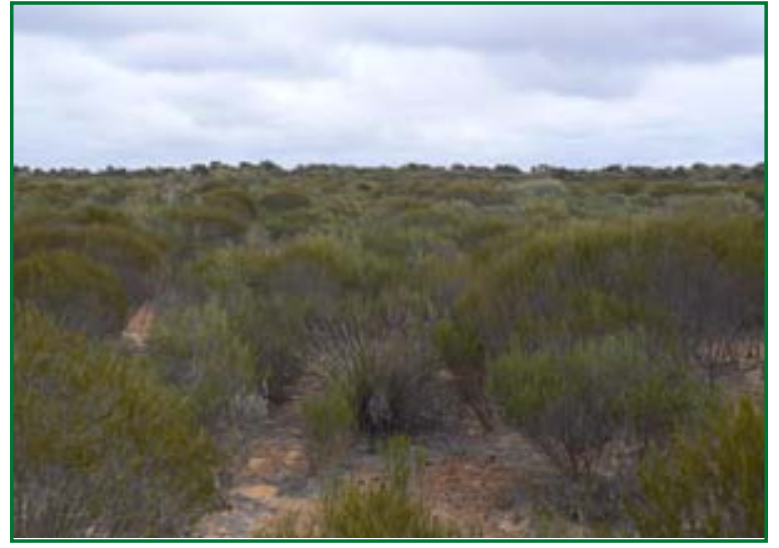

Figure 2.8.1 a Scrub heath.

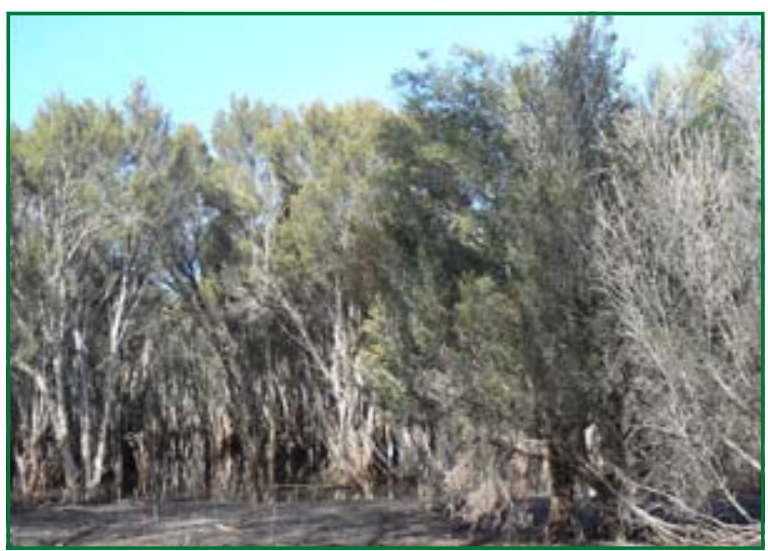

Figure 2.8.2a Broombush thicket.

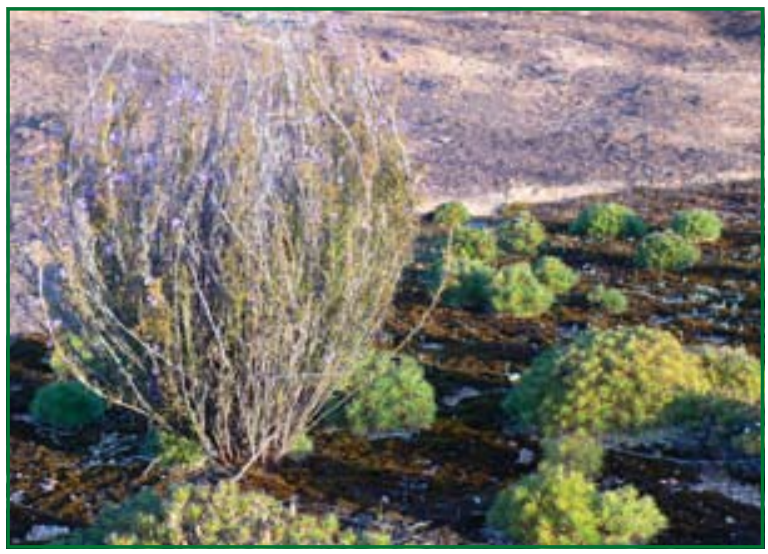

Figure 2.8.3a Rock pavement vegetation.

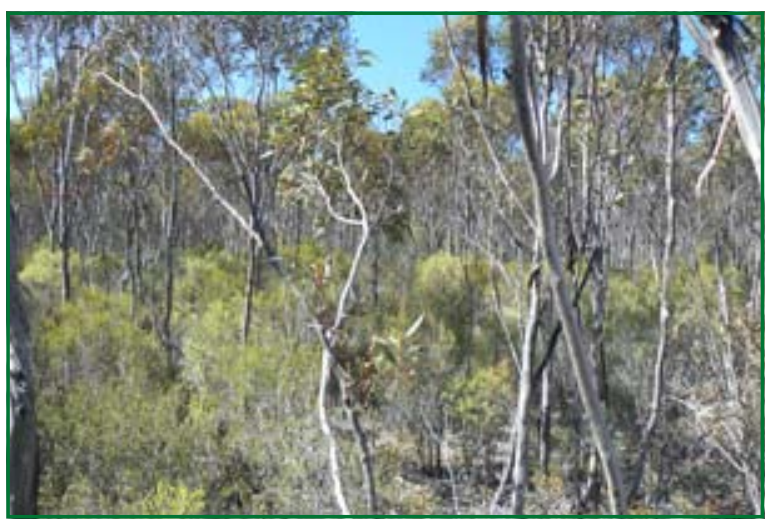

Figure 2.8.4c Mallee shrublands and woodlands.

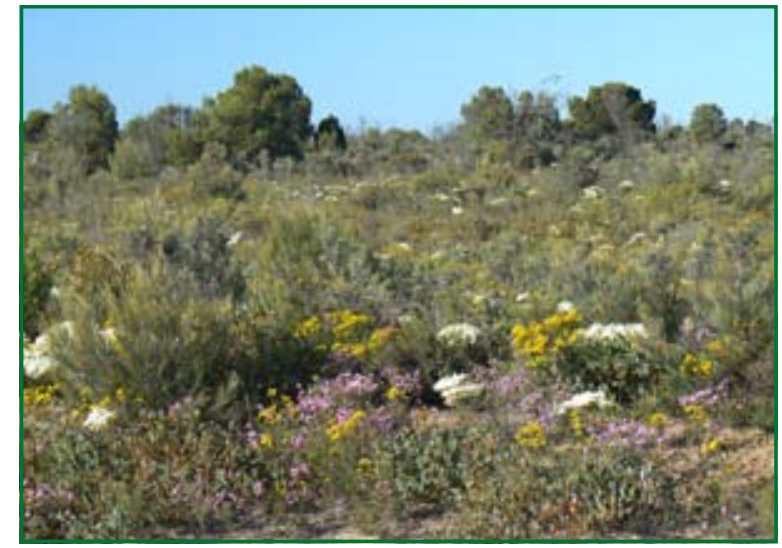

Figure 2.8.1b

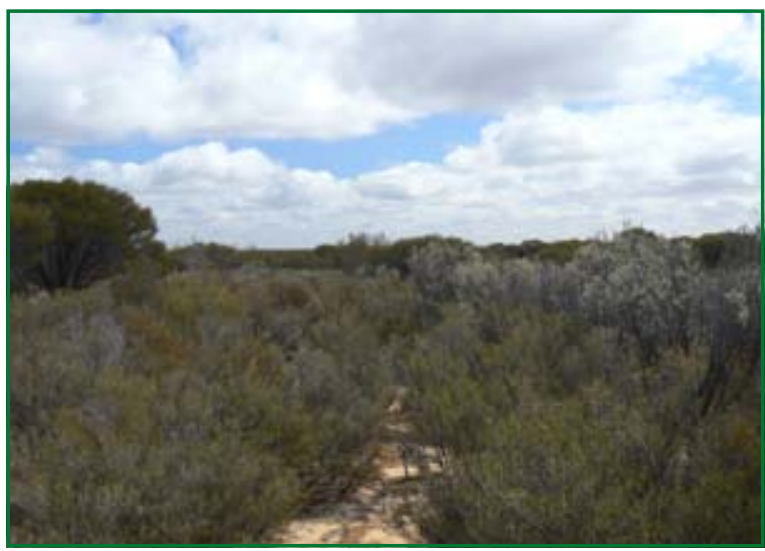

Figure 2.8.2b

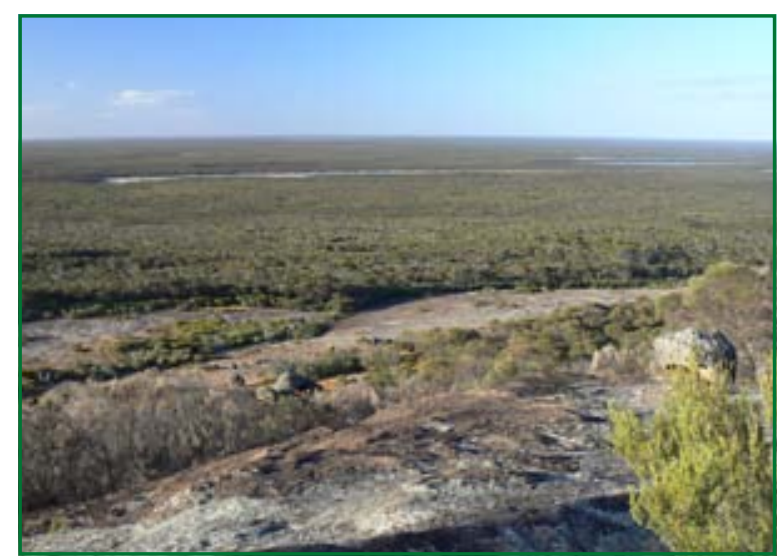

Figure 2.8.3b

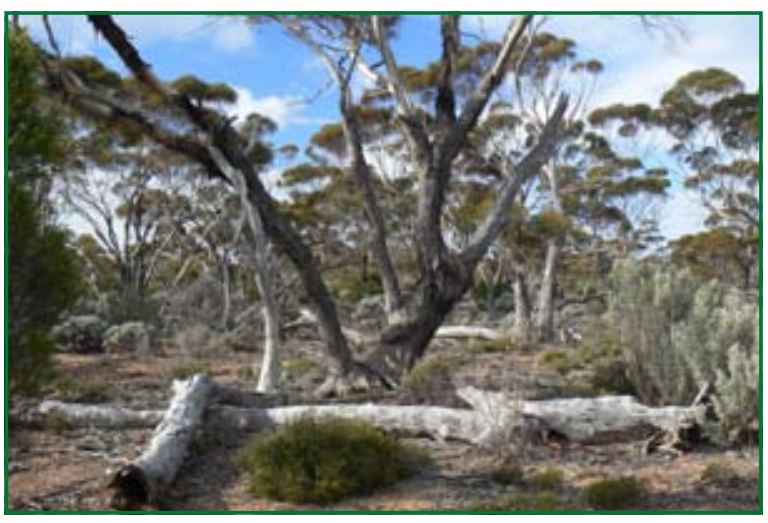

Figure 2.8.4d 


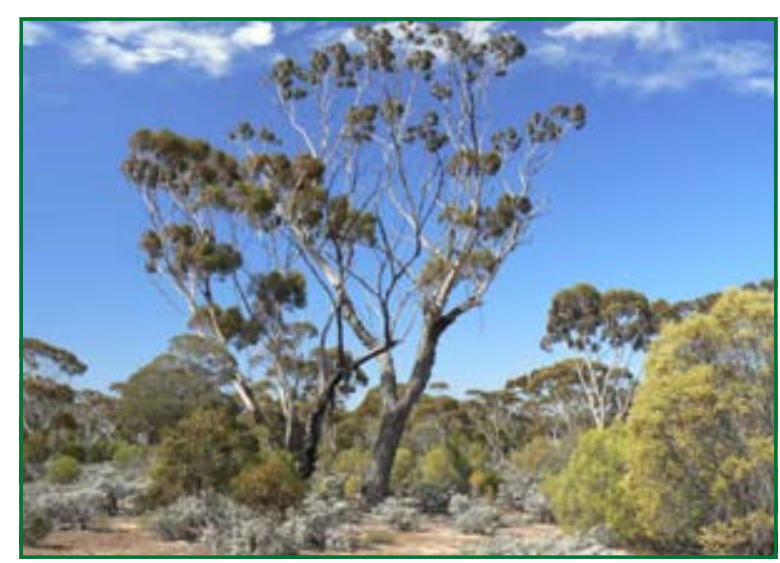

Figure 2.8.5a Sclerophyll woodlands.

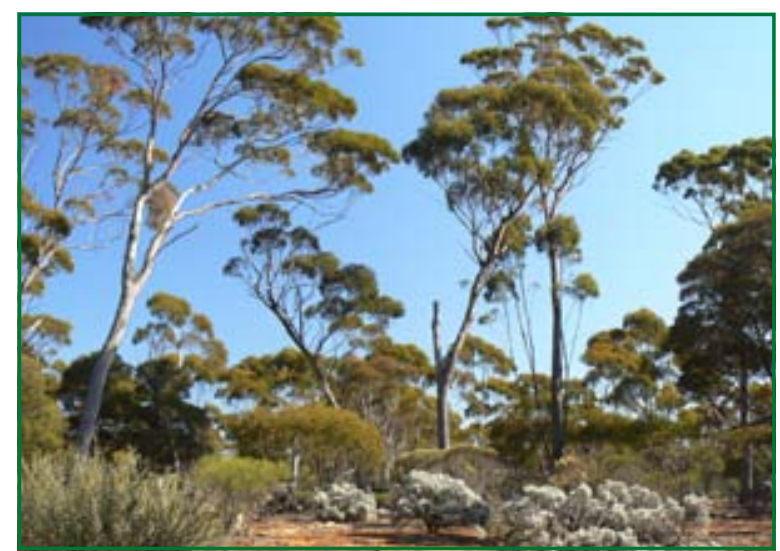

Figure 2.8.5c

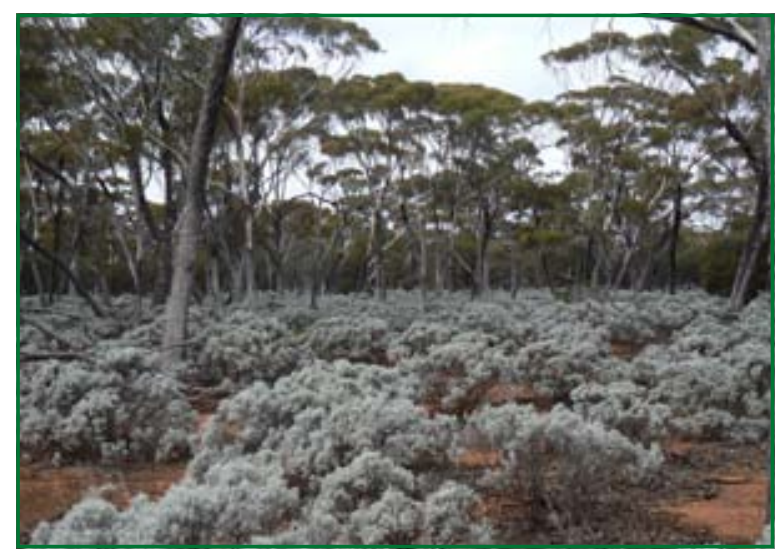

Figure 2.8.5e

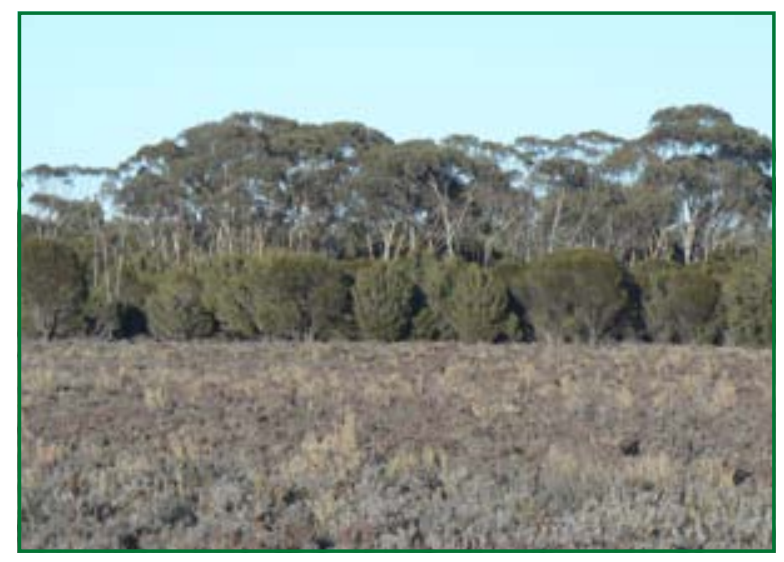

Figure 2.8.6a Halophytes.

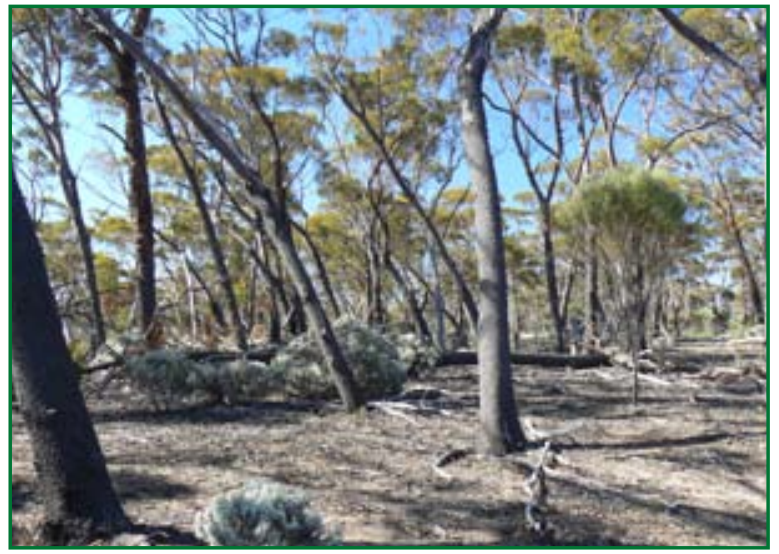

Figure 2.8.5b

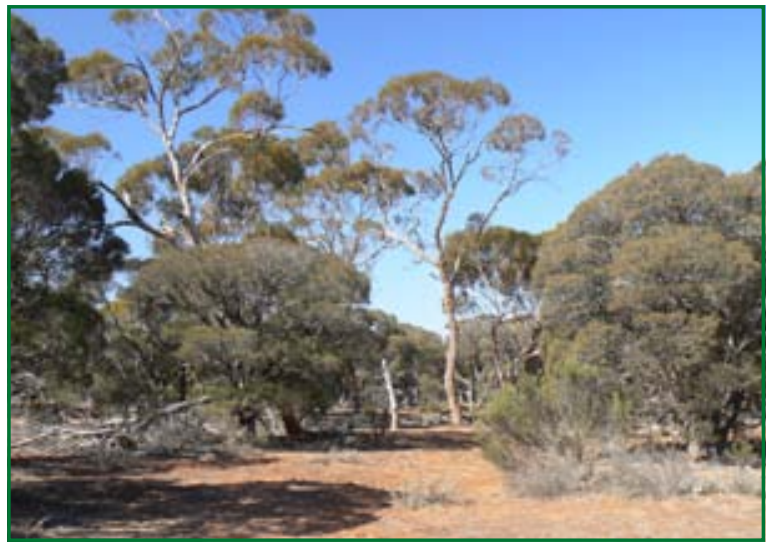

Figure 2.8.5d

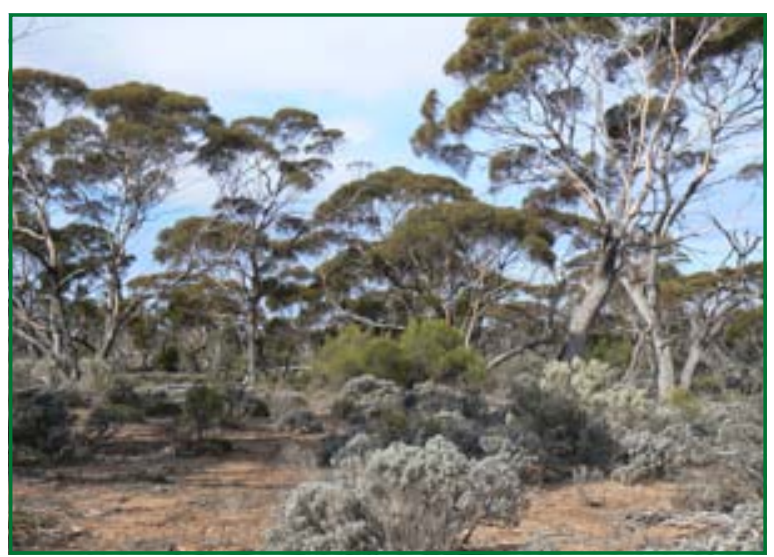

Figure 2.8.5f

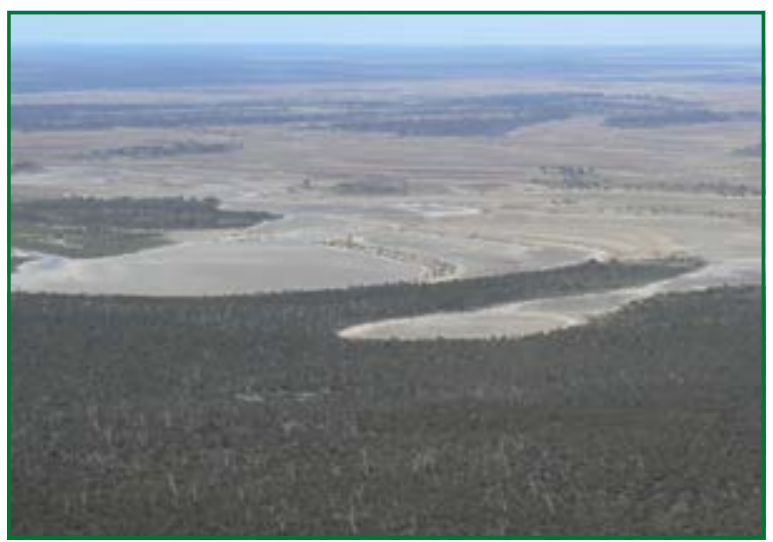

Figure 2.8.6b

Photos: S. Berry 


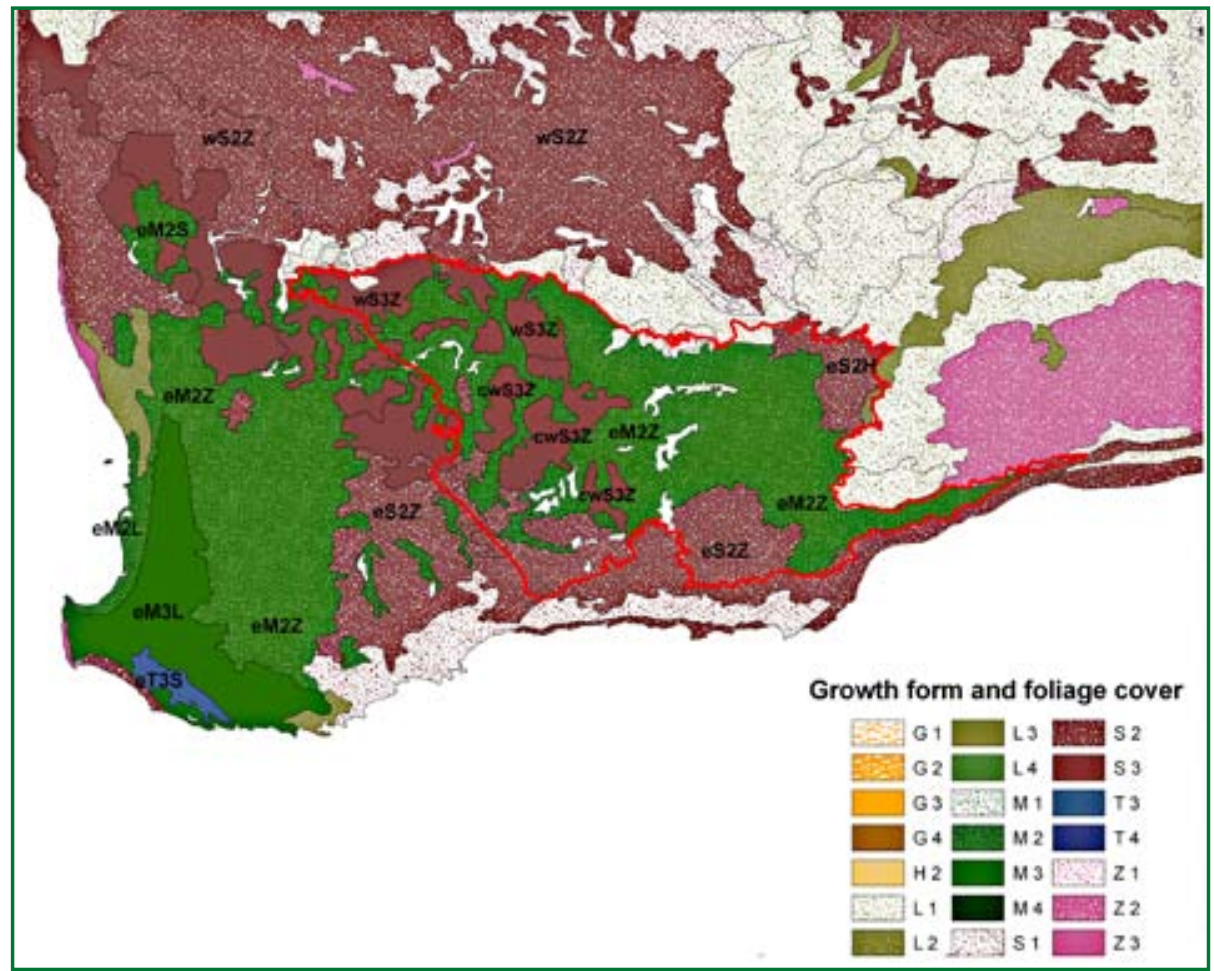

Figure 2.9a

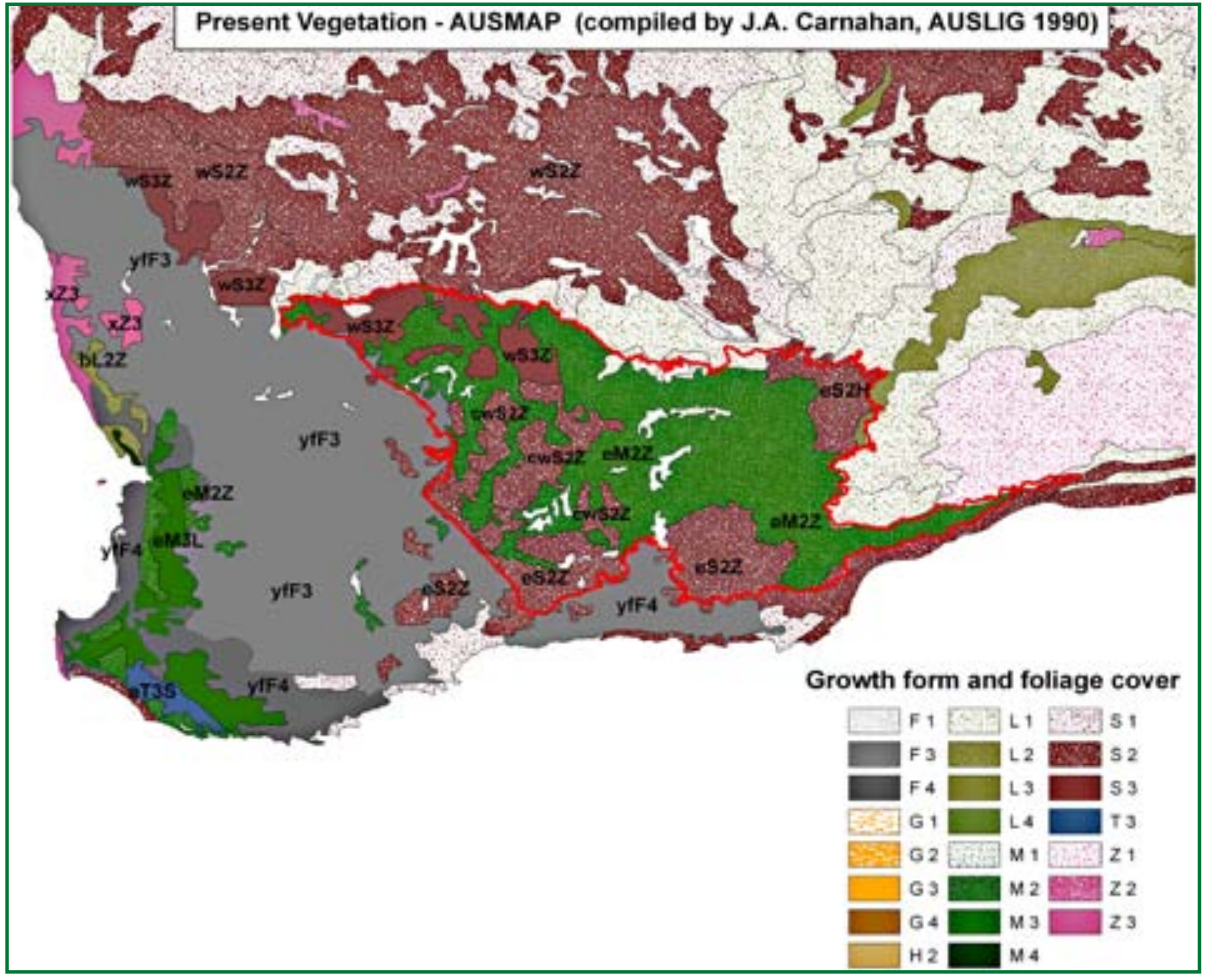

Figure 2.9b

Figure 2.9 Natural vegetation (a) and present vegetation (b) as mapped by Carnahan (AUSLIG 1990). The GWW study area is outlined in red. For growth form and foliage cover codes, see Figure 1.1. The alpha-numeric codes describe the dominant structural floristic cover. The first three (or occasionally four) characters describe the tallest stratum while the remaining character refers to the growth form of the lower stratum. The lower-case letters denote the predominant floristic type: $b=$ Banksia; $c=$ Casuarina (including Allocasuarina); $e$ = Eucalyptus; $f$ = Fabaceae (including clovers and medics); $w$ = Acacia; $x=$ mixed or other; $y=$ other grasses.

These figures incorporate natural and present vegetation data that are Copyright Commonwealth of Australia 2003. 


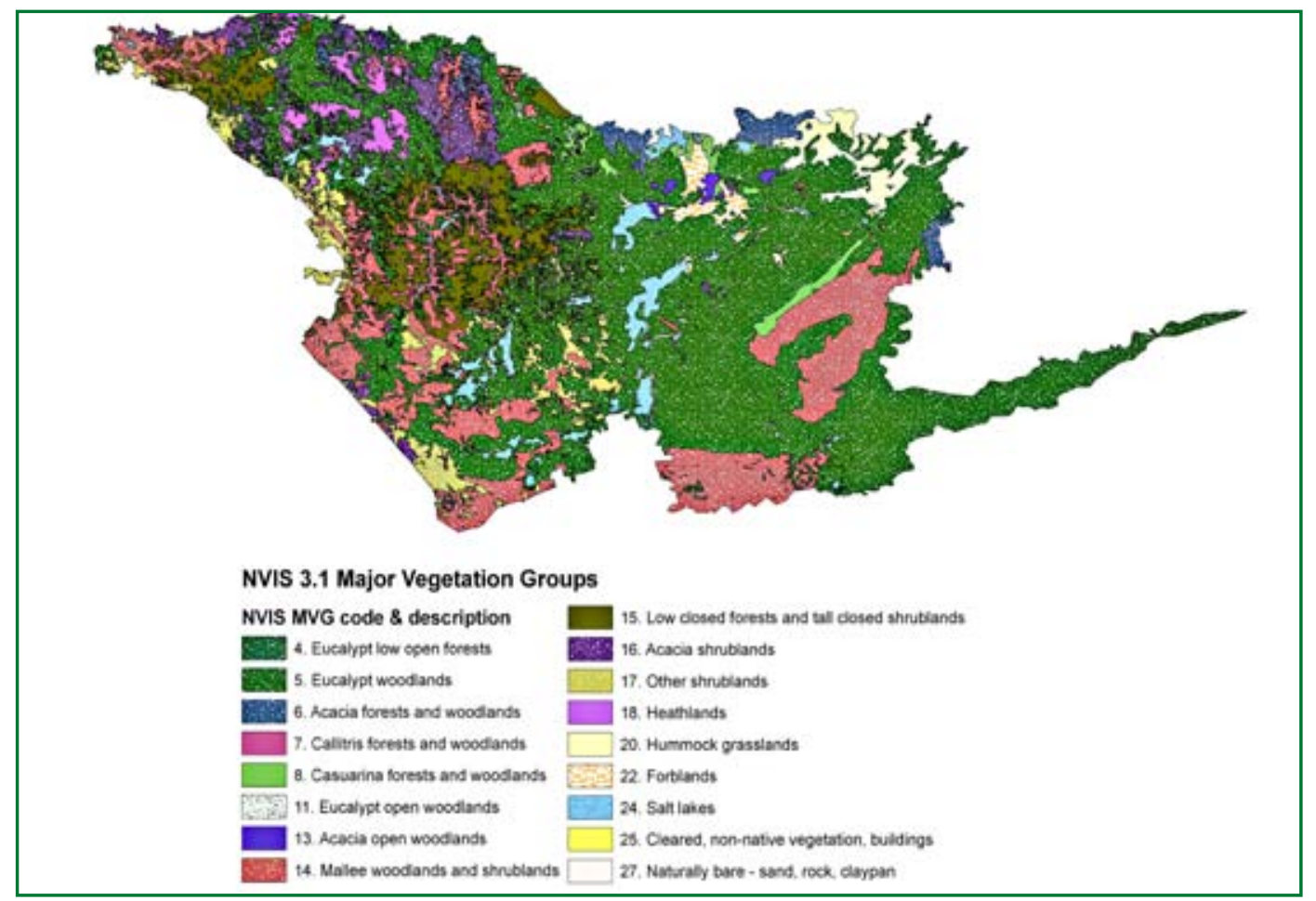

Figure 2.10 Extant vegetation cover of the GWW as mapped by NVIS 3.0 (see Table A1).

This figure incorporates NVIS Version 3.0 data that are Copyright Commonwealth of Australia 2005.

We show the relationships between the classification schemes of Carnahan, the NVIS and Beard in Table 2.1. Although the schemes all classify the vegetation according to canopy height, canopy cover and floristic association of dominant taxa, the derived classes cannot be readily equated across schemes.

Table 2.1 Relationship between the classification schemes used by Carnahan (AUSLIG 1990) shown in bold, NVIS MVGs (DEWHA 2005) and Beard (1968) shown in italics. Classes with green shading do not occur in the GWW.

\begin{tabular}{|c|c|c|c|c|c|}
\hline \multicolumn{2}{|c|}{$\begin{array}{l}\text { Canopy height } \\
\text { (m) and } \\
\text { height class }\end{array}$} & \multicolumn{4}{|c|}{ Projective foliage cover of tallest stratum (PFC; \%) } \\
\hline & & $100-70$ & $70-30$ & $30-10$ & $<10$ \\
\hline $10-30$ & $M$ & M4-closed forest & $\begin{array}{l}\text { M3-open forest } \\
M V G 3\end{array}$ & $\begin{array}{l}\text { M2-woodland } \\
\text { MVG 5, 6, 7, 8, } 14 \\
\text { Sclerophyll woodland }\end{array}$ & $\begin{array}{l}\text { M1-open } \\
\text { woodland } \\
\text { MVG 11, 14 }\end{array}$ \\
\hline $5-10$ & $\mathbf{L}$ & $\begin{array}{l}\text { L4—low closed forest } \\
\text { MVG } 15\end{array}$ & $\begin{array}{l}\text { L3-low open forest } \\
\text { MVG } 4,6,7,8,14,15 \text { ? }\end{array}$ & $\begin{array}{l}\text { L2-low woodland } \\
\text { MVG } 5,6,7,8,14\end{array}$ & $\begin{array}{l}\text { L1-low open } \\
\text { woodland } \\
\text { MVG 11, 13, } 14\end{array}$ \\
\hline $2-5$ & $S$ & $\begin{array}{l}\text { S4-closed shrub } \\
\text { MVG } 15 \text { Broombush } \\
\text { thicket Mallee }\end{array}$ & $\begin{array}{l}\text { S3-open scrub } \\
\text { MVG } 14,15 \text { ? }, 16,17,18 \\
\text { Broombush thicket Mallee }\end{array}$ & $\begin{array}{l}\text { S2-tall } \\
\text { shrubland } \\
\text { MVG } 14\end{array}$ & $\begin{array}{l}\text { S1-tall open } \\
\text { shrubland } \\
\text { MVG } 14\end{array}$ \\
\hline$<2$ & $\mathbf{Z}$ & $\begin{array}{l}\text { Z4-closed heath } \\
\text { MVG 15, } 18 \\
\text { Scrub heath }\end{array}$ & $\begin{array}{l}\text { Z3-open heath } \\
\text { MVG 16, 17, 18, } 22 \\
\text { Scrub heath }\end{array}$ & $\begin{array}{l}\text { Z2-low shrubland } \\
\text { MVG 18, } 22 \\
\text { Halophytes }\end{array}$ & $\begin{array}{l}\text { Z1-low open } \\
\text { shrubland } \\
\text { MVG 18, } 22 \\
\text { Halophytes }\end{array}$ \\
\hline$<1$ & H & & & $\begin{array}{l}\text { H2-hummock } \\
\text { grassland MVG } 20\end{array}$ & \\
\hline$<1$ & $\mathbf{F}$ & & & F2-open herbfield & $\begin{array}{l}\text { F1-sparse } \\
\text { open herbfield } \\
\text { Rock pavement } \\
\text { vegetation }\end{array}$ \\
\hline
\end{tabular}


Table 2.2 Areal extent of cover of NVIS Major Vegetation Groups (version 3.0) in the GWW.

\begin{tabular}{l|c}
\multicolumn{1}{c}{ Major vegetation group } & $\begin{array}{c}\text { Area } \\
\text { 4. Eucalypt low open woodlands }\end{array}$ \\
\hline 5. Eucalypt woodlands & 4.4 \\
\hline 6. Acacia forests and woodlands & $\mathbf{8 3 7 7 . 1}$ \\
\hline 7. Callitris forests and woodlands & 299.7 \\
\hline 8. Casuarina forests and woodlands & $\mathbf{4 . 6}$ \\
\hline 11. Eucalypt open woodlands & 227.9 \\
\hline 13. Acacia open woodlands & 15.5 \\
\hline 14. Mallee woodlands and shrublands & 64.2 \\
\hline 15. Low closed forests and tall closed shrublands & 2748.3 \\
\hline 16. Acacia shrublands & 1048.7 \\
\hline 17. Other shrublands & 748.6 \\
\hline 18. Heathlands & 527.8 \\
\hline 20. Hummock grasslands & 304.4 \\
\hline 22. Forblands & 332.4 \\
\hline 24. Salt lakes & 227.3 \\
\hline 25. Cleared, non-native vegetation, buildings & 616.4 \\
\hline 27. Naturally bare-sand, rock, claypan, mudflat & 222.1 \\
\hline Total native vegetation cover & 202.4 \\
\hline Total area of GWW & 14931.0 \\
\hline
\end{tabular}

\subsection{TIMBER CUTTING IN THE GWW}

The timber resource of the GWW was pivotal to the development of the Eastern Goldfields. Between 1897 and 1969, the woodlands were cut to provide 22 million tonnes of timber and fuel wood for the mines of the Golden Mile (Kalgoorlie region), mostly to fuel the boilers to power mining machinery (Figures 2.11-2.13) (Western Australia Forests Department 1969). Additionally, the woodlands were exploited to provide timber and fuel wood to the Norseman goldfields, 2.2 million railway sleepers, 3.4 million fence posts, 84000 bean sticks and 110000 posts, poles and bridge timbers (Western Australia Forests Department 1934-70). Salmon gum (Eucalyptus salmonifloia) and gimlet (Eucalyptus salubris) were the preferred species for timber cutting in the GWW. 'Woodlines' -railway lines-were constructed to transport the timber to the mines in Kalgoorlie. Wood was also cut to fuel-continuously for 55 years - the six pumping stations of the Goldfields Water Supply Scheme between Cunderdin and Coolgardie. Approximately onequarter of the GWW (4.4 million ha; see Table 2.3) was cut over (estimated from the map shown in Figure 2.12), producing, on average, 10 tonnes of firewood per cut-over hectare (Western Australia Forests Department 1969). These figures indicate that the total eucalypt timber harvest could have been about 40 million tonnes. Sandalwood was also cut to provide raw materials for the production of incense, soap and perfumes (Western Australia Forests Department 1934-70). 


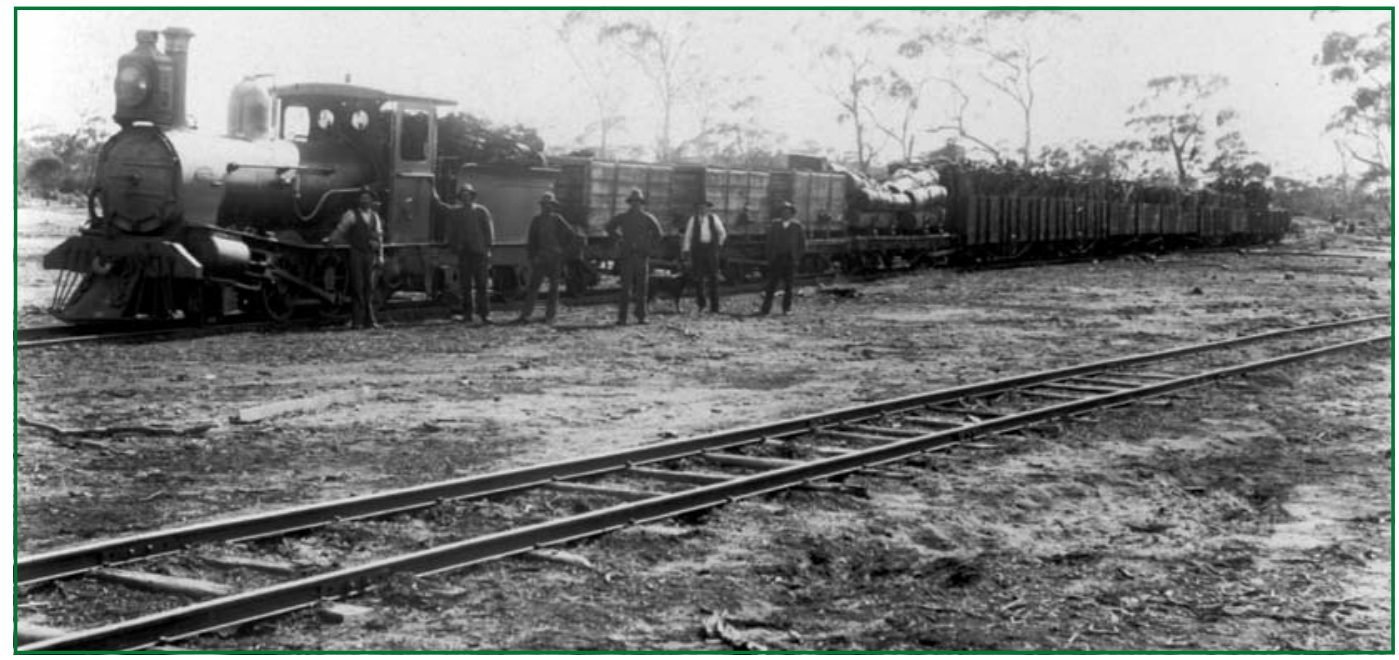

Figure 2.11a

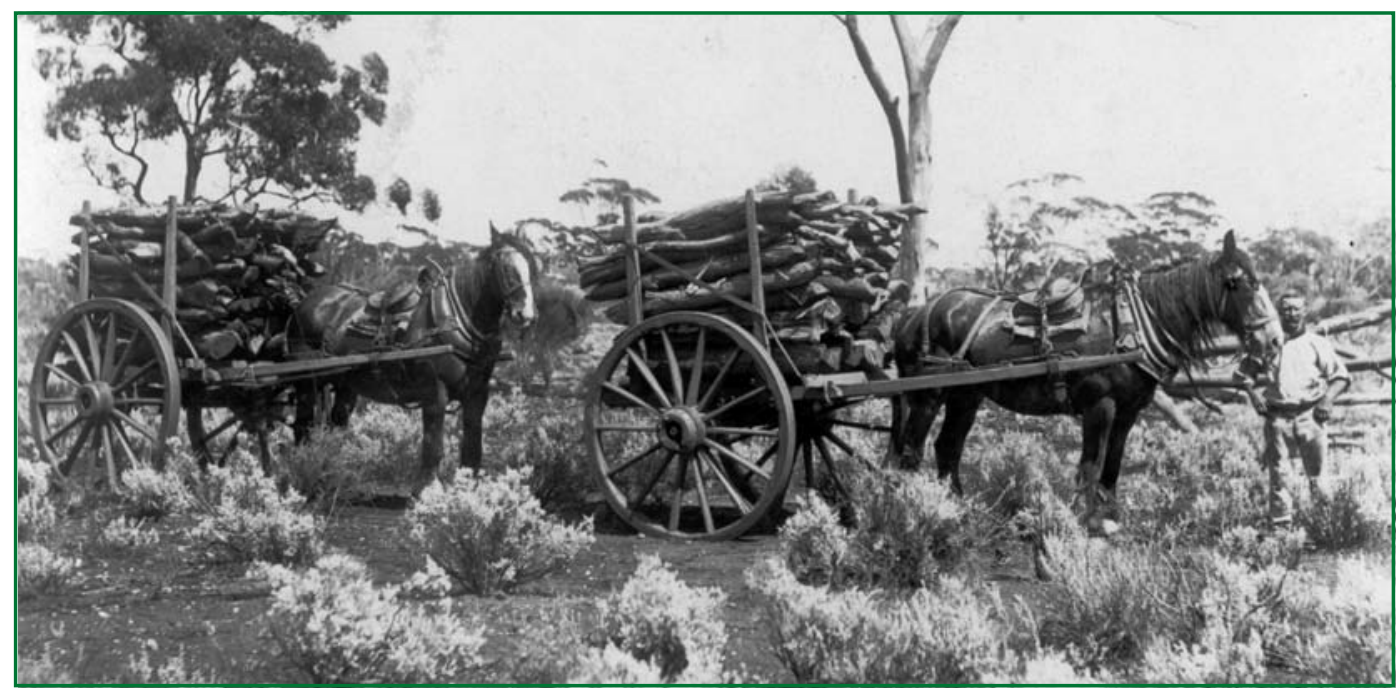

Figure $2.11 \mathrm{~b}$

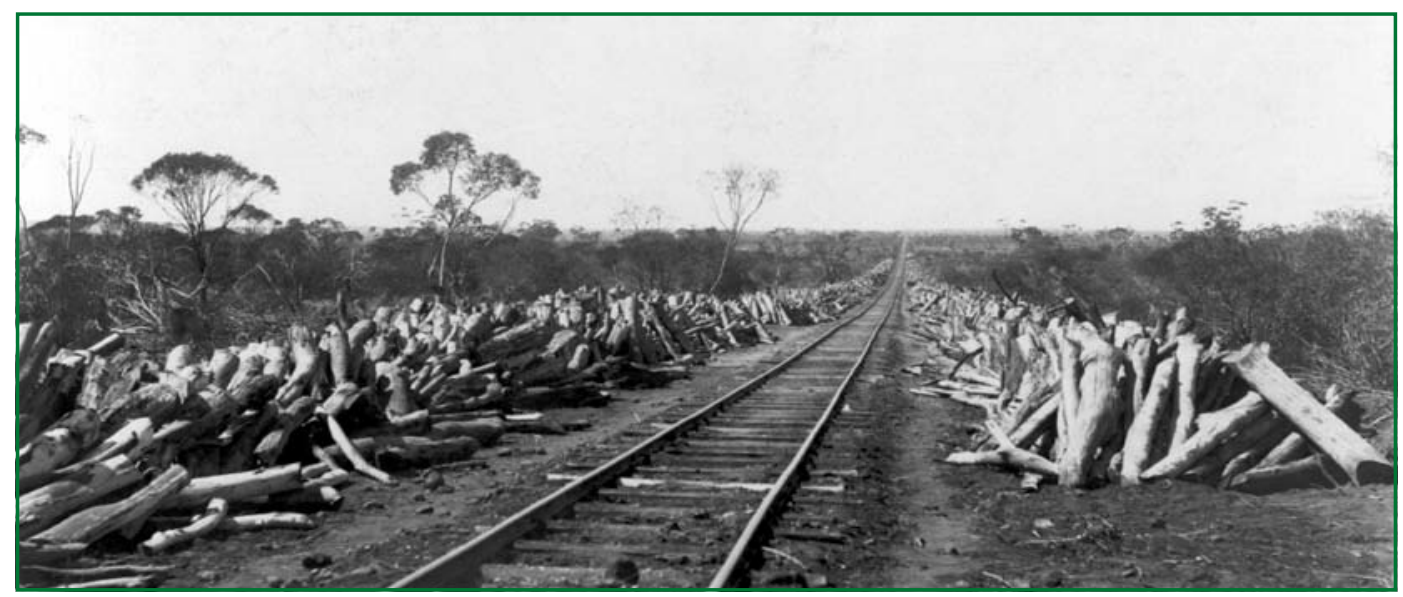

Figure 2.11c

Figures 2.11 Timber cutting in the GWW was carried out principally by the Kalgoorlie Boulder Firewood Company. Train loaded with logs (a); Horse-drawn carts stacked with wood, 1910. (b); and logs stacked by the woodline (c).

Photos reproduced by permission of The Battye Library, State Library of Western Australia (image reference numbers: 005703D, 005705D, 005708D). 


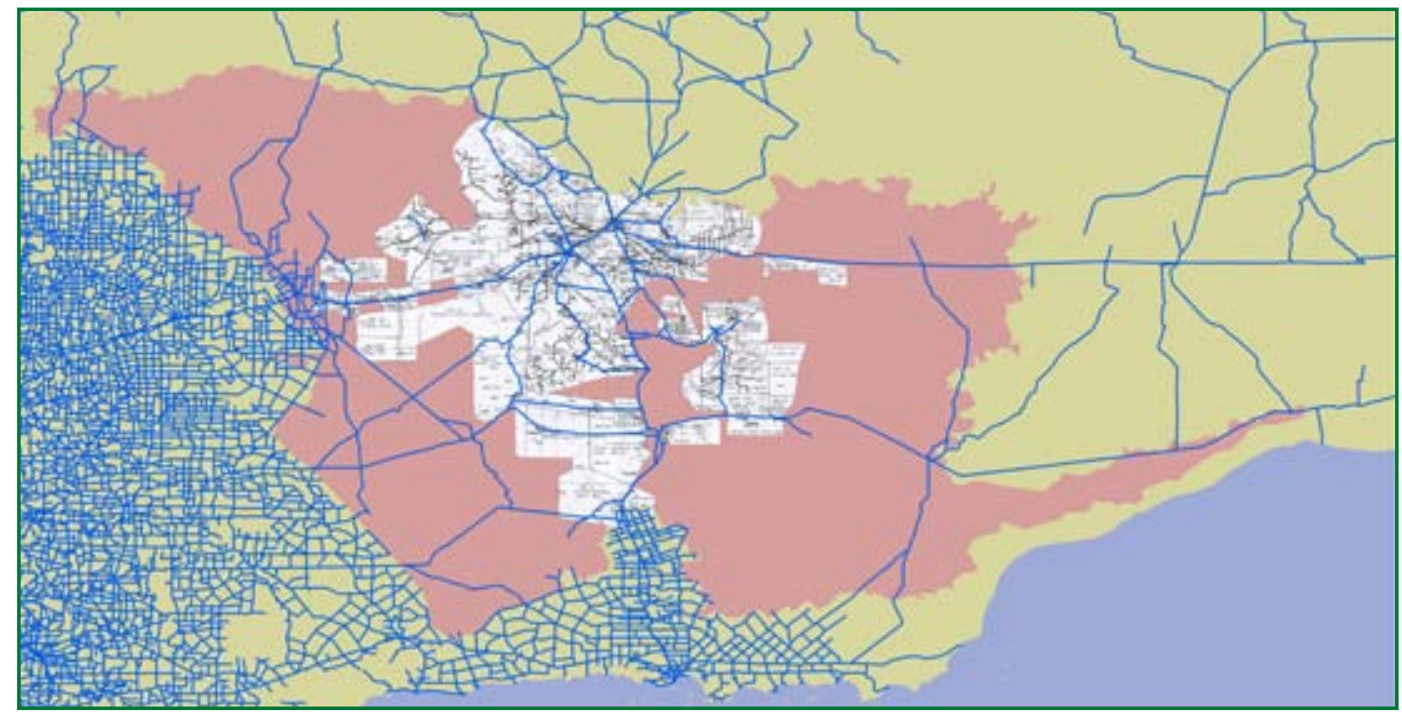

Figure 2.12 Map showing the extent of timber cutting in the GWW. The area within the GWW that was not subjected to timber cutting is coloured pink. The timber-cut area is shown as a transparent overlay over the 1:50 000 scale map 'Timber tramlines and cutting areas in the Goldfields Region 1900-1975' (FD No. 1610, 1978), which identifies the location of woodlines and coupe boundaries. Roads (see Table A1) are shown as blue lines.

This figure incorporates road location data that are Copyright State of Western Australia 2007.

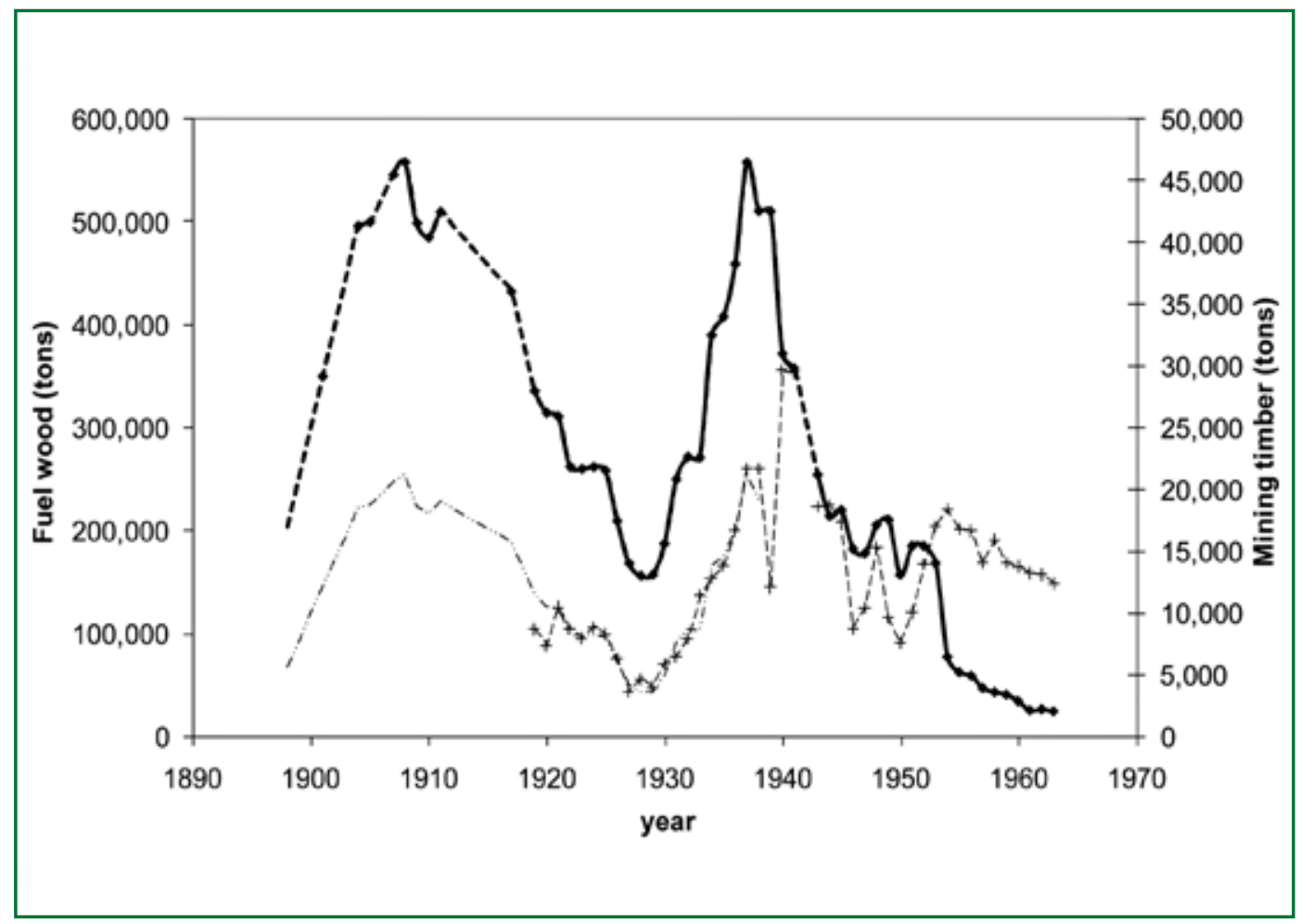

Figure 2.13 Timber harvested (tons) for fuel wood and mining from public land in the Eastern Goldfields in the period 1898-1963. Data from Forests Department reports are shown in solid lines with black diamonds (fuel wood) and dashed lines with ' + ' (mining timber). To estimate the total harvest of fuel wood, a linear interpolation between the reported values was used (shown by the dashed line). Before 1938, there is a linear relationship between fuel wood and mining timber ( mining $=0.0438$; fuel wood $=3245.8 ; R^{2}=0.92$ ) and this is used to estimate the mining timber consumption pre-1939 (also shown as dashed line). Note: 1 ton is equivalent to 1.016 tonne.

Data from Forests Department reports compiled by Bianchi et al. (2008). 
Table 2.3 Area within current (1993) land tenure types that was utilised for fuel wood and mining timber between 1900 and 1975 .

\begin{tabular}{|c|c|c|}
\hline Land tenure type & $\begin{array}{c}\text { Estimated area affected by timber } \\
\text { cutting between } 1900 \text { and } 1975 \\
(\text { ha } \times 1000)\end{array}$ & $\begin{array}{c}\text { Total area } \\
(\text { ha } \times 1000)\end{array}$ \\
\hline 1. Aboriginal reserve & 0 & 108 \\
\hline 2. Aboriginal leasehold & 22 & 252 \\
\hline 3. Forestry reserve & 38 & 120 \\
\hline 4. Other freehold & 10 & 249 \\
\hline 5. Other leasehold & 1598 & 3513 \\
\hline 6. Mixed & 9 & 9 \\
\hline 7. Nature conservation reserve & 155 & 1651 \\
\hline 8. Other & 91 & 160 \\
\hline 9. Vacant crown land & 2402 & 9859 \\
\hline 10. Water reserve & 42 & 44 \\
\hline Total & 4367 & 15965 \\
\hline
\end{tabular}

Spatial data sources for calculations: see Table Al—Land tenure, timbercutting.

\subsection{OVERVIEW OF ANTHROPOGENIC IMPACTS IN THE GWW}

With the exception of the freehold land (cleared for cropping) on the western boundary, the GWW retains a cover of native vegetation. About half of the GWW, however, has been subjected to direct anthropogenic impacts of mineral exploration and mining, timber cutting and pastoralism (Figure 2.14) that have resulted in the thinning or removal of biomass. As discussed in Chapter 3, a consequence of these impacts is that the current carbon stock will be below the natural carbon carrying capacity. In Chapter 3, we also quantify the extent of another major agent of disturbance in the GWW: recent intense wildfire. 


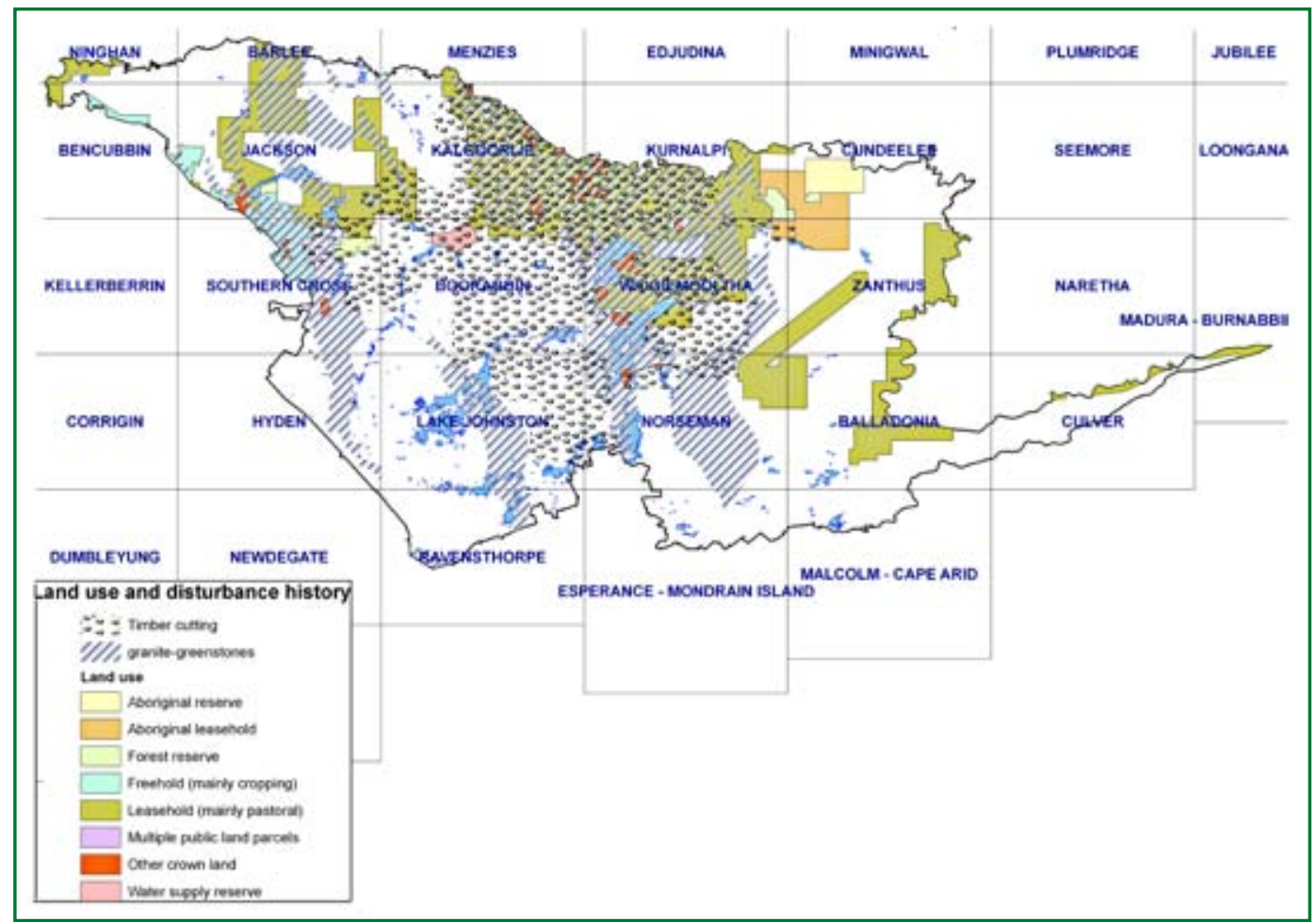

Figure 2.14 Map showing area affected by timber cutting, mining and mineral exploration (indicated by the granite-greenstone lithology) and land-use change in the GWW. The index of 1:250 000 geological series map sheets is shown as an overlay.

Reference: see Table A1-Map Sheet, Land Tenure, Lithology and Table A2. This figure incorporates Australian land tenure (1993) data that are Copyright Commonwealth of Australia 1993, and map sheet Index250 and geology data that are Copyright State of Western Australia 2007.

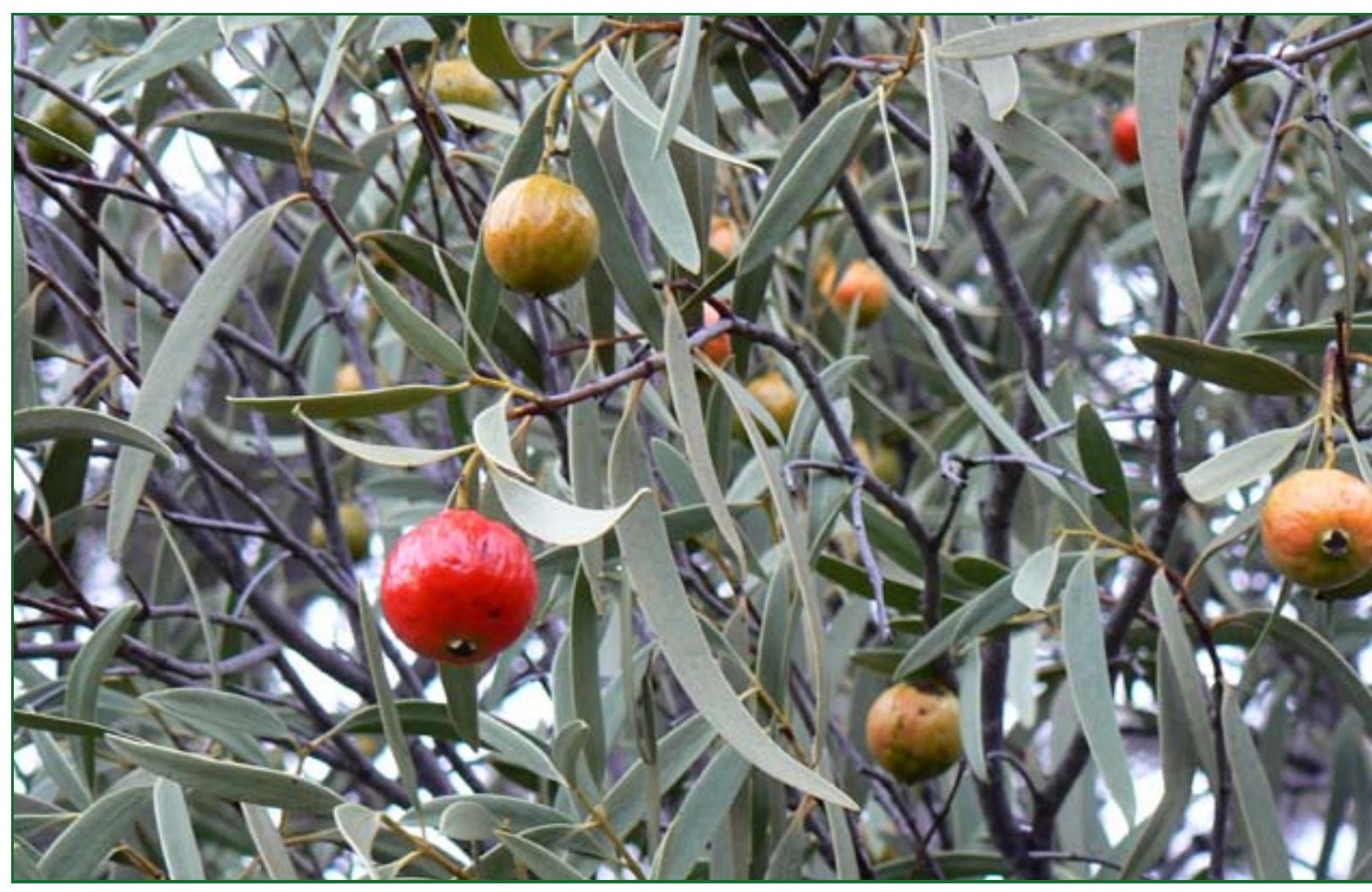




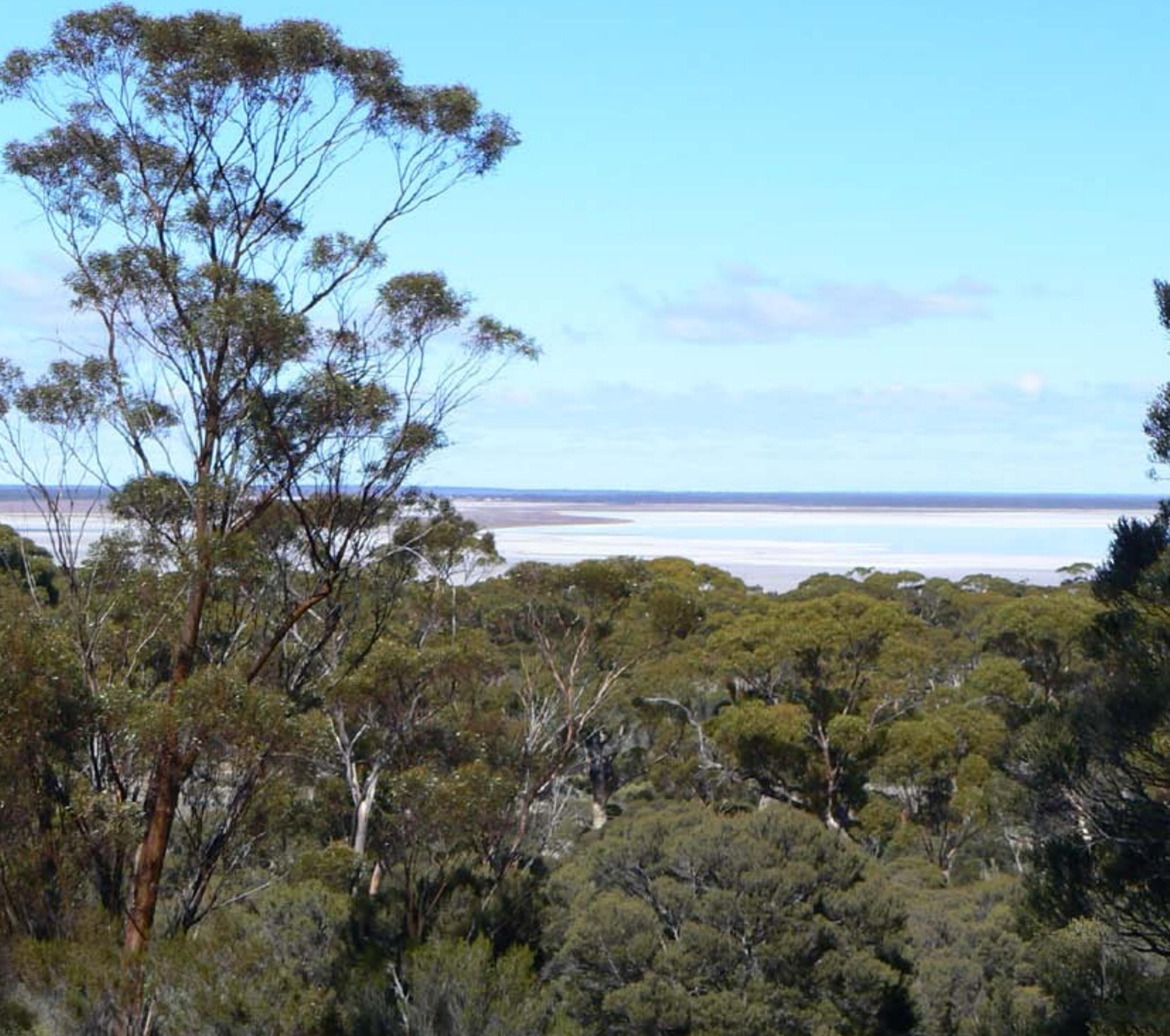

3046

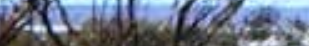 \\ (1)}

m.340

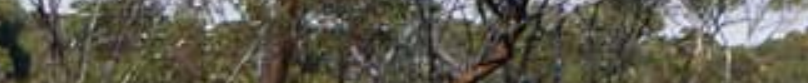

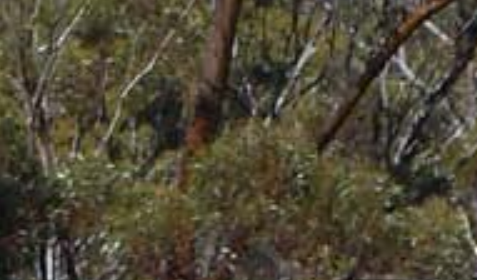

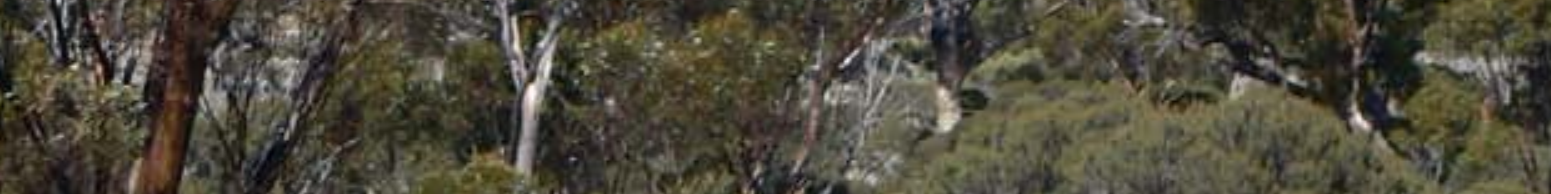

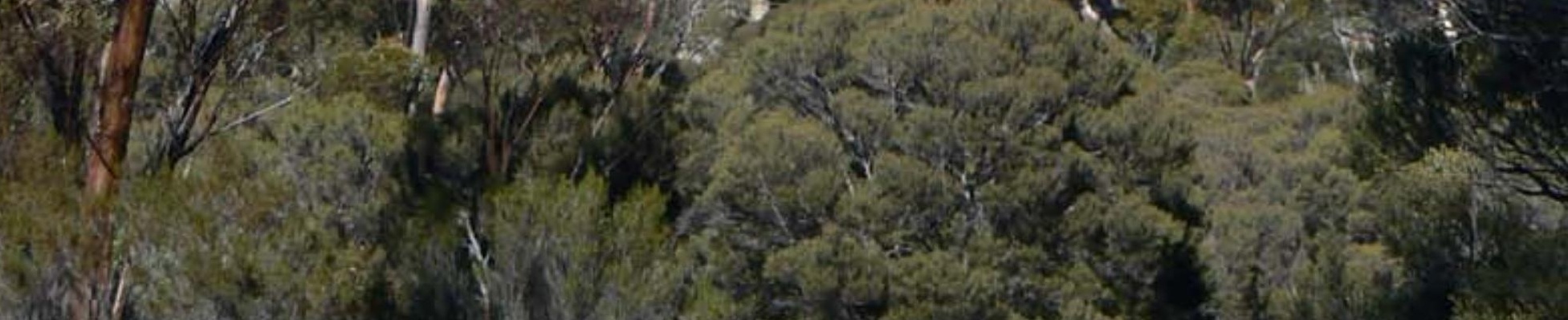

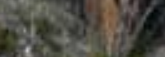

2 a.r.x-2

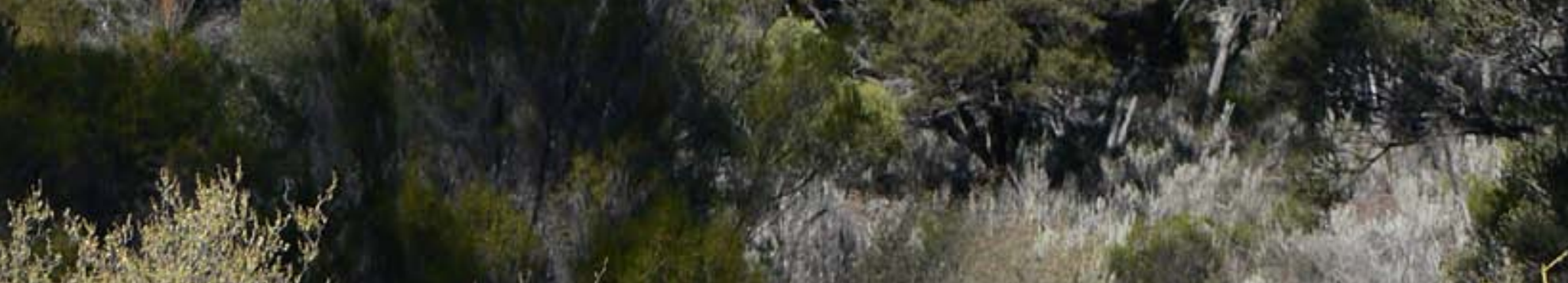

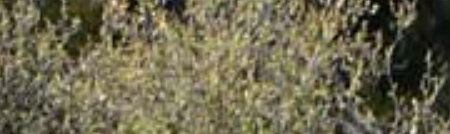

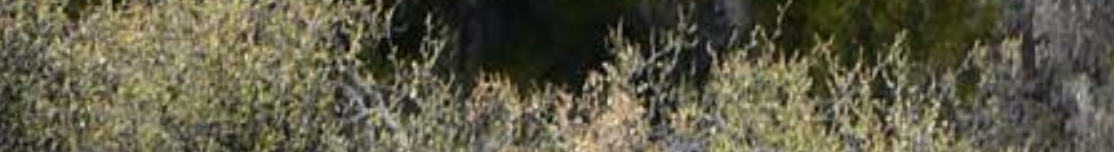
64.

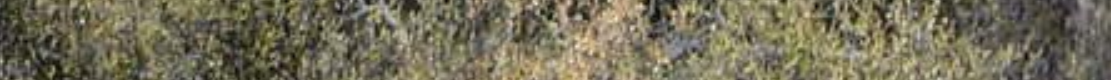

1.).

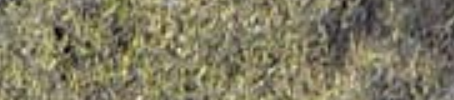

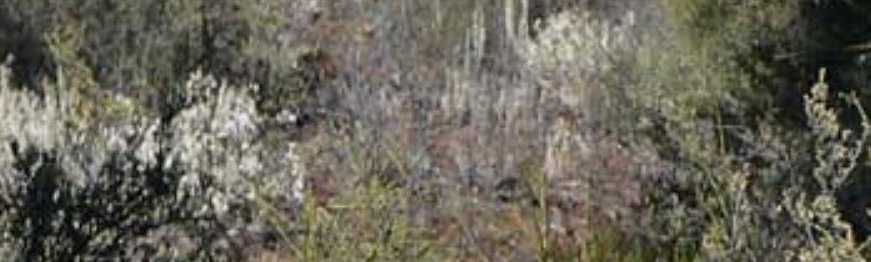

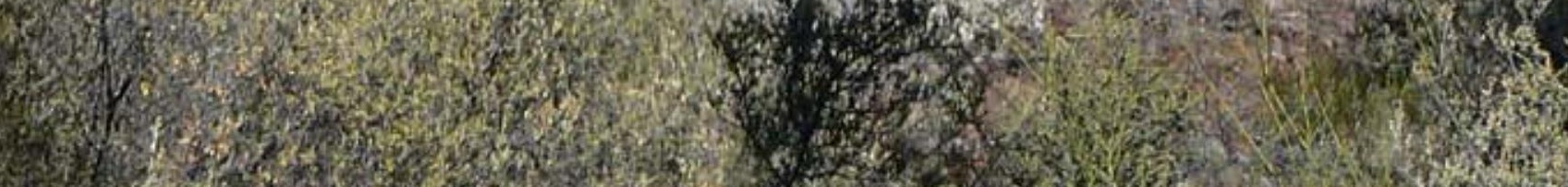

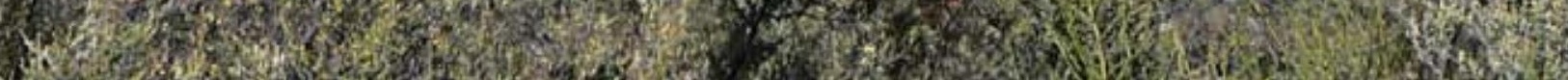




\section{METHODS TO CALCULATE CARBON STOCKS}

Two groups of data were used to develop a model of carbon stocks-namely: 1) site-specific measurements obtained through field survey; and 2) spatial data layers derived from GIS, remote sensing and environmental modelling. Site-specific data include inventory plots with measurements of the number and dimensions of plants (usually stem diameter and height) within a defined area. Allometric equations were used to estimate biomass from the measurements of plant dimensions. To extrapolate carbon stocks calculated from site-specific measurements to other locations requires spatial data layers that describe the spatial variation in environmental factors that influence biomass. These data layers (see Table Al) describe the vegetation, climate, geology and land-use history factors of mining exploration, timber cutting and wildfire occurrence. Correlations in variation of the spatial environmental factors and biomass at the field sites form the algorithms used in the extrapolation model of carbon stocks.

\subsection{SITE-SPECIFIC DATA}

\subsubsection{Field data}

ANU researchers obtained site inventory data of trees and shrubs during three field surveys from 2005 to 2007. Data were obtained for 21 sites of $250 \mathrm{~m} \times 250 \mathrm{~m}$ in area (6.25 ha). The large sites were used: 1) to obtain representative measurements of tree and shrub size distributions in heterogeneous communities; and 2) to correspond to the pixel size of remote sensing imagery, and thus reduce the errors associated with up-scaling from small plots to pixels. Sites were marked out such that the vegetation within the boundaries was as homogeneous as possible. Site locations are shown in Figure 3.1.

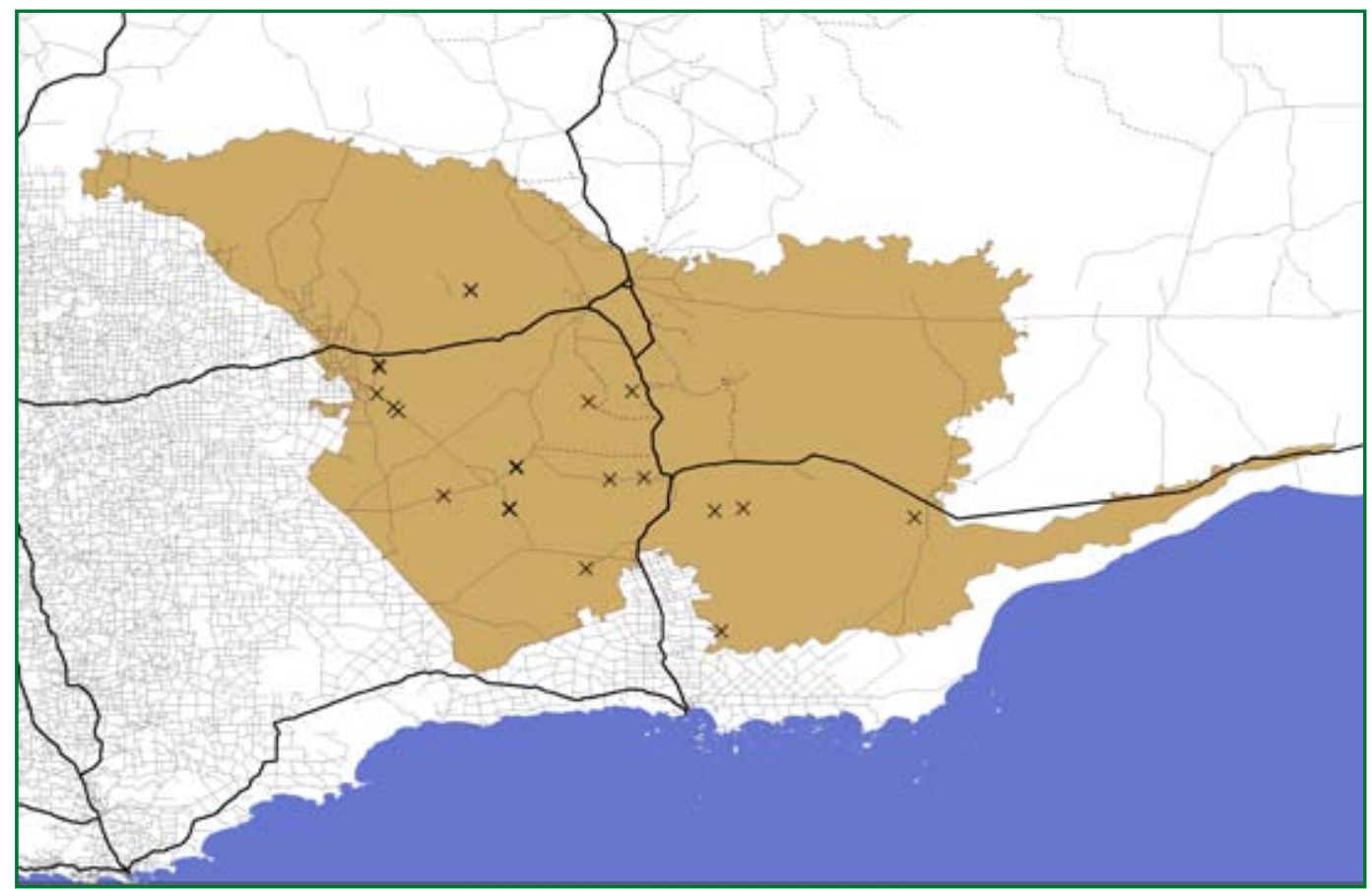

Figure 3.1 Map of the GWW showing the location of the 21 field survey sites (indicated byx). Roads (see Table A1) are shown as black lines.

This figure incorporates road location data that are copyright State of Western Australia 2007. 
At each site, the major canopy layers were identified-namely: 1) monopodial or single-stemmed trees with up to three canopy layers; 2) mallee or multi-stemmed lowtree layer; 3) tall shrub layer; 4) saltbush/bluebush low shrub layer; 5) mallee shrub layer; and 6) sclerophyllous (heath) shrub layer. A Point Centred Quarter (PCQ) method was used for sampling (see Bonham 1989; Tongway and Hindley 2004). Within sites, 16 point centres were located using a grid, as shown in Figure 3.2. Measurements were made within a $25 \mathrm{~m}$ radius of each point centre. Within each of the four quarters surrounding a point centre, the distance was measured to the nearest stem within each canopy layer (Figure 3.3). Plant dimensions of stem diameter at $1.3 \mathrm{~m}$ height (corresponding to diameter at breast height, $\mathrm{dbh}$ ) for the tree canopy layer and plant height for all canopy layers were also measured. Absolute density of plants within each canopy layer (units: stems $\mathrm{ha}^{-1}$ ) was calculated from the number of observations and distance (see Mitchell 2007; Warde and Petranka 1981). The field data and calculations are summarised in the Appendix and Table A5.

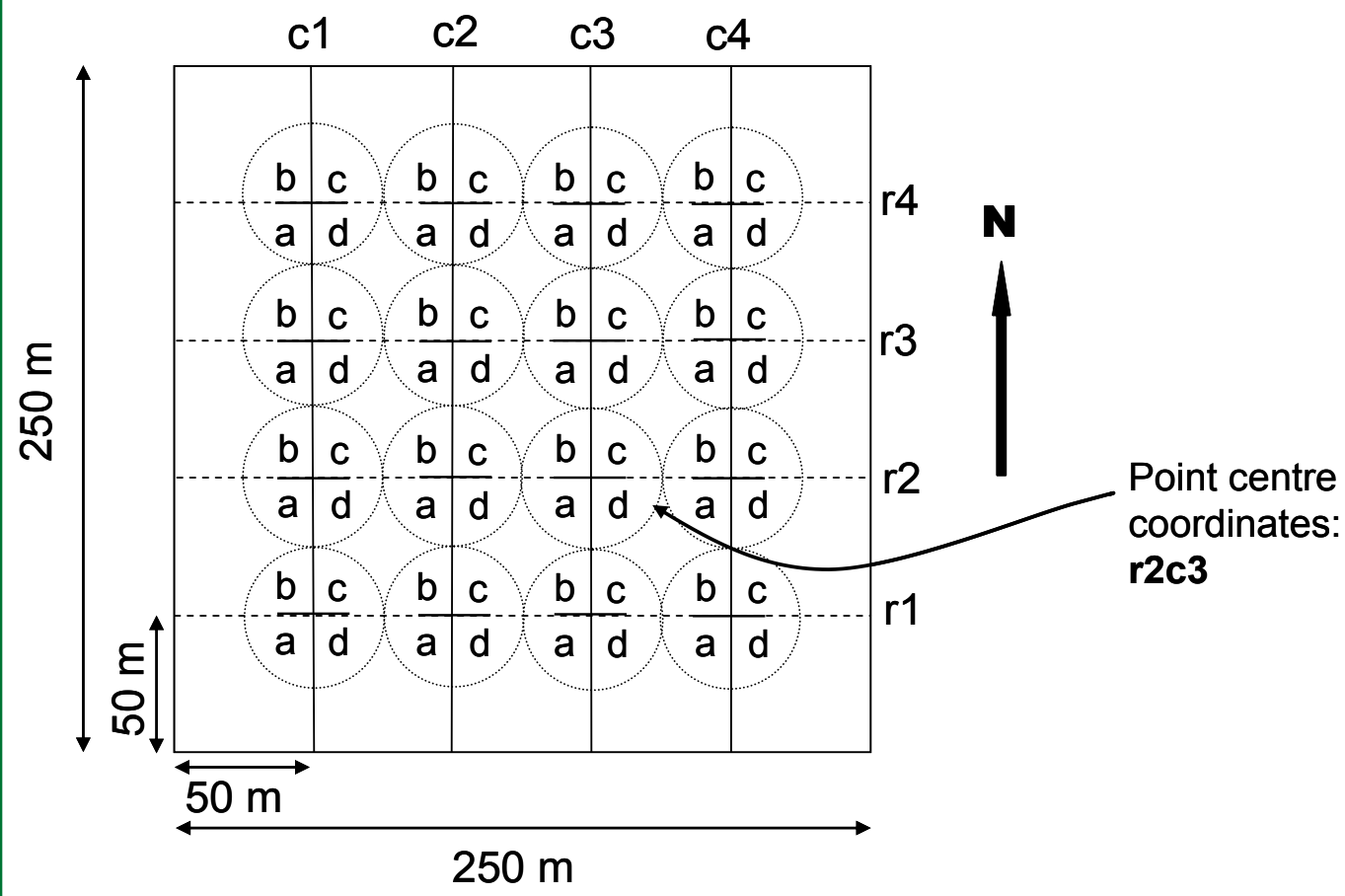

Figure 3.2 Location of the 16 point centres within a study site. 


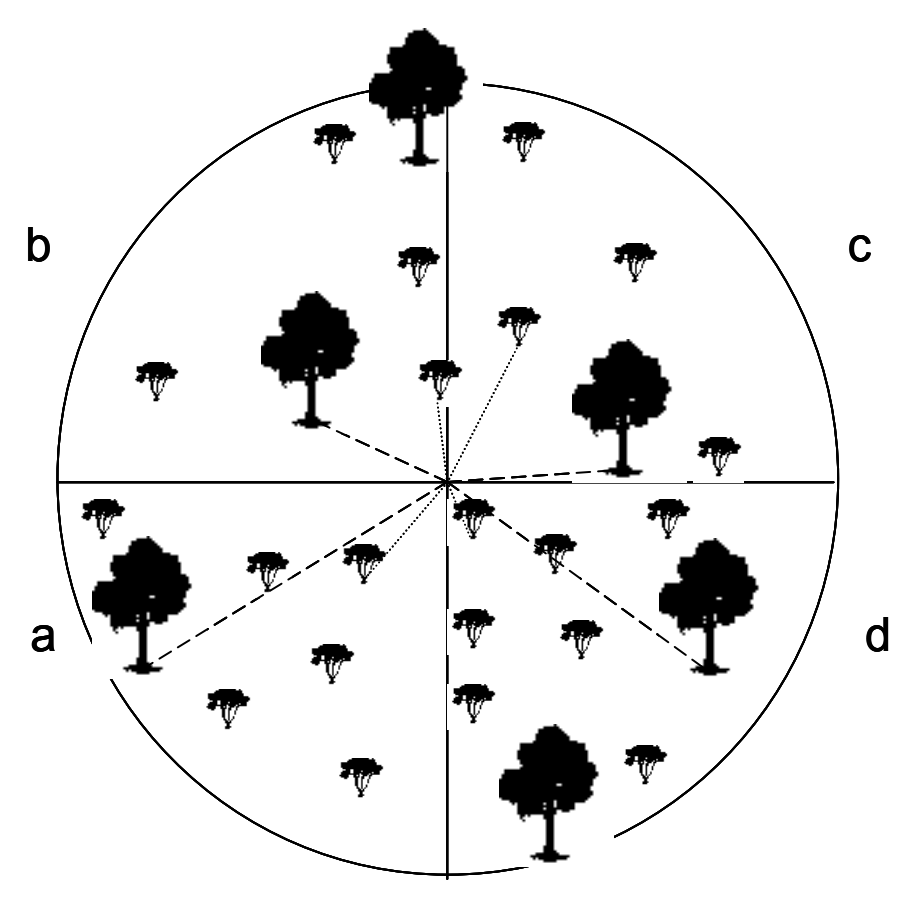

Figure 3.3 The PCQ method for measurement within each quarter (a-d) is shown as the distance from the point centre to the nearest stem of each canopy layer. Two canopy layers are shown in this example.

\subsubsection{Allometric equations}

Allometric equations relate tree dimensions to biomass and are derived using data from trees that were destructively sampled and the biomass components weighed. Allometric relationships describe plant morphology and vary in relation to site environmental conditions and plant genetics. Allometric equations do not exist for the species within the GWW. Hence, we compared allometric equations developed for species elsewhere in Australian woodlands to assess their utility for biomass estimation for tree and shrub canopy layers in the GWW.

A compilation of allometric equations derived for woodland species in Australia is attached in the Appendix (Table A6). Additionally, we had access to more recently derived equations for some woodland trees and mallees in south-western Western Australia (J. Jonson unpublished; see Table A7). Here, we present comparisons of predicted above-ground biomass (AGB) for eucalypt trees using generalised equations. We tested these equations using our inventory data that have a tree diameter at breast height (dbh) ranging from 2 to $118 \mathrm{~cm}$. The allometric equations can be subdivided into two groups: those that require inputs of 1) stem diameter or basal area, and 2) stem diameter and stem height. An assumption of (1) is that there is a consistent relationship between stem diameter and stem height. The following are the main allometric equations for woodland trees in Australia.

Burrows et al. (2000) measured biomass of stands of Eucalyptus crebra, E. melanophloia and E. populnea in central Queensland rangelands. They derived the general relationship (Equation 3.1). 


\section{Equation 3.1}

$A G B=6.51 B-6.65\left(\dagger^{h a^{-1}}\right)$

In Equation 3.1, B is the stand basal area $\left(\mathrm{m}^{2} \mathrm{ha}^{-1}\right.$ ) (derived from diameter at $1.3 \mathrm{~m}$ height; dbh range $1.5-76.4 \mathrm{~cm}$ ). This equation yields negative values of $A G B$ for sites where the stand basal area is less than $1.0215 \mathrm{~m}^{2} \mathrm{ha}^{-1}$. This problem can be circumvented by forcing the regression through zero using the simplified Equation 3.2.

\section{Equation 3.2}

$A G B=6.10 B\left(t h a^{-1}\right)$

Estimated site biomass of the tree canopy layer, based on Equations 3.1 and 3.2, is presented in Table 3.1. Using these equations, it is assumed that $A G B$ is linearly related to stem basal area-that is, that stem height $\times$ wood basic density has a constant value $\left(6.1 \mathrm{tha}^{-1}\right)$. It is, however, difficult to account for tree damage that is common in natural stands-for example, due to fire and wind—using a simplified linear relationship.

For individual Eucalyptus melanophloia (silver-leaved ironbark) sampled at two sites (380 km distant) in central Queensland, Burrows et al. (2001) derived Equation 3.3.

\section{Equation 3.3}

$\ln (A G B)=2.700 \ln C-6.434\left(\mathrm{~kg} \mathrm{tree}^{-1}\right)$

In Equation 3.3, $C$ is the stem circumference at $30 \mathrm{~cm}$ above ground (dbh range 1.9$52.5 \mathrm{~cm}$ ). The basic density ${ }^{6}$ of this species is $\sim 1080 \mathrm{~kg} \mathrm{~m}^{-3}$ (Boland et al. 1984:532) - a value similar to the basic density expected for GWW eucalypts.

For mallee eucalypts (Eucalyptus socialis/E. dumosa combined), at the location 33⒌' 1463' $\mathrm{E}$ (dbh range 2.5-55.2 cm), Burrows et al. (see Eamus et al. 2000 and Table A6.1) derived Equation 3.4.

\section{Equation 3.4}

$\ln (A G B)=2.262 \ln C-4.1671\left(\mathrm{~kg}\right.$ tree $\left.{ }^{-1}\right)$

The general equation developed by Jonson (unpublished) for eucalypt woodland species (dbh range 2.3-79 cm) in the wheatbelt of south-western Western Australia (see Table A7) has the same form as Equations 3.3 and 3.4. The equation of Jonson, however, predicts AGB up to $\sim 20$ per cent smaller than Equations 3.3 and 3.4 (Figure 3.4) for the maximum stem dbh measured at our field sites.

Williams et al. (2005) have derived a general allometric equation for estimating AGB of trees (mostly eucalypts) in tropical and subtropical eucalypt woodlands across the Northern Territory, Queensland and New South Wales (Equation 3.5).

\section{Equation 3.5}

$\ln (A G B)=-2.0596+2.1561 \ln (D)+0.1362(\ln (H))^{2}\left(\mathrm{~kg} \mathrm{tree}^{-1}\right)$

In Equation 3.5, $D$ is the dbh at $1.3 \mathrm{~m}$ (dbh range $3-86 \mathrm{~cm}$ ) and $H$ is the tree height $(\mathrm{m})$. Williams et al. found that there was good (1:1) agreement between observed and predicted values of $A G B$ following the back-transformation of the logarithm. This implies that no correction factor needs to be applied to adjust for bias. Although the Jonson equation does not include $H$, there is good agreement between the predictions of

6 The basic density of wood is the ratio of dry mass to fresh volume. 
AGB by the Jonson and Williams equations (Figure 3.5). In Figure 3.5, there is some scatter of points around the regression line because the relationship between dbh and height is not consistent in the field data set. That is to be expected because our field data include a wide range of species and age classes and many stems have suffered damage from fire, timber cutting, wind and termites. The GWW inventory data included measurements of height and dbh, so Equation 3.5 was used to estimate $A G B$ of trees having dbh of $10 \mathrm{~cm}$ or more at our field sites.

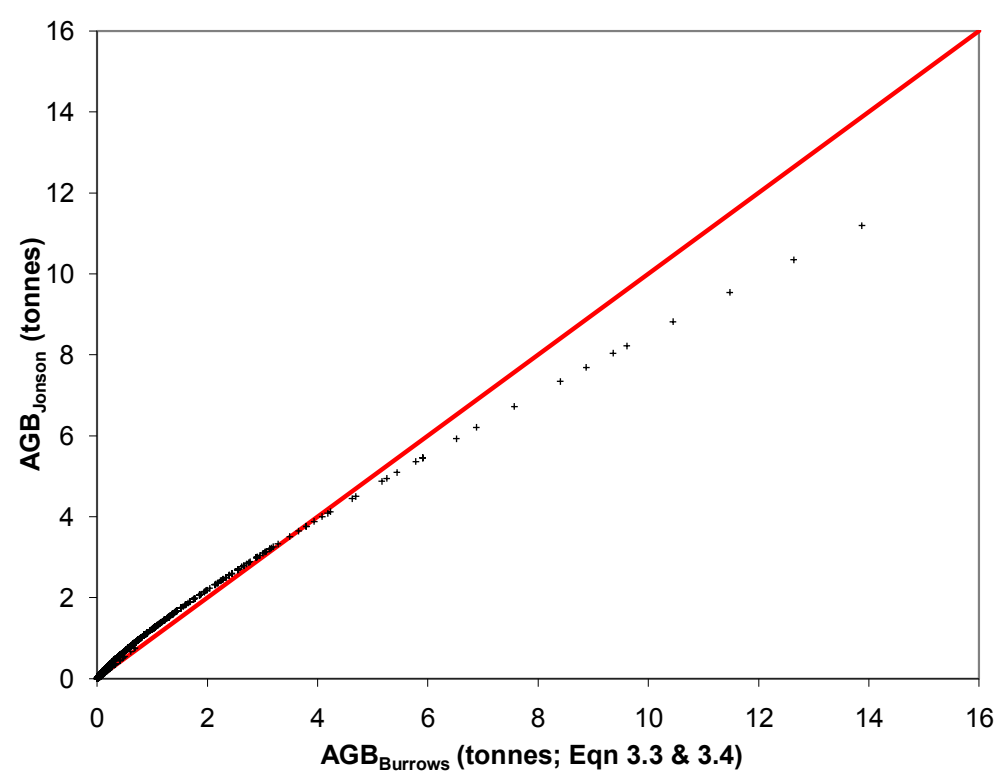

Figure 3.4 Comparison of AGB predictions from stem diameter (dbh) using the general allometric equation of Jonson and the combined equations (Equation 3.3 and 3.4) of Burrows et al. The data points are calculated AGB values (tonnes per tree) from field measurements of $\mathrm{dbh}$ of individual trees. The red line indicates a 1:1 relationship.

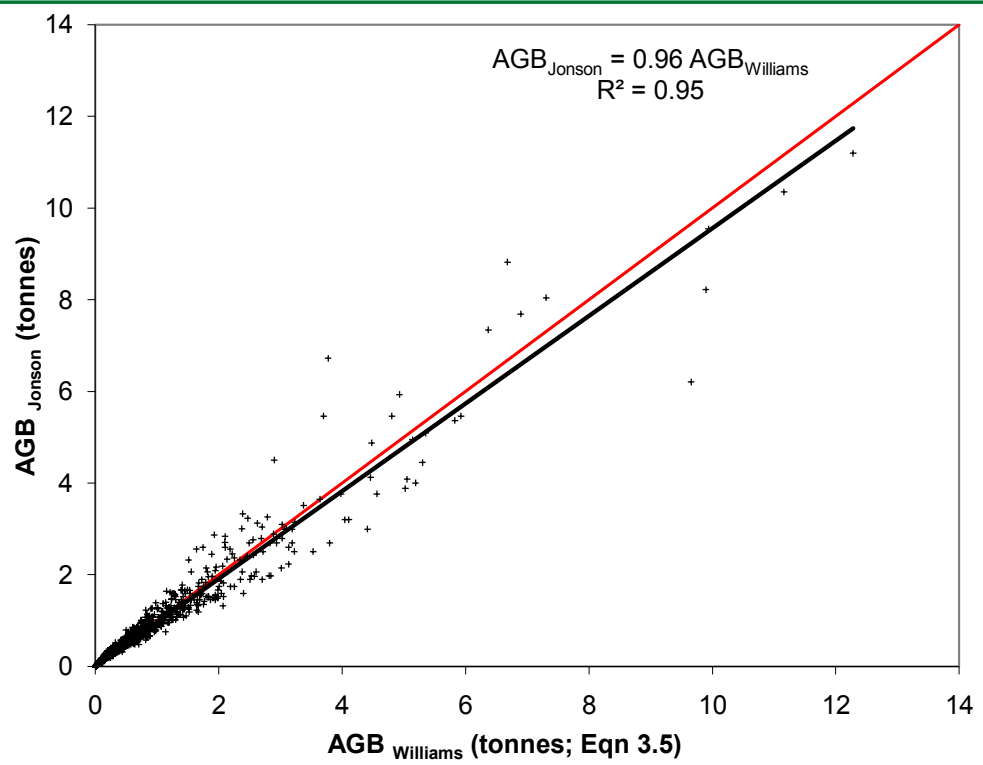

Figure 3.5 Comparison of AGB (tonnes per tree) predicted for GWW trees using Equation 3.5 (Williams et al.) and the general equation derived by Jonson. The regression line is drawn in black. The 1:1 line is drawn in red. 
Table 3.1 Estimates of above-ground biomass ( $A G B, t$ ha-1) for GWW field sites. The mixed model AGB comprises the combined estimates of tree and shrub AGB from Equations 3.5 and 3.7.

\begin{tabular}{|c|c|c|c|c|c|c|}
\hline Site no & Survey ID & $\begin{array}{c}\text { Field vegetation } \\
\text { description }\end{array}$ & $\begin{array}{c}\text { Stand (tree) } \\
\text { basal area } \\
\left(\mathrm{m}^{2} \mathrm{ha}^{-1}\right)\end{array}$ & $\begin{array}{c}\text { AGB Burrows } \\
\text { Equation } 3.1 \\
\left(\dagger \mathrm{ha}^{-1}\right)\end{array}$ & $\begin{array}{l}\text { AGB Burrows } \\
\text { Equation } 3.2 \\
\left(\dagger \mathrm{ha}^{-1}\right)\end{array}$ & $\begin{array}{c}\text { Mixed model } \\
\text { AGB } \\
\left(\dagger \mathrm{ha}^{-1}\right)\end{array}$ \\
\hline 1 & 2005_01 & Eucalypt woodland & 4.90 & 25.24 & 29.88 & 46.47 \\
\hline 2 & 2005_02 & $\begin{array}{l}\text { Open eucalypt } \\
\text { woodland }\end{array}$ & 1.48 & 2.98 & 9.02 & 6.14 \\
\hline 3 & 2005_03 & Low shrubland & no data & - & - & 0.57 \\
\hline 4 & 2005_04 & Low shrubland & no data & - & - & 2.37 \\
\hline 5 & 2005_05 & Eucalypt woodland & 8.40 & 48.02 & 51.22 & 36.11 \\
\hline 6 & 2005_06 & Eucalypt woodland & 6.04 & 32.70 & 36.87 & 47.51 \\
\hline 7 & 2005_07 & Eucalypt woodland & 8.56 & 49.10 & 52.24 & 48.75 \\
\hline 8 & 2005_08 & Tall shrubland & no data & - & - & 2.01 \\
\hline 9 & 2005_09 & Eucalypt woodland & 4.34 & 21.58 & 26.45 & 31.80 \\
\hline 10 & 2005_10 & Tall shrubland & no data & - & - & 5.00 \\
\hline 11 & 2006_01 & $\begin{array}{l}\text { Low eucalyptus } \\
\text { woodland }\end{array}$ & 1.42 & 2.60 & 8.67 & 10.95 \\
\hline 12 & 2006_02 & Eucalypt woodland & 7.59 & 42.75 & 46.29 & 57.63 \\
\hline 13 & 2006_03 & Eucalypt woodland & 11.89 & 70.78 & 72.55 & 47.28 \\
\hline 14 & 2006_04 & Eucalypt woodland & 5.74 & 30.71 & 35.01 & 49.10 \\
\hline 15 & 2006_05 & Eucalypt woodland & 5.40 & 28.50 & 32.94 & 38.33 \\
\hline 16 & 2006_06 & Tall acacia shrubland & 0.07 & -6.18 & 0.44 & 4.35 \\
\hline 17 & 2006_07 & Tall acacia shrubland & 0.33 & -4.49 & 2.02 & 6.05 \\
\hline 18 & 2007_01 & Mallee shrubland & 3.22 & 14.28 & 19.61 & 22.86 \\
\hline 19 & 2007_02 & Eucalypt woodland & 5.30 & 27.83 & 32.30 & 38.19 \\
\hline 20 & 2007_03 & Eucalypt woodland & 10.36 & 60.82 & 63.22 & 89.96 \\
\hline 21 & 2007_04 & $\begin{array}{l}\text { Heath/mallee } \\
\text { shrubland }\end{array}$ & no data & - & - & 2.12 \\
\hline
\end{tabular}


Bejan et al. (2008) have proposed that tree stems and branches have a near-conical shape, related to the mechanics of structural support and water flow through the stem and branches. In that case, there could be a simple relationship between AGB and the volume of a cone or cylinder (the volume of a cone is equal to one-third of the volume of a cylinder). For our field data set of eucalypt trees, AGB predicted by Equation 3.5 is approximately equivalent to Equation 3.6.

Equation 3.6

$A G B_{c y l}=\pi r^{2} h 0.56\left(\mathrm{~kg} \mathrm{tree}^{-1}\right)$

In Equation 3.6, $r$ is the stem radius at $1.3 \mathrm{~m}, h$ is the height to the top of the canopy and the units are metres. The comparison between $A G B_{c y l}$ and $A G B$ predicted from Equation 3.5 is shown in Figure 3.6. We use this simple relationship to estimate the $A G B$ of the shrub layer.

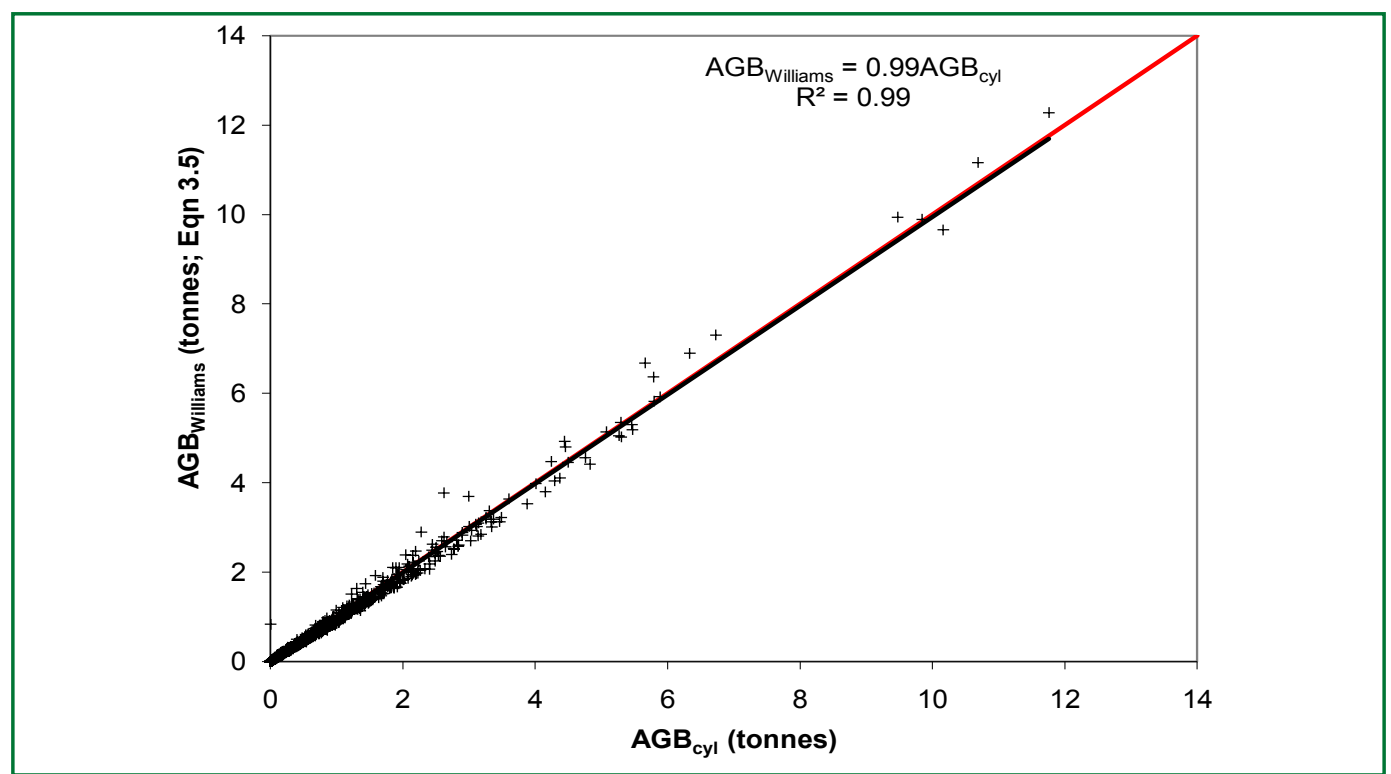

Figure 3.6 AGB (tonnes per tree) estimated from eucalypt tree and mallee measurements from our site data. The allometric equation of Williams developed for northern Australian eucalypts yields very similar estimates to those derived from the formula for a truncated cone $\left(0.56 w \mathrm{r}^{2} \mathrm{~h}\right.$, in which the constant was derived from calibration with Equation 3.5$)$.

Estimates of forest biomass commonly ignore the contribution of the shrub layer; however, about 6 million ha of the GWW has an upper canopy layer of low trees or shrubs (canopy height classes $L, S$ and $Z$ in Table 2.1). We measured canopy dimensions and height but not dbh for many trees with $\mathrm{dbh}<10 \mathrm{~cm}$ and for almost all of the shrubs recorded in our field data. Consequently, none of the allometric equations requiring a stem diameter measurement was useful for estimating shrub biomass. Allometric equations, which utilise canopy dimensions to predict arid and semi-arid shrub biomass, are considered inadequate for sites distant from the locations from which the equations were derived (Dean and Eldridge 2008). (The equations in that study yielded biomass estimates that differed by 85 per cent.) An equation that estimates AGB from height at the top of the canopy was required. We could find no suitable published equations (the equations of Harrington 1979 relate biomass to height but the species and form of the shrubs are different to those at the GWW). Instead, we derived an equation relating AGB to height for 114 plants (mostly eucalypts) that have $\mathrm{dbh}<10 \mathrm{~cm}$ for which we recorded a dbh measurement. First, we calculated AGB using: 1) the general allometric equation of Jonson; 2) Equation 3.4; 3) Equation 3.5; and 4) Equation 3.6. Of these equations, the best predictor of AGB from height ( $\mathrm{m}$ ) was Equation 3.6 (see Figure 3.7 and Equation 3.7). 


\section{Equation 3.7}

$A G B=0.0002 \mathrm{~h}^{2.4071}\left(\mathrm{~kg} \mathrm{plant}^{-1}\right)$

This equation was subsequently used to estimate the AGB of shrubs at each field site. The summed AGB for all canopy layers is presented in Table 3.1.

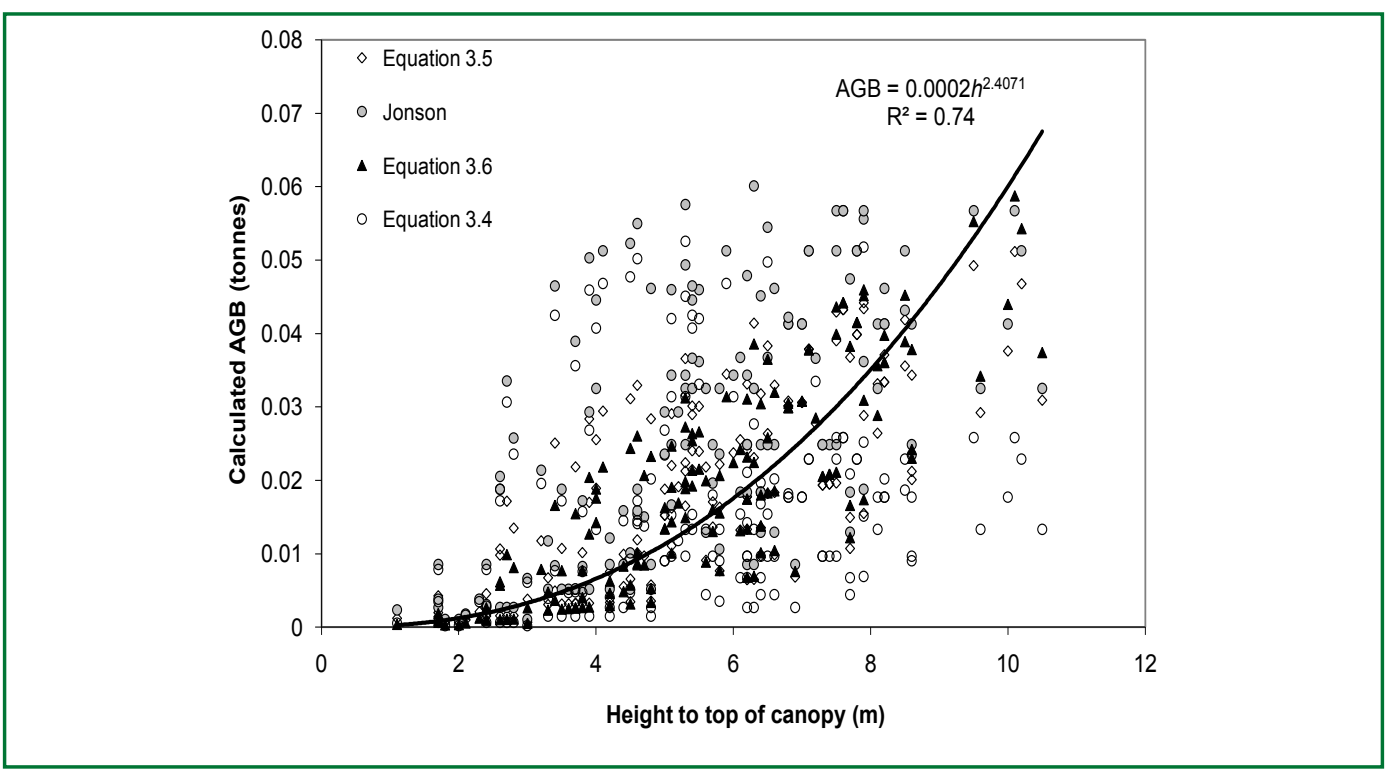

Figure 3.7 Relationship between measured canopy height and calculated AGB (tonnes per plant) for 114 small trees or shrubs having $\mathrm{dbh}<10 \mathrm{~cm}$. The equation displayed on the graph (Equation 3.7) yields the best prediction of AGB (based on Equation 3.6) from height for these small trees and shrubs.

Below-ground biomass (BGB) or root biomass is usually estimated as a ratio of aboveground biomass. The most appropriate ratios to use for the GWW are based on site data for similar species and environmental conditions; estimates obtained for a range of Australian woodlands are summarised in Table 3.2. The value obtained from the generic equations of Jonson (n.d.) was in close agreement with the values given in Table 3.2 for Oakvale and Howard Springs. Therefore, we used the ratio of BGB:AGB obtained from the analysis of Jonson to estimate BGB at our field survey sites.

Table 3.2 Summary of estimated ratio of below-ground biomass to above-ground biomass for a range of Australian woodlands.

\begin{tabular}{|c|c|c|c|c|}
\hline Species & Location & $\begin{array}{l}\text { Rainfall } \\
\left(\mathrm{mm} \mathrm{yr}^{-1}\right)\end{array}$ & BGB:AGB & Source \\
\hline E. populnea & Oakvale, NSW & 367 & 0.58 & $\begin{array}{l}\text { Zerihun et al. } \\
\qquad(2006)\end{array}$ \\
\hline E. populnea & Roma, Qld & 602 & 0.42 & $\begin{array}{l}\text { Zerihun et al. } \\
\qquad(2006)\end{array}$ \\
\hline $\begin{array}{l}\text { E. miniata, } E \text {. } \\
\text { tetradonta }\end{array}$ & $\begin{array}{l}\text { Howard Springs, } \\
\text { Humpty Doo, } \\
\text { Wildlife Park, NT }\end{array}$ & $1200->1400$ & 0.64 & $\begin{array}{l}\text { Chen et al. } \\
\text { (2003) }\end{array}$ \\
\hline $\begin{array}{c}\text { Several eucalypts, } \\
\text { see Table A3 }\end{array}$ & Wheatbelt, WA & 300-500 & 0.60 & Jonson \\
\hline
\end{tabular}


We had no field measurements of the three components of dead above-ground biomass $\left(A G B_{\text {dead }}\right)$ for the GWW: standing deadwood (SDW), coarse woody debris (CWD) on the ground and litter (Lit). In a review of $A G B_{\text {dead }}$ in Australian forests (Woldendorp and Keenan 2005), data from two woodland studies gave $A G B_{\text {dead }}$ equivalent to 26 per cent of the total $A G B_{\text {total }}\left(A G B_{\text {living }}+A G B_{\text {dead }}\right)$. For open forests, the percentage of $A G B_{\text {dead }}: A G B_{\text {total }}$ (five studies) was 25 per cent. SDW was $\sim 7$ per cent of $A G B_{\text {total }}$ in the TRAPS study in Queensland woodlands (Burrows et al. 2002). In contrast, the mean percentage of SDW:AGB ${ }_{\text {total }}$ reported by Woldendorp and Keenan (2005) was 15.6 per cent for the two woodland studies and 1.9 per cent for the five open-forest studies. Based on these studies, we assume that $A G B_{\text {dead }}: A G B_{\text {total }}$ for woodlands within the GWW is 26 per cent.

Total biomass was calculated as the sum of $A G B_{\text {living }} B G B$ and $A G B_{\text {dead }}$. The site-based estimates of total biomass are given in Table 3.3. The sites having the greatest total biomass (79-198 $\left.\mathrm{tha}^{-1}\right)$ are eucalypt woodlands. In contrast, the total biomass of the mallee, heath and other shrubland sites ranges from 2 to $50 \mathrm{tha}^{-1}$.

\subsection{DATA LAYERS FOR SPATIAL EXTRAPOLATION}

In this section, we investigate how a range of factors - for which we have spatial datacould influence biomass. Those factors that are shown to be important are consequently taken into account in the spatial modelling process by which we extrapolate from the 21 field sites to estimate the total biomass and carbon stock of the $~ 16$ million ha of the GWW.

\subsubsection{Vegetation mapping}

The NVIS MVG classes (DEWHA 2005) compare reasonably well with our observations at our field sites (Table 3.4). In some cases, however (specifically sites 3, 4, 10, 11 and 21), we did not observe the upper tree or shrub layer, and in some cases (sites 1, 2 and 9) we observed a tree layer at sites classified by NVIS as mallee woodland and shrubland. One possible explanation for these disparities is that the vegetation has changed in the period since the NVIS mapping data were collected (which was at variable times before 2005 in different regions of Australia). As noted, the GWW vegetation has been subjected to several types of disturbance during the past century, including fire, timber cutting, mining and mineral exploration. The areas known to be affected by these disturbances are shown in Figure 2.14. Some parts of the GWW have also been impacted on by pastoralism. 
Table 3.3 Estimated above-ground biomass, total biomass and corresponding aerial photographs of the 21 ANU field survey sites.
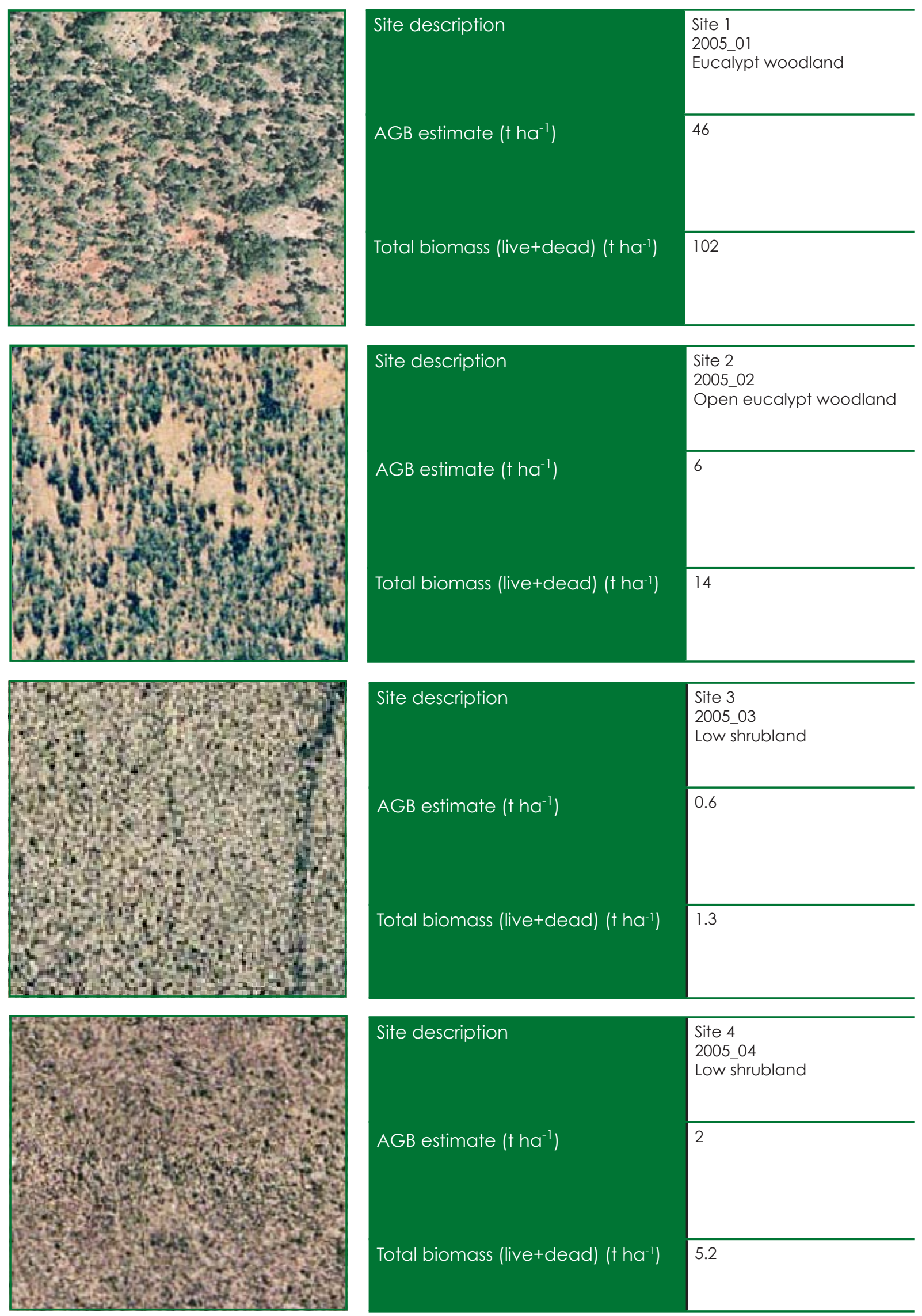
Table 3.3 Continued
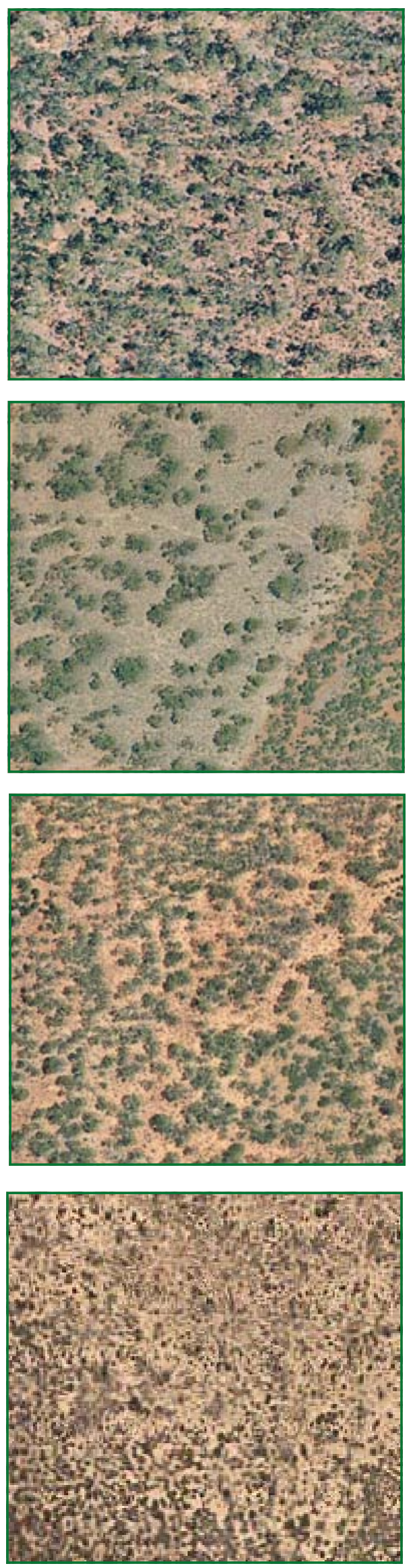
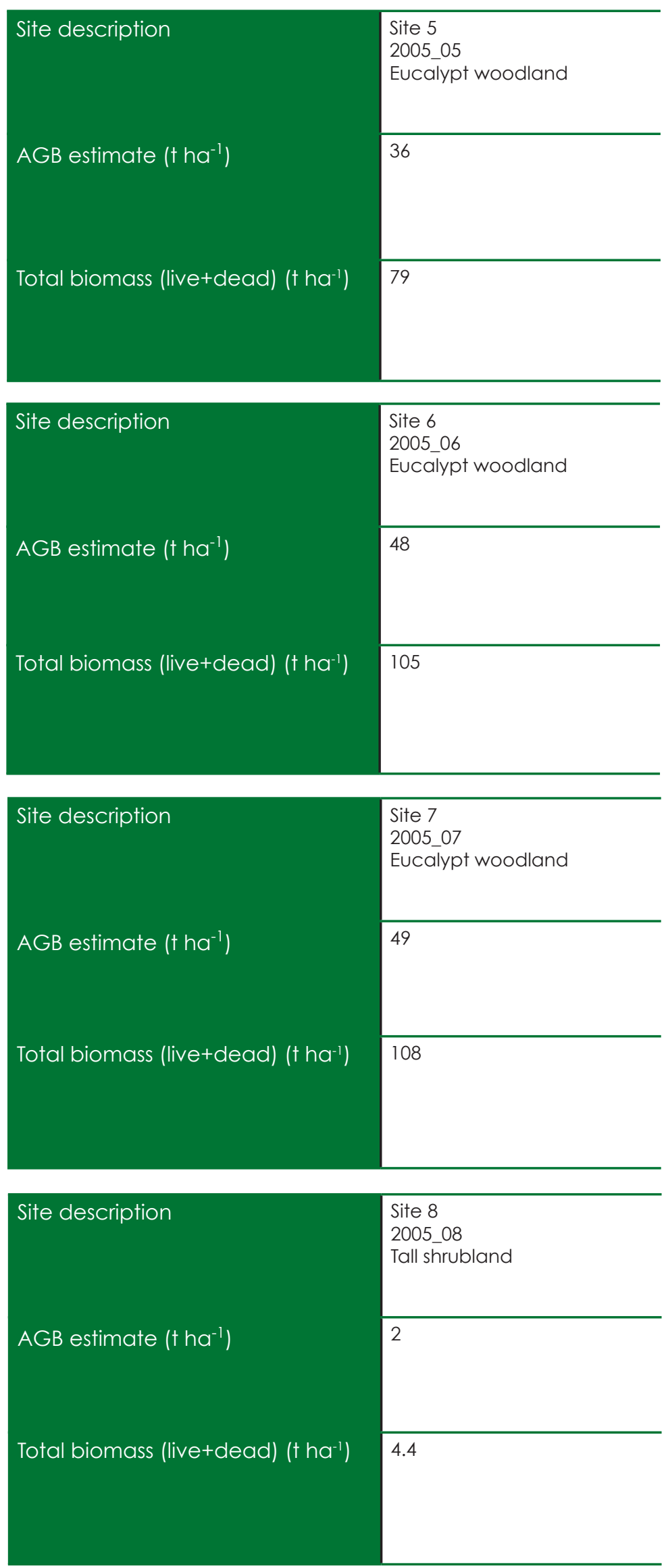
Table 3.3 Continued
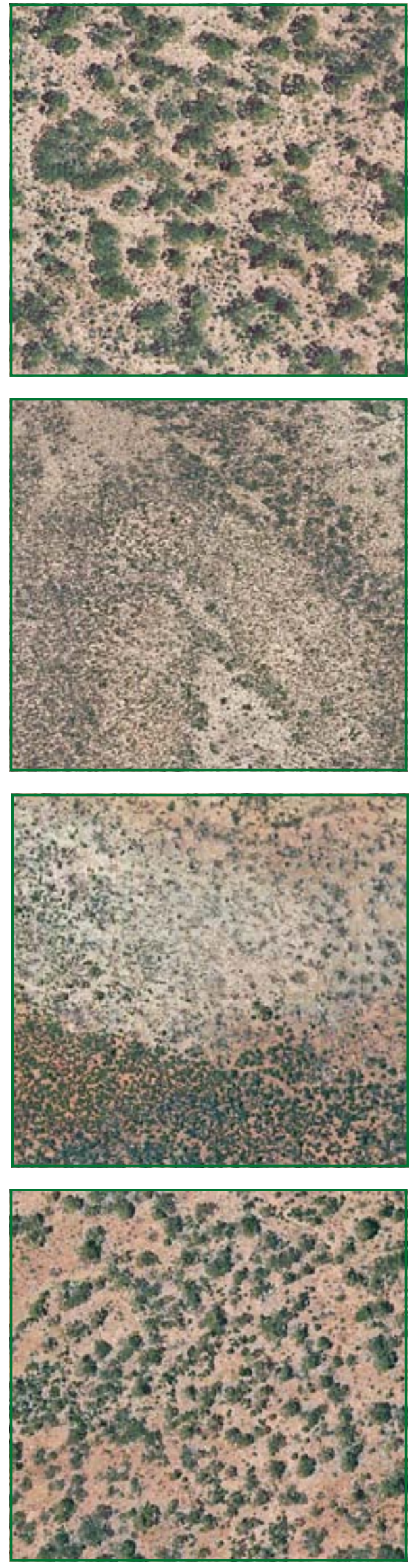
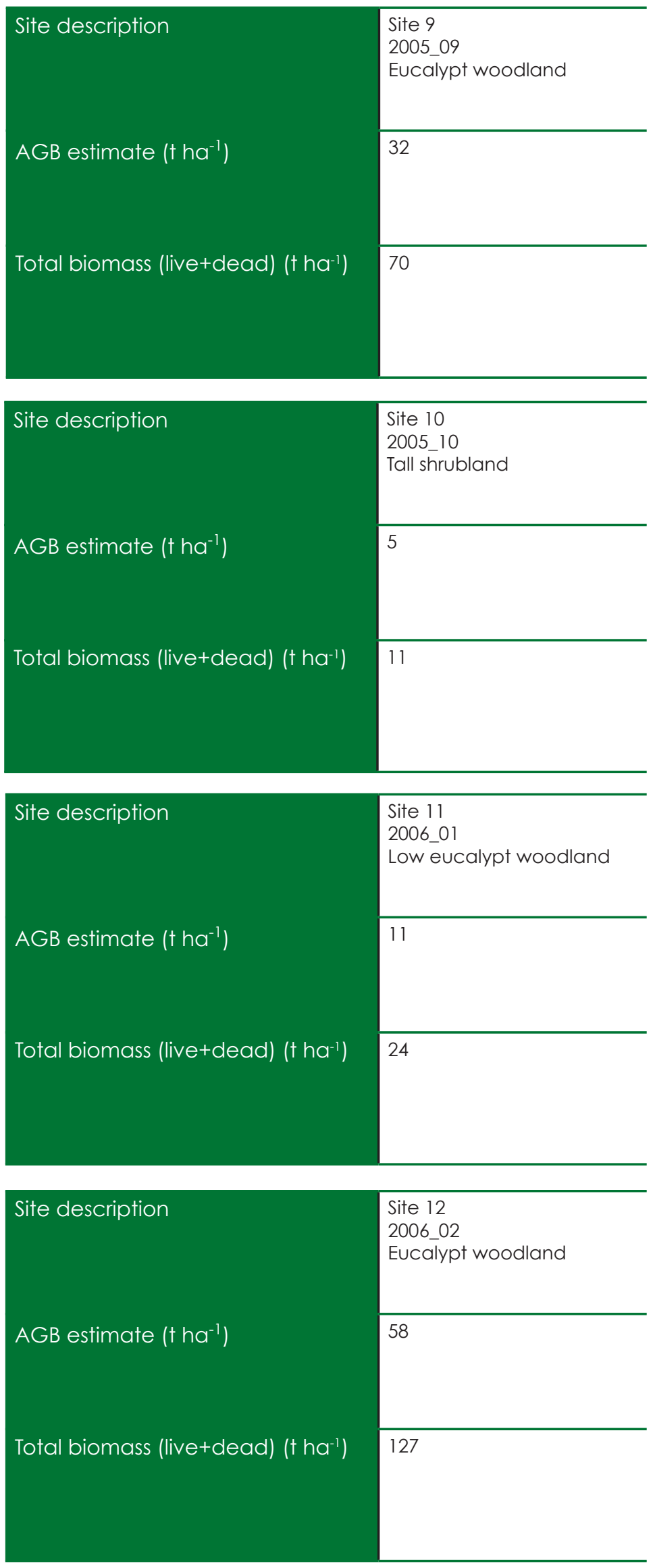
Table 3.3 Continued
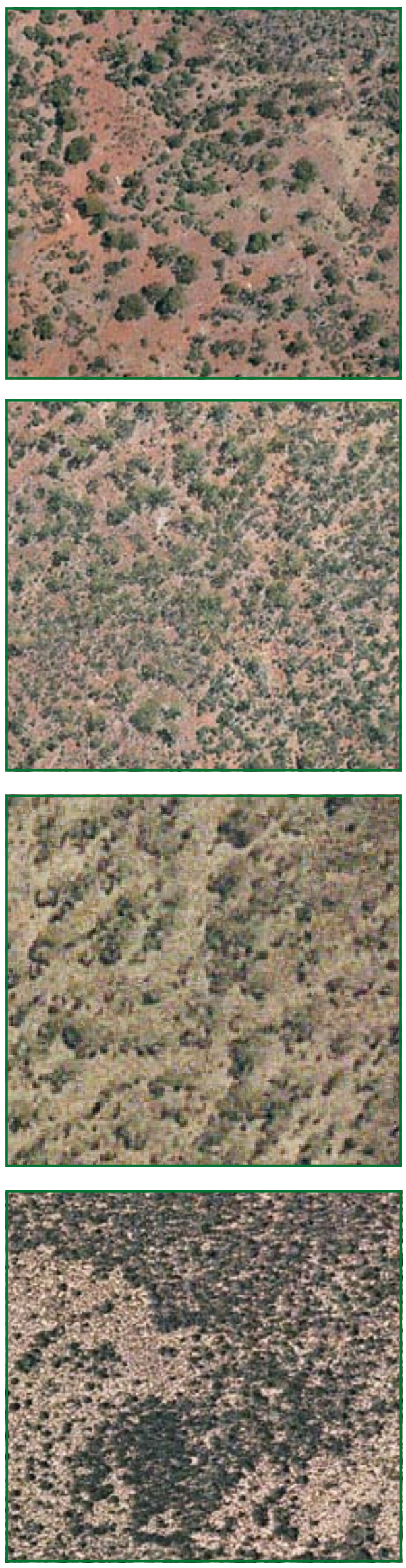
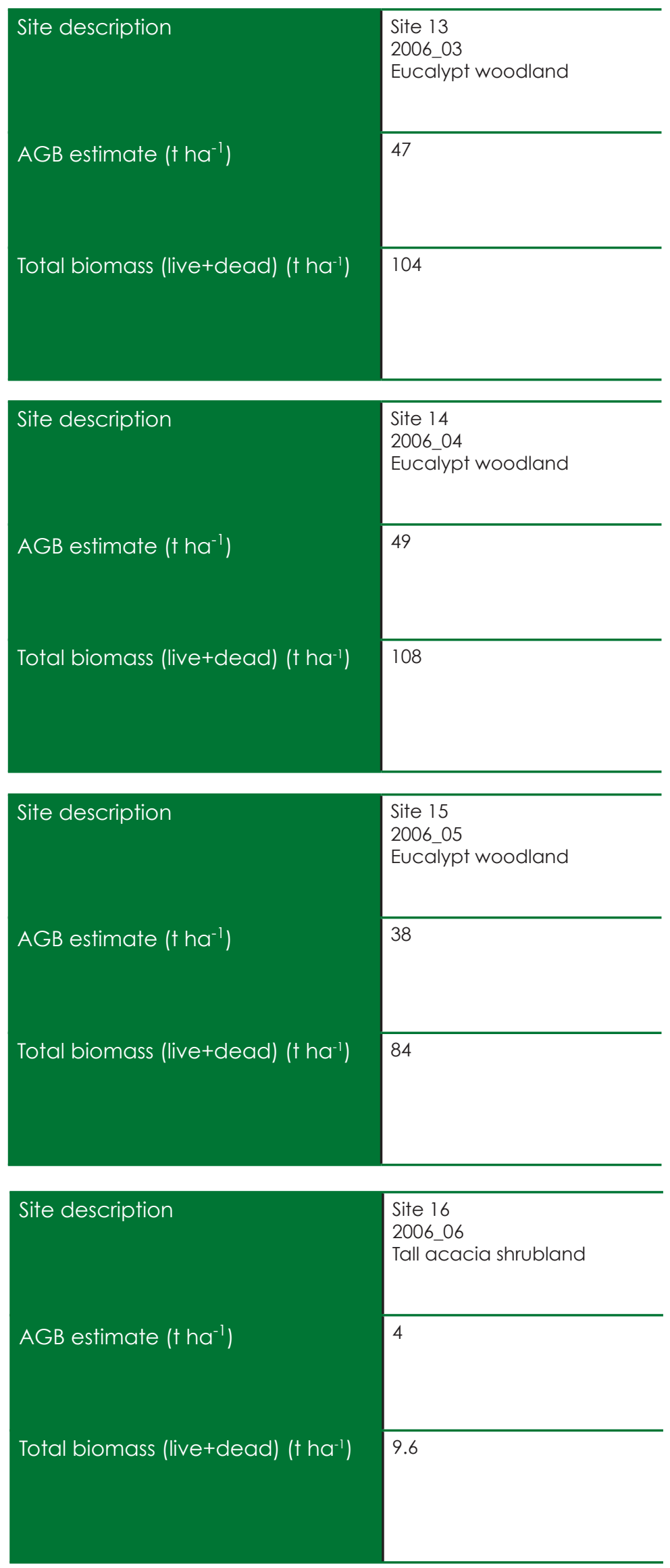
Table 3.3 Continued
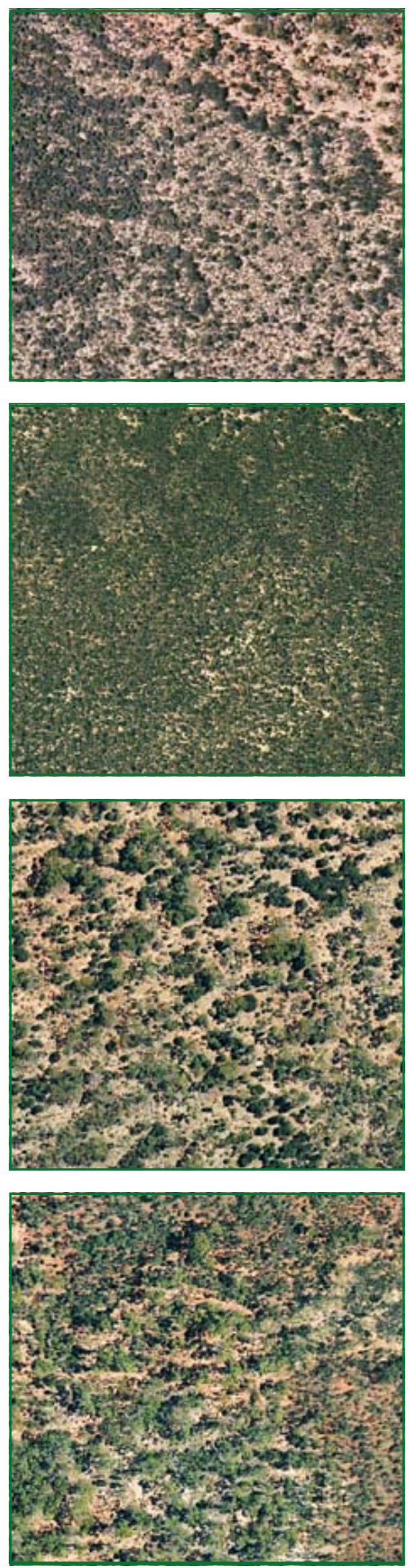
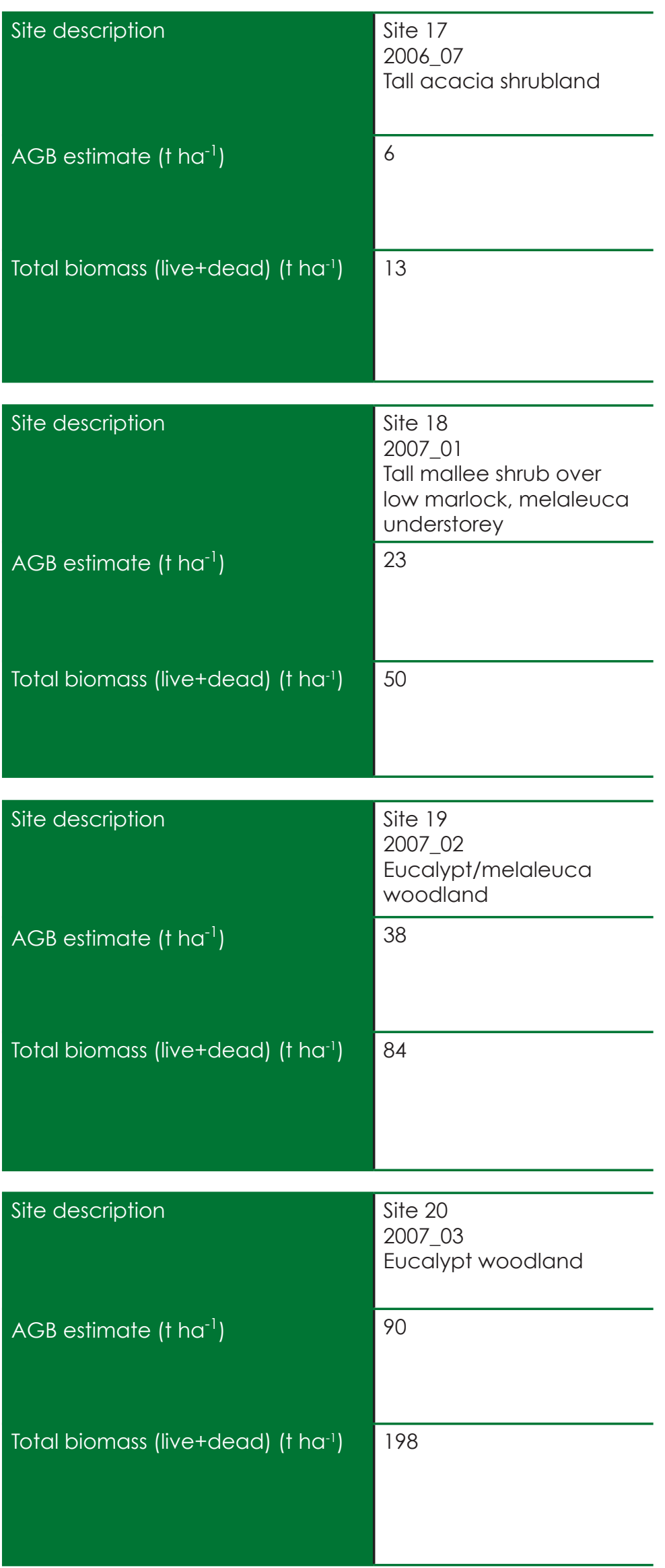
Table 3.3 Continued
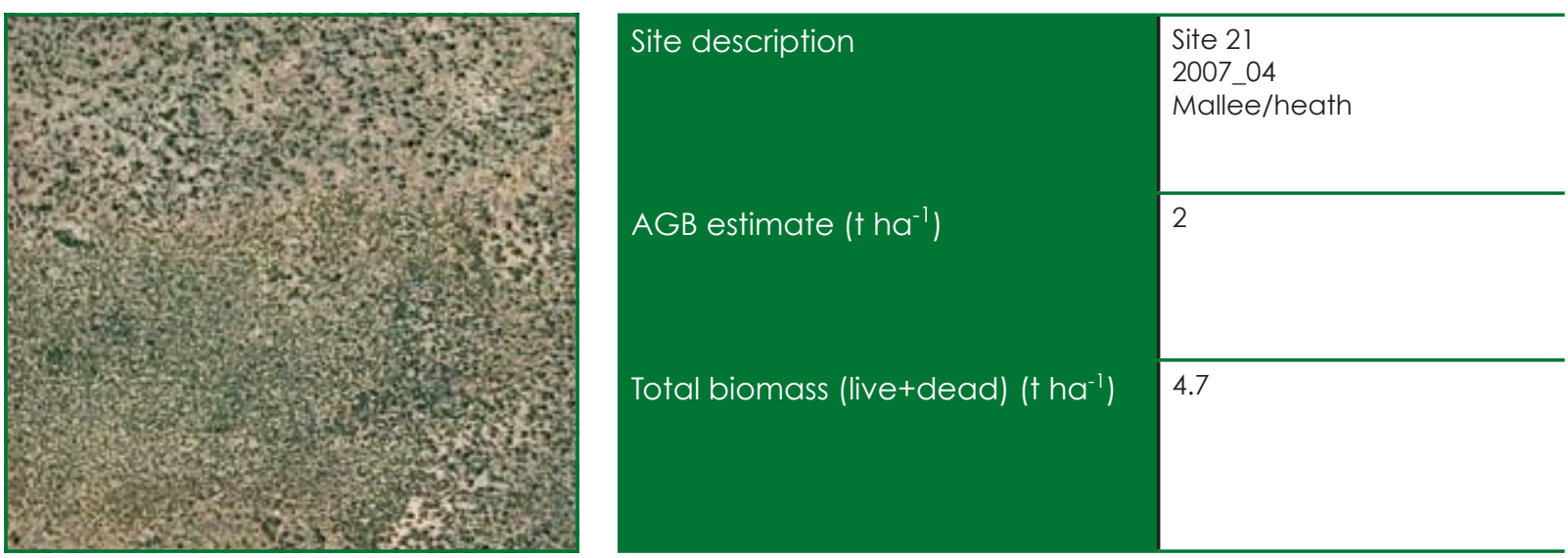

The aerial photographs are reproduced by permission of WA Land Information Authority, CL34/2010 (<www.landgate.wa.gov.au>).

Table 3.4 Comparison of vegetation description based on field observation and NVIS Major Vegetation Group (MVG) class.

\begin{tabular}{|c|c|c|c|c|}
\hline Site no. & Survey ID & $\begin{array}{l}\text { Field vegetation } \\
\text { description }\end{array}$ & $\begin{array}{l}\text { NVIS-MVG extant } \\
\text { classification code }\end{array}$ & $\begin{array}{c}\text { NVIS-MVG extant vegetation } \\
\text { description }\end{array}$ \\
\hline 1 & 2005_01 & Eucalypt woodland & 14 & Mallee woodlands and shrublands \\
\hline 2 & 2005_02 & $\begin{array}{l}\text { Open eucalypt } \\
\text { woodland }\end{array}$ & 14 & Mallee woodlands and shrublands \\
\hline 3 & 2005_03 & Low shrubland & 14 & Mallee woodlands and shrublands \\
\hline 4 & 2005_04 & Low shrubland & 14 & Mallee woodlands and shrublands \\
\hline 5 & 2005_05 & Eucalypt woodland & 5 & Eucalypt woodland \\
\hline 6 & 2005_06 & Eucalypt woodland & 5 & Eucalypt woodland \\
\hline 7 & 2005_07 & Eucalypt woodland & 5 & Eucalypt woodland \\
\hline 8 & 2005_08 & Tall shrubland & 17 & Other shrubland \\
\hline 9 & 2005_09 & Eucalypt woodland & 14 & Mallee woodlands and shrublands \\
\hline 10 & 2005_10 & Tall shrubland & 14 & Mallee woodlands and shrublands \\
\hline 11 & 2006_01 & $\begin{array}{l}\text { Low eucalypt } \\
\text { woodland }\end{array}$ & 5 & Eucalypt woodland \\
\hline 12 & 2006_02 & Eucalypt woodland & 5 & Eucalypt woodland \\
\hline 13 & 2006_03 & Eucalypt woodland & 5 & Eucalypt woodland \\
\hline 14 & 2006_04 & Eucalypt woodland & 5 & Eucalypt woodland \\
\hline 15 & 2006_05 & Eucalypt woodland & 5 & Eucalypt woodland \\
\hline 16 & 2006_06 & Tall acacia shrubland & 15 & $\begin{array}{l}\text { Low closed forest and tall } \\
\text { shrubland }\end{array}$ \\
\hline 17 & 2006_07 & Tall acacia shrubland & 15 & $\begin{array}{l}\text { Low closed forest and tall } \\
\text { shrubland }\end{array}$ \\
\hline 18 & 2007_01 & Mallee shrubland & 14 & Mallee woodlands and shrublands \\
\hline 19 & 2007_02 & Eucalypt woodland & 5 & Eucalypt woodland \\
\hline 20 & 2007_03 & Eucalypt woodland & 5 & Eucalypt woodland \\
\hline 21 & 2007_04 & $\begin{array}{l}\text { Heath/mallee } \\
\text { shrubland }\end{array}$ & 5 & Eucalypt woodland \\
\hline
\end{tabular}

Source: NVIS MVG DEWHA (2005). 


\subsubsection{Recent fire history}

The occurrence of wildfire can be detected through the analysis of time-series of satellite imagery. We used remotely sensed data from two satellite-based sourcesnamely: Landsat images ${ }^{7}$ at 30 m pixel resolution (1972, 1977, 1980, 1985, 1988, 1989, 1991, 1992, 1995, 1998, 2000 and 2002) and MODIS (or Moderate Resolution Imaging Spectroradiometer) images at $250 \mathrm{~m}$ pixel resolution beginning in 2000 (see Section 3.2.7 for details). While having a coarser pixel resolution, the MODIS data were processed to produce an essentially cloud-free time-series on a one-month time step (see Berry et al. 2007). Using these data, fire footprints over intensely burnt areas were highlighted through 'difference images', which show changes that have occurred between subsequent images. We used this analytical approach to map areas that were severely burnt by large landscape fires beginning circa 1972. The extent and frequency of these fires are shown in Figure 3.8.

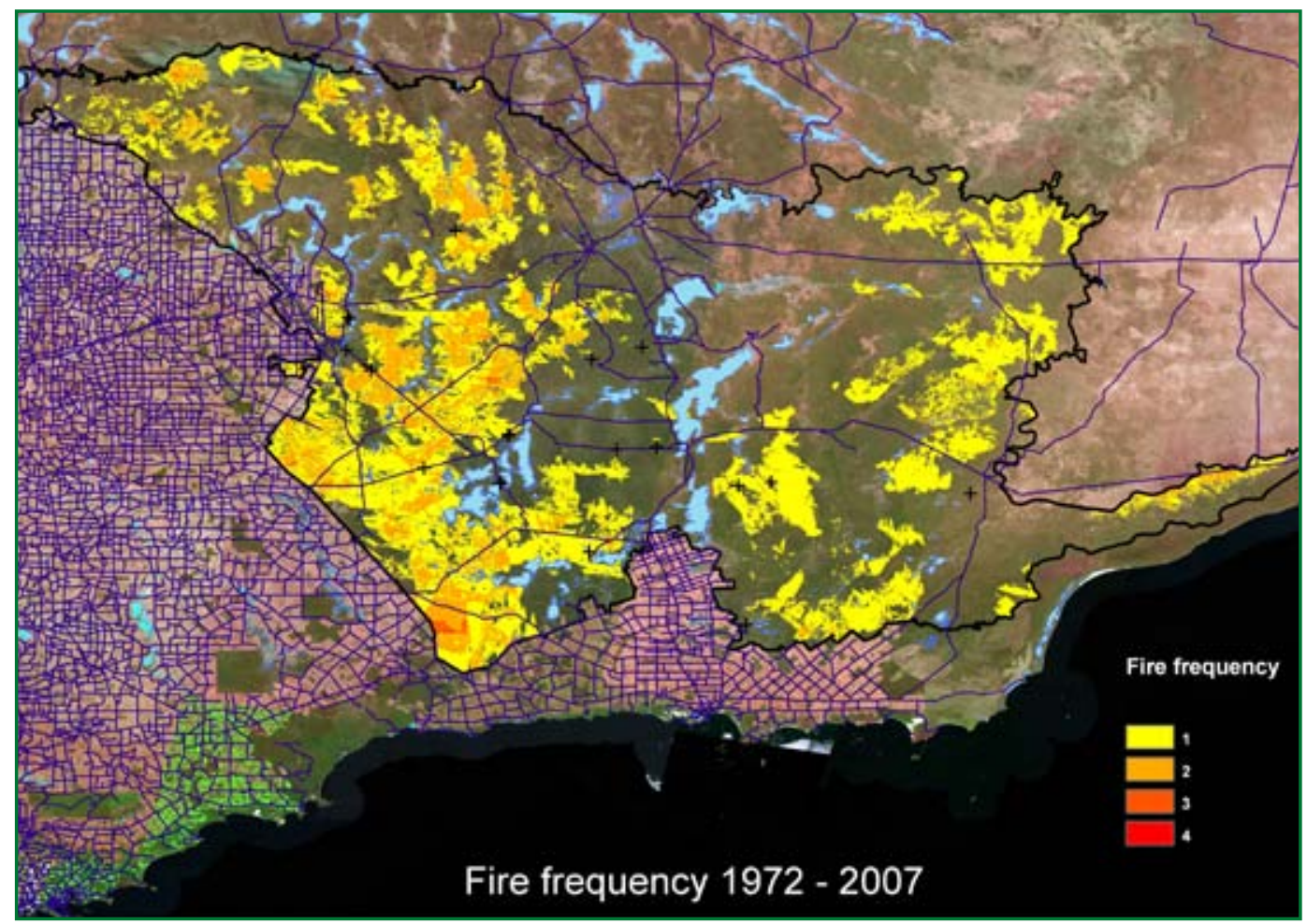

Figure 3.8 Area identified as being burnt by intense wildfires between 1972 and 2007. The base map is the Landsat 2005 layer. The fire frequency indicates the number of times an area within the GWW has been burnt by intense fires over the period. The base map is visible in areas within the GWW having a fire frequency of zero between 1972 and 2007 . Fire frequencies are not shown for areas outside the GWW boundary. The salt lakes are coloured blue. Major roads are shown in blue and + signs indicate the location of ANU field survey sites.

Spatial data sources: see Table Al-Fire mapping, MODIS, WA Landcover, Roads. This figure incorporates Landsat 2005 data and road location data that are Copyright State of Western Australia 2007, and Landsat Continental Mosaic (AGO) data that are Copyright Commonwealth of Australia 2010.

We found that all five sites for which our vegetation structure observations differed from the NVIS MVG mapping were burnt since 1972, and mostly since 1990. This suggests that either: 1) at some time after the vegetation survey for mapping, fire has altered the vegetation structure; or 2) the vegetation map used to inform NVIS depicted the climax

$7 \quad$ See Table $\mathrm{A} 1$ for details. 
vegetation instead of an intermediate successional state. Vegetation structure could change if fire caused the death of above-ground plant tissues so that subsequent regeneration is from below-ground tissues (lignotubers or roots) or from seed. The relative abundance of species can change due to differing rates of regeneration. If the fire return interval is too short then it is possible that lignotuber resources will be depleted and no re-sprouting will occur. Also, there will be insufficient time for production and accumulation of seed. This could lead to local loss of species and possibly a change in the species composition of the dominant canopy layer (for example, a eucalyptdominated canopy could be replaced with an acacia-dominated canopy). Hopkins and Robinson (1981), in their study of the effects of a single fire in the GWW, concluded that the mallee-heath vegetation was a pyric disclimax vegetation following a fire in eucalypt woodland. Beard (1968:251), in his report on mapping of vegetation of the Lake Johnston and Boorabbin areas within the GWW, noted that the eucalypt trees that dominate sclerophyll woodland are killed by fires and regenerate from seed. Beard also states that ' $[\mathrm{m}$ ] allee is subject to frequent fires which destroy the top growth, regeneration taking place from coppice. It is not clear to what extent the mallee habit is genetically controlled or due to fire.' Beard notes that 'very many' mallee species can be found in the form of moderately sized or small trees. In his description of the 'scrub heath' vegetation formation, Beard (1968:249) observed that this vegetation is 'burnt so frequently that a mature structure has little chance to develop'. The observations of Hopkins and Robinson, and Beard, suggest that fire has played a pivotal role in modifying the vegetation structure in the GWW. Observations during field surveys between 2005 and 2007 by ANU researchers support those of Hopkins and Robinson (1981) and Beard (1968) (Figures 3.9 and 3.10).

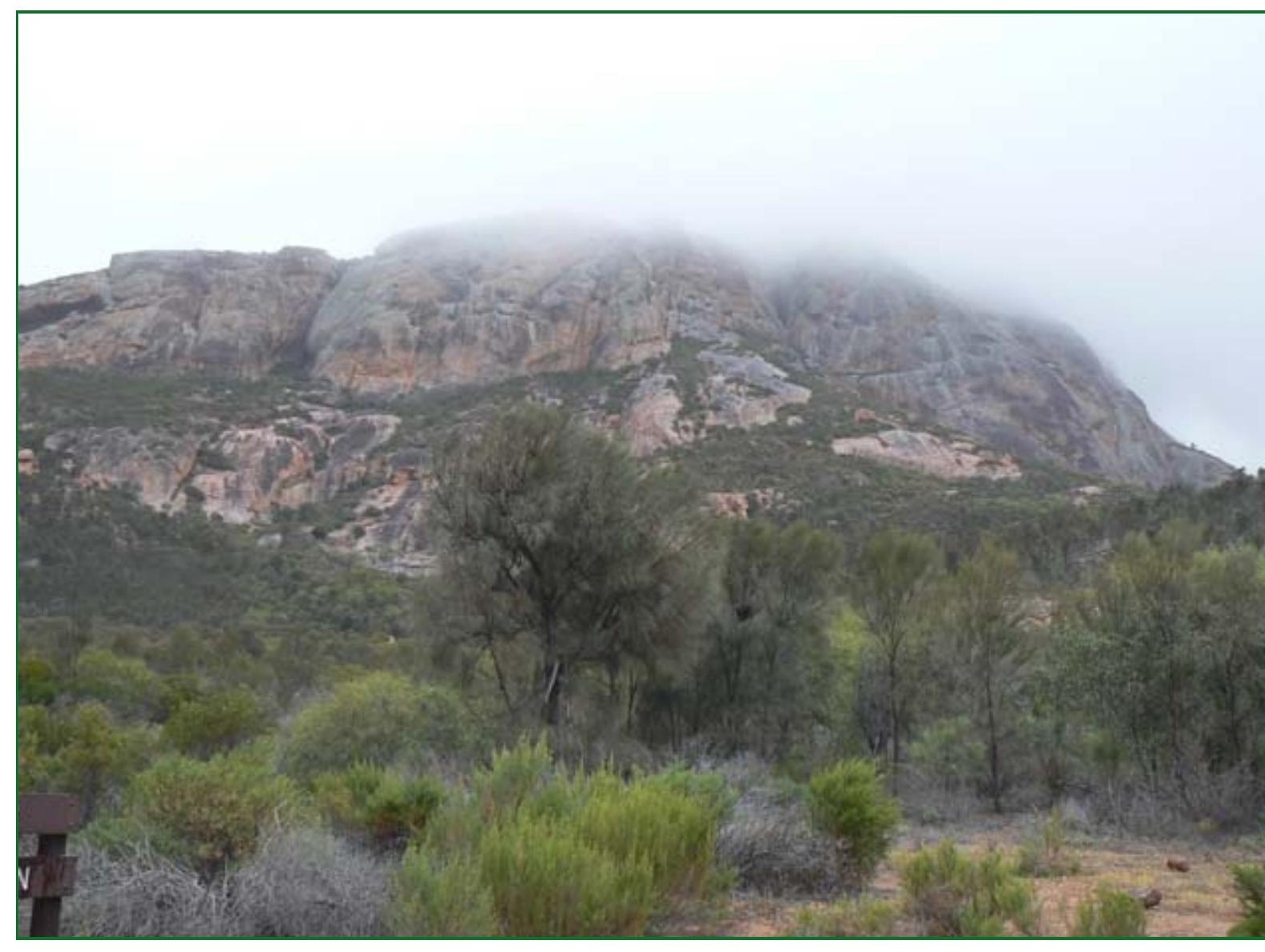



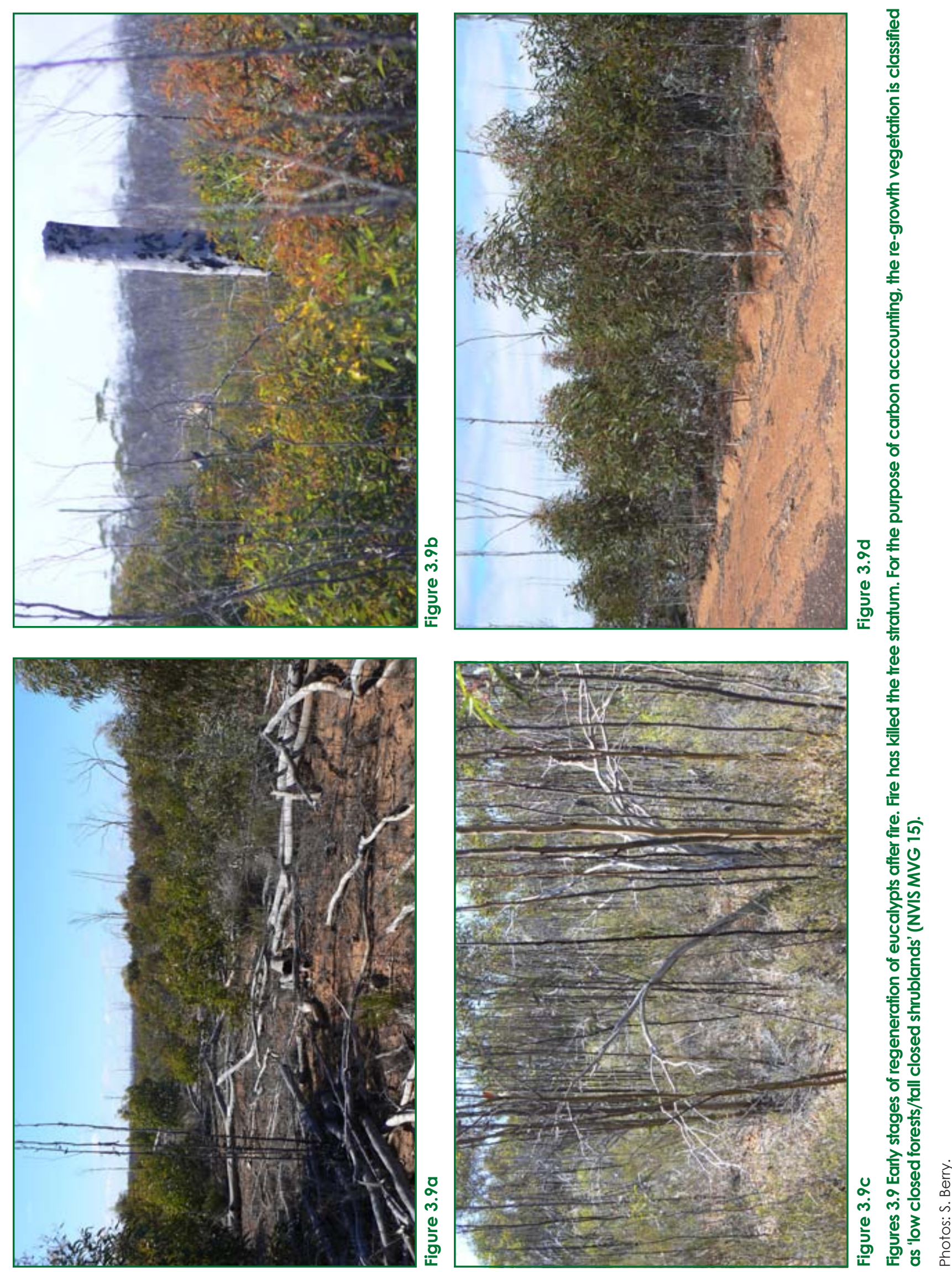


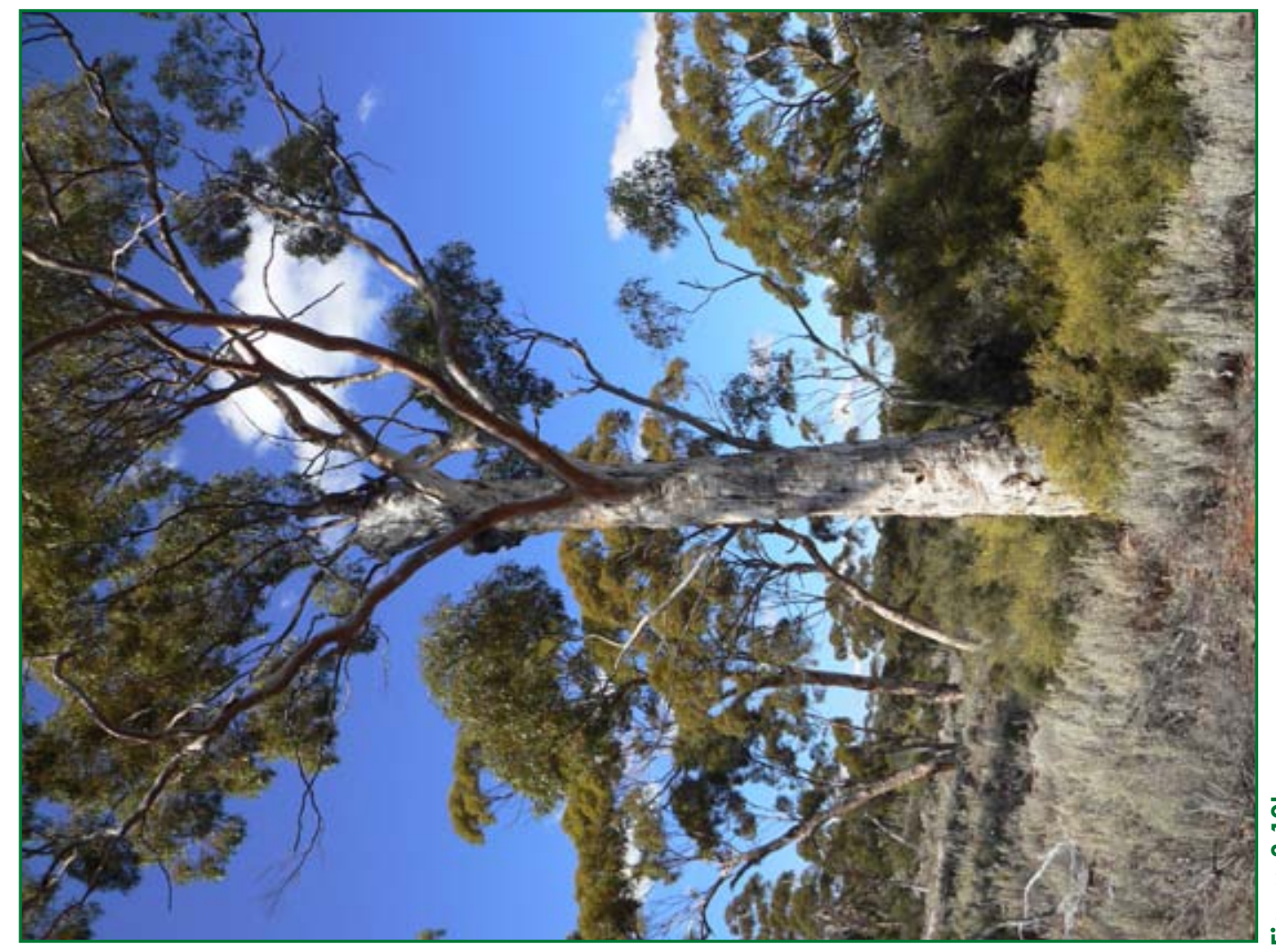

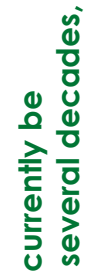

음 훈

3 잉

额

了 $\mathrm{x} .5$

is

일 울

之势

뜬

닝ㅇ

일

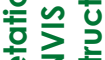

可的

흫

응 0 흥

ले

0 d

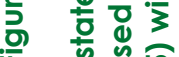

흔은

흥 호

운

范之

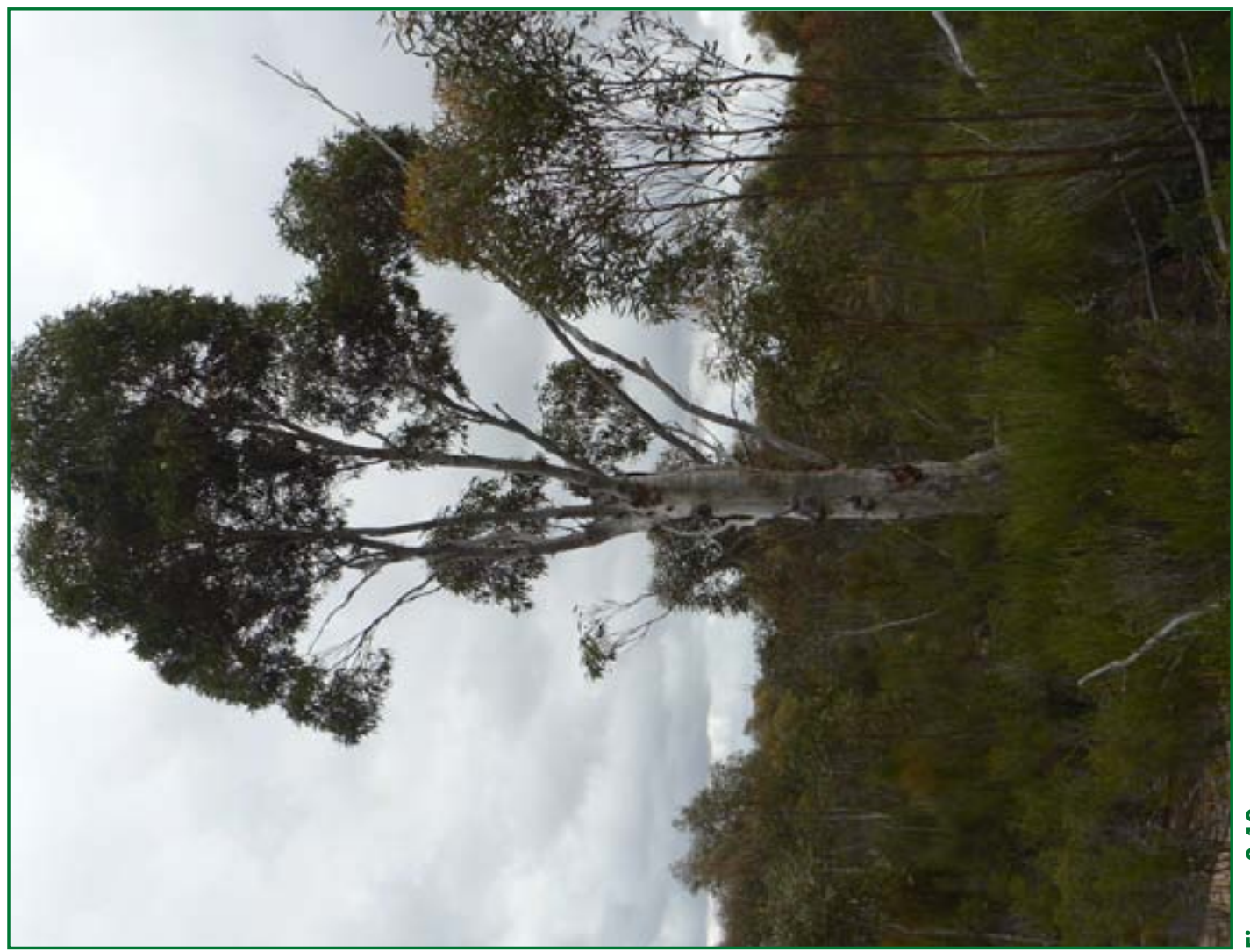

인융주

d

은은 흥

凹U유

으으 츨

的

象 응

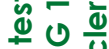

ठ초

\&

등

으으응

을

ํㅡㅇ

융 드

잏

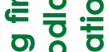

원

$>38$

记

흘할

응응

$\therefore$ 응

m m

凹 ळ

은 은흔 음 
If the vegetation structure mapping in the GWW includes pyric successional vegetation (such as that shown in Figure 3.9), we would expect congruence between boundaries of vegetation mapping units and fire footprints in addition to congruence between the vegetation and surficial geology boundaries ${ }^{8}$. We present evidence for congruence between fire footprints and vegetation boundaries in Figures 3.11 and 3.12. The mapped (MVG 5) eucalypt woodland boundaries border many footprints of fires in the period 1972-90 (Figure 3.1 1 a). Post-1990 fire footprints occur over large areas that are mapped as eucalypt woodland (Figure $3.11 \mathrm{~b}$ ), as would be expected if the vegetation map layer was derived from pre-1990 information. The presence of fire footprints over vegetation mapped as woodland (Figure 3.1 1b), along with our field observations (Figures 3.9 and 3.10), demonstrates that the eucalypt woodland has been extensively burned in the past two decades. This can be contrasted with the observation of Beard (1968:232) that woodlands, when he observed them, burned to only a minor extent.

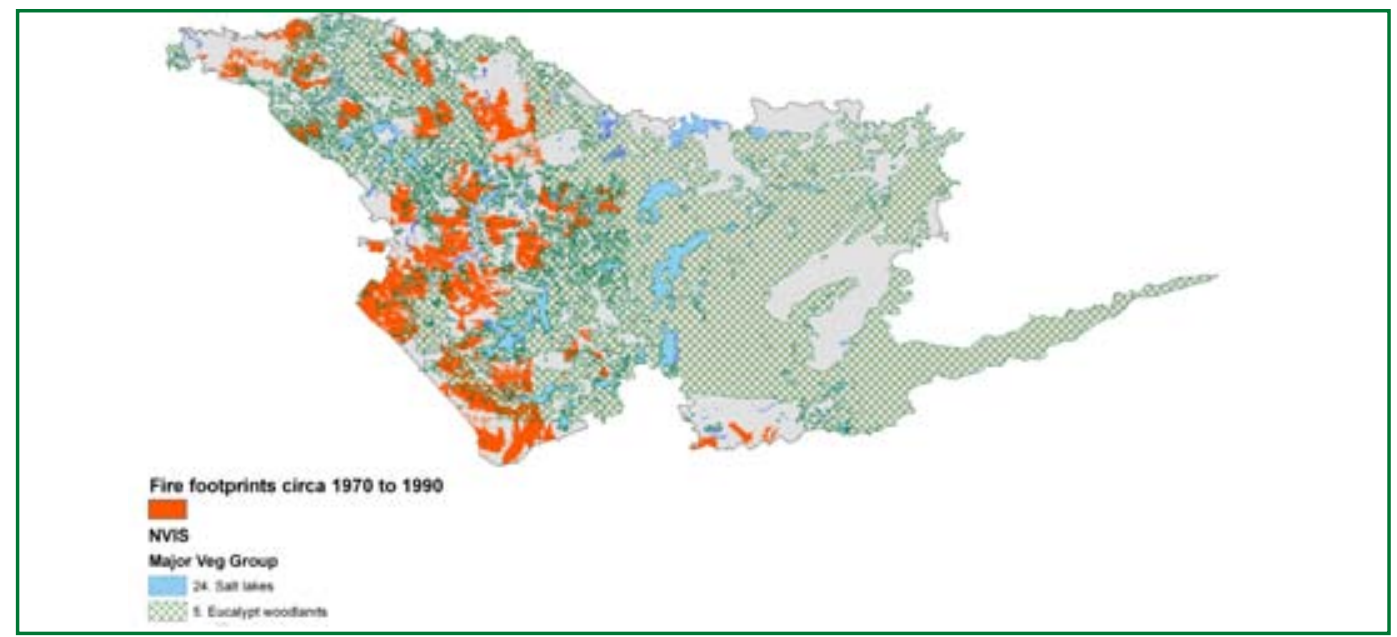

Figure $3.11 \mathrm{a}$

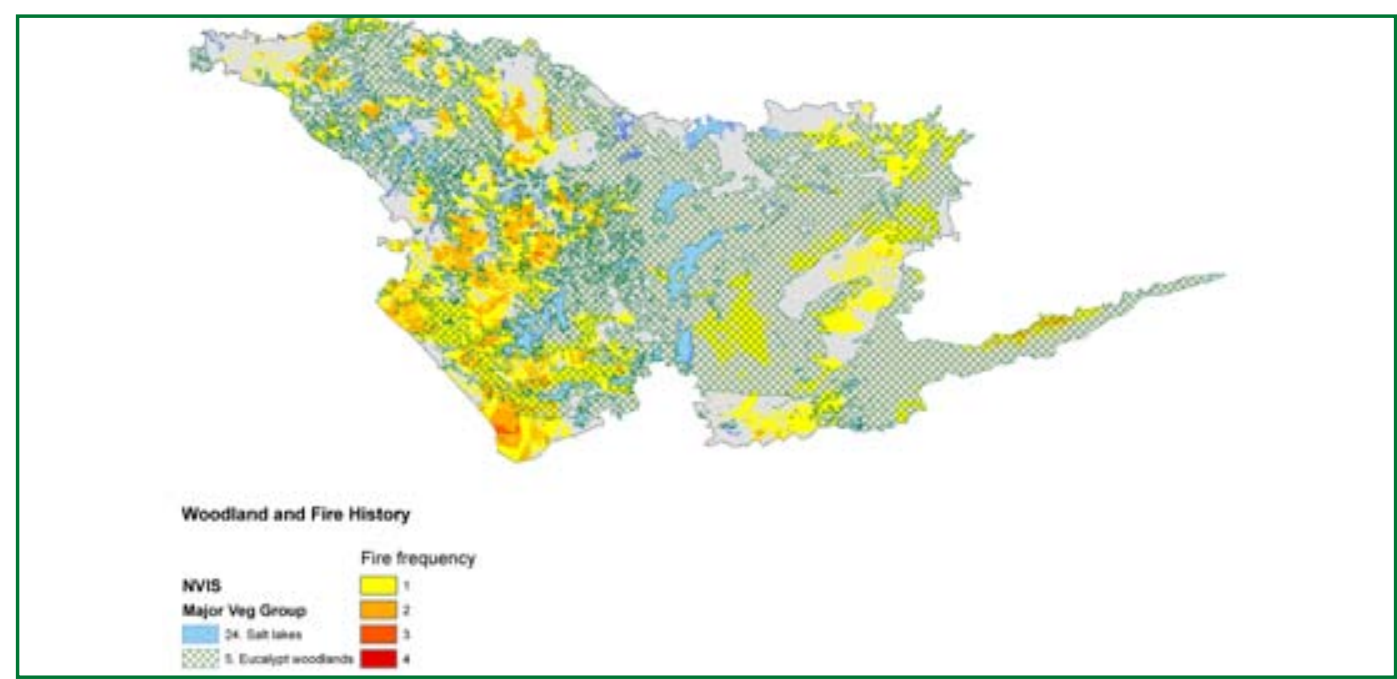

Figure $3.11 \mathrm{~b}$

Figures 3.11 Location of fire footprints identified from (a) Landsat satellite imagery for the period 1972-90, and (b) both Landsat and MODIS imagery for the period 1972-2007. The distribution of eucalypt woodland (NVIS MVG 5) is shown as an overlay.

These figures incorporate NVIS Version 3.0 data and Landsat Continental Mosaic (AGO) data that are Copyright Commonwealth of Australia 2005 and 2010.

8 As noted in Section 2.3 and Table A2, however, the derivation of the vegetation and surface geology layers for some map sheets relied on interpretation from aerial photographs, the surficial geology boundaries being inferred from vegetation cover. 
The example presented in Figure 3.12-an area that was disturbed by timber cutting between 50 and 100 years ago-also provides some evidence to support the proposition that eucalypt woodland can be replaced by shrubland dominated by single-stemmed eucalypts (marlock), mallee or acacia in the decades after intense fire. Eucalypt woodlands (MVG5) are mapped as occurring over a wide range of surface geology classes, with geology having considerable influence on the species represented (Table A3). In Figure 3.12, low closed forest/tall closed shrubland (MVG 15) vegetation mapping coincides with the mapping of the Czs (Cainozoic sands) geology class, while adjoining woodland vegetation is mapped on the Czg (Cainozoic gravel) geology. This correspondence between vegetation classes and geology classes is, however, not consistent across all of the map sheets. On some sheets, eucalypt woodland is mapped over Czs.

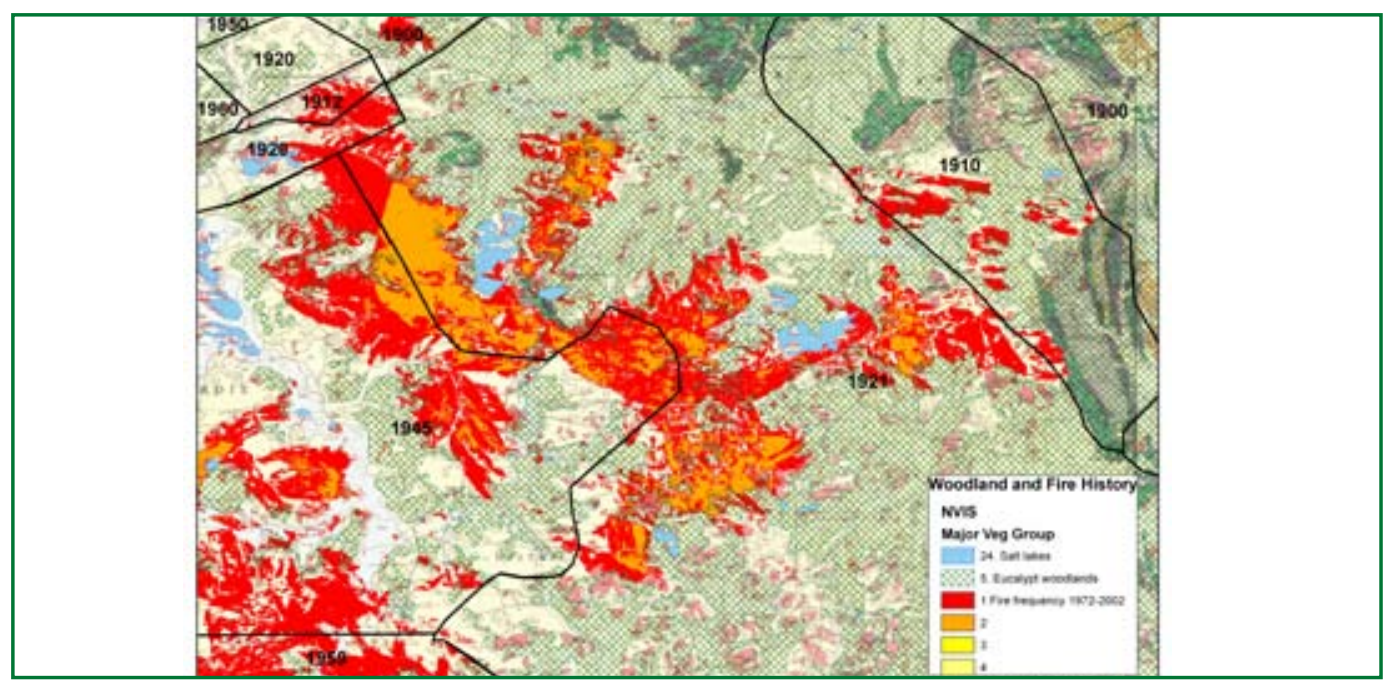

Figure 12a

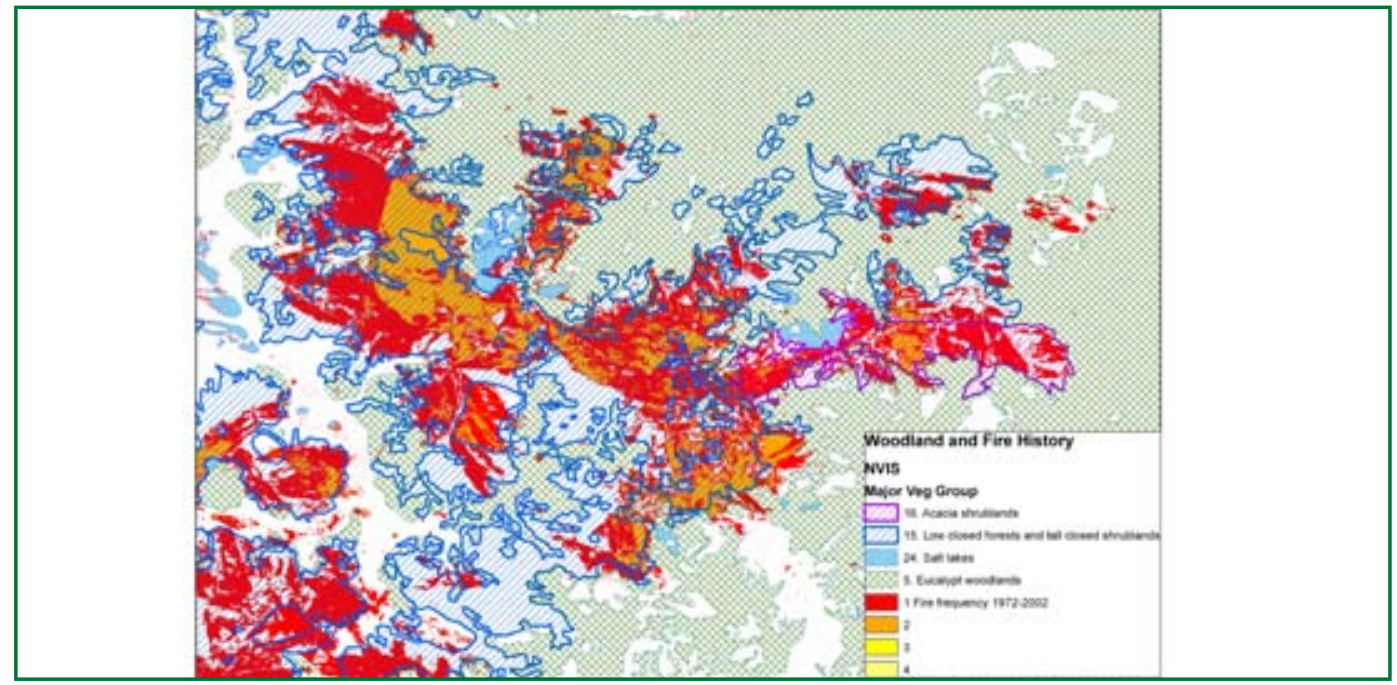

Figure 3.12b

Figures 12 Congruence between fire footprint and eucalypt woodland boundaries in part of the GWW. (a) The vegetation and fire layers are superimposed on the 1:250 000 surface geology map for Boorabbin. The entire area is mapped as being cut over for mining timber and/or fuel wood. The year in which timber cutting began within each section (outlined in black) is shown. (b) The extant vegetation over the fire footprint is mapped as shrubland (NVIS MVG 15 and 16).

Data source: see Table Al一Fire Mapping, Map Sheet, Geology, Timber cutting, MVG. This figure incorporates geology data that are Copyright State of Western Australia 2007, and NVIS Version 3.0 data and Landsat Continental Mosaic (AGO) data that are Copyright Commonwealth of Australia 2005 and 2010. 
Given the above, and as in the semi-arid GWW, the eucalypt seedlings and saplings making up the post-fire regeneration of woodland form a tall shrubland (MVG 15; Figure 3.9) for several decades following fire, we have 'updated' the mapped distribution of extant eucalypt woodland to account for the changes wrought by intense fires in the past 35 years by reclassifying the 1.46 million ha of MVG 5 (eucalypt forests and woodlands) vegetation that has been severely burnt by fires between 1972 and 2007 into MVG 15 (low closed forests and tall closed shrublands) (Figure 3.13).

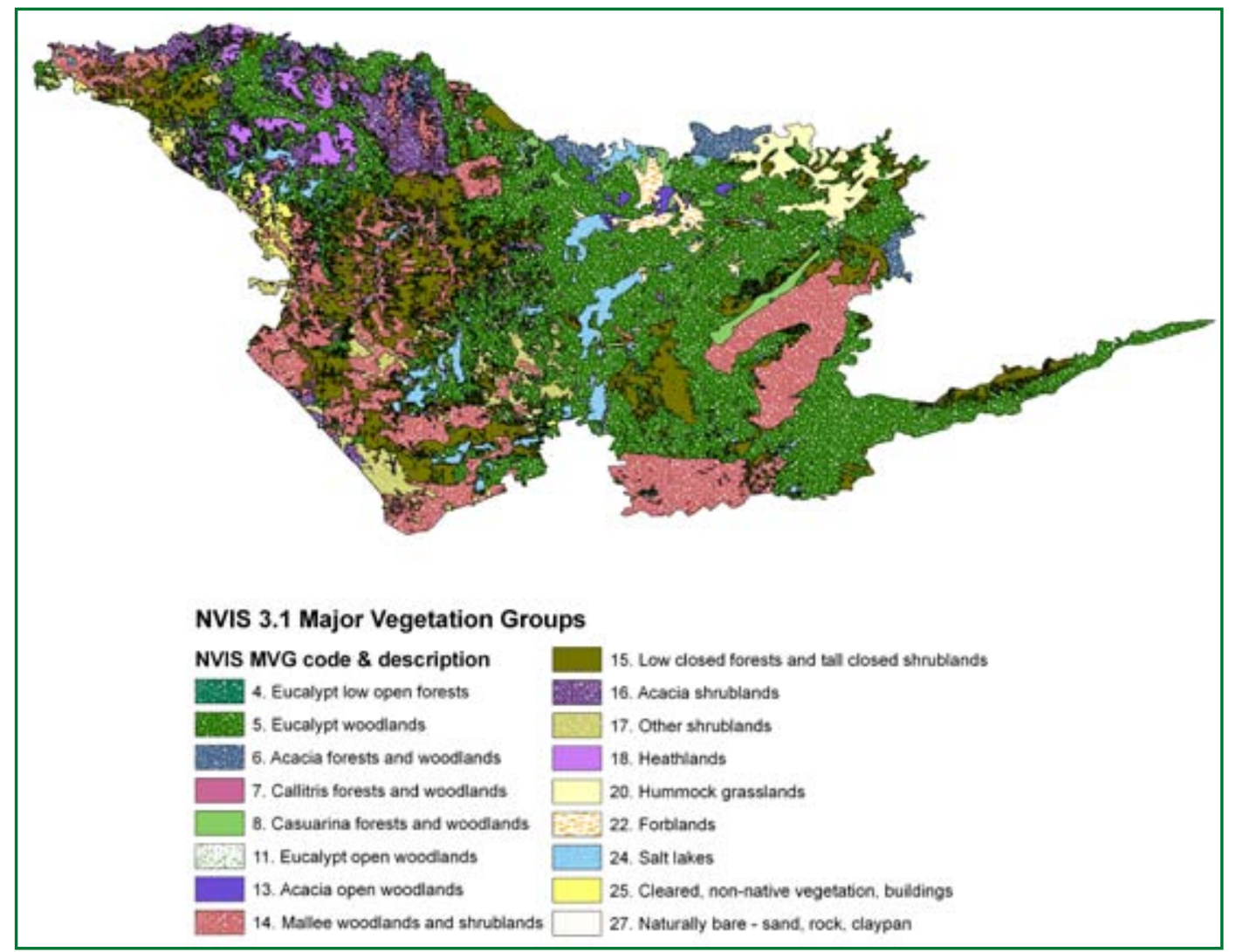

Figure 3.13 This map shows the likely current distribution of vegetation structural formations (NVIS MVGs) in the GWW in 2008. It was made by reclassifying the 1.46 million ha of NVIS MVGs 4 and 5 (eucalypt forests and woodlands) vegetation that have been severely burnt by fires between 1972 and 2007 into MVG 15 (low closed forests and tall closed shrublands) to better describe the structure of the post-fire regeneration of seedlings and root sprouts.

Data source: see Table Al-MVG. This figure incorporates NVIS Version 3.0 data that are Copyright Commonwealth of Australia 2005.

The mapping of fire footprints (Figure 3.11) is restricted to fires after 1972. Footprints of fires predating that time are, however, also evident in the Landsat satellite imagery. If we assume that the NVIS MVG classes that include Acacia and mallee woodlands and shrublands (MVGs 13, 14, 15 and 16) arise following intense fire in eucalypt woodlands and forests in the GWW, we can predict the extent of the latter in a 'no-fire' condition, and this is shown in Figure 3.14. In this scenario, the eucalypt woodlands occupy 13 million ha of the GWW-double the current extent. This estimate is likely greater than the actual extent of eucalypt woodland (MVG 5) structure pre-1750, as our scenario assumes no fire and no geological differences underlying the distributions of eucalypt woodlands and mallee formations. 


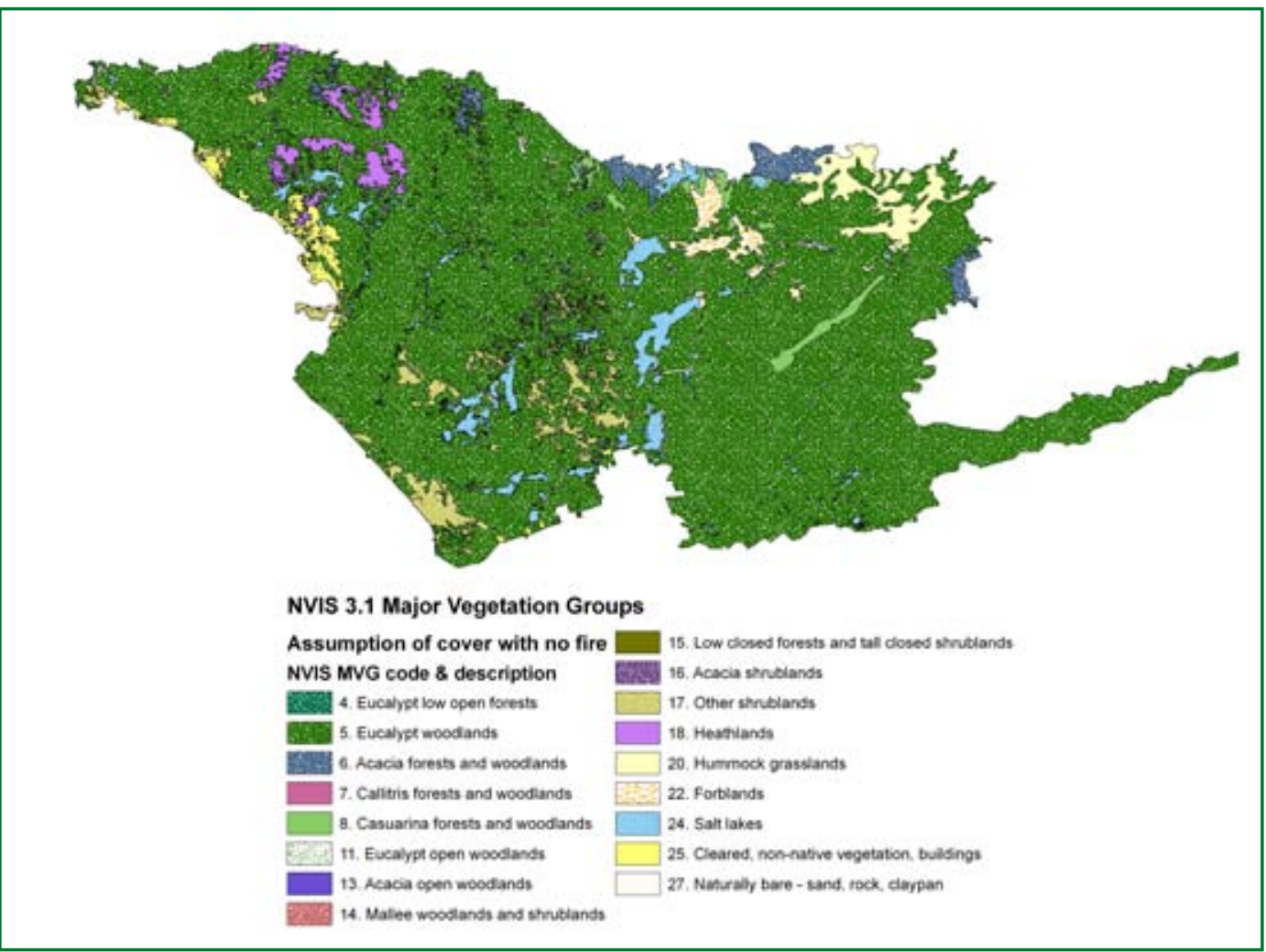

Figure 3.14 Predicted extent of eucalypt forest and woodland and other vegetation groups assuming fire was absent from the GWW for many decades to centuries and NVIS MVGs 13-16 occur at present in locations that were previously (that is, before a past fire event) eucalypt woodland (MVG 5). We subsequently refer to this hypothetical vegetation cover as the 'no-disturbance scenario'.

Data source: see Table Al-MVG. This figure incorporates NVIS Version 3.0 data that are Copyright Commonwealth of Australia 2005.

\subsubsection{Timber cutting}

The approximate location of timber-cutting activities in the GWW during the period 1900-75 (digitised from the map shown in Figure 2.12) is shown superimposed over the NVIS MVG layer in Figure 3.15. Timber cutting in this period affected approximately 4.4 million ha of vegetation in the GWW (Table 3.5). Historical records indicate that timber cutting in the GWW utilised mostly the salmon gum and gimlet woodlands (see Section 2.5). Following timber cutting, several species of eucalypt are able to regenerate from coppice (the authors have observed this at their field survey sites). The coppice growth arises from the top of the stump of the cut tree so that the original monopodial tree retains a monopodial base, which supports multiple stem sprouts. In contrast, mallee sprouts arise from the base of the stem to form a multi-stemmed shrub or tree.

According to our map (Figure 3.15) and Table 3.5, eucalypt woodlands (NVIS extant MVG 5 and 11) make up only 2.5 million ha of the timber-cutting area. However, 1.1 million ha of the area cut over for timber has a mapped vegetation cover class of mallee woodland and shrubland (MVG 14), tall closed shrubland (MVG 15) or acacia shrubland (MVG 16) (Table 3.5 and Figure 3.15). Half of the 1.1 million ha of MVGs 14,15 and 16 has subsequently been burned by intense fires. In Section 3.2.2, we proposed that MVGs 14 , 15 and 16 could represent pyric successional vegetation. If fire has altered the vegetation structure in this way following timber cutting then prior to timber cutting the vegetation 
cover could have been similar to the modelled vegetation cover shown in Figure 3.14. We show this modelled vegetation cover, beneath the timber-cutting overlay, in Figure 3.16. Under the 'no-disturbance' scenario, 3.6 million ha of eucalypt woodland would have been available for timber cutting circa 1900.

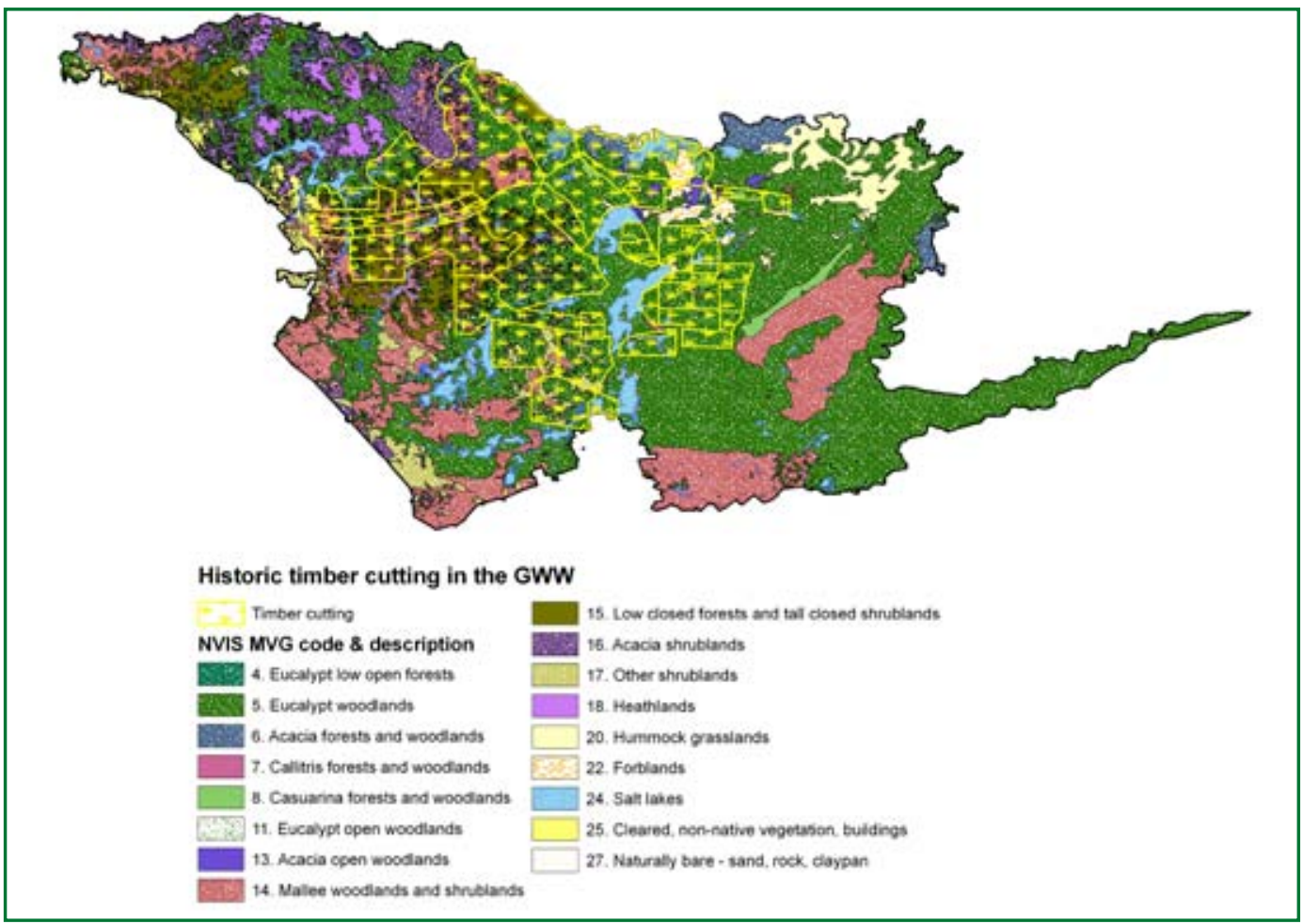

Figure 3.15 Extent of timber cutting in the GWW between 1900 and 1975 is shown as an overlay on the NVIS MVG extant vegetation layer.

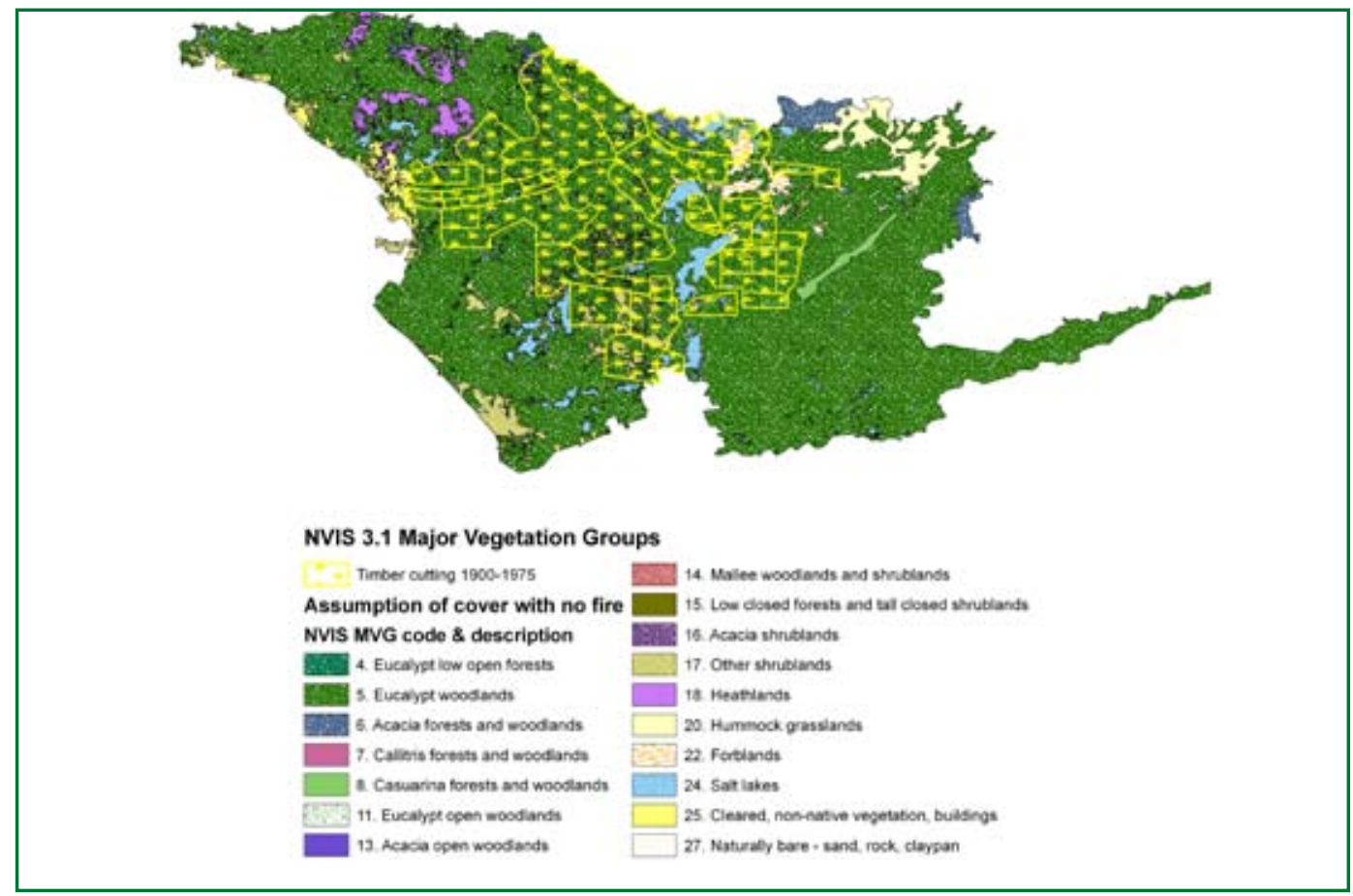

Figure 3.16 Extent of timber cutting in the GWW between 1900 and 1975 is shown as an overlay on the 'no-disturbance scenario' modelled vegetation layer (see Figure 3.14).

Data source: see Table Al-Timber cutting, MVG. These figures incorporate NVIS Version 3.0 data that are Copyright Commonwealth of Australia 2005. 
Table 3.5 Area within each NVIS MVG class for extant (Figure 3.15) and 'no-disturbance' (Figure 3.16) scenario vegetation, within the area mapped as affected by timber cutting between 1900 and 1975. The area of each vegetation type affected by both timber cutting and fire (1972-2007) is also shown.

\begin{tabular}{|c|c|c|c|}
\hline MVG class & $\begin{array}{c}\text { Area affected } \\
\text { by timber cutting } \\
\text { (ha) }\end{array}$ & $\begin{array}{l}\text { Area affected } \\
\text { by timber cutting } \\
\text { and fire (ha) }\end{array}$ & $\begin{array}{c}\text { Area affected } \\
\text { by timber cutting } \\
\text { (ha) }\end{array}$ \\
\hline & $\begin{array}{l}\text { NVIS extant } \\
\text { vegetation }\end{array}$ & $\begin{array}{l}\text { NVIS extant } \\
\text { vegetation }\end{array}$ & $\begin{array}{c}\text { Hypothetical } \\
\text { 'no-disturbance' } \\
\text { scenario }\end{array}$ \\
\hline 4. Eucalypt low open forest & 0 & 0 & 0 \\
\hline 5. Eucalypt woodlands & 2486560 & 167898 & 3614603 \\
\hline 6. Acacia forests and woodlands & 94515 & 833 & 94515 \\
\hline 7. Callitris forests and woodlands & 277 & 7 & 277 \\
\hline 8. Casuarina forests and woodlands & 117155 & 0 & 117155 \\
\hline 11. Eucalypt open woodlands & 5746 & 812 & 5746 \\
\hline 13. Acacia open woodlands & 21121 & 0 & 0 \\
\hline 14. Mallee woodlands and shrublands & 411304 & 117915 & 0 \\
\hline $\begin{array}{l}\text { 15. Low closed forests and tall closed } \\
\text { shrublands }\end{array}$ & 563713 & 341064 & 0 \\
\hline 16. Acacia shrublands & 131905 & 63790 & 0 \\
\hline 17. Other shrublands & 204881 & 46961 & 204881 \\
\hline 18. Heathlands & 4734 & 285 & 4734 \\
\hline 20. Hummock grasslands & 4418 & 3601 & 4418 \\
\hline 22. Forblands & 74505 & 1268 & 74505 \\
\hline 24. Salt lakes & 119874 & 5098 & 119874 \\
\hline 25. Cleared, non-native vegetation & 11816 & 3607 & 11816 \\
\hline 27. Naturally bare-sand, rock, claypan & 115472 & 25721 & 115472 \\
\hline Total & 4367997 & 778859 & 4367997 \\
\hline
\end{tabular}




\subsubsection{Mining and mineral exploration}

Most of the mining and mineral exploration in the GWW is located within the boundaries of the greenstone lithological unit (Figure 2.6). The area impacted by open-cut mining could be relatively small. Mineral exploration has, however, more profound impacts on the vegetation including the use of vehicles off-road to access remote country, construction of access tracks, excavations to expose deeper soil horizons, construction of seismic lines and the cutting down and removal of wood for fuel, mine-props, and so on (see Plates 1-5). A map showing the location of the major lithological units and the land tenure type is presented in Figure 3.17. A large portion of the granite-greenstone lithological unit is under leasehold tenure and is used for mining and mineral exploration.

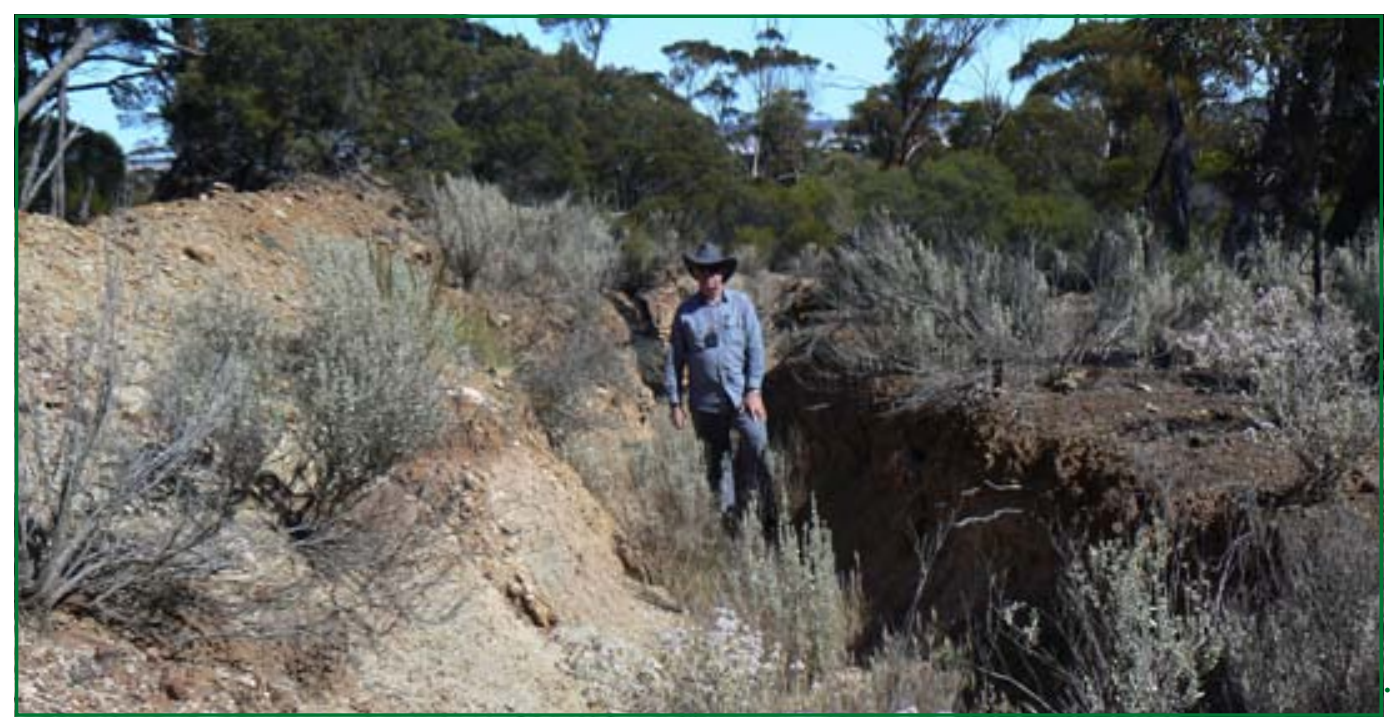

Plate 1 Professor Brendan Mackey, ANU, standing in a typical trench created during mineral exploration, GWW.

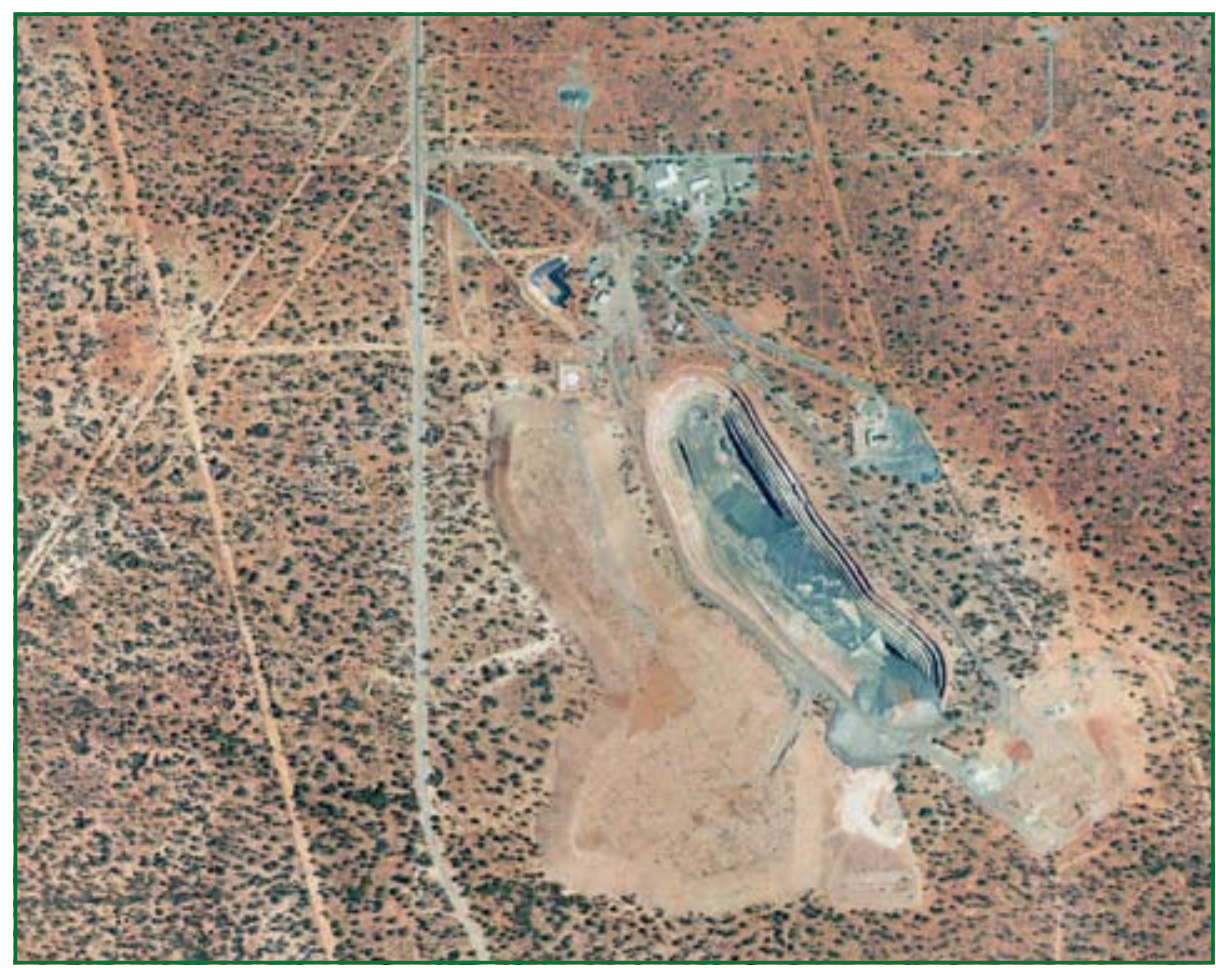

Plate 2 Aerial photograph of an open-cut mine site, GWW.

Reproduced by permission of WA Land Information Authority, CL34/2010 (<www.landgate.wa.gov.au>). 


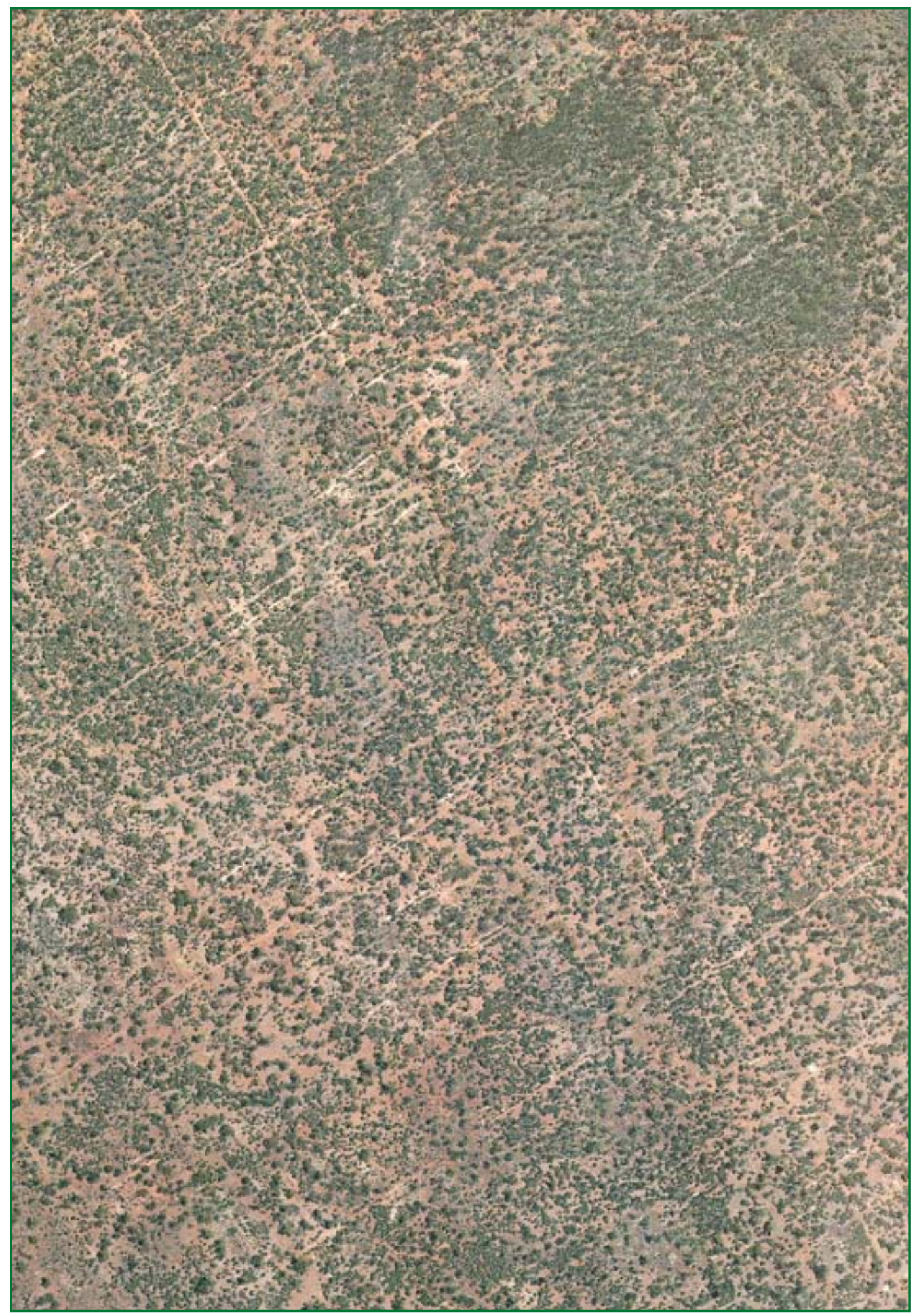

Plate 3 Seismic tracks near sites 13 and 14, GWW.

Reproduced by permission of WA Land Information Authority, CL34/2010 (<www.landgate.wa.gov.au>). 


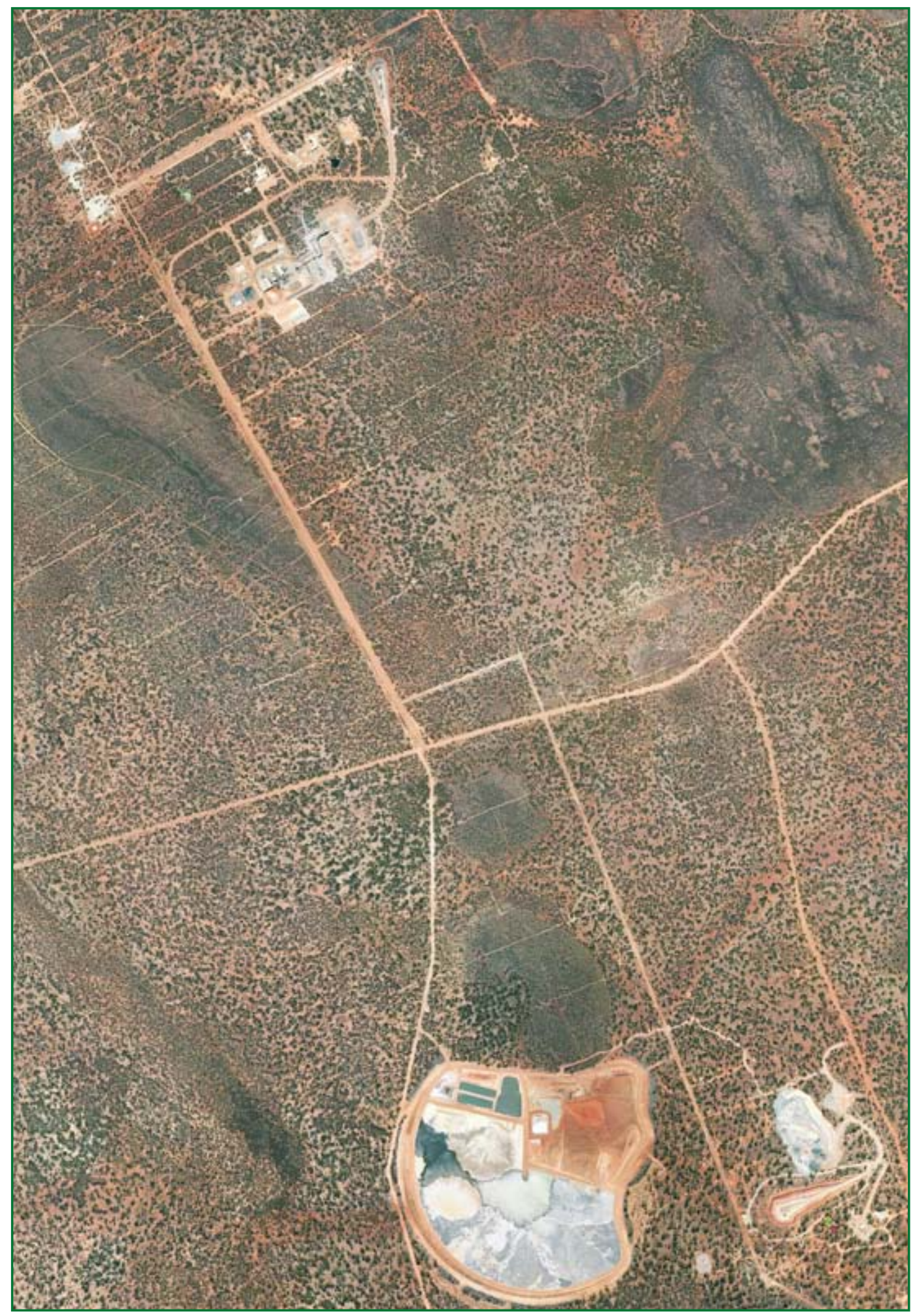

Plate 4 Aerial photograph showing the environmental footprint of a nickel mine, GWW.

Reproduced by permission of WA Land Information Authority, CL34/2010 (<www.landgate.wa.gov.au>). 


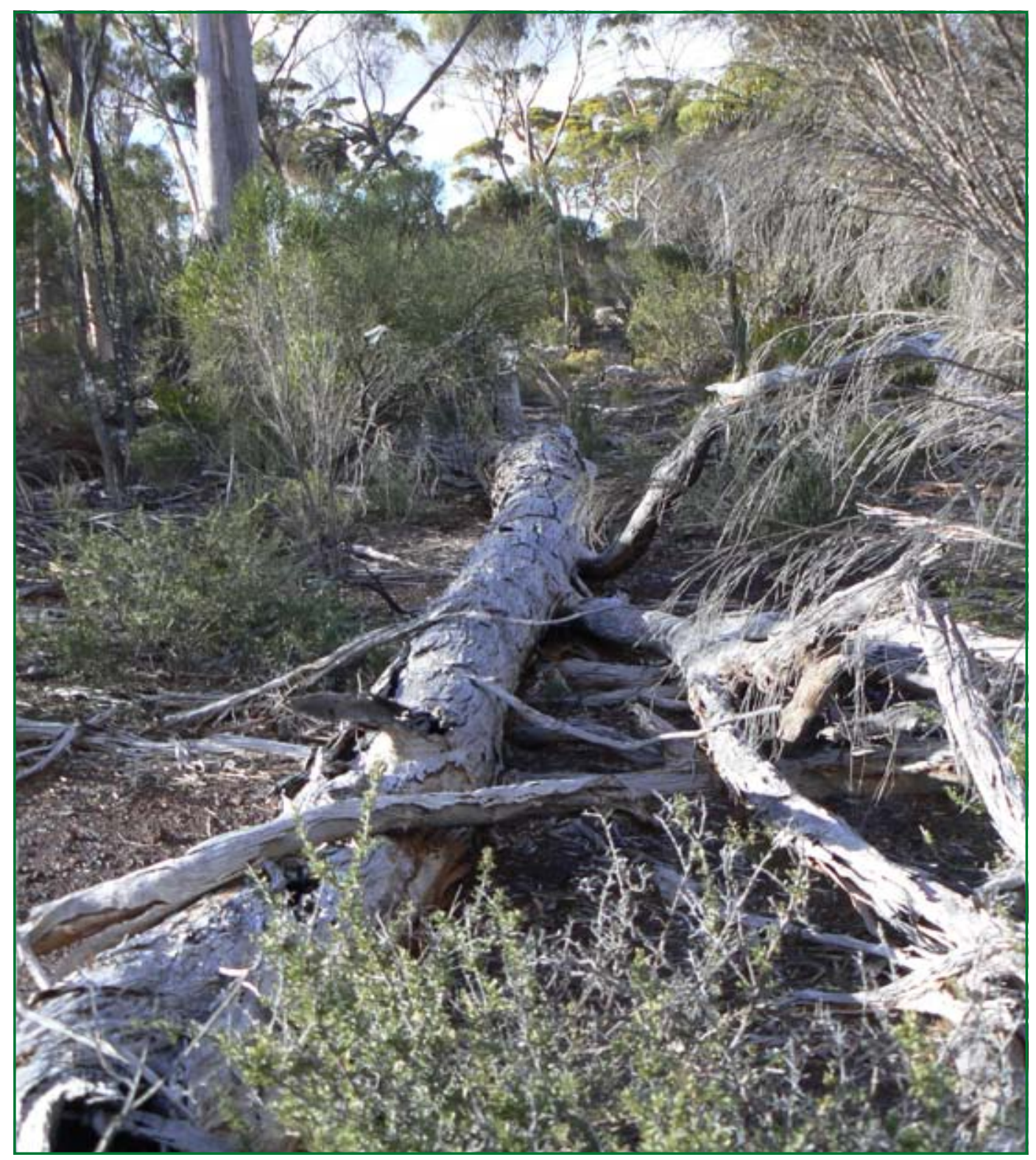

Plate 5 Stump and felled tree, Site 14. Several trees had been felled at this remote site located on the greenstone belt.

\subsubsection{Land tenure}

Four types of land tenure predominate in the GWW: vacant crown land ( 55 per cent), nature conservation reserve (10 per cent), Aboriginal leasehold (1.5 per cent) and other leasehold (20 per cent) (see Figure 3.17). The area of coverage of each land tenure type, the land tenure of the extant eucalypt woodland and the land tenure of the mapped fire footprint (Figure 3.8) are given in Table 3.6. Thirty-two per cent of the extant woodland (as mapped in Figure 3.13) occurs on leasehold land, while 55 per cent is on vacant crown land and 9 per cent is within nature conservation reserves. Some land tenure types appear to be more prone to fire and approximately 36 per cent of the vacant crown land, nature conservation reserve and Aboriginal reserve classes bear a fire footprint (1972-2007 fire events) in contrast with 6 per cent of leasehold land. The lesser fire footprint on leasehold land could be a consequence of: 1) less fuel due to land clearing and grazing; 2) fire protection and suppression to protect economic assets; and/or 3) fewer ignition events due to restricted access. 
For the purpose of carbon accounting, it was necessary to determine if the vegetation structure (and biomass) has been modified by land clearing on different land tenures in addition to the mapped timber cutting (area of timber cutting shown in relation to land tenure in Figure 3.17). As all of our field study sites were located on vacant crown land or within nature conservation reserves, we needed to utilise other data sources to assess the vegetation cover and biomass of leasehold land. To do this, we utilised remotely sensed imagery, as discussed in Section 3.3 below. Nonetheless, it is evident from Figure 3.17 that most of the land under leasehold tenure overlies granite-greenstone lithology (thus is likely to have been impacted on by mineral exploration) and/or has been subjected to timber cutting.

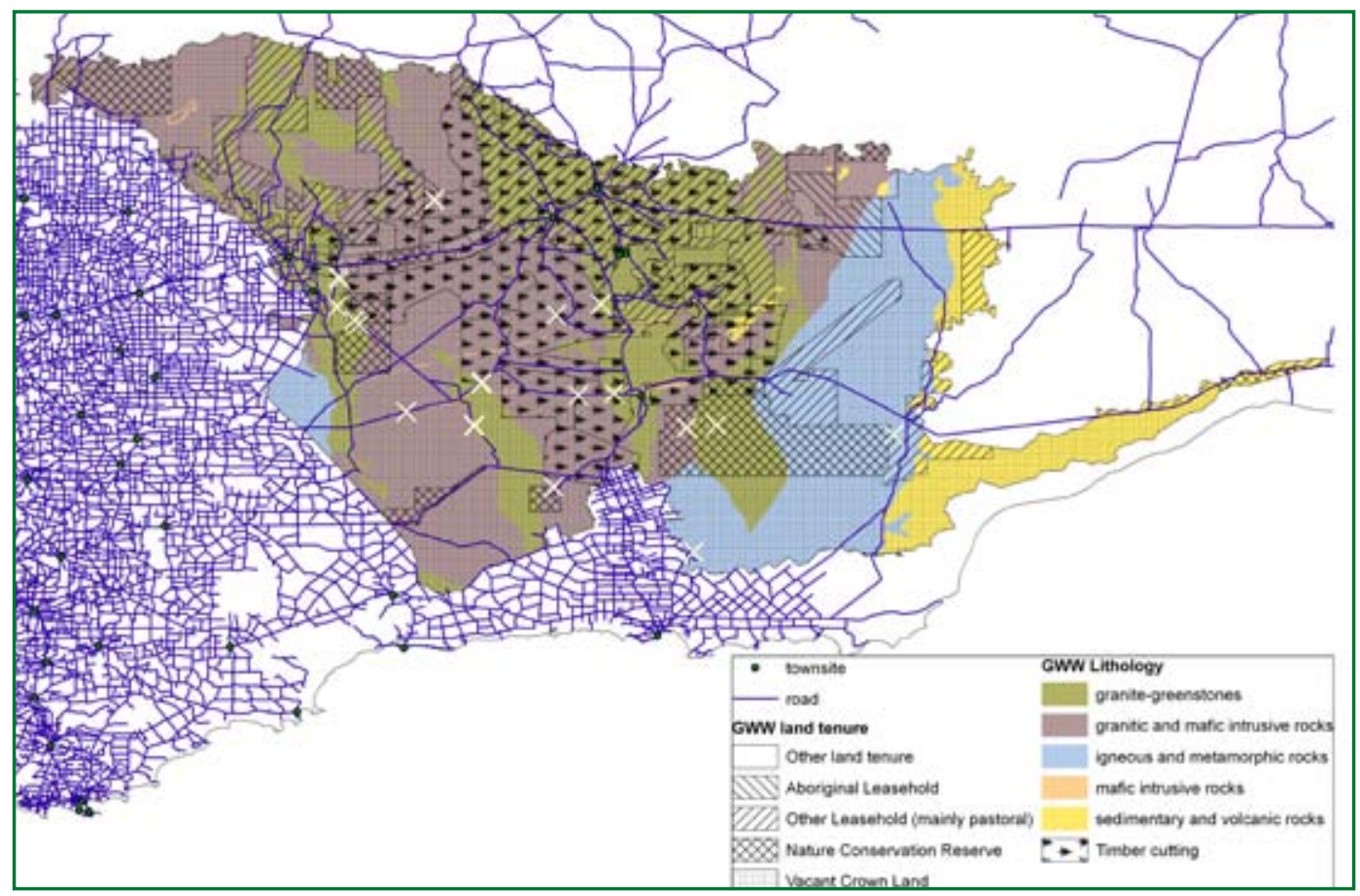

Figure 3.17 Overlay showing location of timber cutting superimposed on land tenure and lithology layers (Figure 2.6).

Data source: see Table A 1 - Timber cutting, Land Tenure, Lithology, Roads, Towns. This figure incorporates geology and road location data that are Copyright State of Western Australia 2007, and Australian land tenure (1993) and population centre data that are Copyright Commonwealth of Australia 1993 and 1998.

Table 3.6 Areal extent of land tenure types within the entire GWW, within the area mapped as woodland and within the area mapped as having a fire footprint between 1972 and 2007 (see Figure 3.8).

\begin{tabular}{l|r|r|r}
\multicolumn{1}{c}{ Land tenure type } & $\begin{array}{c}\text { Total area } \\
(\text { ha } \times 1000)\end{array}$ & $\begin{array}{c}\text { Woodland } \\
\text { area } \\
(\text { ha } \times 1000)\end{array}$ & $\begin{array}{r}\text { Total area burnt } \\
1972-2007 \\
(\text { ha } \times 1000)\end{array}$ \\
\hline 1. Aboriginal reserve & 108 & 29 & 39 \\
\hline 2. Aboriginal leasehold & 252 & 170 & 42 \\
\hline 3. Forestry reserve & 120 & 88 & 3 \\
\hline 4. Other freehold & 249 & 16 & 13 \\
\hline 5. Other leasehold & 3513 & 2072 & 204 \\
\hline 6. Mixed & 9 & 9 & 0 \\
\hline 7. Nature conservation reserve & 1651 & 605 & 590 \\
\hline 8. Other & 160 & 104 & 3 \\
\hline 9. Vacant crown land & 9859 & 3809 & 3493 \\
\hline 10. Water reserve & 44 & 11 & 4 \\
\hline
\end{tabular}




\subsubsection{Overview of disturbance impacts}

Our analyses of the available spatial data in this chapter have revealed that most of the GWW has experienced disturbance from the mining industry through minerals exploration and timber cutting, from clearing or thinning of the vegetation for cropping and grazing or from intense fire (Figure 3.18). All of these disturbances must be taken into account when extrapolating from field-based measurements of the biomass carbon stock to the entire GWW.

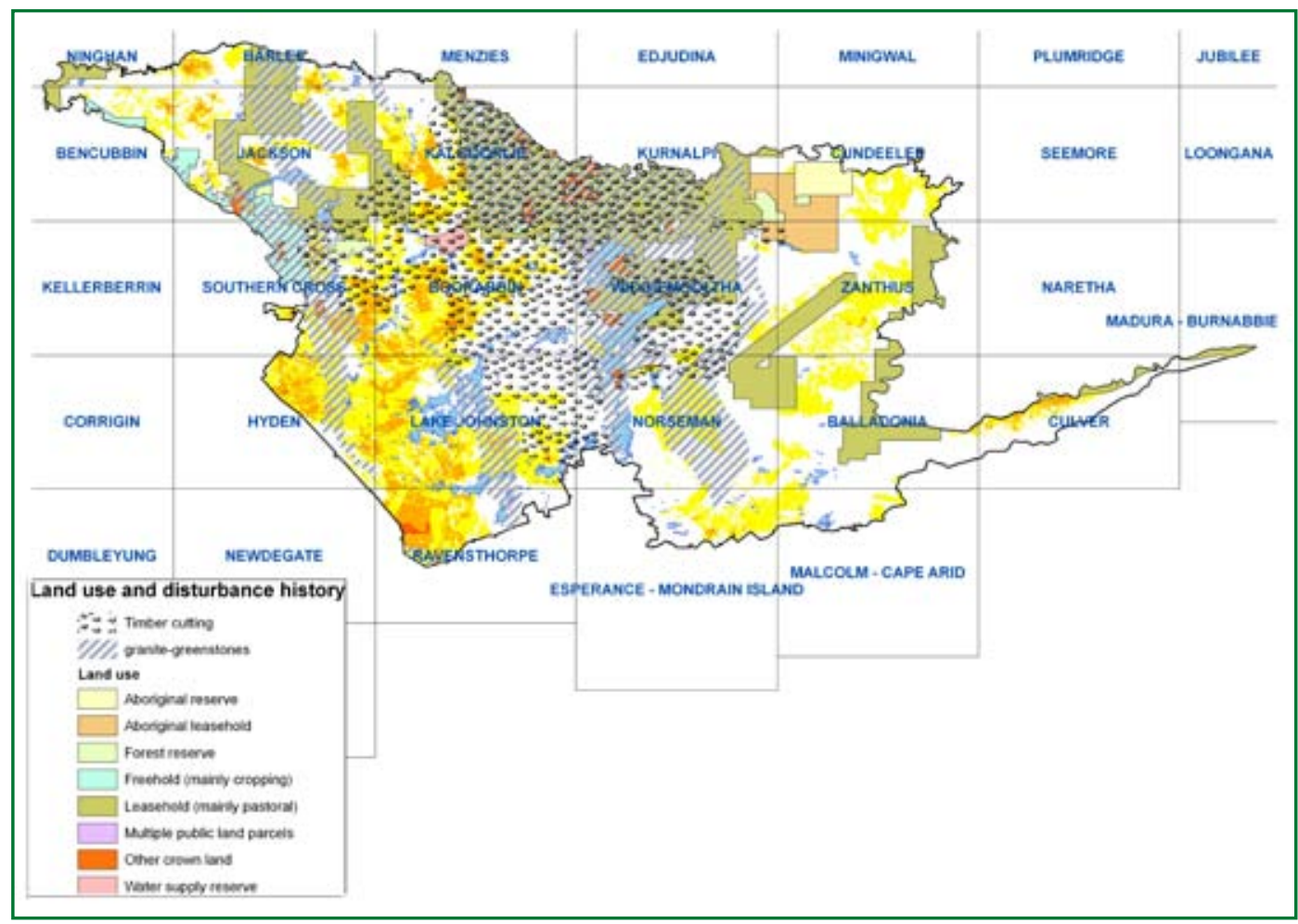

Figure 3.18 This map shows the extent of direct (timber cutting, minerals exploration and land-use change since 1900) and indirect (fire between 1972 and 2007) disturbances in the GWW. The legend for the fire footprints is shown in Figure 3.8.

Data source: see Table Al-Timber cutting, Land Tenure, Lithology, Map sheet. This figure incorporates geology and map sheet Index250 data that are Copyright State of Western Australia 2007, and Australian land tenure (1993) data that are Copyright Commonwealth of Australia 1993.

\subsubsection{Relationship between land use/disturbance and AGB estimates for field survey sites}

There is evidence that fire has had a larger effect than timber cutting on the aboveground biomass (AGB) at the ANU field survey sites (see Figure 3.19). The AGB of all field survey sites that have been burnt by intensive fire since 1972 is low. AGB of the ANU woodland sites that have been cut over is, however, more comparable with that of most of the other woodland sites. Further field surveys are needed to identify whether these relationships hold more broadly across the GWW, along with data on AGB values before and post-timber cutting. The field survey sites having the highest AGB occur in woodland where there has been no timber cutting, no fire since 1972 and no mining activity (that is, not on granite-greenstone lithology). 


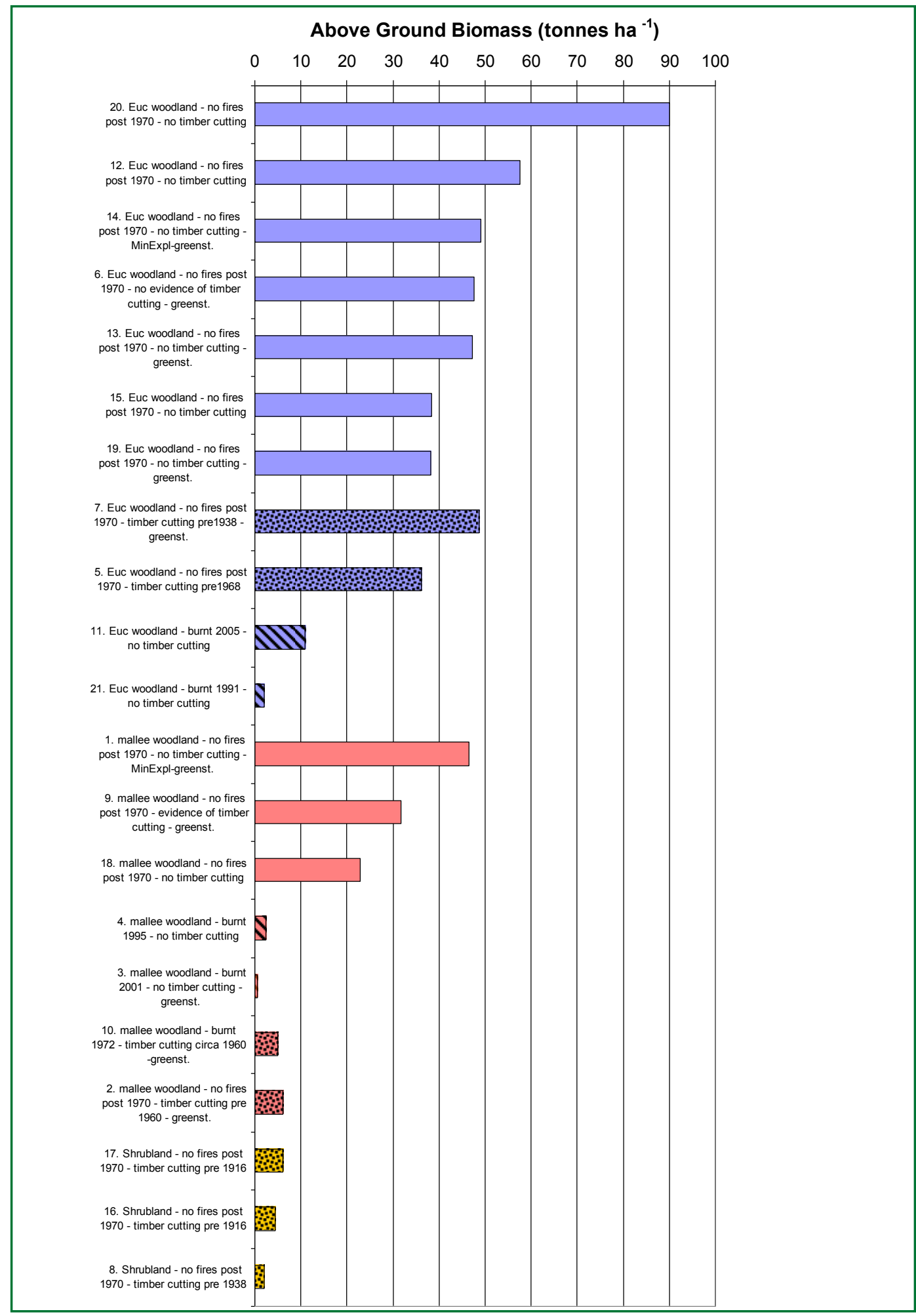

Figure 3.19 Relationship between NVIS MVG vegetation class, fire history (post 1970), timbercutting history (1900-75), surface lithology and AGB of ANU field survey sites (numbered 1-21). Fire, timber-cutting histories and lithology are inferred from the spatial data layers and field observation. The lithology is indicated only for sites occurring on the granite-greenstone formation, indicated here by 'greenst'. Our field notes record impacts of prospecting (vehicle tracks, excavations, and so on) on or close to many sites located on the granite-greenstone lithology. Although our timber-cutting spatial data layer indicated that Site 6 had been cut over, we could find no evidence of this activity having occurred. There were large trees present and no cut stumps or coppice growth. 


\subsection{EXTRAPOLATION OF CARBON STOCKS FROM SITE DATA}

In the preceding section, we investigated the extent of disturbance by fire, timber cutting and mineral exploration in the GWW and identified those field survey sites that had been impacted on by these factors. Variability in the availability of water and nutrients across the GWW also affects foliage cover and must be taken into account when extrapolating from field survey sites to other locations.

\subsubsection{Remote sensing of foliage cover}

Spatial information about the green foliage cover of woody evergreen vegetation can be obtained through the analysis of time-series of satellite imagery (Berry and Roderick 2002; Roderick et al. 1999). We derived a spatial layer depicting the fraction of photosynthetically active radiation intercepted by the evergreen vegetation canopy $\left(F_{E}\right)$ from MODIS 16-Day L3 Global 250m (MOD13Q1) satellite imagery for the period from July 2000 to July 2005 (Berry et al. 2007)?

The first step in the calculation of $F_{E}$ involved the calculation of monthly values of the normalised difference vegetation index (NDVI). We then calculated the fraction of photosynthetically active radiation intercepted by the sunlit vegetation canopy $\left(F_{\text {PAR }}\right)$ for all months in the time-series using the following equation:

$$
\begin{aligned}
& F_{P A R}{ }^{*}=1.118 N^{\prime} V I^{*}-0.168 \text { in which } N D V I^{*} \geq 0.15 \\
& \text { and } F_{P A R}{ }^{*}=0 \text { in which } N D V I^{*}<0.15
\end{aligned}
$$

in which '*' indicates a value for a specific month and year. We assumed that when NDVI $<0.15$ the surface cover is bare soil or rock. In any month, $F_{\text {PAR }}$ will comprise a persistent evergreen component $\left(F_{E}\right)$ due mostly to woody vegetation (Roderick et al. 1999) and a fluctuating seasonal component $\left(F_{R}\right)$-the green-flush following rain that is due mostly to herbaceous vegetation. To separate these components, we followed the general method of Donohue et al. (2009), but applied a 12-month moving minimum window and a 15-month smoothing function. We then determined the 12-month period from January 2001 to December 2004 for which $F_{E}$ was at its maximum value and calculated a 12-month average $F_{E}$. This approach was taken in order to reduce the 'noise' from shortterm defoliation events. The resulting spatial layer of average $F_{E}$ is shown in Figure 3.20.

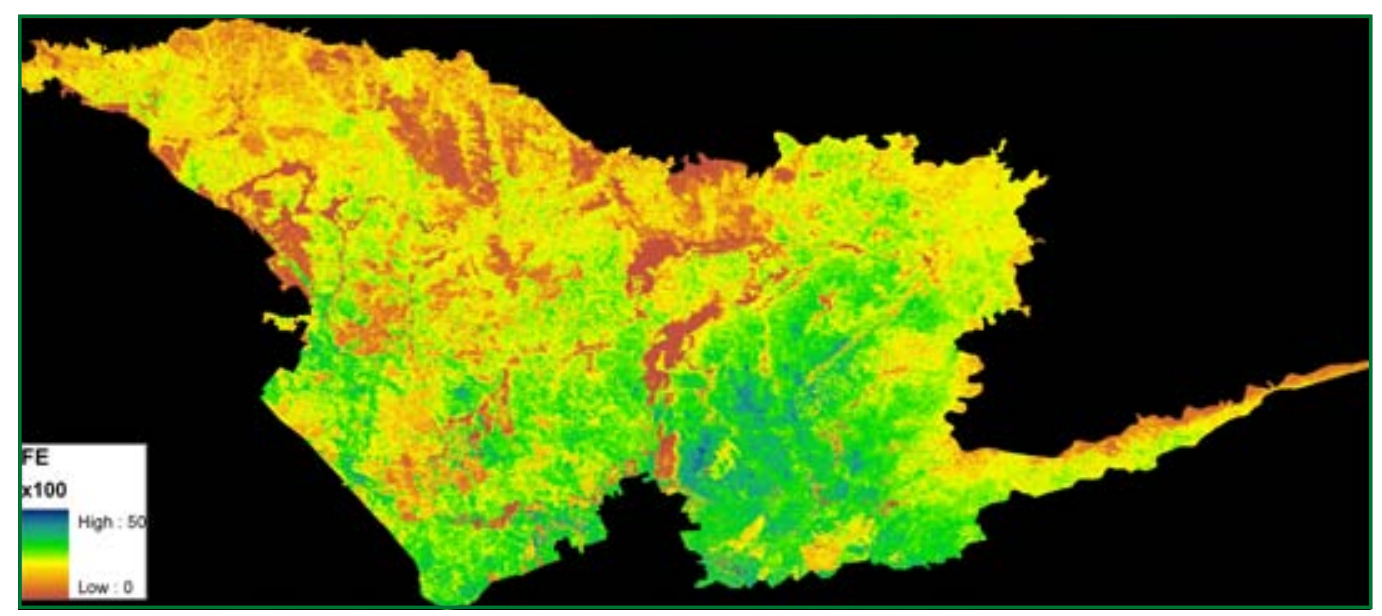

Figure 3.20 Fraction of photosynthetically active radiation intercepted by the evergreen component of the vegetation canopy $\left(F_{E}\right)$. Units: $x$ 100. Land cover types having low $F_{E}$ include salt lakes, rock outcrops, agricultural land and vegetation canopies that have been thinned by fire or land clearing.

9 For data source for MODIS data, see Table A1-MODIS. 


\subsubsection{Relationship between foliage cover and AGB}

The variable $F_{E}$ provides information about the density of green foliage cover but not vegetation height, hence a direct relationship to biomass cannot be assumed. Over large environmental gradients and wide-ranging vegetation types, this relationship is a reasonable assumption because the environmental factors that influence canopy cover also influence height and biomass. Our field data for the GWW demonstrated, however, the lack of a general relationship between $F_{E}$ and biomass: $F_{E}$ of shrubland sites ranged from 0.04 to 0.37 and eucalypt woodland sites from 0.22 to 0.32 . Thus, there were shrubland sites with canopies as densely green as some woodland sites. Within these two broad vegetation groups and woodland disturbance categories, however, relationships between $F_{E}$ and $A G B$ were evident. We found that although many of our woodland sites had very similar $F_{E}$ values, sites that had been disturbed by timber cutting or mineral exploration had lower AGB than undisturbed woodland sites. This finding indicates that the canopy (comprising leaves supported by small branches) at disturbed sites has had sufficient time to recover to the pre-disturbance condition, while the mass (and volume) of woody stems that support the canopy remain below the pre-disturbance condition. We derived four equations to predict $A G B\left(\dagger \mathrm{ha}^{-1}\right)$ from $F_{E}$ (expressed as a percentage) in the GWW (see Figure 3.21). Three of these equations predict the AGB of eucalypt woodlands (NVIS MVG 4 and 5) for the three scenarios

i) no timber cutting, no mineral exploration disturbance (Equation 3.8)

\section{Equation 3.8}

$A G B=0.0841 \mathrm{~F}_{E}^{2}$

ii) mineral exploration, no timber cutting (Equation 3.9)

\section{Equation 3.9}

$A G B=0.0597 \mathrm{~F}_{E}^{2}$

iii) timber cutting (Equation 3.10)

\section{Equation 3.10}

$A G B=0.0441 \mathrm{~F}_{E}^{2}$

The fourth equation predicts $A G B$ for all other woody vegetation classes of heath, mallee, marlock and shrub (Equation 3.11).

\section{Equation 3.11}

$A G B=0.06 F_{E}^{1.642}$

All of the equations above have been forced through $(0,0)$ although the line of best fit for scenario (i) would pass through a point where $F_{E}$ exceeds 0 when $A G B$ equals $0-a$ condition where a small woody vegetation canopy exists with no mass. In the case of scenarios (ii) and (iii), the line of best fit is plotted through a group of three points. The scatter between points is likely due to the variable impacts of mineral exploration and timber cutting at these sites. These activities have occurred over a long period (75 years in the case of timber cutting). Both the time period since disturbance and the intensity of disturbance affect AGB. It is not possible to develop more specific equations without the availability of detailed information describing these past disturbances and a greater number of field survey sites within each disturbance class. For our field sites, the effect of disturbance on biomass was greater than the influence of other environmental variables. More field data would be required to calibrate the effect of other environmental variables within disturbance classes. 


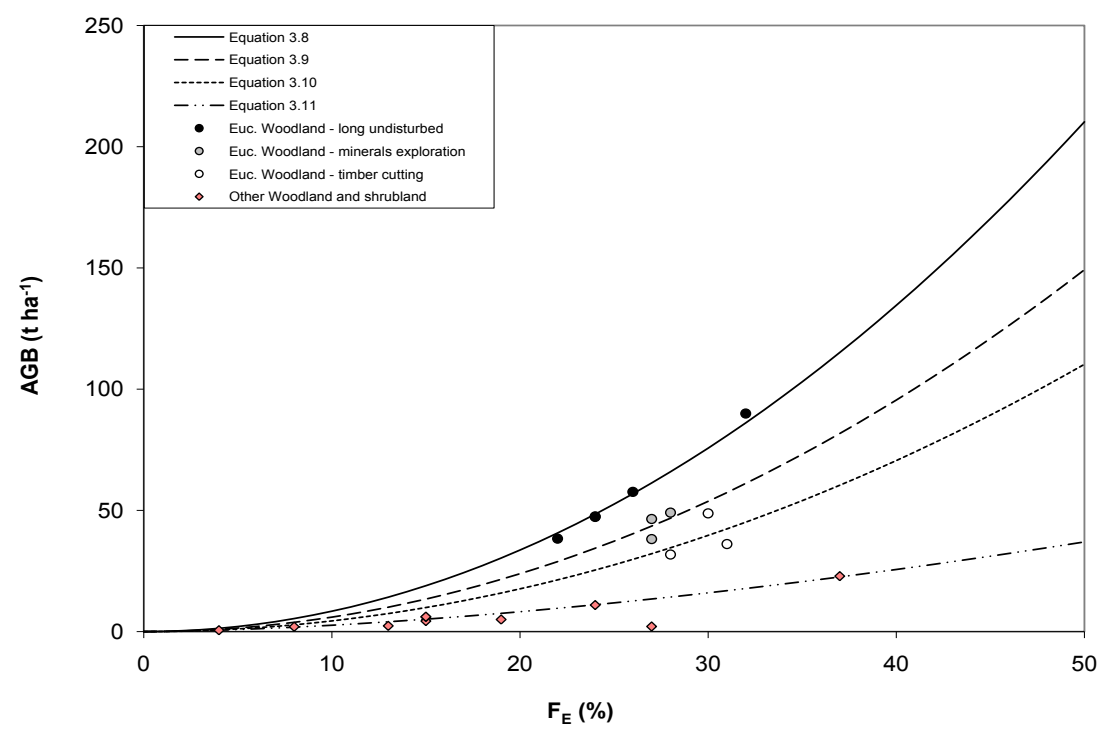

Figure 3.21a

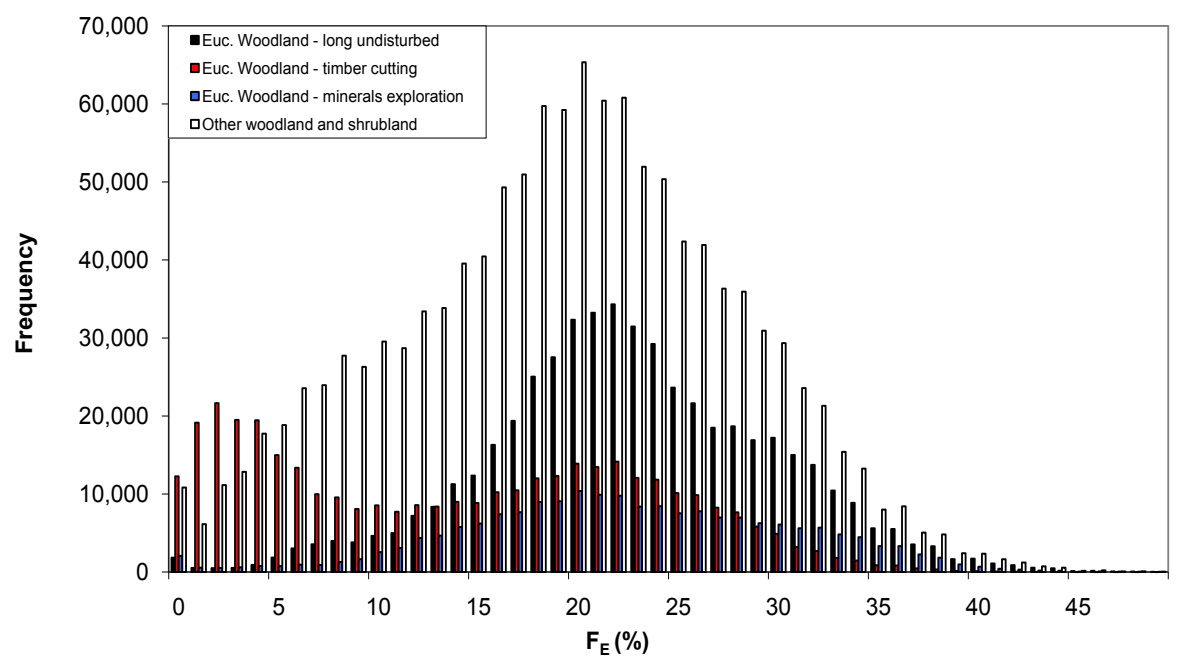

Figure 3.21b

Figures 3.21 Relationships between above-ground biomass ( $A G B, t$ ha ${ }^{-1}$ ) and $F_{E}$ for the 21 field sites. $F_{E}$ values for the field sites were extracted from the spatial data layer shown in Figure 3.20. Equations 3.8-3.11 (see 'Vegetation-Remote Sensing' section) are also plotted. One equation is suitable for predicting the AGB of all vegetation structures other than eucalypt woodland. (b) The frequency histogram shows the distribution of $250 \mathrm{~m} \times 250 \mathrm{~m}$ grid cells within $F_{E}$ classes for each of the AGB scenarios. The open bars indicate the maximum value of $F_{E}$ of field sites within the 'Other woodland and shrubland' class. The black, blue and red bars indicate the maximum values of $F_{E}$ of the eucalypt woodland classes. 
We tested the capacity of Equations 3.8-3.11 to predict AGB by plotting the predicted values against those derived from measurements for our 21 field survey sites (Figure 3.22). Overall, there was good agreement between the actual and predicted values $\left(A G B_{\text {predicted }}=0.99 A G B_{\text {actual }} ; R^{2}=0.93\right)$.

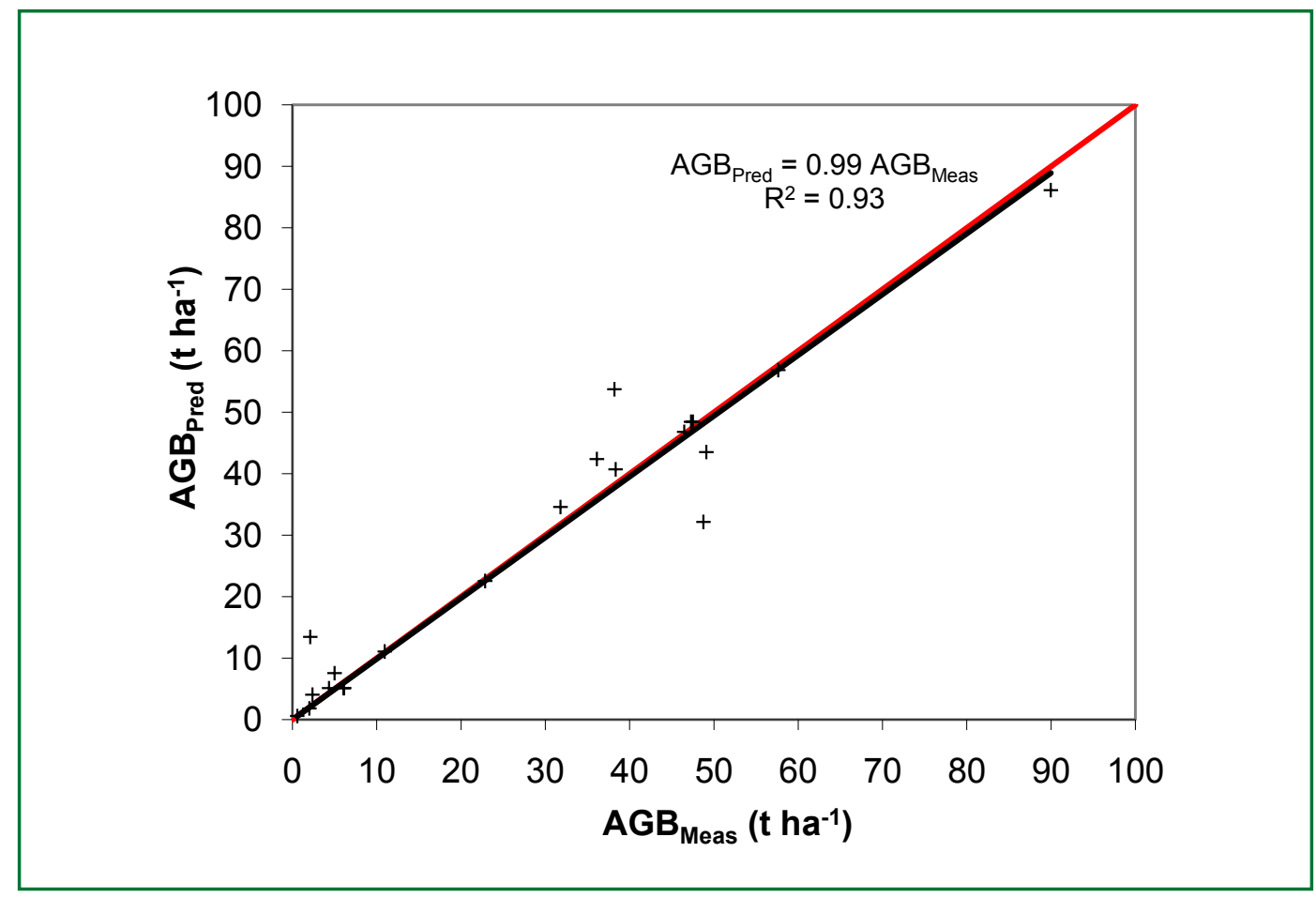

Figure 3.22 Comparison of site $A G B$ calculated from field data $\left(A G B_{\text {Meas }}\right)$ with values predicted using the Equations 3.8-3.11 ( $A G B_{\text {pred }}$ ). The lines show the line of best fit using a linear regression analysis (black) and the 1:1 relationship (red).

We noted above that the range of $F_{E}$ for eucalypt woodlands in our field survey was from 0.22 to 0.32 . The range of $F_{E}$ for areas mapped as woodland in Figure 3.13, however, varies from 0 (no evergreen vegetation) to 0.5 (Figure 3.23). Those areas having very low values of $F_{E}$ are under leasehold land tenure. As noted above (Section 3.2.5), most of the woodland under leasehold tenure has been subjected to mineral exploration and/ or timber cutting-disturbances accounted for by scenarios (ii) and (iii). Low values of $F_{E}$ can arise if regeneration of woodland has been suppressed by management actions that might also have resulted in further land clearing. We utilised Google Earth and high-resolution aerial photographs to investigate the density of woodland tree cover on land under leasehold tenure. One such area is shown in Plate 6. In this example, the woodland has evidently been thinned or cleared (in the south-western corner of the photo) for pastoralism. Plate 7 shows a further example of woodland on land that was formerly under pastoral leasehold tenure but is currently within a nature conservation reserve. The woodland has been thinned rather than cleared. The range in $F_{E}$ for woodlands over the GWW (max. 0.5) exceeds the $F_{E}$ values for the field sites (max. 0.32); hence predictions of $A G B$ will exceed the calibration data for the equations. For other woody vegetation types, the range in $F_{E}$ at the field sites is similar to the full range over the GWW. 


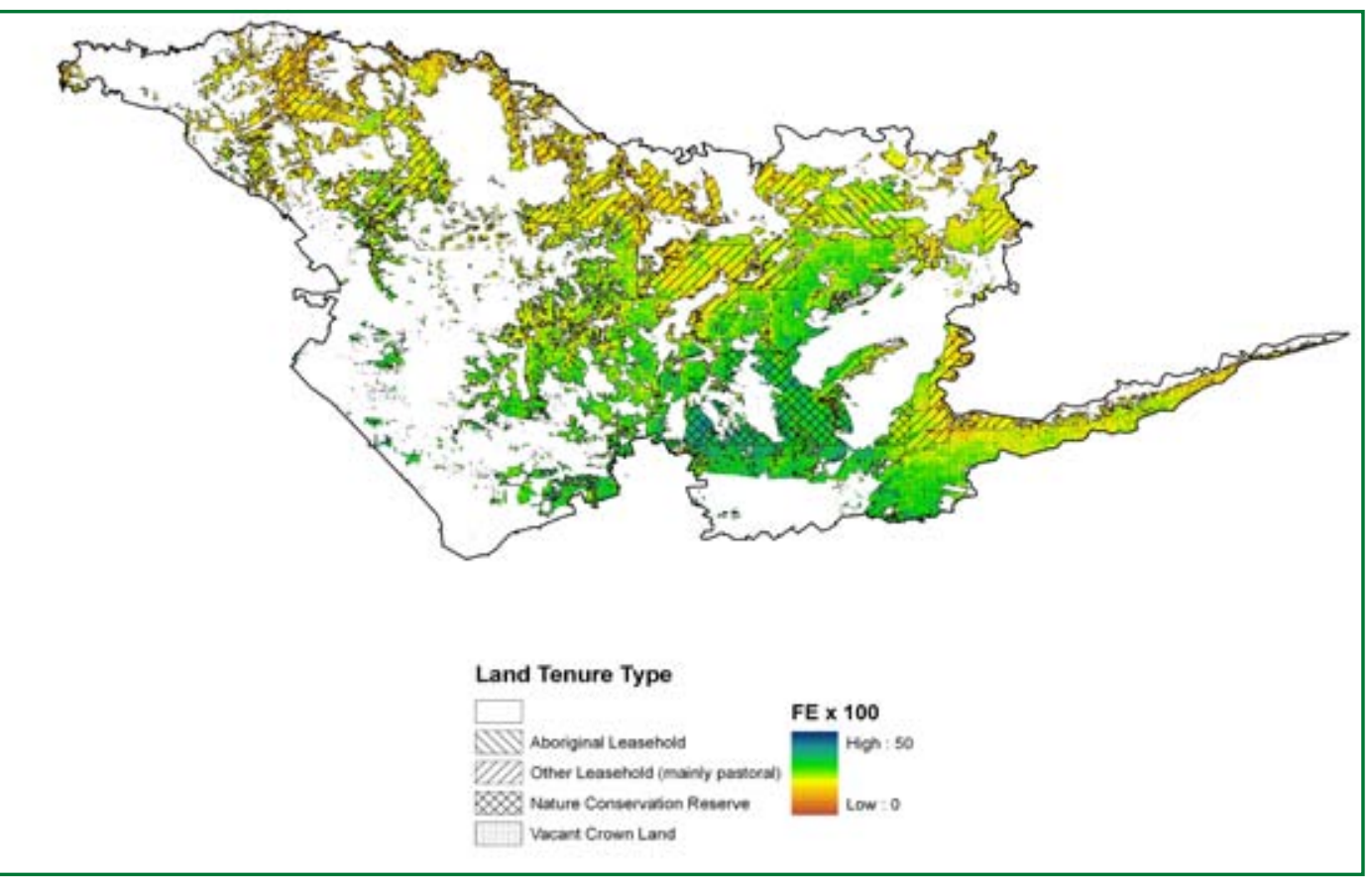

Figure $3.23 \mathrm{~F}_{\mathrm{E}}$ of extant eucalypt woodland in 2008 , overlayed with land tenure type (see Table $A 1$ - Land Tenure). Note the lower values of $F_{E}$ for woodland under leasehold land tenure.

This figure incorporates Australian land tenure (1993) data that are Copyright Commonwealth of Australia 1993.

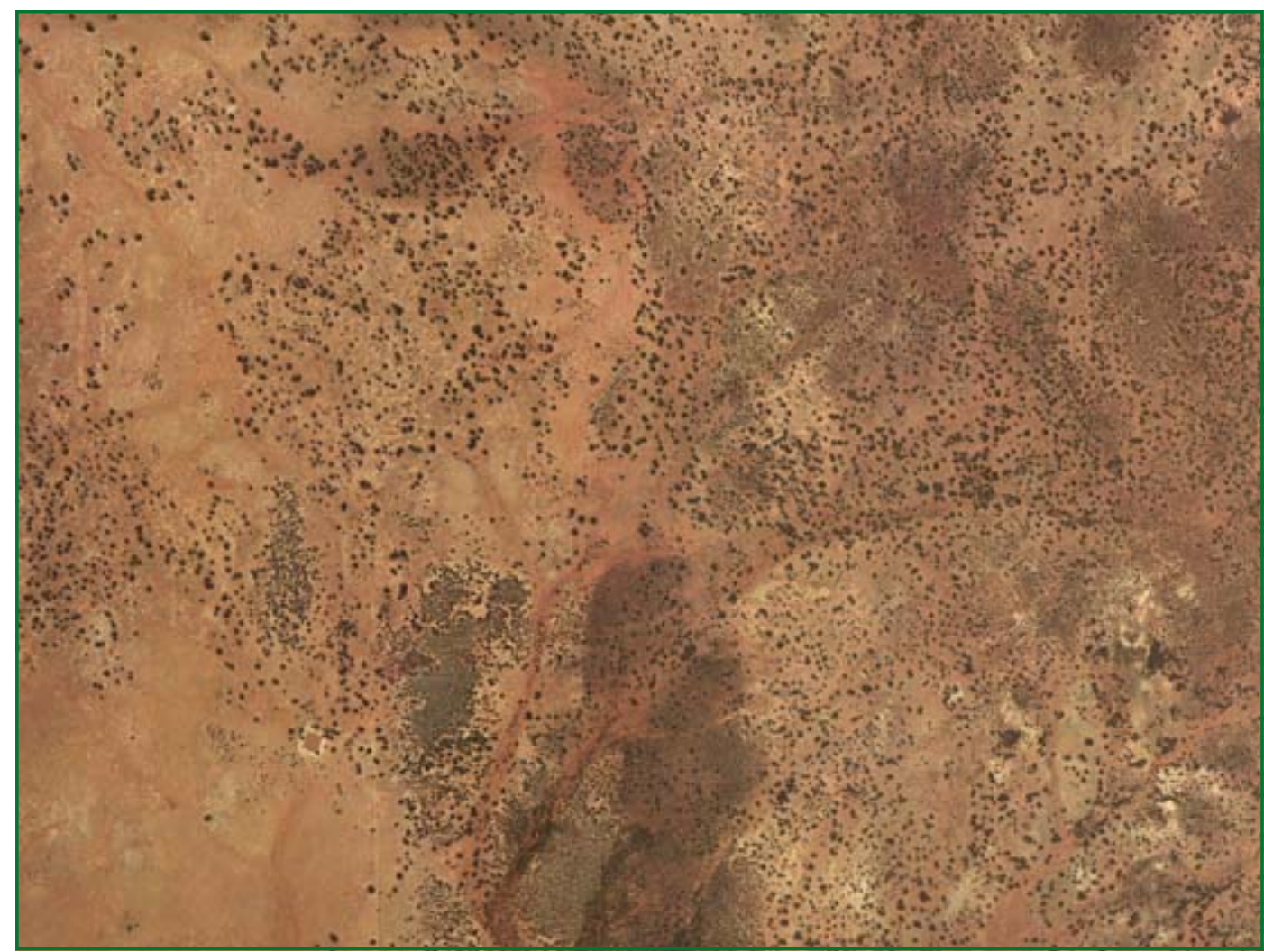

Plate 6 Aerial photograph showing a region mapped as woodland under leasehold land tenure in the GWW, north-east of Kalgoorlie. The region has low $F_{E}\left(F_{E}=0\right.$ in some MODIS pixels) and expanses of bare ground are clearly visible. A dam is visible in the south-western quarter.

Reproduced by permission of WA Land Information Authority, CL34/2010 (<www.landgate.wa.gov.au>). 


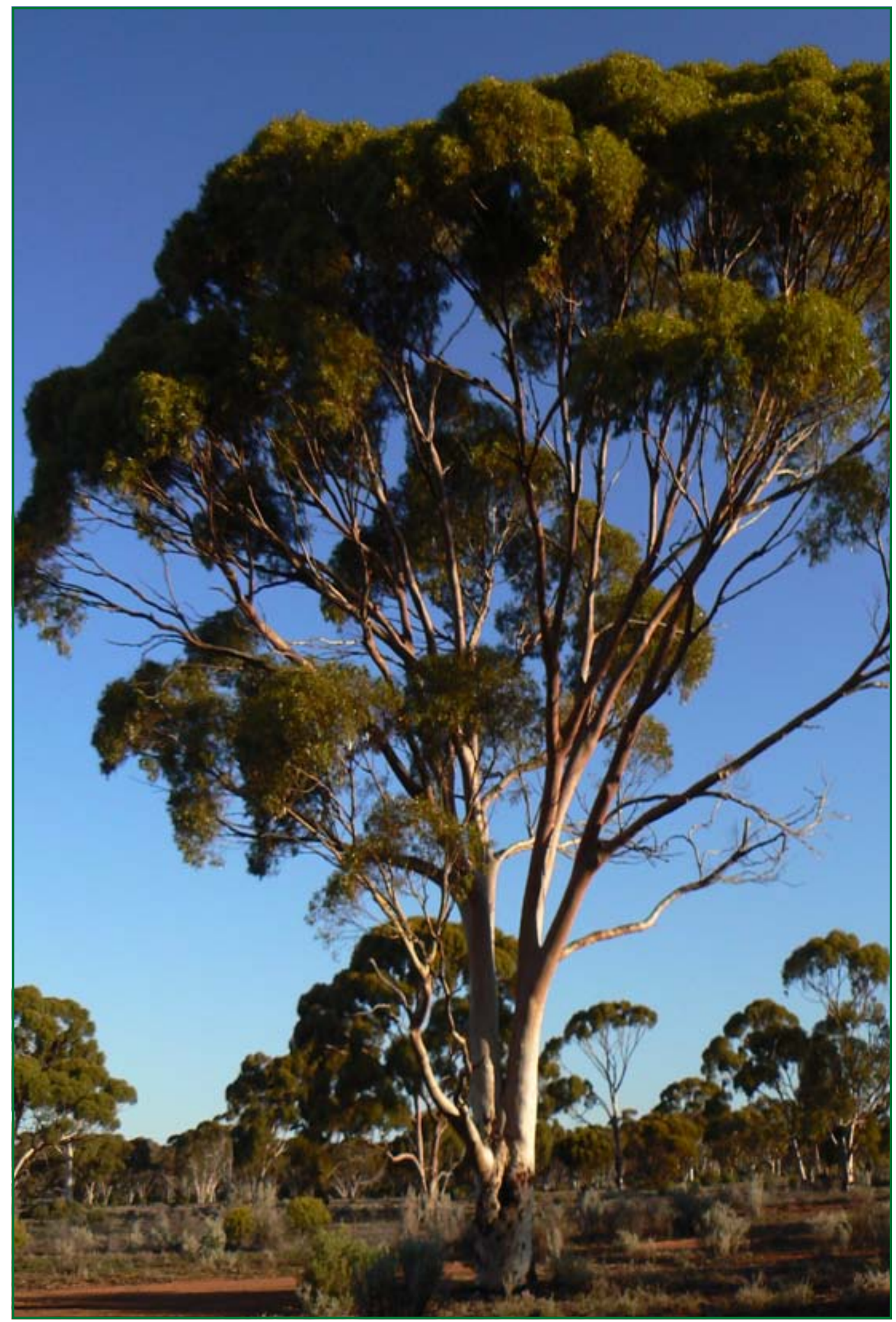

Plate 7 Salmon Gum (Eucalyptus salmonofloia) woodland on Jaurdi Station, a former pastoral lease now managed by WA Department of Environment and Conservation. 


\section{SPATIAL BIOMASS AND CARBON ESTIMATES FOR THE GWW, 2008}

Based on the methods and data detailed above, estimates of biomass and carbon content for the GWW are presented in Figure 4.1 and Table 4.1. We have assumed that carbon makes up 50 per cent of plant dry-mass or biomass (Gifford 2000). The four equations in the previous section were used for the categories of: undisturbed woodland (Figure 3.13); woodland disturbed by timber cutting (regardless of mineral exploration; Figure 3.15); woodland not disturbed by timber cutting but disturbed by mineral exploration (all uncut woodland on granite-greenstone lithology); and other woody vegetation of heath, shrub, marlock, mallee and low open woodland (Figure 3.13). In cases where both mineral exploration and timber cutting have occurred, the equation for timber cutting (Equation 3.10) was applied, as this represents the greater disturbance. $A G B$ was calculated from the $F_{E}$ value for every pixel within the area for each category. $B G B$ and $A G B_{\text {dead }}$ were then calculated from $A G B$. The sum of biomass carbon for the area of each category gave the total biomass carbon for the area mapped as the GWW to be 312 Mt. This value represents the current carbon stock inclusive of the impacts of human activities and natural disturbance regimes. Table 4.1 gives the estimated current biomass and biomass carbon stock for the GWW, while in Table 4.2 the values for the four vegetation categories are shown. A map showing the distribution of $A G B$ is presented in Figure 4.1. In this figure, we also provide histograms showing the frequency distribution of grid cells within size classes of AGB predicted by our models for the present (2008) vegetation and the 'no-disturbance scenario' (Chapter 5). We have not provided maps of the other biomass components as these have a linear relationship to AGB.

We compared the GWW total biomass carbon stock estimate with an estimate derived from the continental analysis of Berry and Roderick (2006) of 437 Mt. The latter estimate was derived using global empirical relationships between fluxes (net primary productivity and gross primary productivity) and carbon stocks in stems, roots and leaves. The GWW values were extracted from the spatial layer of continental carbon stocks. Berry and Roderick assumed that the GWW vegetation was in its climax successional state and did not account for the removal of biomass carbon through timber cutting. The inputs included a data set of $F_{E}$ calculated from the 1981-91 monthly time-series of $\mathrm{NDVI}$ at $\sim 5 \mathrm{~km} \times 5 \mathrm{~km}$ spatial resolution sourced from NOAA AVHRR ${ }^{10}$ satellite imagery. $F_{E}$ is an input variable into the Berry and Roderick model and our spatial estimates, but the $F_{E}$ spatial layers for the two models were derived from different satellite data sets-different satellite sensors and different time periods, 1981-91 for the Berry and Roderick model. We tested the possibility that differences in $F_{E}$ could be a major driver of differences in model outputs. We re-projected the $F_{E}$ spatial data layer of Berry and Roderick (2006) to match the projection and grid-cell size of our MODIS imagery, then created a difference image by subtracting the mean $F_{E}$ for the 12-month period (from July 2006 to June 2007) from the re-projected Berry and Roderick image. This difference image is shown in Figure 4.2. This revealed that over large areas of the GWW there is little difference in $F_{E}$ between the 1981-91 period and our 2006-07 imagery. In some parts of the GWW, however, $F_{E}$ clearly is lower at present than it was two decades ago. To assess the reasons for this change, we show the fire footprints and land tenure as overlays in Figure 4.2. Major reductions in $\mathrm{F}_{\mathrm{E}}$ appear to result from fire, but land clearing associated with livestock grazing and mining also appears to have reduced $F_{E}$ in the northern GWW where fire is absent.

10 National Oceanic and Atmospheric Administration Advanced Very High Resolution Radiometer. 


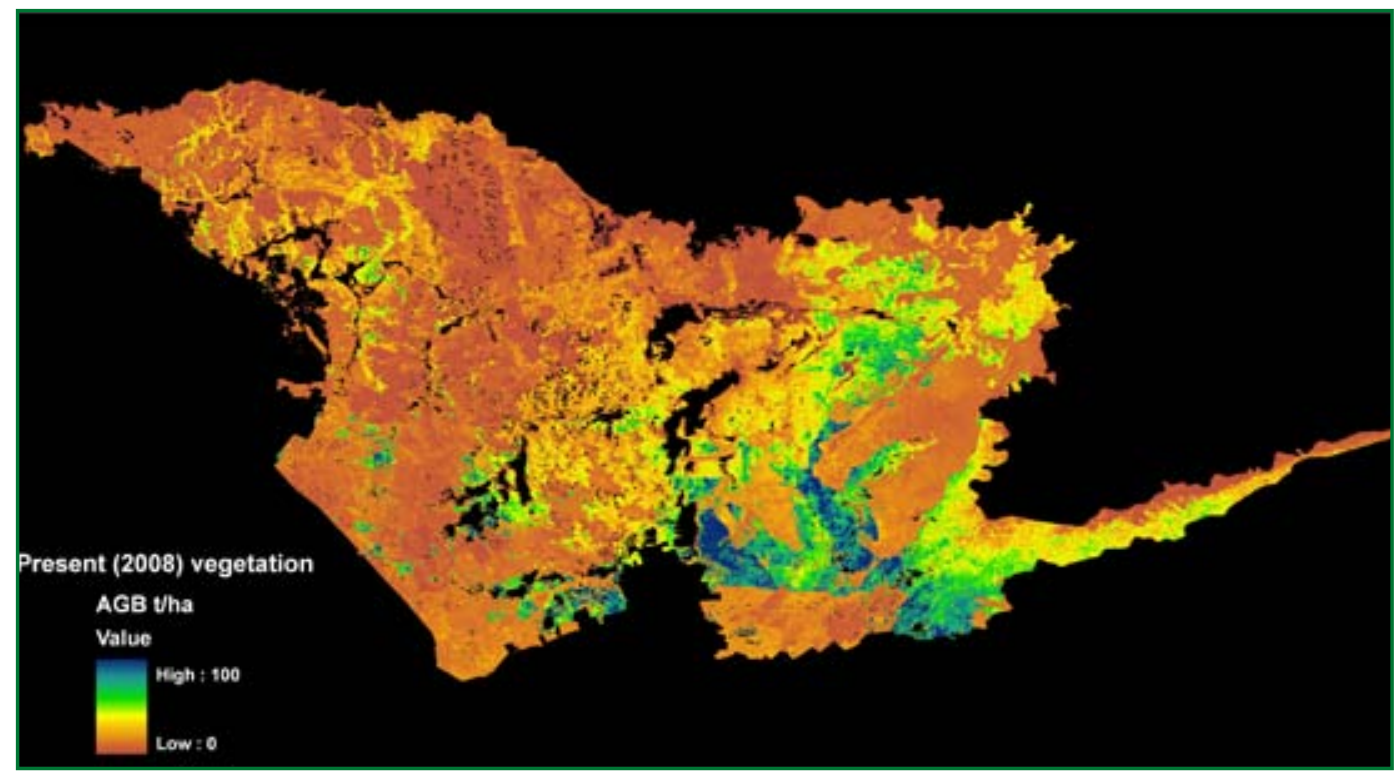

Figure 4.1a

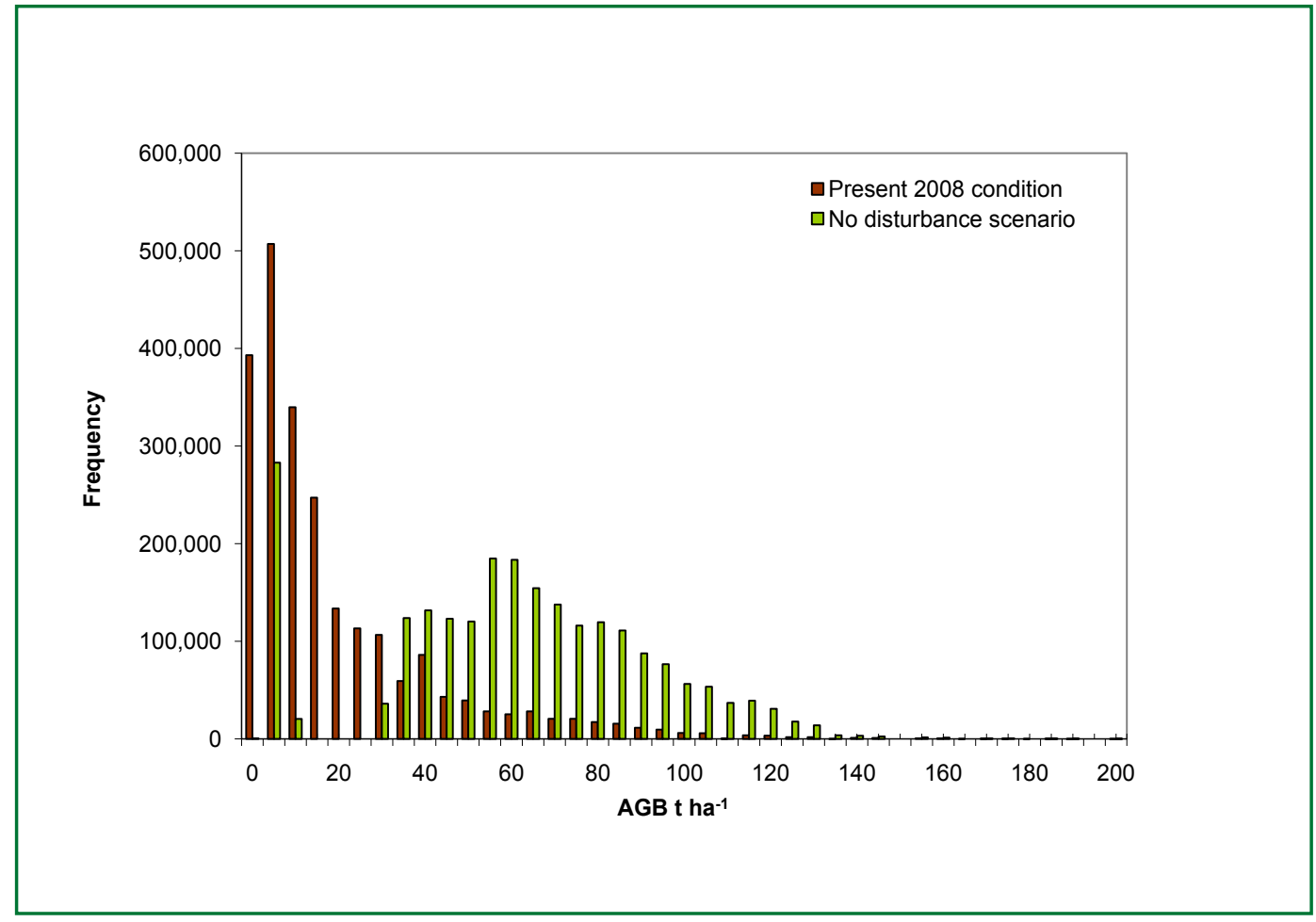

Figure $4.1 \mathrm{~b}$

Figures 4.1 (a) Map showing estimated above-ground biomass ( $A G B, t$ ha $^{-1}$ ) for the GWW based on vegetation structure shown in Figure 3.13. (b) Histogram showing the frequency distribution of $250 \mathrm{~m} \times 250 \mathrm{~m}$ grid cells within size classes of AGB for the present (2008) vegetation (see Figure 3.13) and the predicted AGB for the 'no-disturbance scenario' (see Figure 3.14). The AGB carbon is equivalent to 50 per cent of the $A G B$ and it has units of $t \mathrm{C} \mathrm{ha-1}$. 


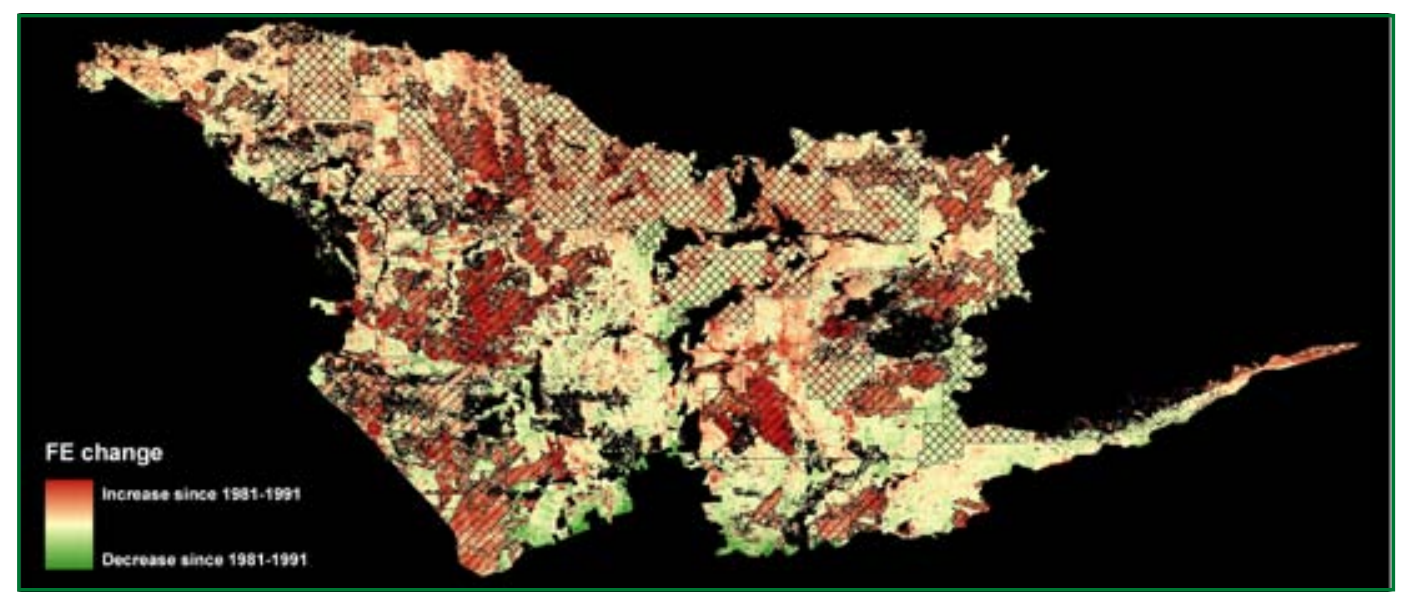

Figure 4.2 Difference image showing the change in FE between 1981-91 (Berry and Roderick 2006) and 2006-07. Red areas indicate a reduction in greenness since 1981-91 and green areas indicate an increase. Cream areas show no change. Single hatches indicate fire footprints mapped over the period 1991-2007. Cross-hatching identifies the location of land under leasehold and freehold land tenure types.

The estimated mean AGB carbon of long-undisturbed woodland (category [i] in Table 4.2 ) is $24+\mathrm{ha}^{-1}$ while the mean living biomass carbon (AGB + BGB) is $38+\mathrm{ha}^{-1}$. These values fall within the range of biomass carbon estimates reported for studies in other Australian woodlands (Table 4.3). We find, however, that the carbon density ( $\mathrm{C} \mathrm{Cha}^{-1}$ ) of living biomass in the long-undisturbed woodlands of the GWW is just 13 per cent of the estimated mean carbon density in living biomass of long-undisturbed forests of southeastern Australia (Table 4.3). This is to be expected, as the south-eastern forests occur where there is much greater water availability throughout the year (Specht 1981) and consequently there are more trees per hectare having larger stem diameters (dbh) and taller stems. All else being equal, we would predict from Equations 3.8 and 3.9 that AGB of woodland affected by mineral exploration (that is, on greenstone), but not affected by timber cutting (category [ii] in Table 4.2), would be $\sim 70$ per cent of the value for the long-undisturbed woodland (category [i]), and this is the case. Similarly, Equations 3.8 and 3.10 predict that the AGB of woodland affected by timber cutting (category [iii] in Table 4.2) should be $\sim 52$ per cent of the category (i) value. We find, however, that the category (iii) value is just 46 per cent of the category (i) value. A substantial area that has been subjected to timber cutting previously is now leasehold land tenure and, as we noted above, the woodland appears to have been partly cleared or thinned. Consequently, the carbon stock has been reduced more than would be expected from timber cutting alone.

For shrublands and non-eucalypt dominated woodlands (category [iv]) that now cover $\sim 54$ per cent of the GWW, the estimated mean AGB carbon is $4 \mathrm{tha}^{-1}$. This is comparable with estimates obtained for heath by several studies in southern Australia and for eucalypt re-growth in semi-arid Queensland (see Table 4.4). Our estimate of $3+C$ hall $^{-1}$ for $B G B$ is, however, much lower than published estimates of BGB of heath (Table 4.4). Thus, we could have underestimated the BGB of category (iv) vegetation, though this would need to be confirmed by field studies.

These results for the spatial estimation of biomass for the GWW are limited by the available data and information used as input to the models. The 21 field sites provided limited calibration data given the large variation in vegetation type and disturbance classes. It is also important to be clear on the assumptions used in our modelling. 
- We assumed that the trees in the GWW are similar in wood density, structure, degree of piping by termites, and so on, to the trees from which the applied allometric equation was derived.

- We identified two major types of disturbance in woodlands-timber cutting and mineral exploration-and we applied individual equations that related canopy greenness to $A G B$ (Equations 3.9 and 3.10) to account for the impact of each of these types of disturbance on the site AGB. We do not know precisely the extent to which the biomass was impacted, or has recovered, within the area mapped as being disturbed. We do not specifically model the impacts of pastoralism. Where woodland under leasehold land tenure has been disturbed by mineral exploration and/or timber cutting, we applied Equations 3.9 and 3.10. We assumed that any additional woodland thinning or clearing due to pastoralism was adequately accounted for in these equations through a reduction in canopy greenness $\left(F_{E}\right)$.

- We do not have reliable allometric equations for non-tree woody species. Rather, we used an estimated geometric function for which field validation is necessary. We note, however, that in studies of forest vegetation biomass carbon, the shrub component is commonly not estimated as it is very small in comparison with the tree biomass.

- Boundaries of the disturbance categories of timber cutting and mineral exploration were derived from available maps. The timber-cutting map shows the general area of cutting but no information about intensity or volumes of timber extracted. The mineral exploration impacts were based on the 1:250 000 scale surface lithology layer (see Figure 2.6). We assumed that all areas within the mapped granite-greenstone belt have been equally impacted by mineral exploration.

- We modified the NVIS MVG vegetation map layer to take into account the impacts of fire on AGB. Areas mapped as eucalypt woodland (MVG 5) on the NVIS extant vegetation map, which have since been burnt in intense fires, were reclassified as low closed forests and tall closed shrublands (MVG 15) on our map of the vegetation structure of the GWW in 2008. We have assumed that intense fire kills all large eucalypt trees in the GWW and that they are replaced with a dense thicket of regeneration arising from seeds or root suckers. This assumption is consistent with published accounts and our analyses but needs to be further validated by additional field investigations and analyses.

- $B G B$ and $A G B_{\text {dead }}$ are calculated as proportions of $A G B$. Thus, any errors in the estimation of $A G B$ will be carried through into estimates of these other biomass components. We have no site measurement data to validate estimates of these components. 
Table 4.1 Estimated biomass and biomass carbon for the GWW. The area of vegetation cover over which the calculations are based is 14926197 ha. Three sets of values are given: present (2008) condition is the 'best estimate' based on current knowledge; no-disturbance scenario is an estimate of 'what might have been' if the woodlands had not been impacted on by fire, timber cutting, mineral exploration and pastoral land management; the Berry and Roderick 'pveg' is derived from their estimates (Berry and Roderick 2006) of biomass carbon for the Australian continent based on NOAA AVHRR satellite data from 1981 to 1991 and global empirical equations.

\begin{tabular}{|c|c|c|c|c|c|}
\hline \multicolumn{2}{|c|}{ Present 2008 condition } & $\begin{array}{l}\text { Average } \\
\text { biomass } \\
\text { t ha-1 }\end{array}$ & $\begin{array}{l}\text { GWW total } \\
\text { Mt }\end{array}$ & $\begin{array}{l}\text { Average } \\
\text { biomass } \\
\text { carbon } \\
\text { tha }^{-1}\end{array}$ & $\begin{array}{l}\text { GWW total } \\
\text { carbon Mt }\end{array}$ \\
\hline$A G B$ & $\begin{array}{l}\text { From Equations } \\
3.8-3.11\end{array}$ & 21.4 & 320 & 10.7 & 160 \\
\hline$B G B$ & $A G B \times 0.6$ & 12.8 & 192 & 6.4 & 96 \\
\hline $\begin{array}{l}\text { Live } \\
\text { biomass }\end{array}$ & $A G B+B G B$ & 34.3 & 511 & 17.1 & 256 \\
\hline$A G B_{\text {dead }}$ & $A G B \times 0.35$ & 7.5 & 112 & 3.8 & 56 \\
\hline$A G B_{\text {total }}$ & $\mathrm{AGB}+\mathrm{AGB}$ dead & 28.9 & 432 & 14.5 & 216 \\
\hline $\begin{array}{l}\text { Total } \\
\text { biomass }\end{array}$ & AGBtotal + BGB & 41.8 & 624 & 20.9 & 312 \\
\hline
\end{tabular}

\begin{tabular}{|c|c|c|c|c|c|}
\hline \multicolumn{6}{|c|}{ Berry-Roderick pveg } \\
\hline$A G B$ & Live biomass $\times 0.625$ & 30.0 & 448 & 15.0 & 224 \\
\hline$B G B$ & Live biomass - AGB & 18.0 & 269 & 9.0 & 134 \\
\hline $\begin{array}{l}\text { Live } \\
\text { biomass }\end{array}$ & $\begin{array}{l}\text { From Berry and } \\
\text { Roderick }\end{array}$ & 48.0 & 716 & 24.0 & 358 \\
\hline$A G B_{\text {dead }}$ & $A G B \times 0.35$ & 10.5 & 157 & 5.3 & 79 \\
\hline$A G B_{\text {total }}$ & $A G B+A G B_{\text {dead }}$ & 40.5 & 605 & 20.3 & 303 \\
\hline $\begin{array}{l}\text { Total } \\
\text { biomass }\end{array}$ & AGBtotal + BGB & 58.5 & 874 & 29.3 & 437 \\
\hline
\end{tabular}

\begin{tabular}{|c|c|c|c|c|c|}
\hline$A G B$ & $\begin{array}{l}\text { From Equations } 3.8 \\
\text { and } 3.11 \text {; } F_{E} \text { from } W \\
\text { (Equations } 5.1 \& 5.2 \text { ) }\end{array}$ & 62.9 & 938 & 31.4 & 469 \\
\hline$B G B$ & $A G B \times 0.6$ & 37.7 & 563 & 18.9 & 281 \\
\hline $\begin{array}{l}\text { Live } \\
\text { biomass }\end{array}$ & $A G B+B G B$ & 100.6 & 1501 & 50.3 & 751 \\
\hline$A G B_{\text {dead }}$ & $A G B \times 0.35$ & 22.1 & 330 & 11.0 & 165 \\
\hline$A G B_{\text {total }}$ & $A G B+A G B_{\text {dead }}$ & 84.9 & 1268 & 42.5 & 634 \\
\hline $\begin{array}{l}\text { Total } \\
\text { biomass }\end{array}$ & $A G B$ total + BGB & 122.7 & 1831 & 61.3 & 915 \\
\hline
\end{tabular}


Table 4.2 Estimated biomass carbon in 2008 , for each of the modelled vegetation categories.

\section{Modelled class}

\begin{tabular}{|c|c|c|c|c|c|c|c|c|}
\hline \multicolumn{9}{|c|}{ Modelled class } \\
\hline & \multicolumn{2}{|c|}{$\begin{array}{l}\text { (i) No timber } \\
\text { cutting, } \\
\text { no mineral } \\
\text { exploration } \\
\text { disturbance }\end{array}$} & \multicolumn{2}{|c|}{$\begin{array}{l}\text { ((ii) Mineral } \\
\text { exploration, no } \\
\text { timber cutting }\end{array}$} & \multicolumn{2}{|c|}{$\begin{array}{l}\text { (iii) Timber } \\
\text { cutting }\end{array}$} & \multicolumn{2}{|c|}{$\begin{array}{l}\text { iv) Shrublands } \\
\text { and non- } \\
\text { eucalypt } \\
\text { dominated } \\
\text { woodlands }\end{array}$} \\
\hline Area $(\times 1000 \mathrm{ha})$ & \multicolumn{2}{|c|}{3327} & \multicolumn{2}{|c|}{2319} & \multicolumn{2}{|c|}{1269} & \multicolumn{2}{|c|}{8012} \\
\hline Carbon component & †C ha-1 & Mt C & †C ha-1 & Mt C & † C ha-1 & Mt C & †C ha-l & Mt C \\
\hline AGB mean [standard deviation] & $24[14]$ & 79 & $17[11]$ & 22 & $11[6]$ & 25 & $4[3]$ & 34 \\
\hline BGB mean & 14 & 47 & 10 & 13 & 6 & 15 & 3 & 20 \\
\hline Living biomass & 38 & 127 & 27 & 40 & 17 & 35 & 7 & 54 \\
\hline Total biomass (living + dead) & 46 & 155 & 33 & 48 & 20 & 42 & 8 & 54 \\
\hline Soil & 38 & 125 & 39 & 91 & 39 & 49 & 42 & 339 \\
\hline Total carbon stock & 84 & 280 & 72 & 139 & 60 & 91 & 51 & 406 \\
\hline
\end{tabular}

Table 4.3 Comparison of carbon stocks for the GWW and estimates published by other studies for Australia woodlands ${ }^{11}$.

\begin{tabular}{|c|c|c|c|c|}
\hline \multirow[t]{2}{*}{ Vegetation type and location } & \multirow[t]{2}{*}{ Author } & \multicolumn{3}{|c|}{$\begin{array}{l}\text { Carbon stock }\left(\dagger \mathrm{C} \mathrm{ha}^{-1}\right) \text { mean } \\
\text { [standard deviation] }\end{array}$} \\
\hline & & AGB & BGB & Living \\
\hline $\begin{array}{l}\text { Temperate eucalypt woodland, no timber } \\
\text { cutting, no mineral exploration disturbance GWW }\end{array}$ & This study & $24[14]$ & 14 & 38 \\
\hline Tropical savanna woodland & $\begin{array}{l}\text { Cook et al. (2005) } \\
\text { Kapalga, NT }\end{array}$ & & & $\begin{array}{l}22.9[7.8] \text { shallow } \\
\text { soil } 43.5[6.6] \\
\text { deep soil }\end{array}$ \\
\hline Tropical savanna woodland & Chen et al. (2003) & $30.7[7.3]$ & $19.3[12.6]$ & $50[19.9]$ \\
\hline Black box woodland, Victoria & Grierson et al. (1992) & 25.0 & & \\
\hline $\begin{array}{l}\text { Eucalyptus crebra intact woodland, central } \\
\text { Queensland }\end{array}$ & Burrows et al. (2000) & $56.7[13]$ & & \\
\hline $\begin{array}{l}\text { Eucalyptus melanophloia intact woodland, } \\
\text { central Queensland }\end{array}$ & Burrows et al. (2000) & $20.7[4.7]$ & & \\
\hline $\begin{array}{l}\text { Eucalyptus populnea intact woodland, } \\
\text { central Queensland }\end{array}$ & Burrows et al. (2000) & $35.2[4.9]$ & & \\
\hline $\begin{array}{l}\text { Eucalypt on hills, mature; semi-arid } \\
\text { Queensland (rainfall 460-780 } \mathrm{mm}^{-1} \mathrm{r}^{-1} \text { ). Mean } \\
\text { canopy cover } 32.4 \%\end{array}$ & Fensham et al. (2002) & 36.0 & & \\
\hline $\begin{array}{l}\text { Eucalypt on clay, mature; semi-arid } \\
\text { Queensland (rainfall 460-780 } \mathrm{mm} \mathrm{y}^{-1} \text { ). Mean } \\
\text { canopy cover } 16.9 \%\end{array}$ & Fensham et al. (2002) & 18.3 & & \\
\hline $\begin{array}{l}\text { Eucalypt on texture-contrast soils, mature; } \\
\text { semi-arid Queensland (rainfall } 460-780 \\
\mathrm{~mm} \mathrm{yr}^{-1} \text { ). Mean canopy cover } 24.9 \%\end{array}$ & Fensham et al. (2002) & 34 & & \\
\hline $\begin{array}{l}\text { Eucalypt on sand, mature; semi-arid } \\
\text { Queensland (rainfall 460-780 } \mathrm{mm} \mathrm{yr}^{-1} \text { ). Mean } \\
\text { canopy cover } 29.3 \%\end{array}$ & Fensham et al. (2002) & 29.7 & & \\
\hline $\begin{array}{l}\text { Eucalyptus populnea open woodland, } \\
\text { central-west NSW }\end{array}$ & Harrington (1979) & 27.3 & & \\
\hline $\begin{array}{l}\text { Carbon carrying capacity, south- } \\
\text { eastern Australia forests }\end{array}$ & Mackey et al. (2008) & & & 289 [226] \\
\hline
\end{tabular}

11 See Raison et al. (2003) for a summary of biomass estimates. 
Table 4.4 Comparison of carbon stocks for GWW shrubland vegetation and estimates published by other studies for Australian shrublands ${ }^{12}$.

\begin{tabular}{|c|c|c|c|c|}
\hline \multirow[t]{2}{*}{ Vegetation type } & \multirow[t]{2}{*}{ Author and location } & \multicolumn{3}{|c|}{$\begin{array}{l}\text { Carbon stock }\left(\dagger \mathrm{C} \mathrm{ha}^{-1}\right) \\
\text { mean [standard deviation }\end{array}$} \\
\hline & & AGB & BGB & Living \\
\hline Temperate shrubland, GWW & This study & $4[3]$ & 3 & 7 \\
\hline $\begin{array}{c}\text { Eucalypt on texture-contrast soils, re-growth } \\
<5 \mathrm{~m} \text { tall; semi-arid Queensland (rainfall } 460-780 \\
\mathrm{~mm} \text { yr }{ }^{-1} \text { ). Mean canopy cover } 5.8 \%\end{array}$ & Fensham et al. (2002) & 1.7 & & \\
\hline $\begin{array}{l}\text { Eucalypt on sand, re-growth } \\
<5 \mathrm{~m} \text { tall; semi-arid Queensland (rainfall 460-780 } \\
\mathrm{mm} \mathrm{yr}^{-1} \text { ). Mean canopy cover } 14 \%\end{array}$ & Fensham et al. (2002) & 2.1 & & \\
\hline $\begin{array}{c}\text { Acacia on clay, re-growth } \\
<5 \mathrm{~m} \text { tall; semi-arid Queensland (rainfall } 460-780 \\
\mathrm{~mm} \mathrm{yr}^{-1} \text { ). Mean canopy cover } 9.1 \%\end{array}$ & Fensham et al. (2002) & 2.2 & & \\
\hline Heath, south-eastern South Australia & Specht et al. (1958) & 13.2 & & \\
\hline $\begin{array}{l}\text { Heath, south-eastern South Australia, } 12 \text { years } \\
\text { post-fire }\end{array}$ & Specht (1966) & 4.6 & & \\
\hline Heath, south-western WA & Low and Lamont (1990) & 7.0 & 15.4 & 22.7 \\
\hline Heath, Frankston, Victoria & Jones (1968) & $\begin{array}{l}4.8 \\
5.1\end{array}$ & $\begin{array}{l}30 \\
37\end{array}$ & $\begin{array}{l}34.8 \\
42.1\end{array}$ \\
\hline Heath, Wilsons Promontory, Victoria & Groves (1965) & 3.9 & 21 & 24.9 \\
\hline Heath, Wilsons Promontory, Victoria & $\begin{array}{l}\text { Groves and Specht } \\
\text { (1965) }\end{array}$ & $\begin{array}{l}6.8 \\
9.0 \\
14.0\end{array}$ & $\begin{array}{l}6.6 \\
17.3\end{array}$ & $\begin{array}{l}13.4 \\
26.3\end{array}$ \\
\hline
\end{tabular}

12 See Raison et al. (2003) for a summary of biomass estimates. 


\section{$\infty$}

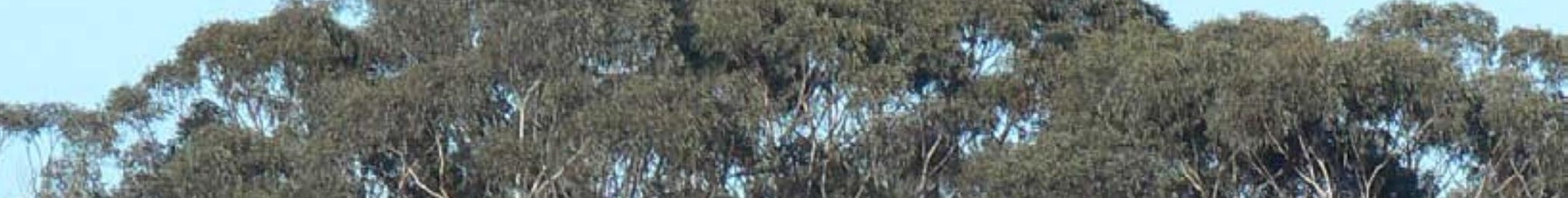
trescis (5) the 4. $\int(2)$

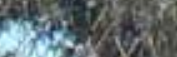

a.
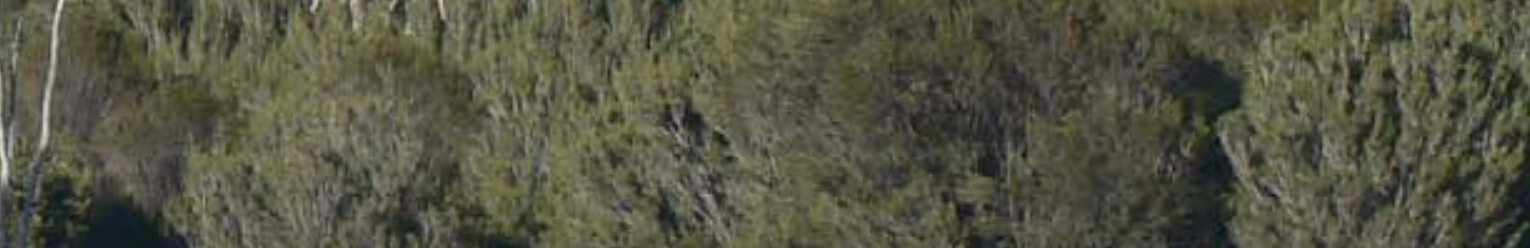

a.

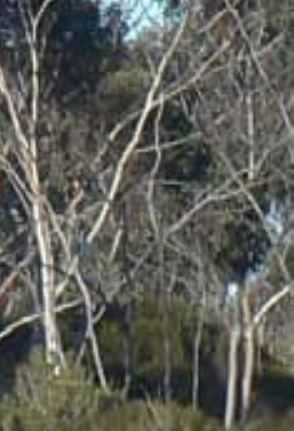

\section{(6)}

1.20. H.

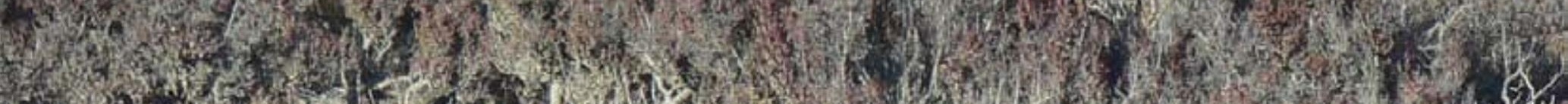

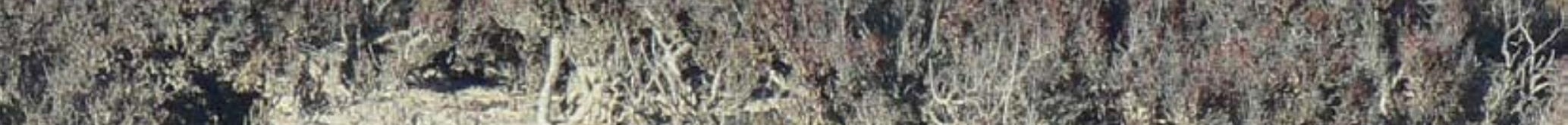

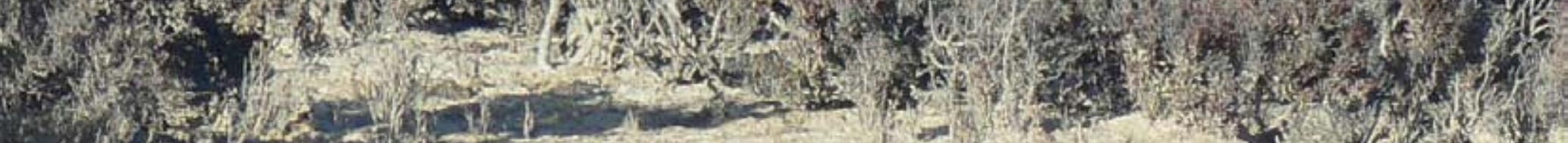

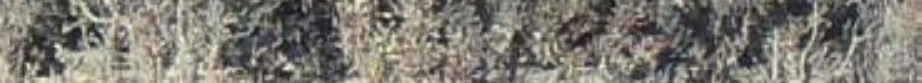

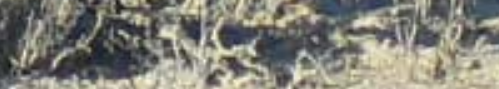

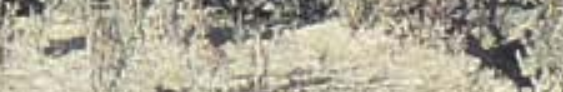




\section{BIOMASS AND CARBON ESTIMATES: HYPOTHETICAL NO-DISTURBANCE SCENARIO}

Our analyses reveal that the vegetation over significant areas of the GWW has been highly disturbed by direct and indirect human impacts (Figure 3.18) and consequently is below its carbon carrying capacity. The disturbance factors of changed fire regimes (primarily due to increases in human ignition), timber cutting and mining appear to have altered the vegetation structures such that the extant vegetation cannot be correlated with, and predicted from, environmental factors alone, as would be expected for natural ecosystems. As we noted in Sections 2.4 and 3.22, the published maps of pre-disturbance condition (AUSLIG 1990 and NVIS 3.0, DEWHA 2005) do not adequately take into account the disturbance to the vegetation of the GWW that occurred before the initial vegetation mapping. We determined that the best means of estimating vegetation structure, and hence its carbon carrying capacity, in the absence of disturbance by human activities was to assume a vegetation cover of woodland in all areas with potentially suitable environmental conditions, as is shown in Figure 3.14. To estimate the AGB for this scenario, we applied the equations derived for undisturbed vegetation (Equations 3.8 and 3.11).

Fire and land use have, however, clearly impacted on $F_{E}$ (see Figure 4.2). Thus, before applying these equations, we needed a better estimate of $F_{E}$ for undisturbed vegetation. In a study of the relationship between $F_{\text {PAR }}$ and climate over the Australian continent, Berry and Roderick (2002) found that there was a linear relationship between $F_{P A R}$ and W-an index of water availability - along the aridity gradient (Equation 5.1).

\section{Equation 5.1}

$W=P-R_{S} / L$

In Equation 5.1, $\mathrm{P}\left(\mathrm{mm} \mathrm{yr}^{-1}\right)$ is the average precipitation, $\mathrm{R}_{\mathrm{s}}$ is the sum of the global solar irradiance over the annual period $\left(\mathrm{MJ} \mathrm{m}^{-2} \mathrm{yr}^{-1}\right)$ and $\mathrm{L}$ is the amount of energy (joules) required to evaporate $1 \mathrm{~kg}$ of liquid water. (Note that $1 \mathrm{~kg}$ of water is equivalent to a $1 \mathrm{~mm}$ thick layer of water over a square metre of surface.) A map showing the distribution of W over the GWW is given in Figure 5.1. As W has negative values, we added a constant-3000-to create the variable $W_{3000}$ for subsequent analyses.

In order to relate $W_{3000}$ to $F_{E,}$ we first identified those grid cells within the GIS layer of $F_{E}$ that represent long-undisturbed woodland vegetation $\left(F_{E l u v}\right)$. We then plotted $F_{\text {Eluv }}$ against $W_{3000}$ and derived the equation of best fit (Equation 5.2).

\section{Equation 5.2}

$F_{\text {Eluv }}=0.03 \mathrm{~W}_{3000}+18$

Following that, we created a spatial layer that comprised the maximum value of $F_{\text {Eluv }}$ predicted from Equation 5.2 and actual $F_{\text {Eluv }}$ (Figure 5.2). Finally, we calculated AGB for undisturbed vegetation using Equations 3.8 and 3.11. A summary of the biomass estimates for the GWW under the no human disturbance scenario is included in Table 4.1 and a histogram showing the frequency distribution of size classes of $A G B$ 'no-disturbance scenario' is shown in Figure 4.1. Biomass carbon for this scenario was $915 \mathrm{Mt}$ for the GWW-approximately three times the estimated present biomass. In Figure 4.1, the low values of $A G B$ (that is, less than $15 \mathrm{tha}^{-1}$ ) are associated with noneucalypt dominated vegetation groups (MVGs 6, 7, 8, 17, 18, 20, 22). We have no 
field measurements of biomass of undisturbed MVGs 6, 7 and 8 to test the veracity of these estimates. We speculate, however, that our modelled estimates understate the AGB of undisturbed Acacia (mulga, MVG 6), Callitris (MVG 7) and Casuarina (MVG 8) woodlands in the GWW.

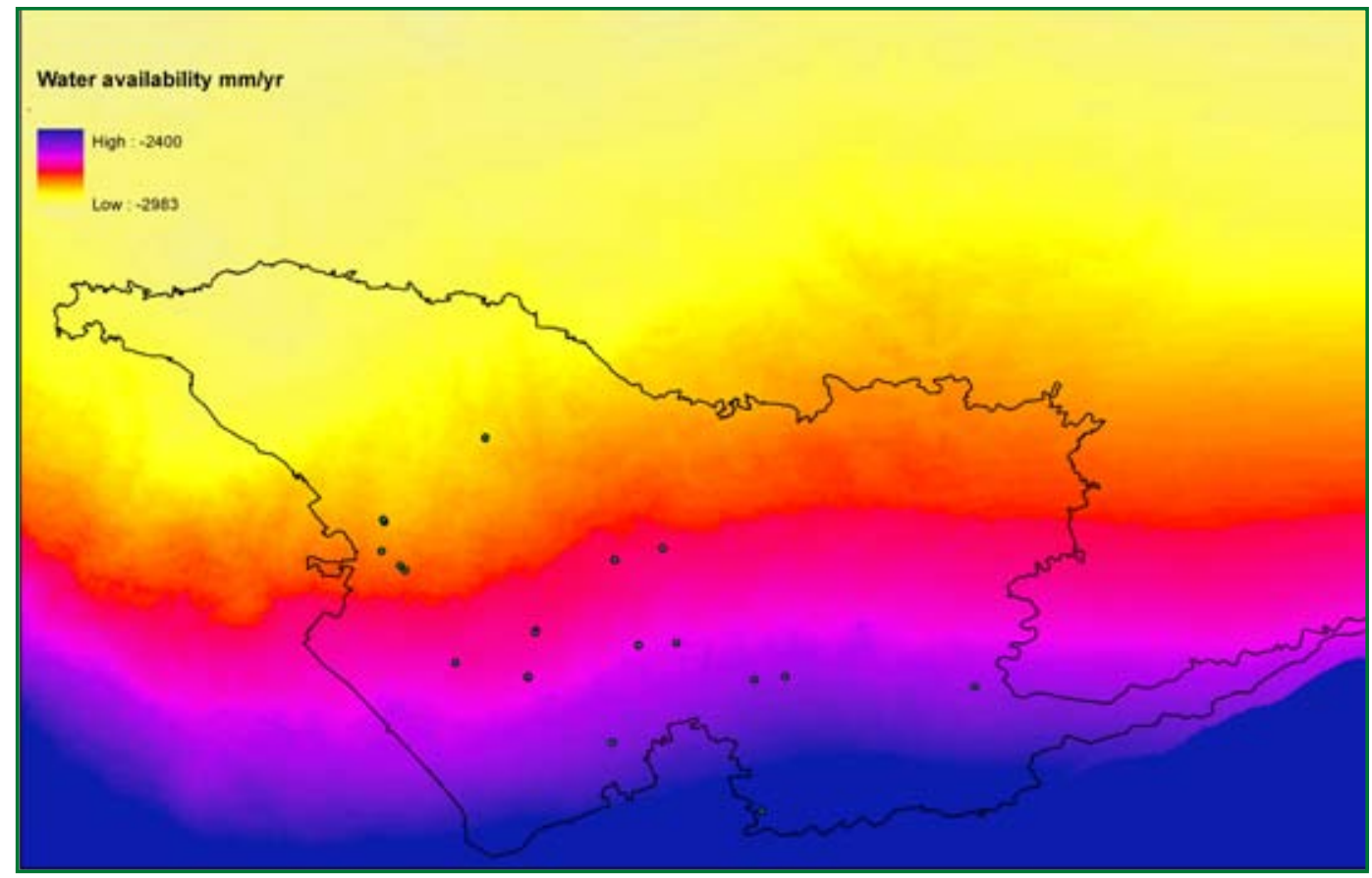

Figure 5.1 Map showing spatial variability of a climatic index of water availability (W) over the GWW. The locations of the ANU field sites are indicated by the green circles.

For source of spatial data inputs for calculation of $W$, see Table Al- $R_{S}$ and $P$.

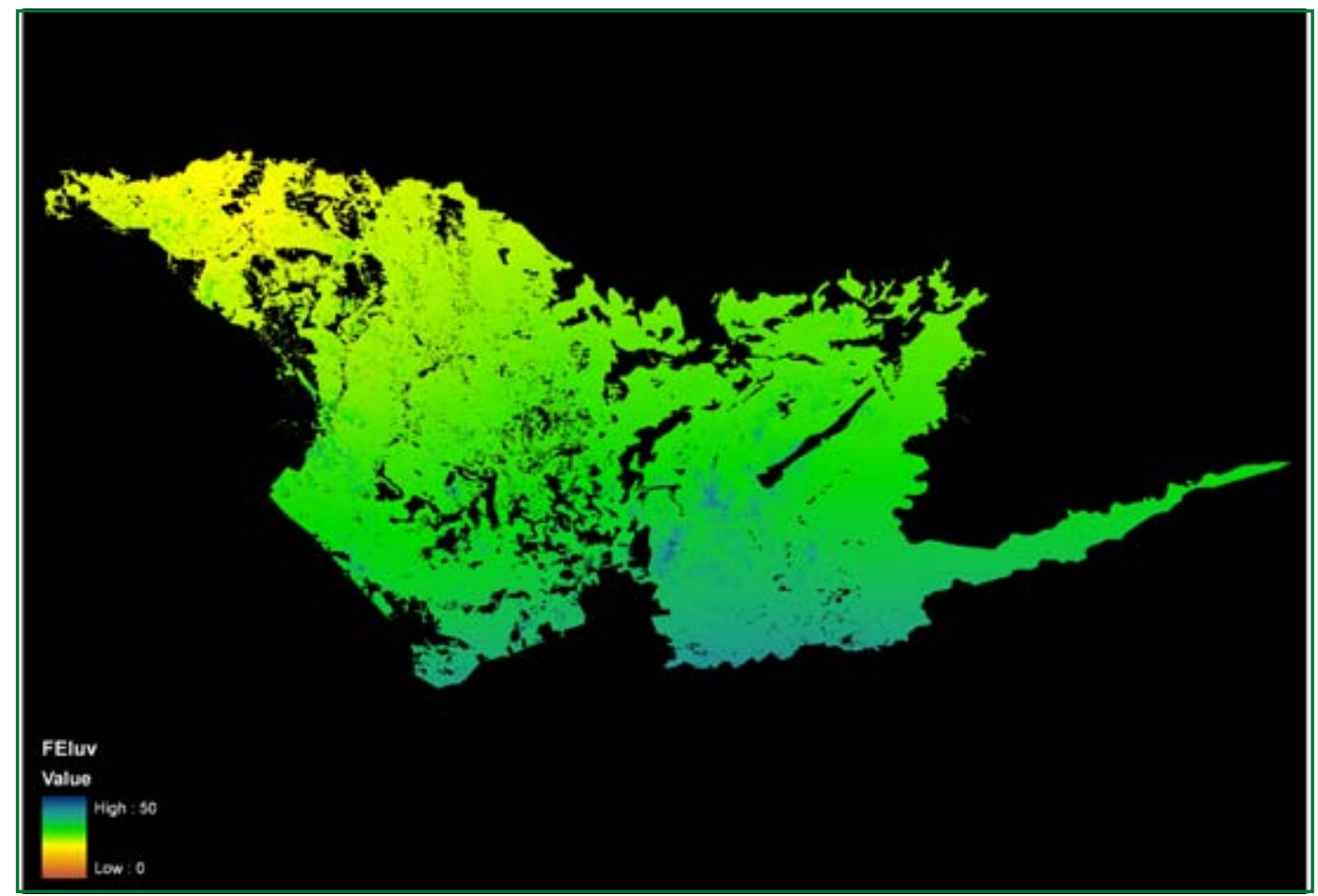

Figure 5.2 Map showing estimated $\mathrm{F}_{\text {Eluv' }} \mathrm{F}_{\mathrm{E}}$ of vegetation if it were in the long-undisturbed condition, estimated from the water availability index, W (see Equation 5.1). 


\section{SOIL CARBON}

Soil is widely recognised as containing the largest pool of terrestrial carbon (Jobbágy and Jackson 2000) and components of the soil organic carbon pool (SOC) have great longevity-up to centuries or millennia. There are, however, very few studies of SOC in forest and woodland ecosystems in Australia. A study by Skjemstad et al. (1996), which covered a range of soil types, revealed that charcoal made up to 30 per cent of the SOC in the Australian soils they sampled. Other constituents having great longevity included humic acids and lignins.

There were no data for SOC for the GWW, so we needed to use a modelling approach to provide an estimate and complete the carbon budget. We identified two publicly available spatial data sets: the Australian Soil Resource Information System (ASRIS) (CSIRO 2007) and SOC data from the field study by Wynn et al. (2006).

The ASRIS spatial data set provides only partial coverage of SOC in the GWW, but it does have full coverage of estimated soil thickness and bulk density of the $A$ and $B$ horizons. Where coverage exists, SOC of the A and B soil horizons was calculated (Figure 6.1).

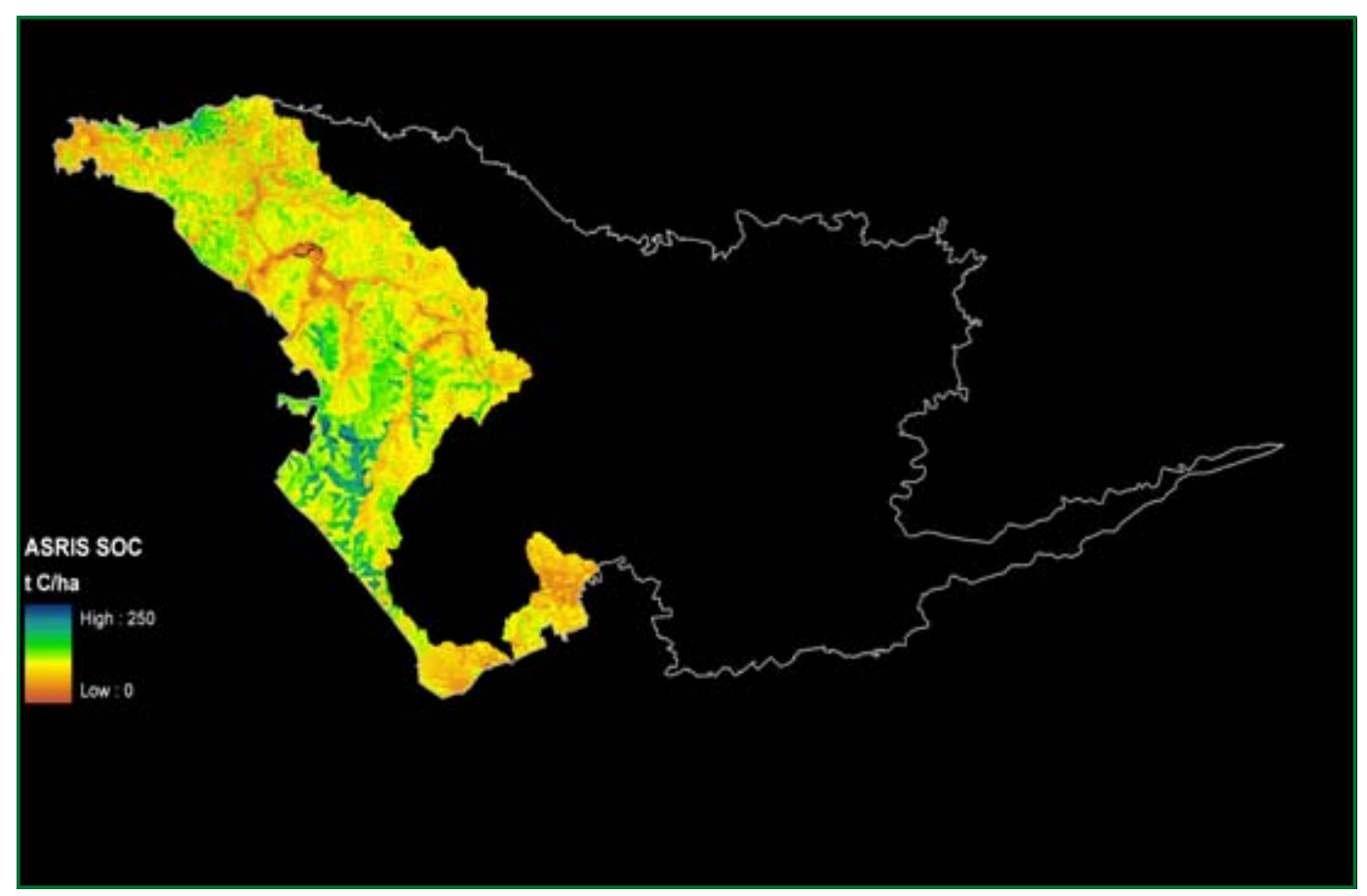

Figure 6.1 Total soil organic carbon derived from ASRIS (CSIRO 2007) spatial data layers.

Data source: SOC-Table A1.

The field survey of Wynn et al. extended over a wide range of environments within 48 regions of Australia, but not in the GWW. They used 7050 soil cores to determine SOC for the top $30 \mathrm{~cm}$ of soils beneath trees and grasses for the 48 regions. They described the relationship between SOC (sandy soils) and the water availability index, W (see Equation 5.1), as a sigmoidal function. A supplementary table to Wynn et al. (2006) includes organic carbon fraction (fracC) values for the 48 regions. Using an average of the values of fracC in the top $30 \mathrm{~cm}$ obtained from sites with trees and grass, and excluding rainforest, pasture and graminoid (buttongrass-dominated) vegetation types, we derived the power relationship (Equation 6.1). 


\section{Equation 6.1}

fracC $_{\text {Wynn }}=0.00000002 \mathrm{~W}_{4000}{ }^{1.736} ; \mathrm{R}^{2}=0.73, \mathrm{n}=39$

in which

$W_{4000}=W+4000 \mathrm{~mm} \mathrm{yr}^{-1}$

The index of water availability, W, is defined in Equation 5.1. (Note: in Section 5, we calculated $W_{3000}$ as the addition of 3000 was sufficient to create a variable with positive values for the GWW. As Wynn et al. use $W_{4000}$ for their continental data set, we use this value to apply to analyses with their data.) We applied Equation 6.1 to our spatial data layer of $\mathrm{W}_{4000}$ to obtain spatial estimates of frac $\mathrm{C}$ in the $\mathrm{A}$ horizon. We compared these spatial estimates (frac $C_{\text {Wynn_A }}$ ) with the values in the ASRIS data layer (fracC $C_{\text {ASRIS }}$ ) using a linear regression analysis. The line of best fit was described by Equation 6.2.

\section{Equation 6.2}

$\operatorname{fracC}_{\text {Wynn_A }}=0.000023+0.366243$ fracC $_{\text {ASRIS_A }} ; R^{2}=0.90$

Although the spatial layers are correlated, the estimates based on the data of Wynn et al. are on average 37 per cent of the values given in the ASRIS database. The derivation of the ASRIS estimate and its source data are not known, thus we cannot conclude whether the ASRIS or the Wynn approach is preferable, except that ASRIS does not give coverage of SOC for the whole GWW.

We used the spatial estimates of frac $C_{W_{y n n} A}$ along with the ASRIS horizon thickness and bulk density to estimate SOC of the A horizon. Because the organic carbon is derived mostly from near-surface and above-ground plant parts, the fraction of organic carbon in the A horizon is greater than that in the B horizon. Consequently, we needed to adjust frac $C_{\text {Wynn_A, }}$ in order to estimate SOC in the B horizon. We find that for the area covered by ASRIS, the mean ratio of fracC $C_{\text {ASRIS_A }}$ : fracC $C_{\text {ASRISB }}$ is 2.13 . Applying this ratio, we have Equation 6.3.

\section{Equation 6.3}

fracC $_{W_{\text {Wnn_B }}}=\frac{\text { fracC }_{W_{\text {Whn_A }}}}{2.13}$

We used this spatial estimate of the fraction of $S O C$ in the $B$ horizon along with the ASRIS spatial estimates of the B horizon thickness and bulk density to calculate SOC for this soil layer. The estimates of $\mathrm{SOC}$ in the A and B horizons are presented in Figure 6.2 and Table 6.1.

The resulting estimated SOC-637 Mt C for the $\mathrm{GWW}$ or $40+\mathrm{C} \mathrm{ha}^{-1}$-was constant across all four vegetation categories (Table 4.2). This is approximately twice as much carbon as we estimated to make up the total biomass in 2008 (see Table 4.1). We noted above that the carbon content estimated from the measurement data of Wynn et al. (2006) is about 37 per cent of the estimate based on the ASRIS layers. Thus, we might expect that, if ASRIS coverage for the entire GWW was available, it would result in an estimate of $1722 \mathrm{MtC}$. This is almost twice as much carbon as we estimated to make up the total biomass in the hypothetical 'no-disturbance' scenario. 


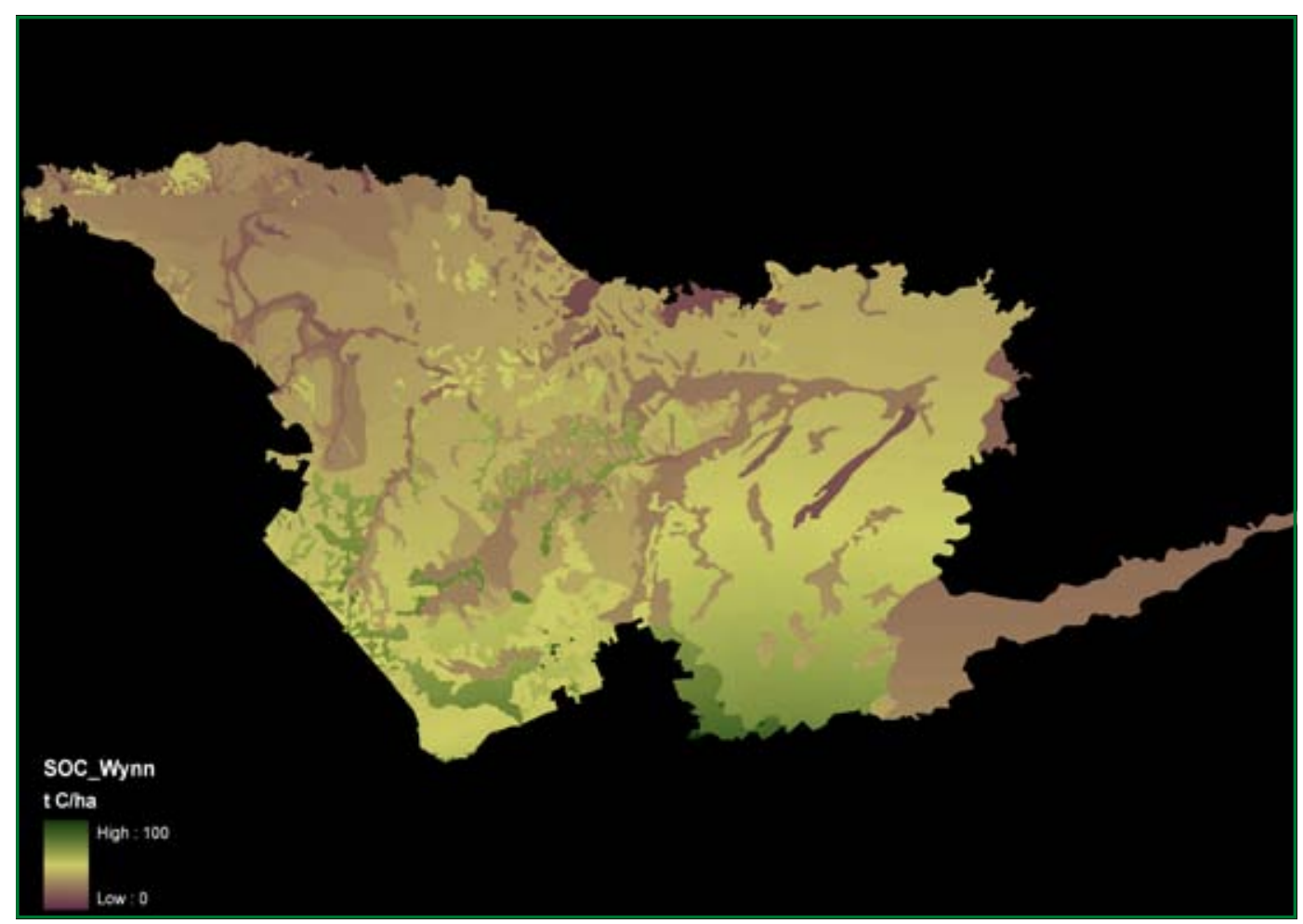

Figure 6.2 Map showing the estimated distribution of soil organic carbon (SOC, $\mathrm{C}^{\mathrm{ha}} \mathrm{ha}^{-1}$ ). Calculations were based on the relationship between the fraction of organic carbon in the soil and the water availability index, $\mathrm{W}$, using the data provided as supplementary material to Wynn et al. (2006). The depths and bulk densities of the uppermost soil horizons (A and B) are from ASRIS (CSIRO 2007) spatial data layers.

Data sources: Table Al.

Harms et al. (2005) found that soil carbon stocks at uncleared sites in the semi-arid rangelands of central and southern Queensland averaged 41 per cent of the mean total C (soil C plus biomass $C$ ). This corresponded to an average soil carbon stock for the top metre of soil of $62.5+\mathrm{C} \mathrm{ha}^{-1}$. In contrast, the $\mathrm{SOC}_{\mathrm{Wynn}}$ estimate averages $67 \mathrm{per}$ cent of the mean total $C$ stock in the GWW. As the live biomass in the GWW has been greatly reduced over recent decades due to tree kill by fire, a greater proportion of sOC to total $\mathrm{C}$ might be expected.

Table 6.1 Estimates of mass of soil organic carbon in the GWW. The estimated ASRIS A+B horizons value is based on the relationship given in Equation 6.2, which shows that, for the part of the GWW covered by ASRIS, our estimate based on the data of Wynn et al. is 37 per cent of the ASRIS value.

\begin{tabular}{l|c|c} 
Method-soil horizon & 20.4 & 325 \\
\hline Wynn A -horizon & 19.7 & 314 \\
\hline Wynn B -horizon & 40.1 & 639 \\
\hline Wynn A+B horizons & 108.0 & 1725 \\
\hline $\begin{array}{l}\text { ASRIS A+B horizons } \\
=\text { (Wynn A+B horizons) } \times 2.7\end{array}$ & & \\
\hline
\end{tabular}




\section{MANAGEMENT OPTIONS TO PROTECT AND RESTORE THE GWW'S CARBON STOCKS}

In this report, we define eucalypt woodlands as vegetation dominated by eucalypt trees exceeding $10 \mathrm{~m}$ in height and with a projective foliage cover ${ }^{13}$ of 10-30 per cent. The definition of eucalypt forests differs from woodlands only in that the projective foliage cover is $>30$ per cent (Table 2.1). At the time the GWW was first explored by European people, in expeditions led by Roe in 1849 and Lefroy in 1863 (Beard 1968), the region probably supported a far more extensive cover of eucalypt woodland and forest than it does now. If these woodlands were in an undisturbed condition, and had remained so to the present day, it is possible that the woodland structural formation would have a distribution similar to that depicted in Figure 3.14, with the woodland extending over 12.9 million ha, or 80 per cent of the GWW, with biomass carbon of $\sim 900 \mathrm{Mt}$. This 'nodisturbance scenario' model-derived estimate is based on an assumption that none of the woodland is in a pyric successional state (that is, recovering from fire), and it should be treated as an estimate of the maximum possible store of biomass carbon in the GWW if intense fire had been excluded for centuries. The distribution of woodland in Figure 3.14 is similar to, but more extensive than, that mapped in the Natural Vegetation Map (Figure 2.9a) and the NVIS map (Figure 2.10) because our analyses indicate that these map layers show pyric successional vegetation structural formations arising from fires that have occurred in the period following the advent of explorers, prospectors and timber cutters in the GWW.

We estimate, however, that at present (2008) eucalypt woodland extends over just 6.9 million ha, or 43 per cent, of the GWW, and the total biomass carbon of the GWW is -300 Mt. The 6 million ha that might once have had a vegetation cover of eucalypt woodland currently support a cover of eucalypt or acacia-dominated shrubland (NVIS MVGs 13-16). We attribute the change in vegetation structure primarily to changes in fire regimes: the advent and continuance of intense and more frequent fires in this region following the discovery of gold and subsequent settlement by European people. Timber cutting and the removal of vegetation for roads, seismic lines and excavations have also impacted on the biomass carbon stock. Our analyses, presented in Figure 3.8, indicated that during the period 1972-2007, 3.5 million ha of the GWW have been burnt by intense fire once, while 852000 ha have been burnt twice and 23000 ha have been burnt three times. In total, 4.4 million ha representing 30 per cent of the GWW have been burnt by intense fire over the past 36 years and now support pyric successional vegetation structural formations.

If fire were to be suppressed over the coming decades to centuries so that self-thinning could occur, the shrublands of seedling and re-sprouting eucalypts could re-grow into eucalypt woodland (MVG 5) with the proviso that the availability of water, nutrients and propagules post-fire is sufficient. From a management perspective, it can be argued that fire suppression will lead to fuel accumulation and subsequently to 'monster' fires (Bond and Keeley 2005). Thus, fire can be seen as a consumer of biomass that would otherwise accumulate indefinitely. This, however, disregards the role of wood-eating termites-voracious consumers of deadwood in the GWW. Several species of debris and wood-eating termites occur in the GWW (Hadlington 1987).

13 Projective foliage cover (PFC) is the proportion of the ground that would be shaded by the canopy on a clear day if the sun were directly overhead. Canopy cover is the proportion of the ground that lies beneath the crowns of the plants. PFC accounts for the gaps between the leaves in the canopy. 
That termites prevent the excessive accumulation of biomass in the GWW is evident from the photos of sclerophyll woodland in Figure 2.8. In the following sections, we discuss the causes of fire in the GWW, the options for fire management and, finally, the likely time required for the post-fire succession to return to woodland.

\subsection{FIRE IN THE GWW}

Our results suggest that fire plays a major role in the diminution of biomass carbon in the GWW and any attempt to maximise biomass carbon stocks in the GWW necessarily requires a substantial reduction in fire frequency and intensity. Therefore, we need to consider the causes of the intense and extensive wildfires that now ravage the GWW.

Wildfire has three basic requisites: a supply of fuel, a source of ignition and an agent of spread. Landscape topography is also an important factor at many locations as slope angle affects the rate of spread and landform complexity can add to fire patchiness. As the GWW has relatively little topographic relief, we do not consider this factor any further.

Fuel, or combustible matter, is a spatially and temporally variable entity. Vegetation structure accounts for the spatial arrangement of fuel within a volume above the ground surface. The eucalypt woodlands of the GWW mostly have a sparse understorey and the trees are widely spaced (foliage projective cover of woodland is 10-30 per cent). For this reason, Beard (1968:252) noted that woodland 'is subject to burning to only a minor extent'. Yet, we have shown from Landsat and MODIS satellite data that 4.4 million ha of woodland in the GWW have been burnt in intense fires over the past 36 years, and suggest that a further 2 million ha could have been burnt earlier given the occurrence of pyric successional vegetation structures. In the seven years (2000-07) for which we have MODIS NDVI imagery (see Table Al-MODIS), intense fires burnt more than 2.6 million ha of the GWW. Therefore, we argue that extensive areas of eucalypt woodland (Table 2.1, class M2) have been replaced by eucalypt or acacia-dominated shrublands (Figure 3.9; Table 2.1, class S3)-vegetation structures that, according to Beard (1968), are subject to more frequent fire.

Temporal variation in fuel depends on the moisture and heat content of the living and dead biomass, and hence its potential to become fuel at a given time. Moisture and heat content of biomass are dependent largely on the ambient air temperature, relative humidity and rainfall (see Figure 7.1). Lower moisture content and higher temperature of the biomass reduce the amount of energy required to reach the ignition point. Across the GWW there is a marked seasonal cycle with the seasonality of rainfall greater on the western edge of the GWW (near Southern Cross and Hyden), a distinct winter maximum at these locations and less seasonality of rainfall elsewhere in the GWW. The combination of high daily temperatures and low rainfall during summer across the GWW results in low biomass moisture content and high biomass heat content and subsequently high availability of fuel.

The two basic sources of ignition of wildfires are natural and human. Lightning strikes undoubtedly ignite some fires within the GWW; however, over most of the GWW the number of thunder-days recorded in a year averages less than 20-in contrast with the Northern Territory tropical savanna woodlands, which commonly experience 60 or more thunder-days (Figure 7.2). In a continental-wide study of causes of vegetation fires in Australia, Bryant (2008) found that only 6 per cent resulted from natural ignition. 


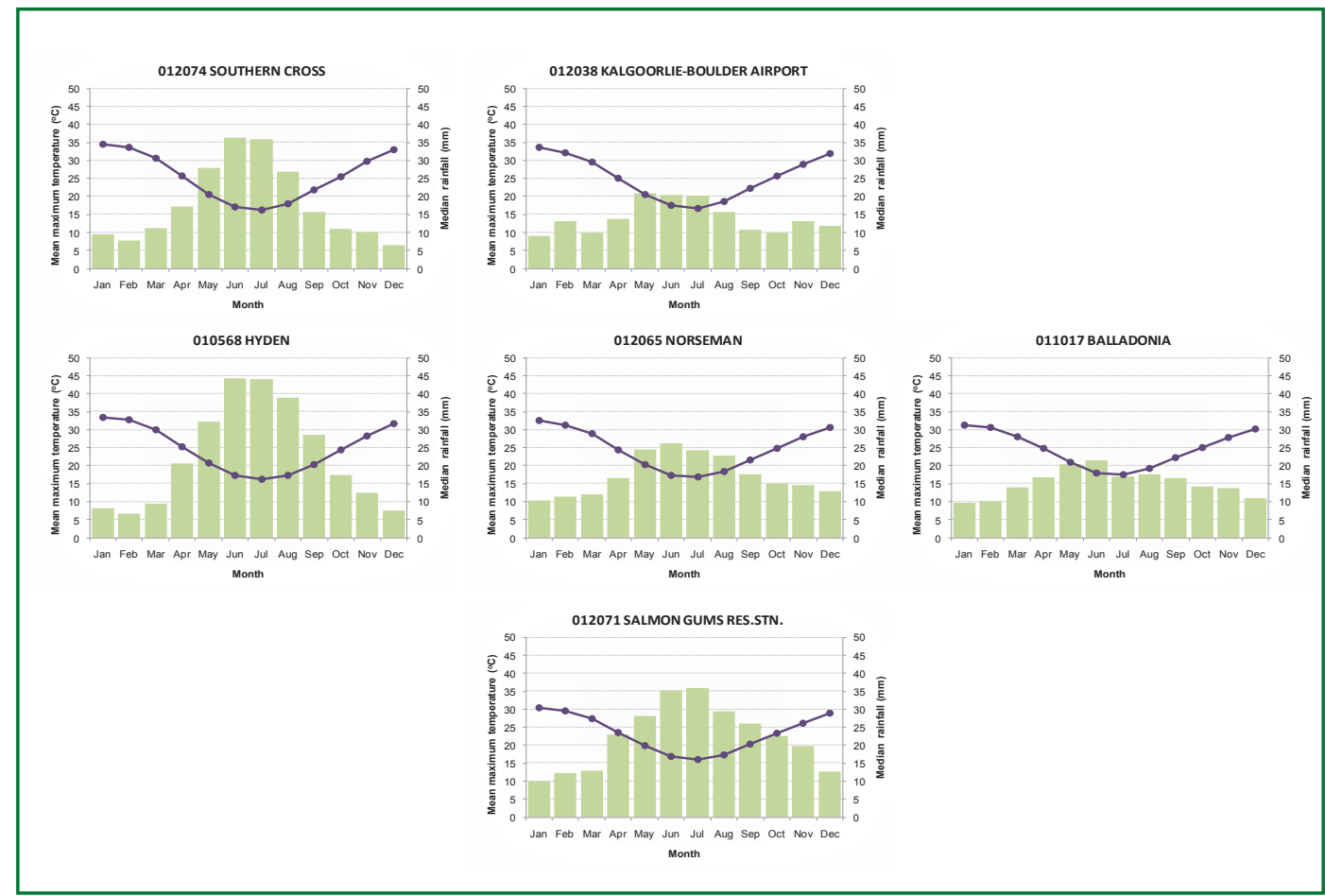

Figure 7.1 Mean maximum temperature (line) and median rainfall (columns) in the GWW region.

Data source: Bureau of Meteorology (<http://www.bom.gov.au/climate/data/index.shtml/>). This figure incorporates climate data that are Copyright Commonwealth of Australia 2009.

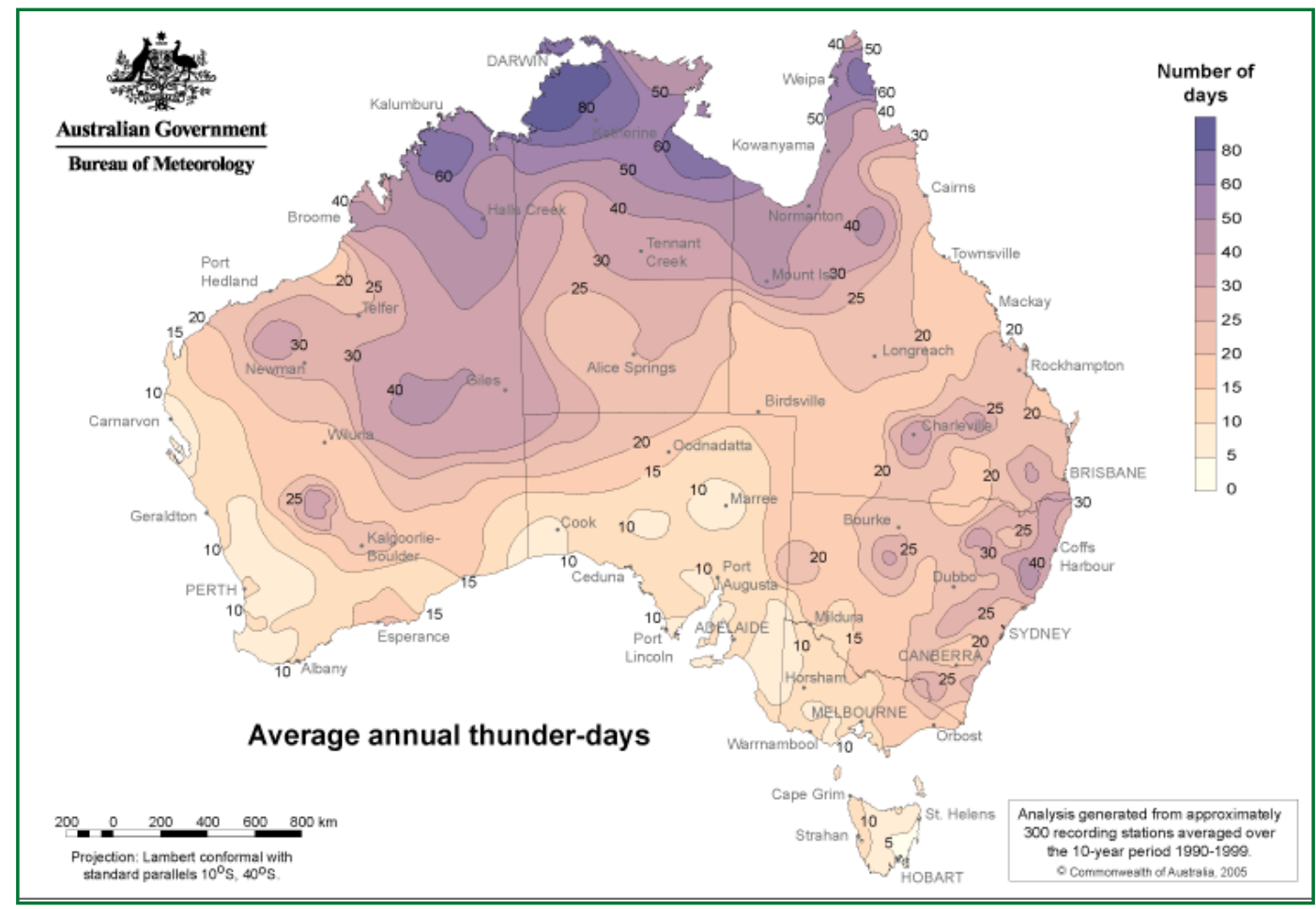

Figure 7.2 Average number of days (per annum) during which thunderstorms have been detected over a 10-year period (1990-99).

Data source: Bureau of Meteorology (<http://www.bom.gov.au/jsp/ncc/climate_averages/thunder-lightning/ index.jsp>, updated 7 October 2009), Copyright Commonwealth of Australia, reproduced by permission. 
Records of the Forests Department of Western Australia reveal that natural sources of ignition (lightning) historically caused from 1 to 6 per cent of fires in the south-western forests (Figure 7.3).

Fires ignited by humans can be accidental or deliberate. We define a deliberate fire as resulting from a person intentionally bringing burning material (such as a flaming match or an incendiary) into contact with fuel. Accidental ignitions can be further subdivided into: 1) passive fires ignited by, for example, fuel coming into contact with hot vehicle components, fuel heated by glass (discarded/broken bottles, and so on) that focuses solar radiation or flaming debris associated with blasting activities (NWCG 2005); 2) active fires ignited by careless use of burning materials-for example: cigarette butts or campfires. Deliberate fires can be subdivided into: i) legal ignitions-for example, prescribed burns and legal burn-offs; and ii) illegal ignitions-for example, illegal burnoffs and arson. All of these types of ignitions are reported to have caused fires in the south-western forests (Figure 7.3) and are likely to have also caused fires in the GWW.

Wind has an important role in spreading fire. It does this by bringing flames into contact with fuel, by providing a supply of oxygen, by removing moisture from the fuel and by transporting burning embers that can ignite spot fires up to $30 \mathrm{~km}$ distant from the fire front (Geoscience Australia 2009). Wind speeds of $12-15 \mathrm{~km} \mathrm{hr}^{-1}$ and higher greatly impact on fire spread and intensity (Geoscience Australia 2009). Wind speeds above the 12-15 $\mathrm{km} \mathrm{hr}^{-1}$ threshold are regularly attained in the GWW (Figure 7.4), although the one possible exception is the area closest to Hyden.

In summary, the fire conditions in the GWW consist of available fuel during hot, dry summers, wind as an agent of spread and some natural sources of ignition. The discontinuous fuel arrangement of original woodland vegetation might not generally have carried fire following natural ignitions before European settlement as the combination of conditions required for extensive wildfire events could have been lacking.

Because there is a lack of surface water in the GWW (see Table A2), Aboriginal people might have been absent from much of the area or present in only low densities during the hottest, driest, highest fire-danger months of the year. Historical observations of the habits of Aboriginal people of the GWW are scarce. In 1891, the Elder Exploring Expedition (Helms 1892-96) encountered only small groups of people as it moved through the western interior of Western Australia. Helms considered the people to be highly nomadic (and, in the Fraser Range region of the GWW, very undernourished) as a consequence of scant food resources. He observed that they were dependent solely on 'rock-holes' and 'native wells' for water during the dry season, which presumably limited their spatial range of movement. Rockholes are found mostly around granite outcrops. We assume that intentional burning by Aboriginal people would be limited to fires of low intensity and small spatial extent-for example, the firing of patches of spinifex grass (Triodia) to facilitate access to small marsupials that shelter within the tussock, as described by Helms (1892-96:255-6). The advent of mineral exploration, mining, the water pipeline, timber cutting, recreation and tourism has, however, resulted in a large increase in the potential sources of ignition that coincide with periods of high fuel availability and strong winds-conditions that allow intense, tree-killing fires to impact on the mature woodland vegetation. Subsequent post-fire successional changes in vegetation structure from woodland to dense shrubland (thickets of seedlings and root suckers) provide a more continuous fuel layer that is probably much more susceptible to fire than the woodland vegetation it replaces. 


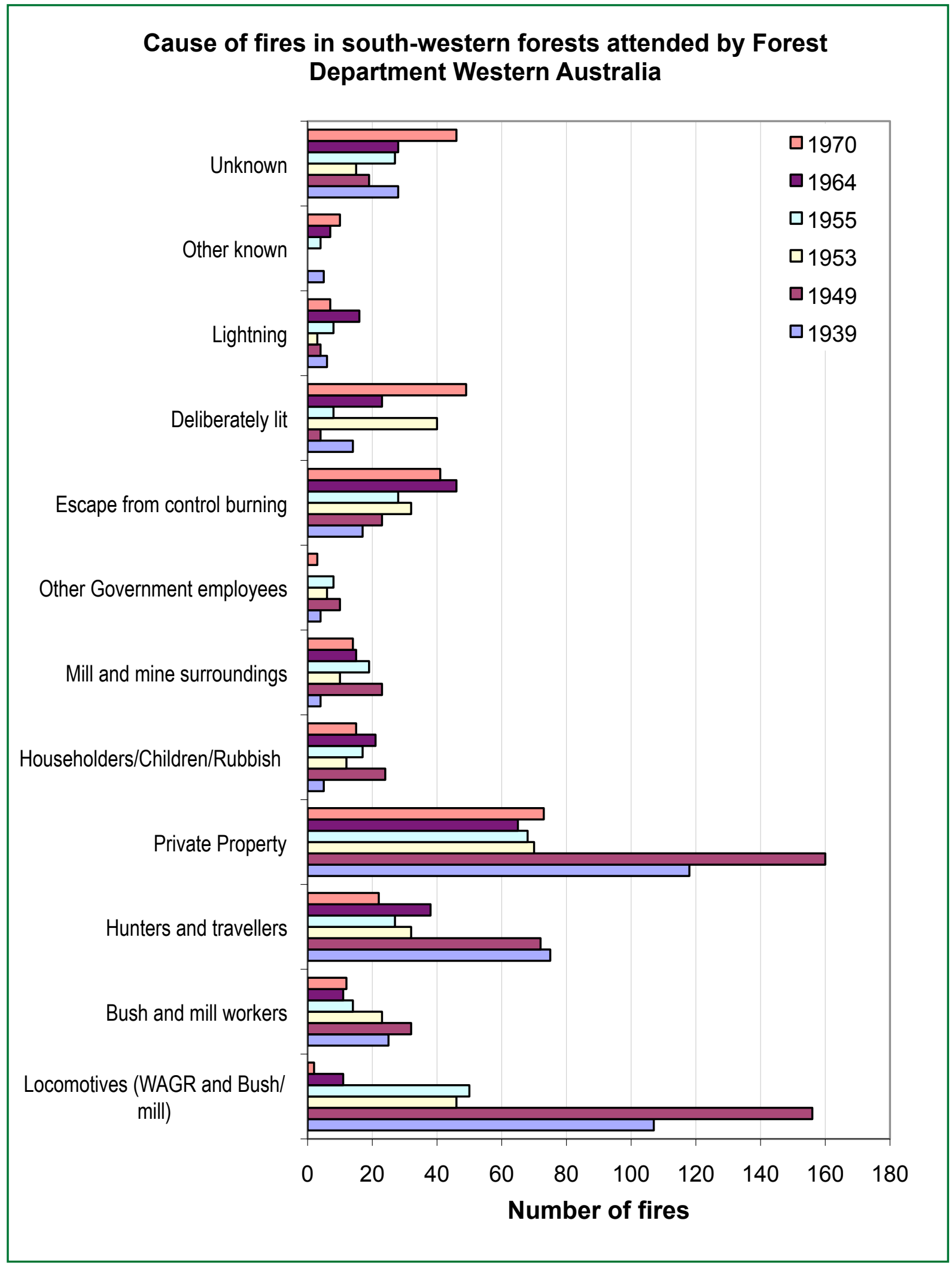

Figure 7.3 Historical causes of fire in the south-western forests of Western Australia.

Data source: Western Australia Forests Department (1934-70). 


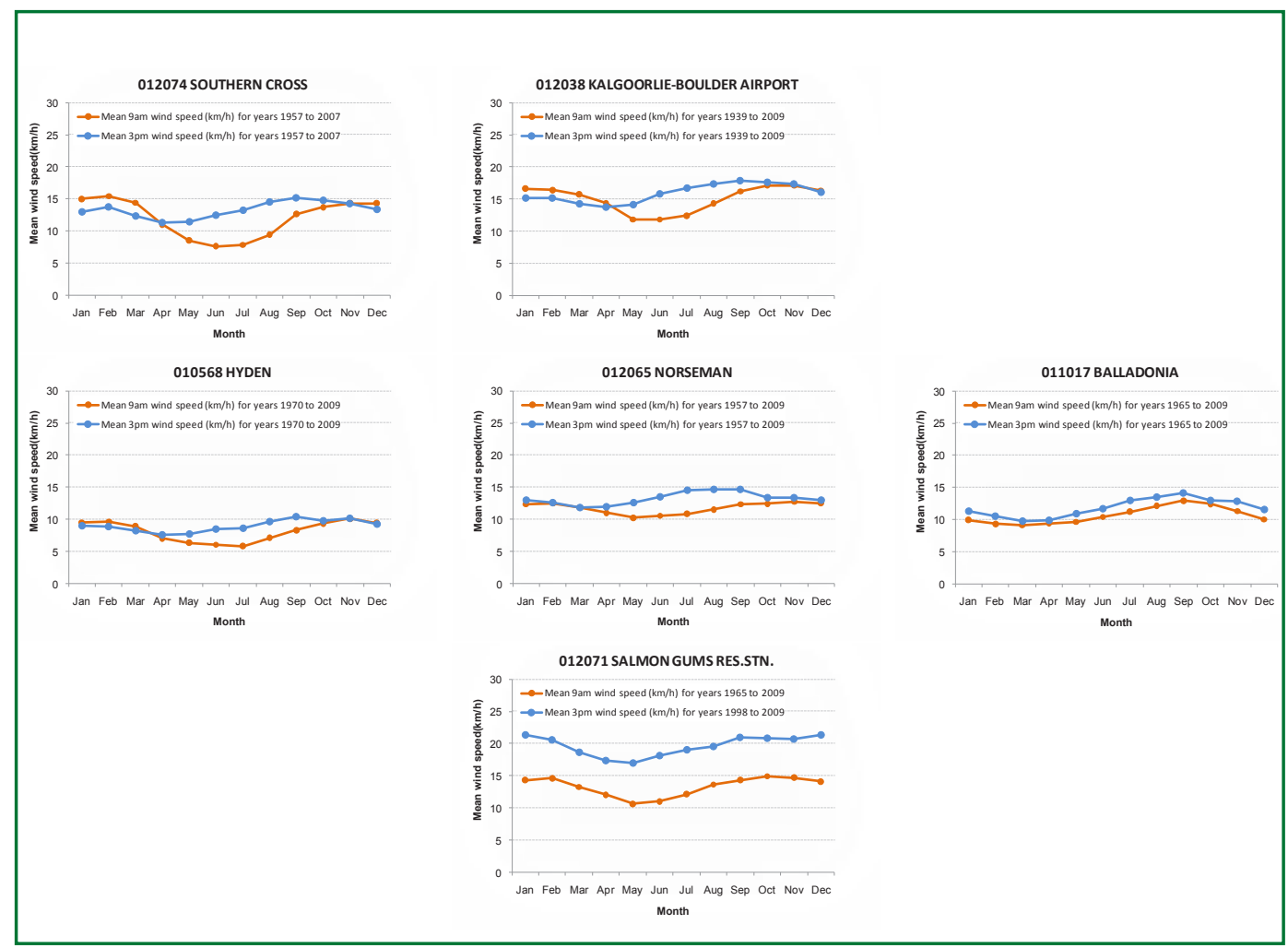

Figure 7.4 Mean wind speeds recorded in or near the GWW region.

Data source: Bureau of Meteorology (<http://www.bom.gov.au/climate/data/index.shtml/>). This figure incorporates climate data that are Copyright Commonwealth of Australia 2009.

\subsection{OPTIONS FOR FIRE MANAGEMENT IN THE GWW}

Protecting the current carbon stocks of the GWW will avoid emissions of carbon dioxide (a major greenhouse gas) from continuing disturbances. In addition, land management can be undertaken that promotes the restoration of current carbon stocks where they have been degraded so that the GWW begins to approach its carbon carrying capacity. To achieve these aims, two basic options can be considered.

\section{Do nothing}

If this option is taken then: 1) the areal extent of residual woodland is likely to decrease; and 2) fire will continue to prevent the pyric successional vegetation from attaining a mature successional stage with higher biomass carbon stocks.

\section{Regional planning and management}

Ideally, the entire region could be placed under a conservation planning overlay, perhaps analogous to how the Great Barrier Reef is managed in its entirety via zoning and associated management prescriptions. The most appropriate legal framework and policy instruments to achieve this remain to be identified. Given the aims of this report, we can only suggest some elements that should be considered as part of an integrated approach to management of the GWW. 
1. Change the tenure of the remaining long-unburnt woodland, currently under vacant crown land, to nature conservation reserve. This would make the WA Department of Environment and Conservation (WADEC) responsible for fires that are on or threaten the area. Based on information provided on the WADEC web site (viewed 24 March 2009, <http://www.dec.wa.gov.au/fire/ wildfires/wildfire-response.html>), we understand that WADEC is responsible only for fires that occur on lands that it manages, and on a 'good neighbour' basis for fires occurring near to or threatening land managed by WADEC. WADEC control, however, provides no guarantee that the woodlands will not burn, as suppression activities are difficult in this remote region. For example, an intense and extensive wildfire burned through woodland in the Dundas Nature Reserve in 2002-03. Additionally, the biomass carbon stocks of pyric successional vegetation would remain static or deteriorate with continued uncontrolled fire on land outside the reserve system.

2. Place all vacant crown lands ( $V C L$ ) within the $G W W$ into the nature conservation reserve system. As noted above, this would not guarantee protection from fire. It would, however, give WADEC responsibility for its management. Management activities could include selected road and access track closures and the imposition of total fire ban periods during the peak fire-danger period. We note that it may be impossible for a management authority such as WADEC to provide suppression of fires in this region given: 1) the remote location; 2) the distance from water sources; and 3) other regions within Western Australia are deemed to have higher priority during the peak fire season.

3. Establish an education campaign to reduce accidental and deliberate ignition events. If the VCL was placed under the control of WADEC, it could take responsibility for this education campaign. It would need to be targeted at field surveyors and exploration geologists, in addition to tourists and locals who use the GWW for recreation and other activities. A combination of the above approaches is likely to confer the greatest protection of the existing biomass carbon stock as well as allowing pyric successional vegetation to mature and consequently attain increased biomass carbon, thereby enabling the GWW to approach its carbon carrying capacity.

One important question remains: assuming that it is possible for succession to proceed, how long might it take for pyric successional shrubland of eucalypt seedlings and lignotuber re-sprouts to become woodland?

\subsection{ESTIMATED GROWTH RATE OF TREES IN THE GWW}

There have been no studies of the growth rates of eucalypt trees in the GWW. We do, however, have two types of information that can be used to inform estimates of tree age. First, during our field survey we collected five stem discs from fallen trees. These discs were taken from several metres up the stems as the lower stems had been hollowed out by termites. Stem sections were prepared from the discs and growth rings were counted to provide estimates of stem age. The data are presented in Table 7.1. Ring counts are related to stem crosssectional area, shown in Figure 7.5. 
Table 7.1 Estimated age of stem sections from eucalypt wood samples collected in the GWW. As the GWW has a distinct annual growing season (during winter/spring), the ring counts can be equated to age increments.

\begin{tabular}{c|c} 
Diameter under bark (cm) & $\begin{array}{c}\text { Ring count estimated equivalent age } \\
\text { (years) }\end{array}$ \\
\hline 29.4 & 169 \\
\hline 16.3 & 81 \\
\hline 9.2 & 66 \\
\hline 12.1 & 75 \\
\hline 17.0 & 78 \\
\hline
\end{tabular}

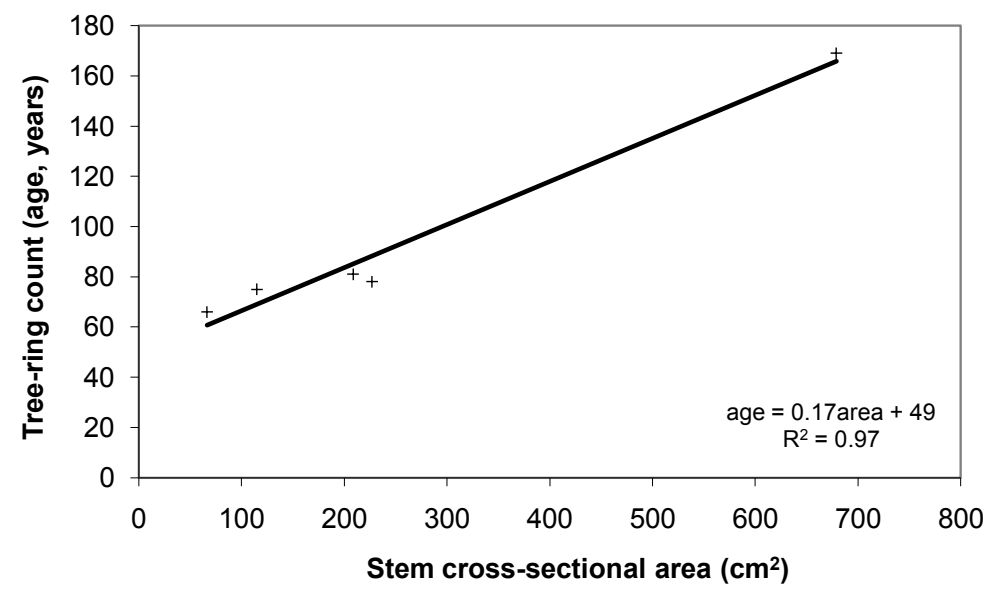

Figure 7.5 Relationship between tree-ring count and stem cross-sectional area (under bark) for GWW wood samples analysed by Dr Matt Brookhouse, ANU. The equation describes the line of best fit through the data points.

The second type of information comes from our field data measurements at Field Site 7, which include diameters of re-growth and coppice re-growth following timber cutting during the period 1921-38. The estimated age of the stems is between 67 and 84 years old. Estimates of age, using the regression equation in Figure 7.5, fall mostly within this age range (Figure 7.6). Twenty per cent of these stems give a greater than expected age.

This could mean that these trees are older and were not selected for harvest by timber cutters or that the growth rate of these stems was greater than average due to greater access to resources and less competition from neighbouring stems.

By applying the stem age to cross-sectional area relationship to the five field survey sites having long-unburnt vegetation and no timber harvesting, we have estimated a likely stand age. As the distributions of estimated age were similar for all five sites, we have combined the data to produce the histogram shown in Figure 7.7. The sites contain trees of mixed age-mostly from 100 to 400 years. A lifespan of several hundred years has previously been reported for eucalypt species in other parts of Australia (Looby 2007; Ogden 1978; Wellington and Noble 1985). All five sites contained some trees that were very large and possibly very ancient. 


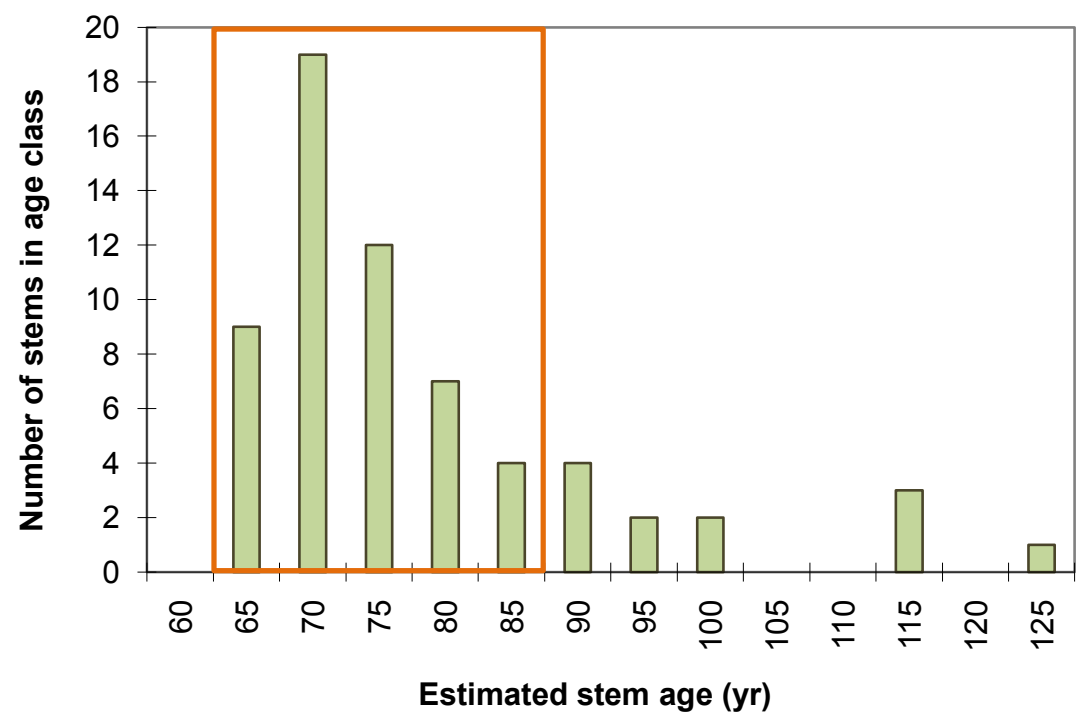

Figure 7.6 Estimated age of coppice stems measured at Field Survey Site 7 in 2005. The coppice stems have re-grown following timber cutting between 67 and 84 years before our field survey. The orange rectangle indicates those stems with an age estimate that falls within the boundaries expected from the timber-cutting data.

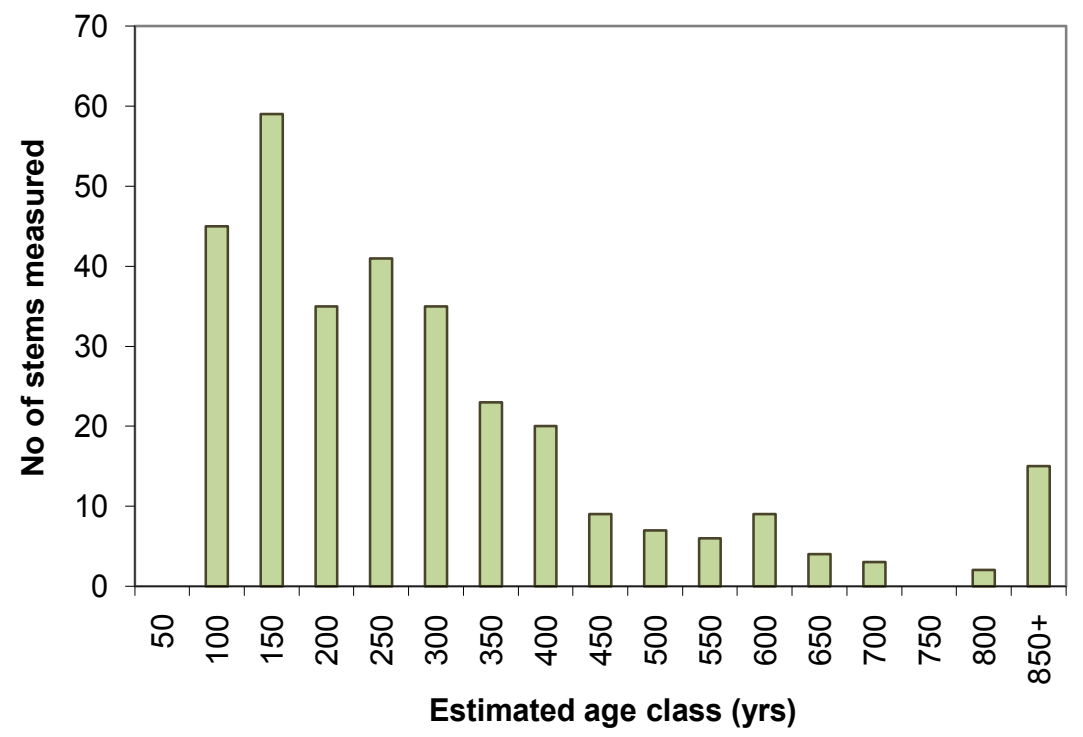

Figure 7.7 Estimated age class for trees measured at Field Survey Sites 6, 12, 13, 15 and 20. These sites showed no signs of recent disturbance from fire, timber cutting or prospecting.

This brief investigation of tree growth rates and ages suggests that it could take several centuries for the completion of pyric succession and for biomass carbon to reach maximum levels. This can be achieved only if intense and frequent fires are successfully excluded from extensive areas of the GWW. 


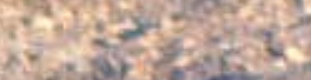 \\ $4=15$

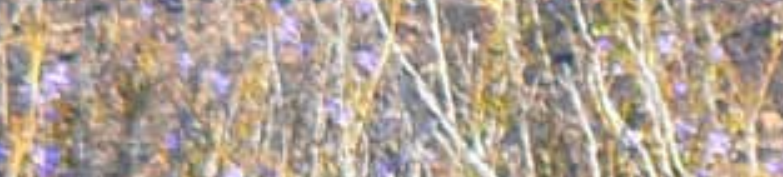

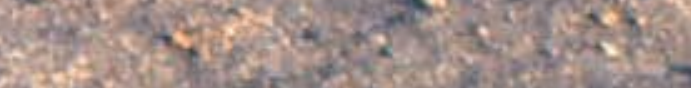
2, 4. 


\section{CONCLUSION}

In this report, we have quantified the carbon dynamics of the GWW with sufficient accuracy to support consideration of management options for actions that will help protect current carbon stocks and begin to restore the region's carbon carrying capacity. While 'no fire' could be a desirable management option, we accept that this is an unrealistic expectation and that fires will occur irrespective of the management efforts. Therefore, the most feasible goals are probably minimisation of human ignitions and partial suppression of lightning ignitions, through tenure and land-use management changes.

Implementing these management options will, however, come at a cost. Conservation management options are more likely to succeed if they can be linked to the emerging carbon market and payments for land stewardship and ecosystem services. The emerging carbon economy provides a potential source of investments for protecting and restoring green carbon stocks in the GWW. Voluntary carbon offset schemes involving changes to land management are already under way in parts of Australia (for exampleshttp://www.carbonoffsetguide.com.au/>). Furthermore, consideration is being given to forest mitigation schemes based on payment for ecosystem services and land stewardship (Costa 2009). Therefore, it is important that state, Commonwealth and international policies and actions recognise the value of avoiding emissions from extant carbon stocks in natural ecosystems, along with the sequestration potential from managing threatening processes. Incentives are needed that will enhance carbon stocks in the GWW through ecological restoration, while avoiding perverse outcomes such as inadvertently providing incentives to clear and degrade natural vegetation ecosystems.

If regions such as the GWW are to be included in carbon market schemes, precise estimates of spatial and temporal changes in carbon stocks will be required. Consequently, there will be a need to establish a network of long-term sites where all components of the carbon stock, including soil organic carbon, are monitored. 


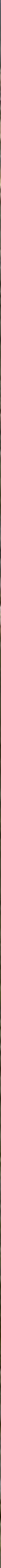




\section{APPENDIX}

\section{CALCULATION OF ABSOLUTE DENSITY OF INDIVIDUALS MAKING UP A CANOPY LAYER FROM INTENSIVE SITE DATA}

For a detailed description of the methodology, see Mitchell (2007).

For each sampled canopy layer at each field site the sum of distances, $D_{n^{\prime}}$, is:

$D_{n}=\sum_{i=1}^{16} \sum_{j=1}^{4} R_{i j}$

in which

$i$ is a particular transect point $(1-16)$

$j$ is a quarter at a transect point (1-4)

$n$ is the number of quarters in which a measurement is made

$\mathrm{n}_{0}$ is the number of vacant or empty quarters

$R_{i j}$ is the point-to-plant centre distance at point $i$ in quarter $j$

The mean distance, $\bar{r}$, is:

$\bar{r}=\frac{D_{n}}{n}$

Case 1. $\mathrm{n}_{0}=0$

The absolute density, $\lambda$, is:

$\lambda=\frac{1}{\overline{r^{2}}}$ plants $\mathrm{m}^{-2}$

$\lambda=\frac{10000}{\overline{r^{2}}}$ plants $\mathrm{ha}^{-1}$

\section{Case 2. $\mathrm{n}_{0}>0$}

In this case, a correction factor (CF) is applied. First, it is necessary to calculate the ratio

$\frac{n_{0}}{n+n_{0}}$

Then, using the look-up table (Table 1 provided in Warde and Petranka 1981), find the CF that applies to this ratio.

The absolute density, $\lambda$, is:

$\lambda=\frac{1}{r^{2}} C F$ plants $\mathrm{m}^{-2}$

$\lambda=\frac{10000}{\overline{r^{2}}} C F$ plants $\mathrm{ha}^{-1}$ 


\section{CALCULATION OF THE BASAL AREA OF THE TREE LAYERS FROM INTENSIVE SITE DATA}

For each sampled canopy layer at each field site the sum of the cross-sectional area of the measured stems, $A_{n}$, is:

$A_{n}=\sum_{i=1}^{16} \sum_{j=1}^{4} \pi r^{2}{ }_{i j}$

in which $r$ is the stem radius at $1.3 \mathrm{~m}$ (that is, stem $\mathrm{dbh} / 2$ ).

In the case of multi-stemmed individuals, the cross-sectional area of each stem was calculated, and the plant cross-sectional area was calculated as the sum of the areas of the individual stems making up the plant.

The mean plant stem cross-sectional area, $\bar{A}$, is:

$\bar{A}=\frac{A_{n}}{n}$

in which $\mathrm{n}$ is the number of quarters in which a measurement was made.

The basal area, $\mathrm{B}$, is:

$B=\bar{A} \lambda$

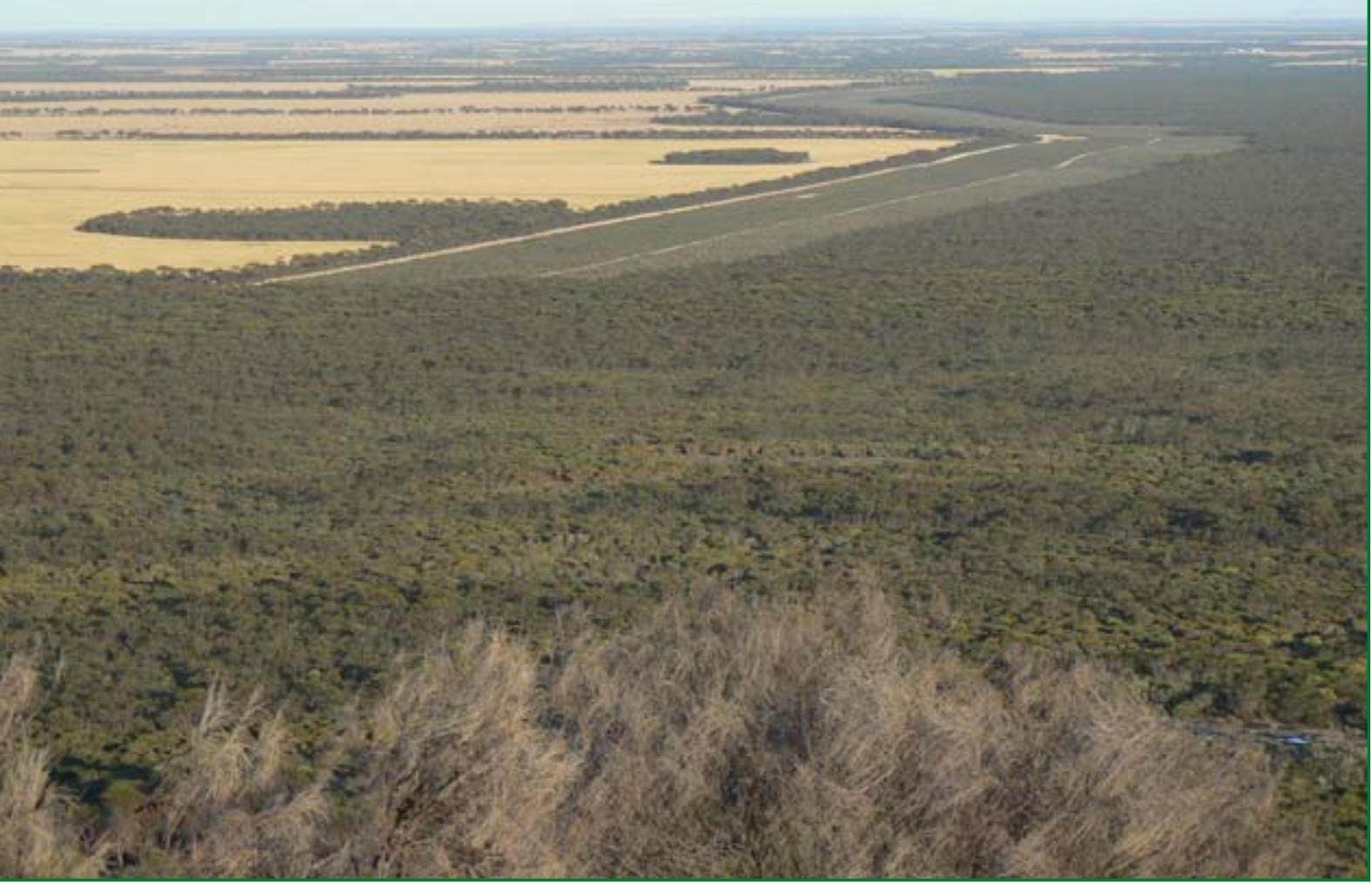


Table A1 Description of spacial data layers used for model development and extrapolation.

$\begin{array}{ccc}\text { Name or symbol } \quad \text { Layer description } & \begin{array}{c}\text { Spatial } \\ \text { resolution }\end{array} & \text { Source }\end{array}$

\section{Topography and administrative}

\begin{tabular}{|c|c|c|c|}
\hline Elevation & $\begin{array}{l}\text { Ground-level elevation: Digital } \\
\text { Elevation Model Version } 3\end{array}$ & 9 second & Hutchinson et al. (2008) \\
\hline Topo & $\begin{array}{l}\text { Topographic position index: } \\
\text { calculated from the 9-second digital } \\
\text { elevation model }\end{array}$ & $250 \mathrm{~m}$ & Gallant and Dowling (2003) \\
\hline Land tenure & Australian Land Tenure 1993 & 1:5000000 & $\begin{array}{l}\text { Geoscience Australia } \\
\text { (1993) }\end{array}$ \\
\hline Roads & WA Roads & $1: 5000000$ & $\begin{array}{l}\text { Geological Survey of } \\
\text { Western Australia (2007) }\end{array}$ \\
\hline Towns & Population Centres & 1:1000000 & Lawford et al. (1998) \\
\hline Map sheet & 1:250 000 Map Sheet Index & $1: 250000$ & $\begin{array}{l}\text { Geological Survey of } \\
\text { Western Australia (2007) }\end{array}$ \\
\hline \multicolumn{4}{|c|}{ Climate } \\
\hline $\mathrm{R}_{\mathrm{s}}$ & $\begin{array}{l}\text { Solar radiation received at the } \\
\text { surface, } \mathrm{MJ} \mathrm{m}^{-2} \mathrm{yr}^{-1}\end{array}$ & $1 \mathrm{~km}$ & Hutchinson (2005) \\
\hline$P$ & Mean annual precipitation, $\mathrm{mm} \mathrm{yr}^{-1}$ & $1 \mathrm{~km}$ & Hutchinson (2005) \\
\hline $\mathrm{T}_{\max }$ and $\mathrm{T}_{\min }$ & $\begin{array}{l}\text { Mean daily air temperature in } \\
\text { January (Tmax) and July (Tmin), ' } \mathrm{C}\end{array}$ & $1 \mathrm{~km}$ & Hutchinson (2005) \\
\hline W & $\begin{array}{l}W=P-\frac{R_{s}}{\rho L} \mathrm{~mm} \mathrm{yr}^{-1} \text {, in which } \rho \text { is } \\
\text { the density of liquid } \\
\text { water }\left(\sim 1000 \mathrm{~kg} \mathrm{~m}^{-3}\right) \text { and } \mathrm{L} \text { is the } \\
\text { latent heat of vaporisation of water } \\
\left(\sim 2.45 \times 10^{6} \mathrm{~J} \mathrm{~kg}^{-1} \mathrm{H}_{2} \mathrm{O}\right) \mathrm{W}_{3000}=\mathrm{W}+ \\
3000 \mathrm{~mm} \mathrm{yr}^{-1} . \mathrm{W}_{4000}=\mathrm{W}+4000 \mathrm{~mm} \mathrm{yr}^{-1}\end{array}$ & $1 \mathrm{~km}$ & $\begin{array}{l}\text { Berry and Roderick } \\
(2002)\end{array}$ \\
\hline \multicolumn{4}{|c|}{ Vegetation } \\
\hline NVEG & Natural vegetation & 1:5 million & AUSLIG (1990) \\
\hline PVEG & Present vegetation & 1:5 million & AUSLIG (1990) \\
\hline MVG & $\begin{array}{l}\text { National Vegetation Information System. } \\
\text { Australia-Present Major Vegetation } \\
\text { Groups_NVIS Stage 1, Version } 3.0\end{array}$ & $100 \mathrm{~m}$ & DEWHA (2005) \\
\hline MODIS & $\begin{array}{l}\text { Normalised Difference Vegetation } \\
\text { Index }\end{array}$ & & \\
\hline $\begin{array}{l}\text { MODIS 16-Day } \\
\text { L3 Global 250m } \\
\text { (MOD13Q1) } \\
\text { satellite imagery }\end{array}$ & $250 \mathrm{~m}$ & $\begin{array}{l}\text { Paget } \\
\text { and King } \\
(2008)\end{array}$ & \\
\hline Fire mapping & $\begin{array}{l}\text { Landsat MSS, TM and ETM+ satellite } \\
\text { data 1972-2002 }\end{array}$ & $30 \mathrm{~m}$ & Geoscience Australia (2010) \\
\hline WA land cover & Landsat WA 2005 & & $\begin{array}{l}\text { Geological Survey } \\
\text { of Western Australia (2007) }\end{array}$ \\
\hline Timber cutting & $\begin{array}{l}\text { Timber tramlines and cutting areas } \\
\text { in the Goldfields region, } 1900-75 . \text { FD } \\
\text { No. } 1610\end{array}$ & $1: 500000$ & $\begin{array}{l}\text { The digitised layer was } \\
\text { created from the } \\
\text { printed map }\end{array}$ \\
\hline
\end{tabular}


Table A1 Continued.

\begin{tabular}{|c|c|c|c|}
\hline \multicolumn{3}{|c|}{ Name or symbol } & Source \\
\hline \multicolumn{4}{|c|}{ Geology } \\
\hline Geology & Geology of Western Australia & $1: 250000$ & $\begin{array}{l}\text { Geological Survey of } \\
\text { Western Australia (2007) }\end{array}$ \\
\hline Lithology & Surface lithology & $1: 500000$ & $\begin{array}{l}\text { Geological Survey of } \\
\text { Western Australia (2007) }\end{array}$ \\
\hline$\% \mathrm{OC}$ & Soil carbon concentration of A and B horizons (\% C) & $1 \mathrm{~km}$ & CSIRO (2007) \\
\hline Thick $_{A^{\prime}}$ Thick $_{B}$ & Thickness of $A$ and $B$ horizons (m) & $1 \mathrm{~km}$ & CSIRO (2007) \\
\hline $\mathrm{BD}_{\mathrm{A}^{\prime}}, \mathrm{BD}_{\mathrm{B}}$ & Soil bulk density of $\mathrm{A}$ and $\mathrm{B}$ horizons $\left(\mathrm{Mg} \mathrm{m}^{-3}\right)$ & $1 \mathrm{~km}$ & CSIRO (2007) \\
\hline Thick $_{A B}$ & Thick $_{A B}=$ Thick $_{A}+\operatorname{Thick}_{B}(\mathrm{~m})$ & $1 \mathrm{~km}$ & \\
\hline $\mathrm{SOC}_{\mathrm{A}}$ & $\mathrm{SOC}_{\mathrm{A}}=\mathrm{Thick}_{\mathrm{A}} \mathrm{BD}_{\mathrm{A}} \frac{\% \mathrm{OC}}{100} \quad\left(\mathrm{~kg} \mathrm{C} \mathrm{m}^{-2}\right.$ of ground surface $)$ & $1 \mathrm{~km}$ & \\
\hline $\mathrm{SOC}_{\mathrm{B}}$ & $\mathrm{SOC}_{\mathrm{B}}=$ Thick $_{\mathrm{B}} \mathrm{BD}_{\mathrm{B}} \frac{\% \mathrm{OC}}{100} \quad\left(\mathrm{~kg} \mathrm{C} \mathrm{m}^{-2}\right.$ of ground surface) & $1 \mathrm{~km}$ & \\
\hline
\end{tabular}




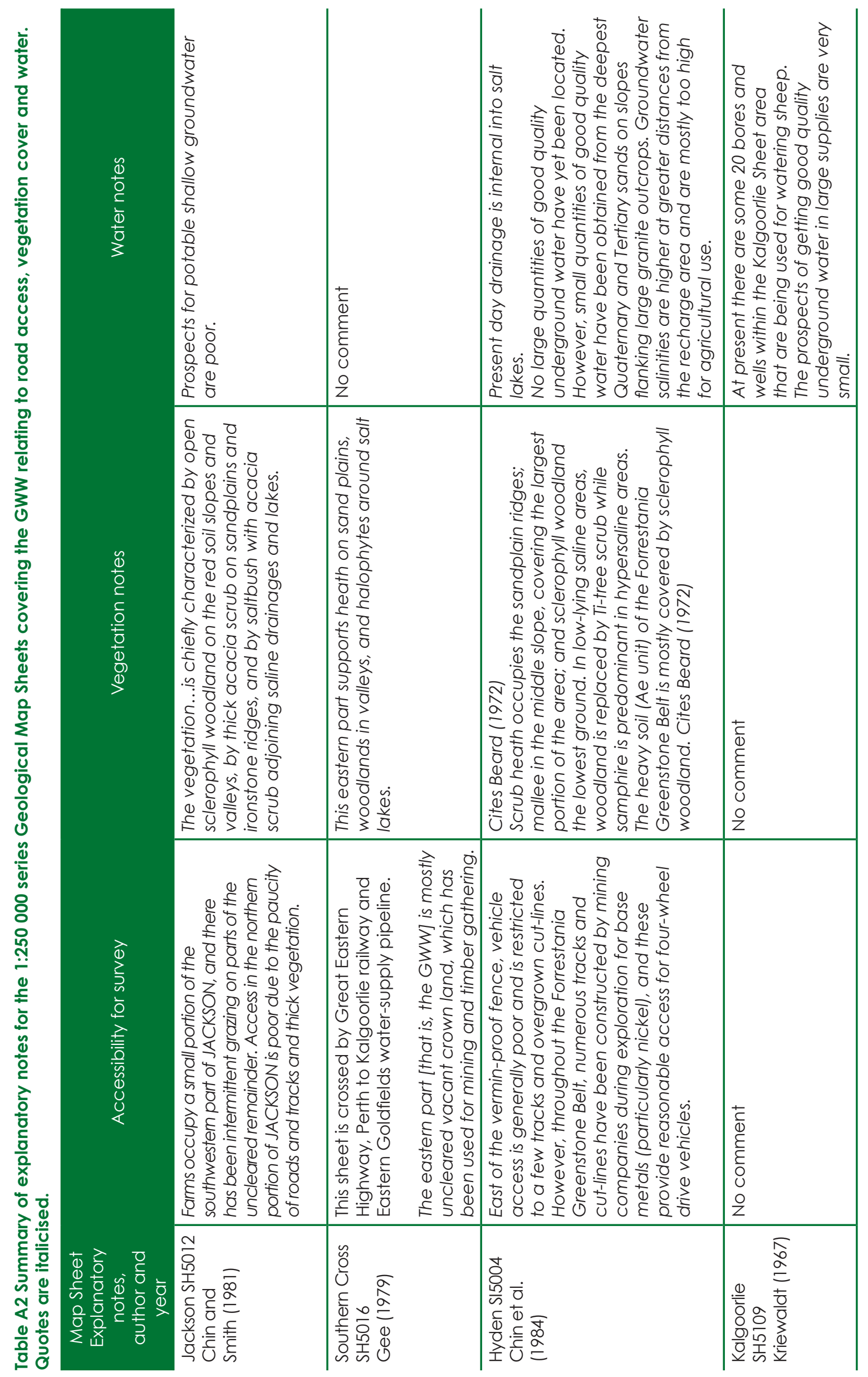

(2) 


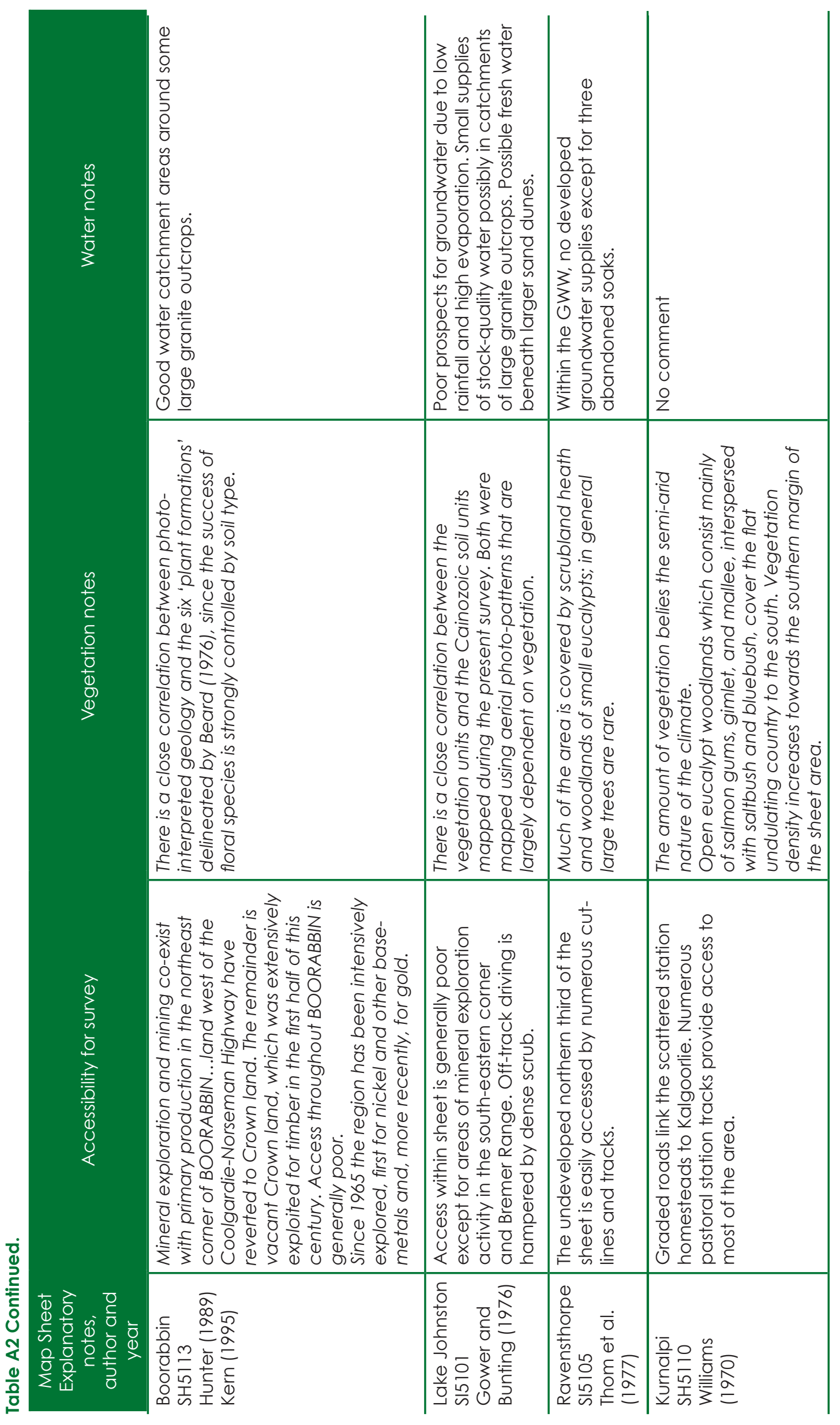

() 


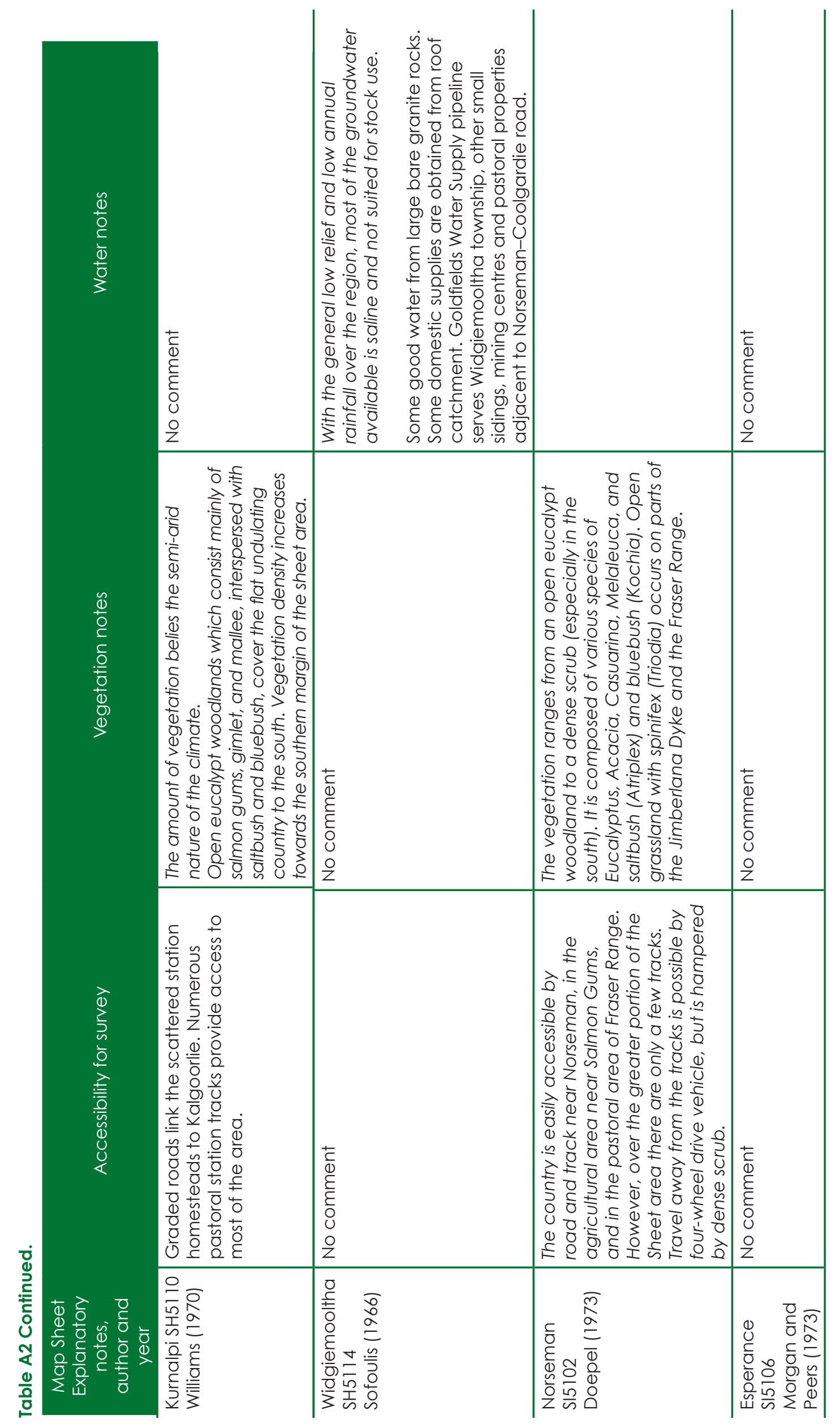

() 


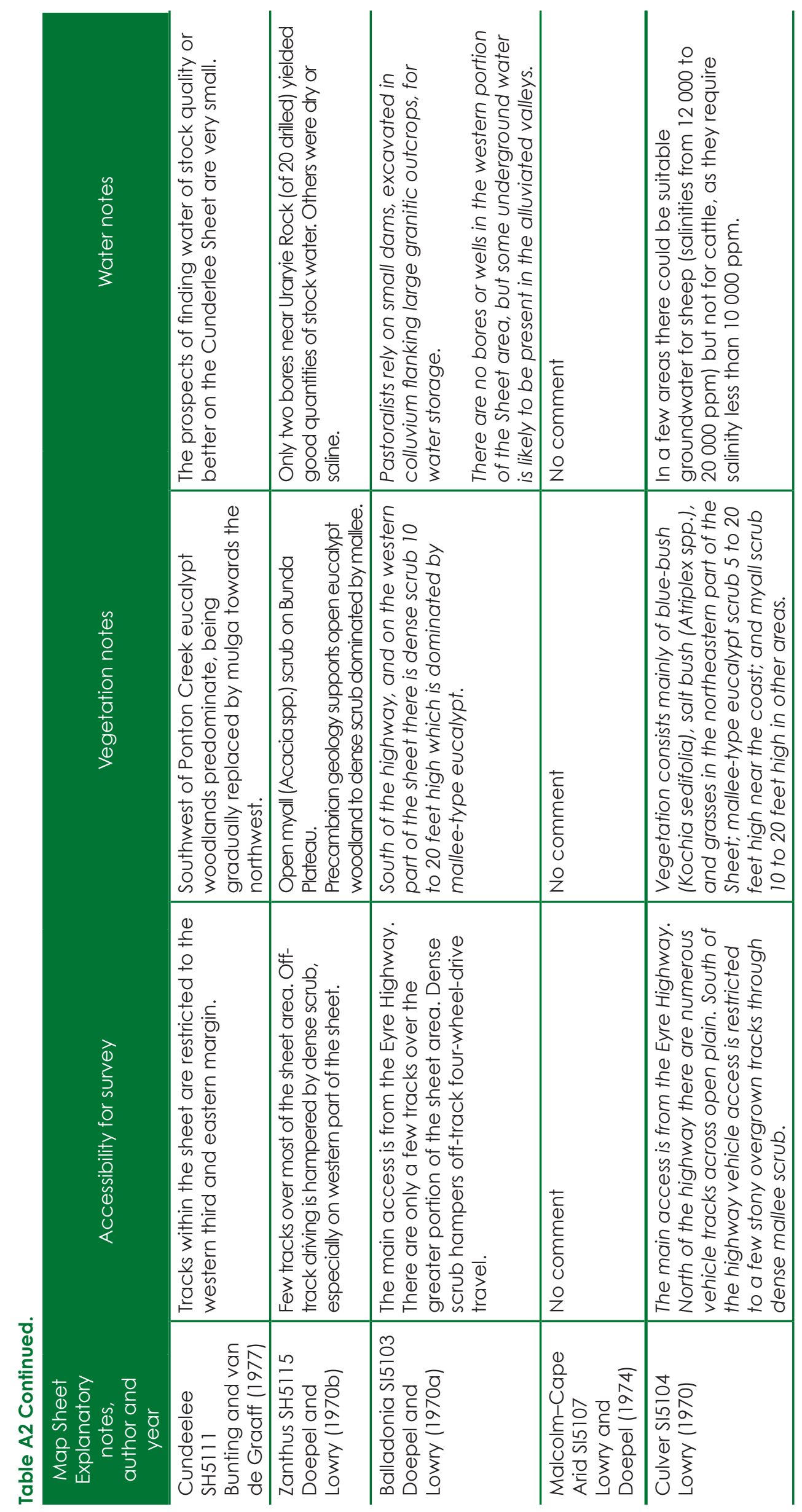

() 


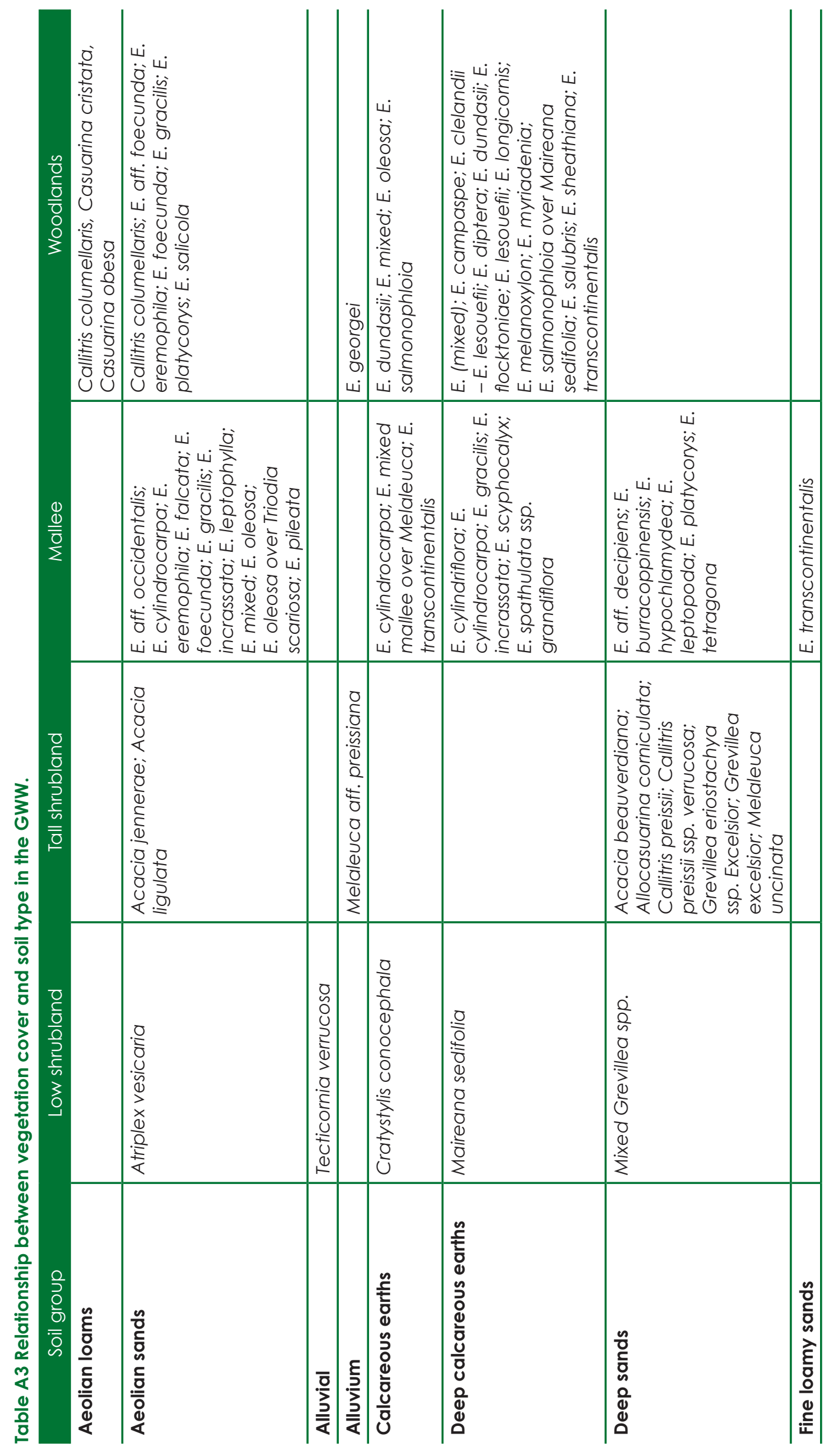

(2) 


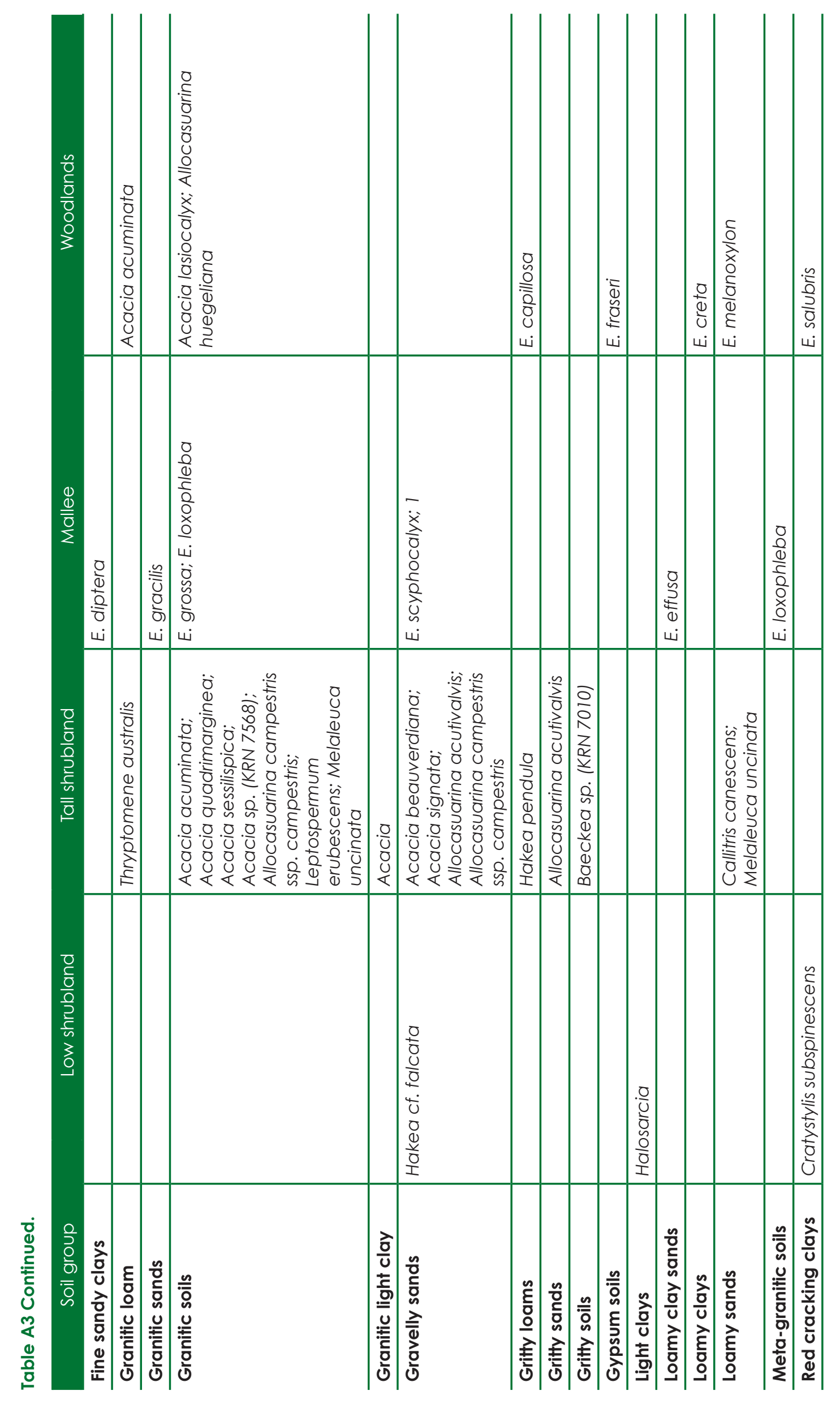




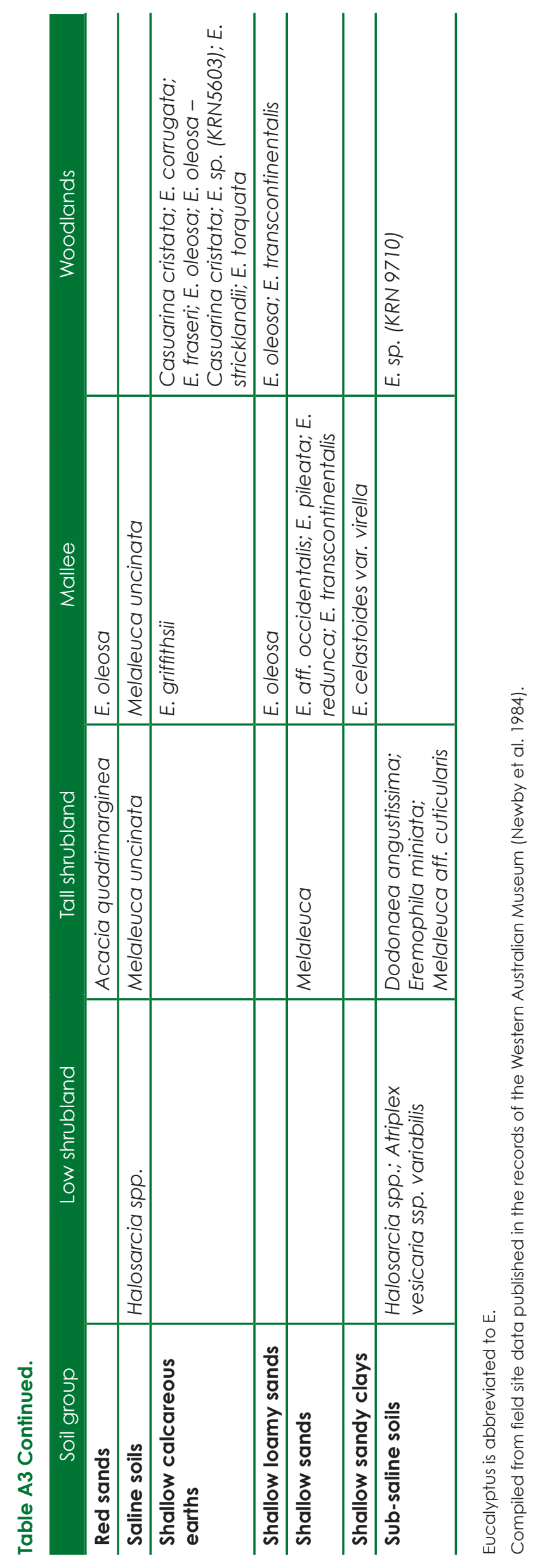

() 


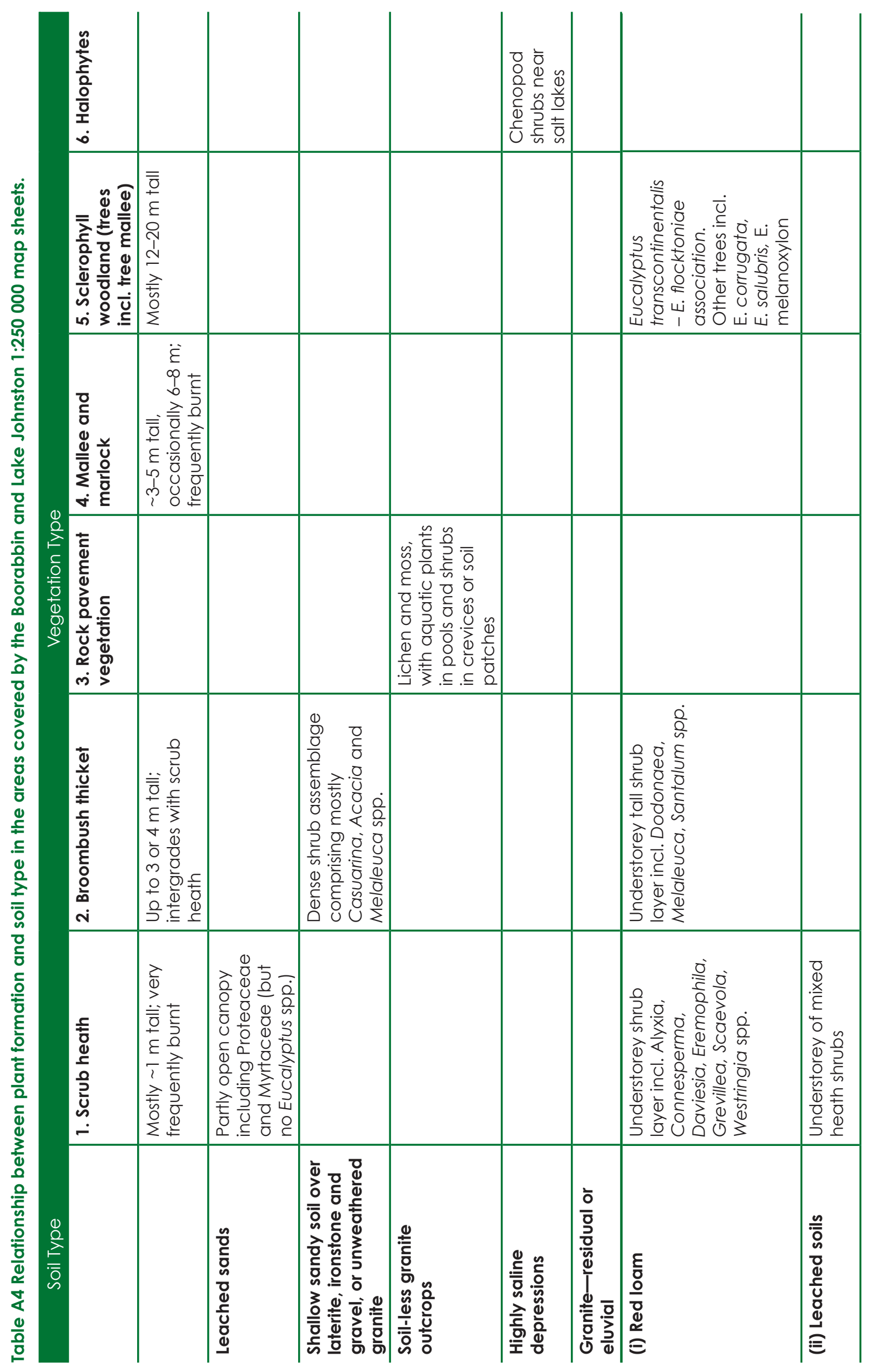

(2) 


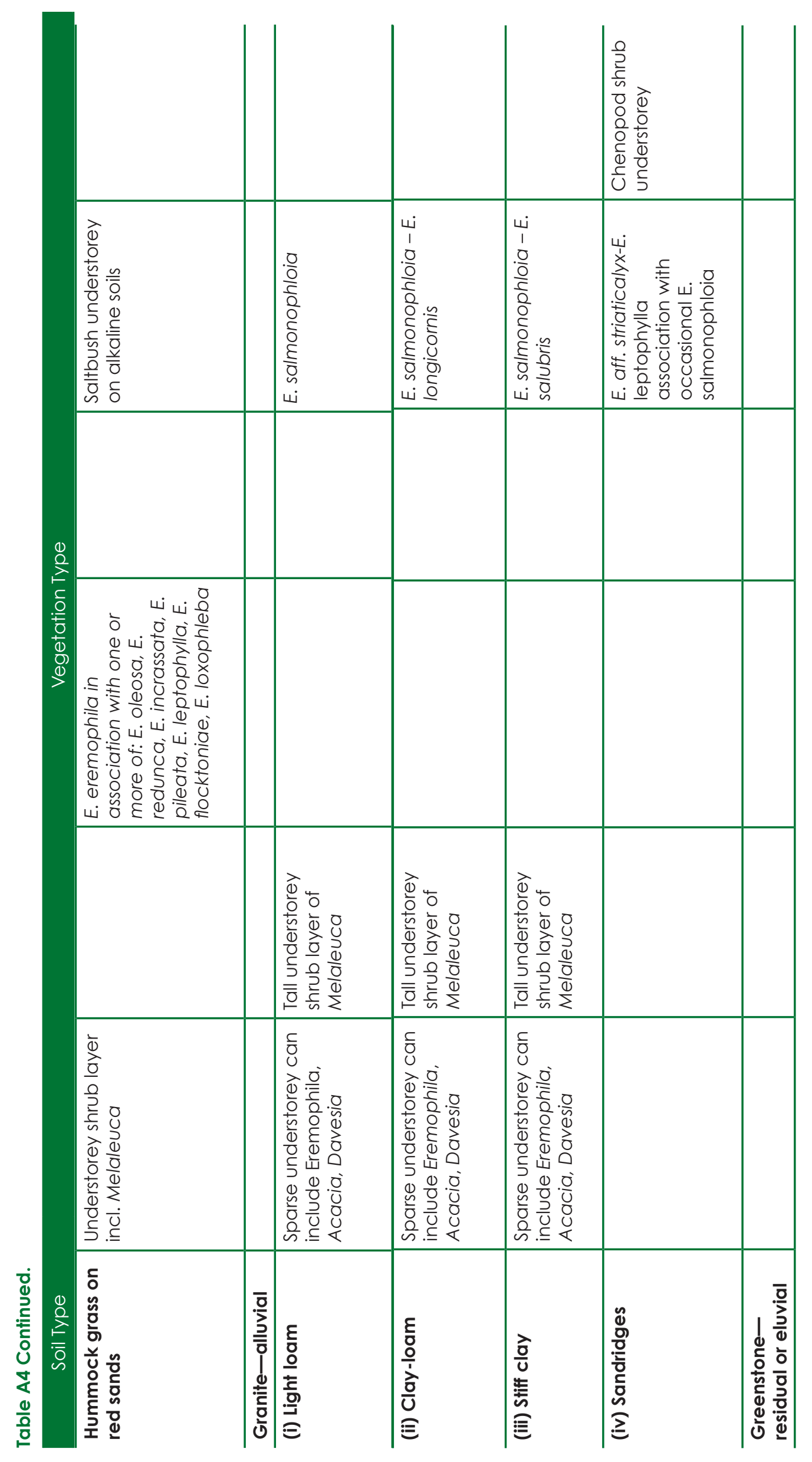

() 


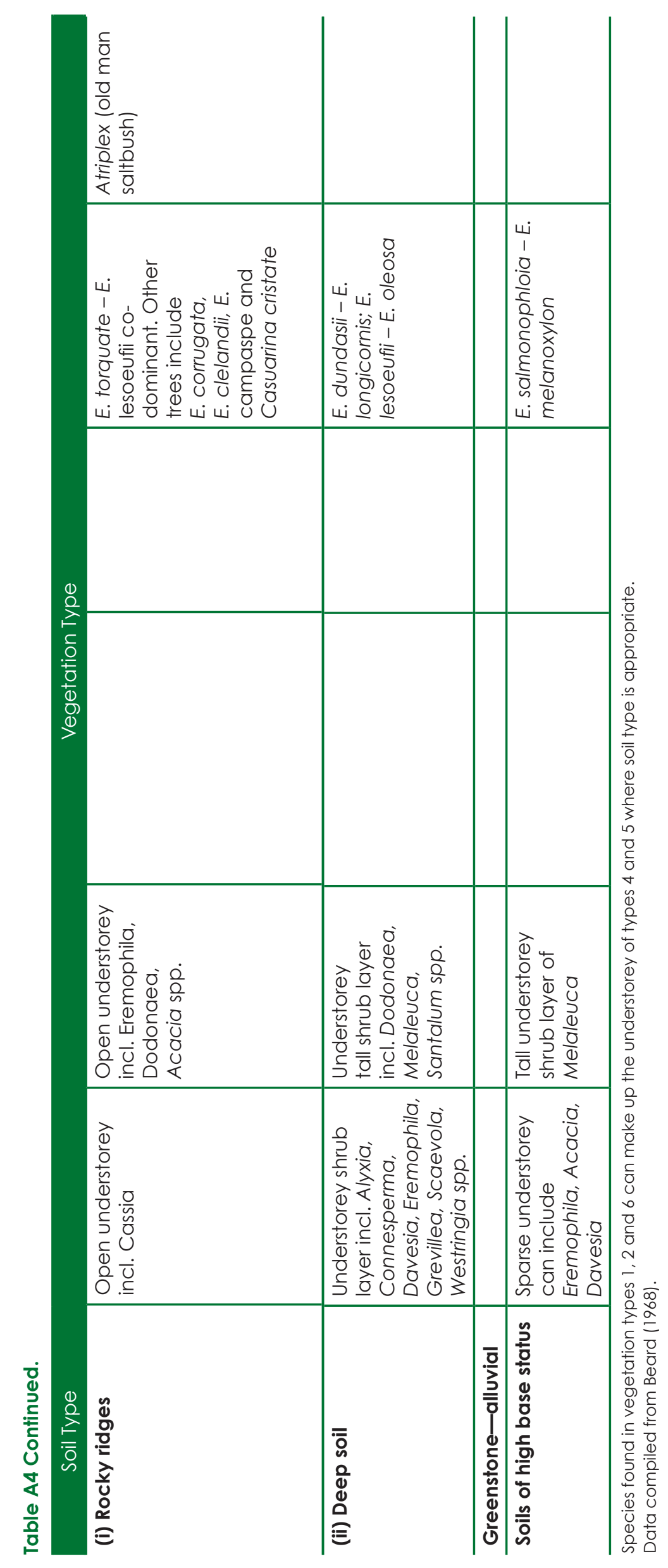

() 


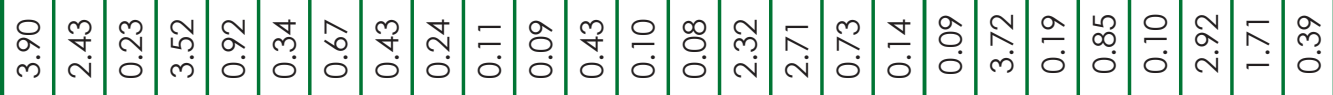

o

is

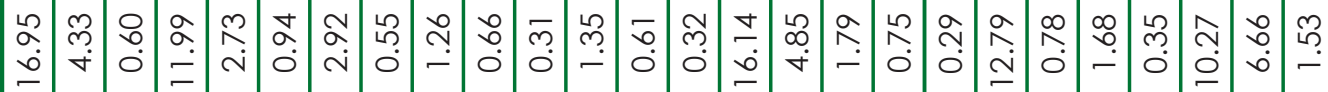

O

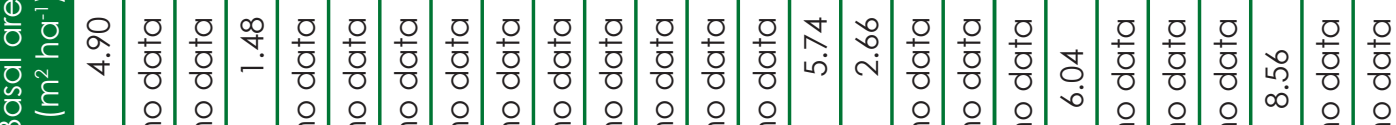

ठำ

○

○

กิ

용

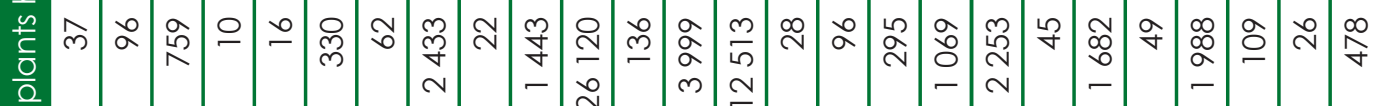

.ำ

ริำ

$\sum_{0}^{3}$

4

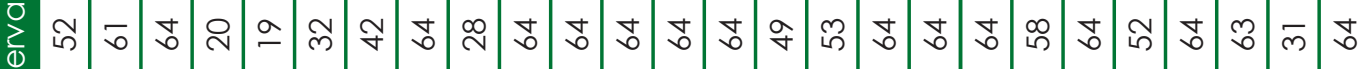

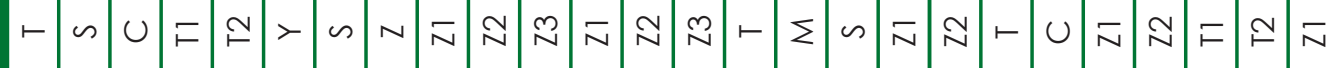




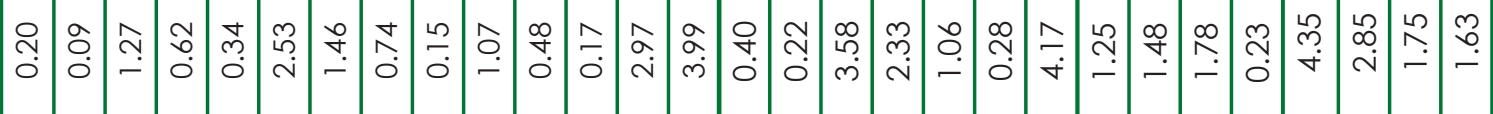

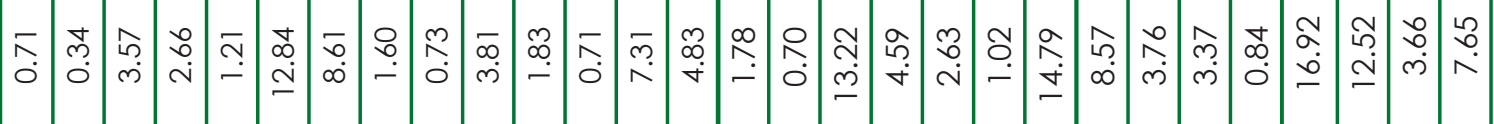

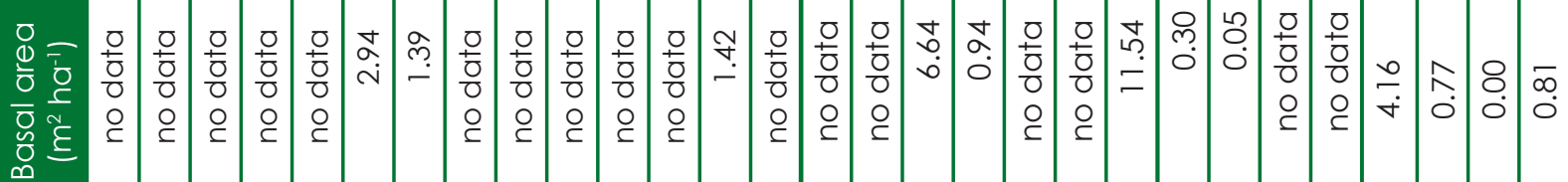

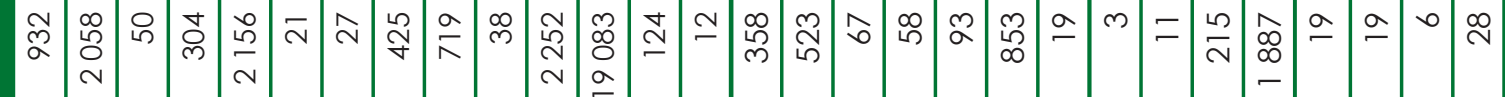

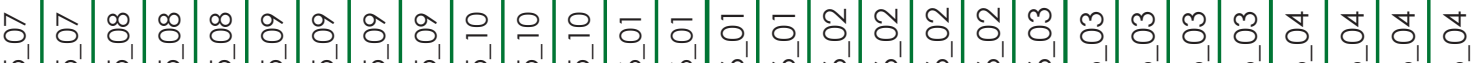

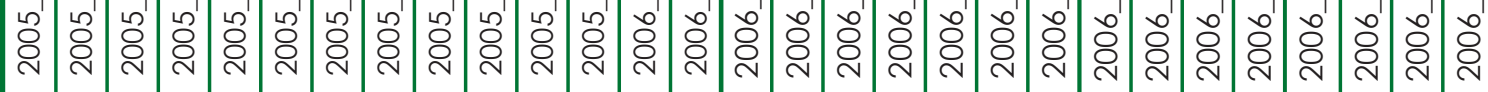




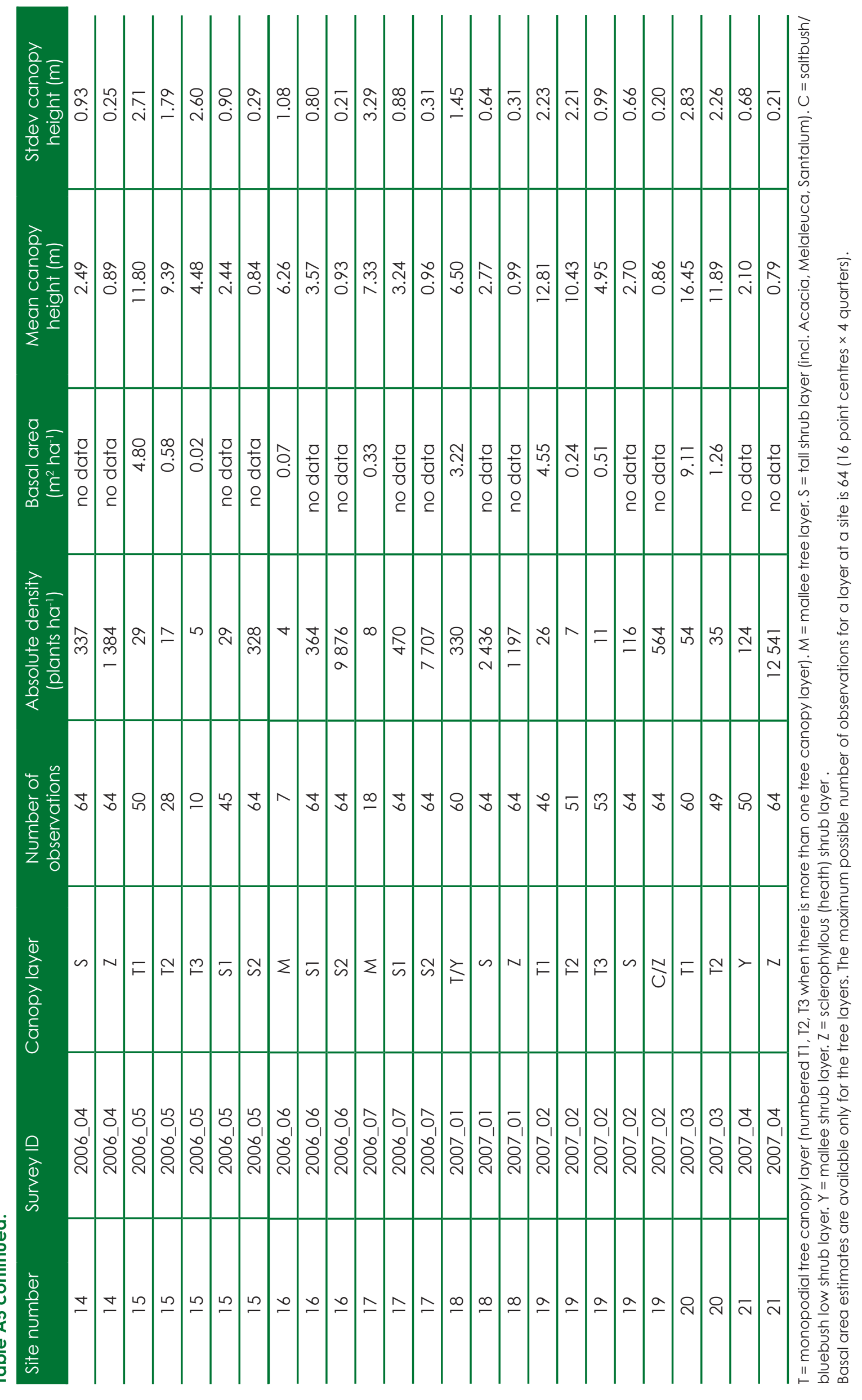




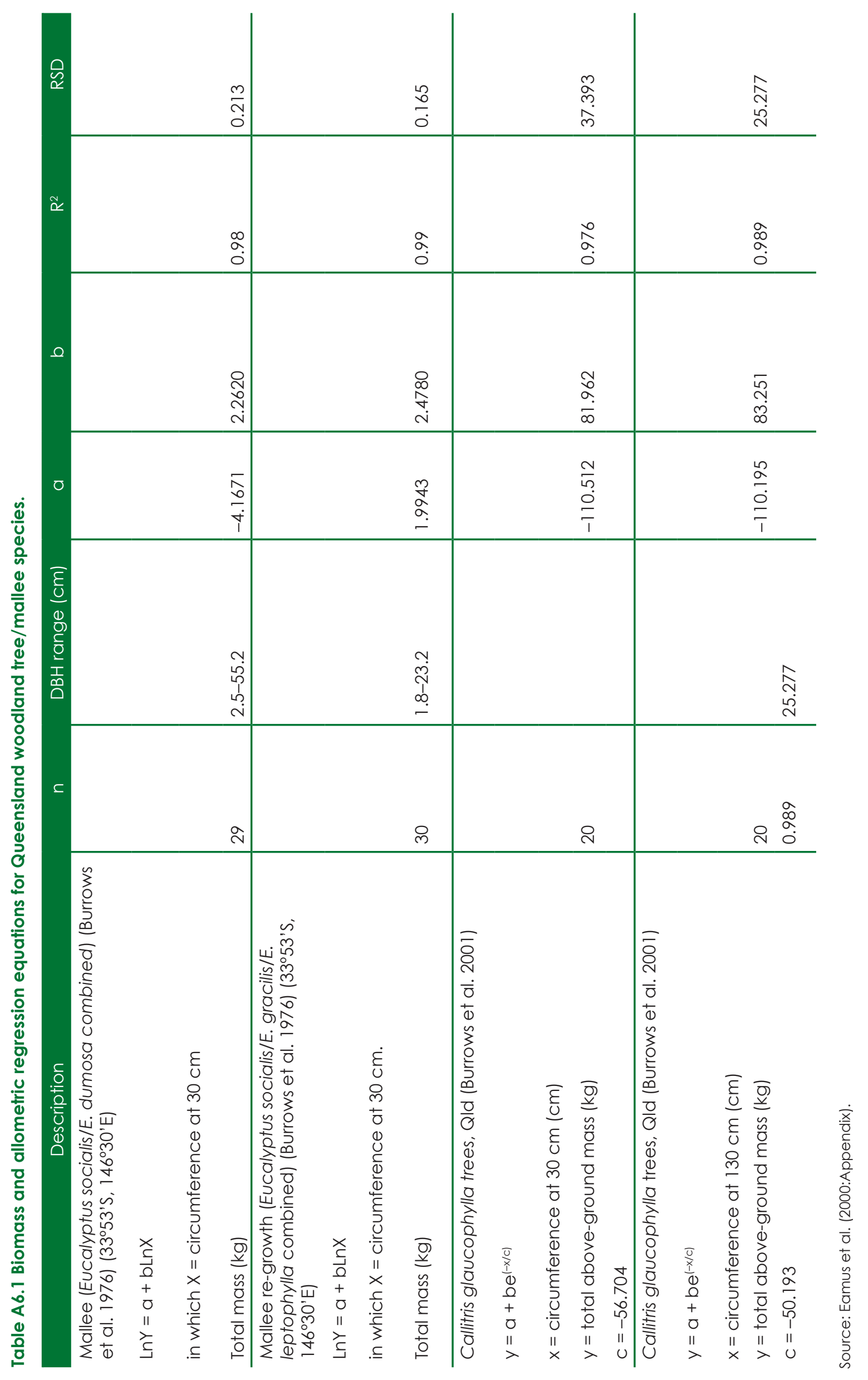

() 


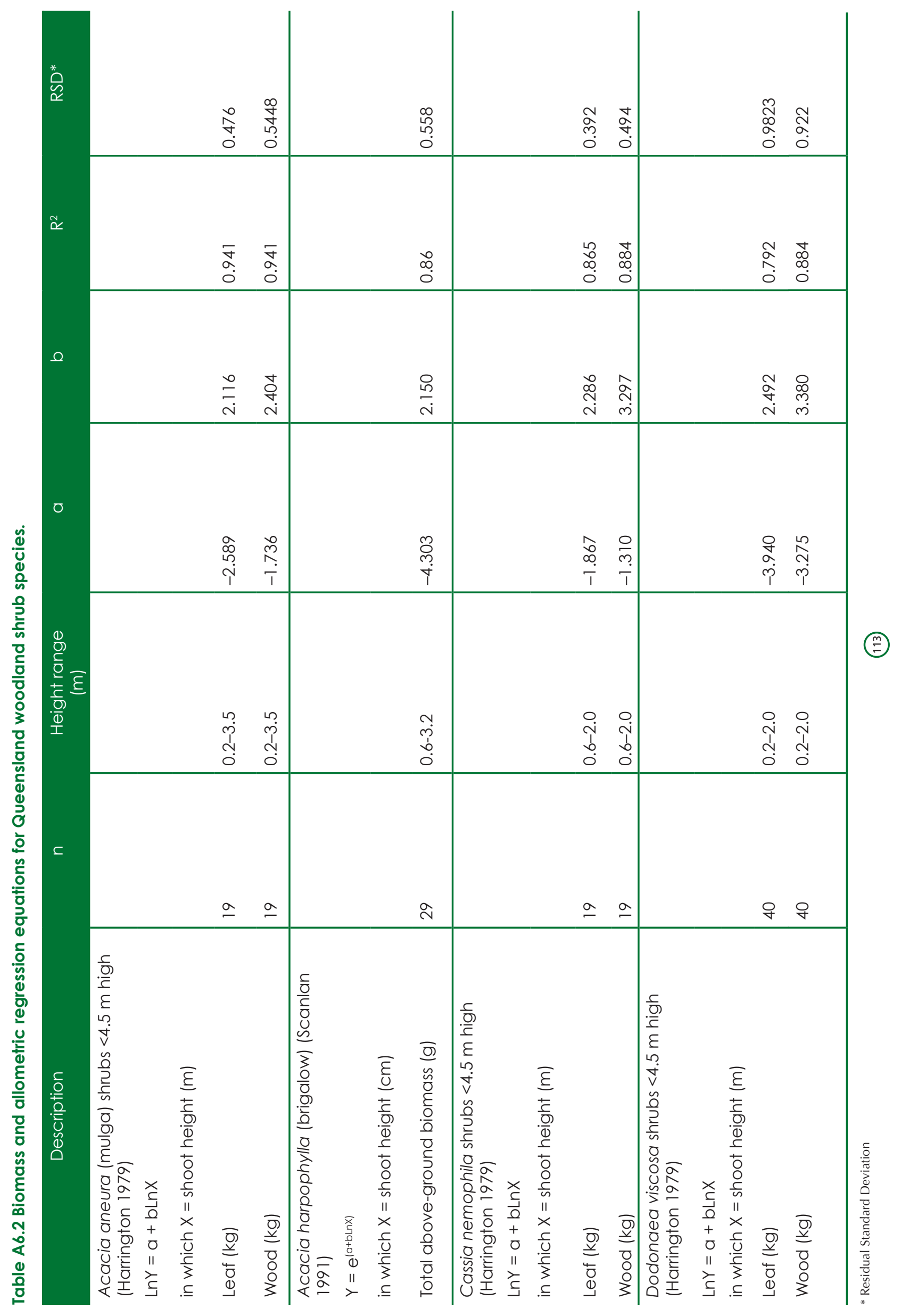




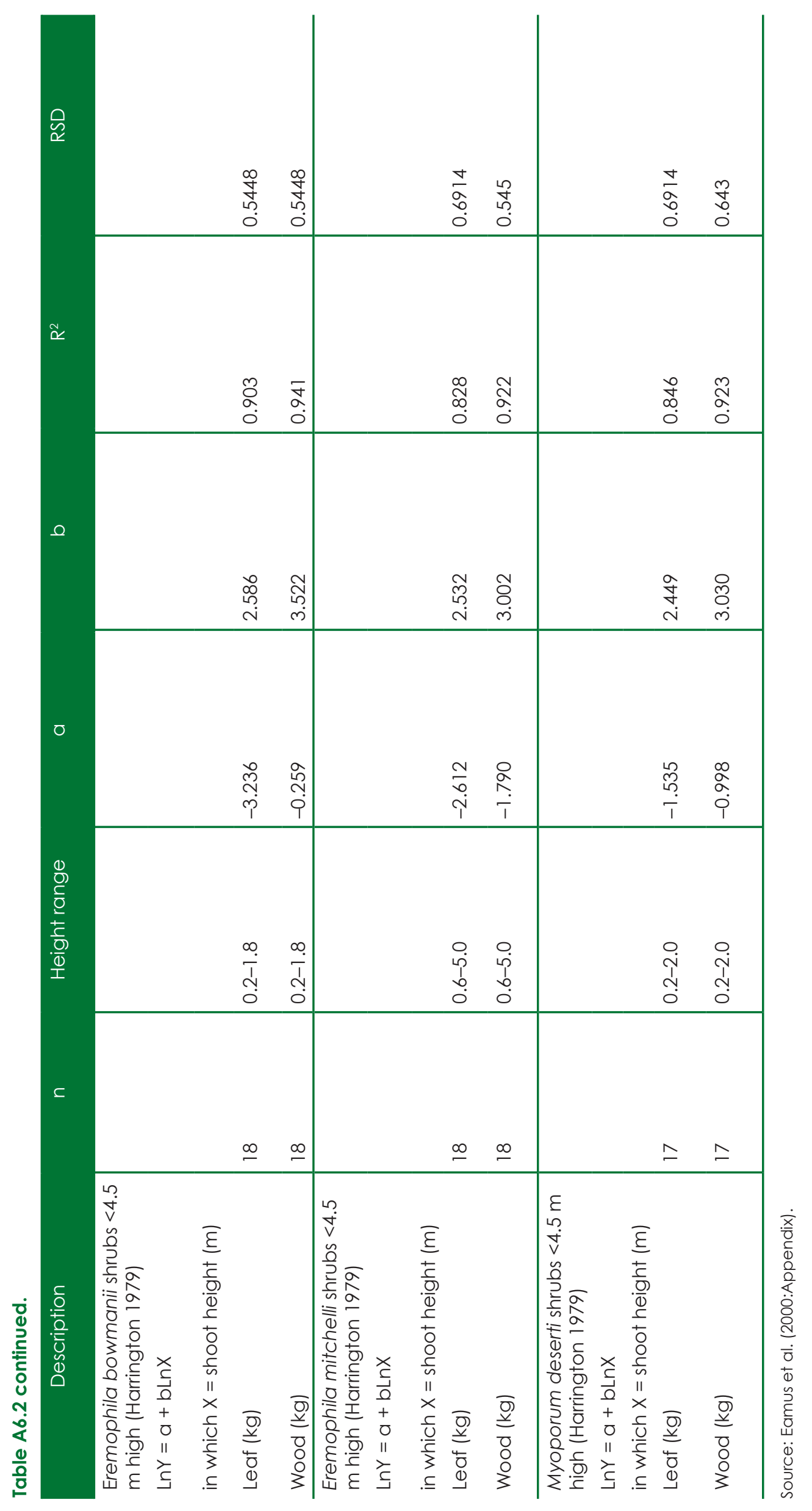

E) 


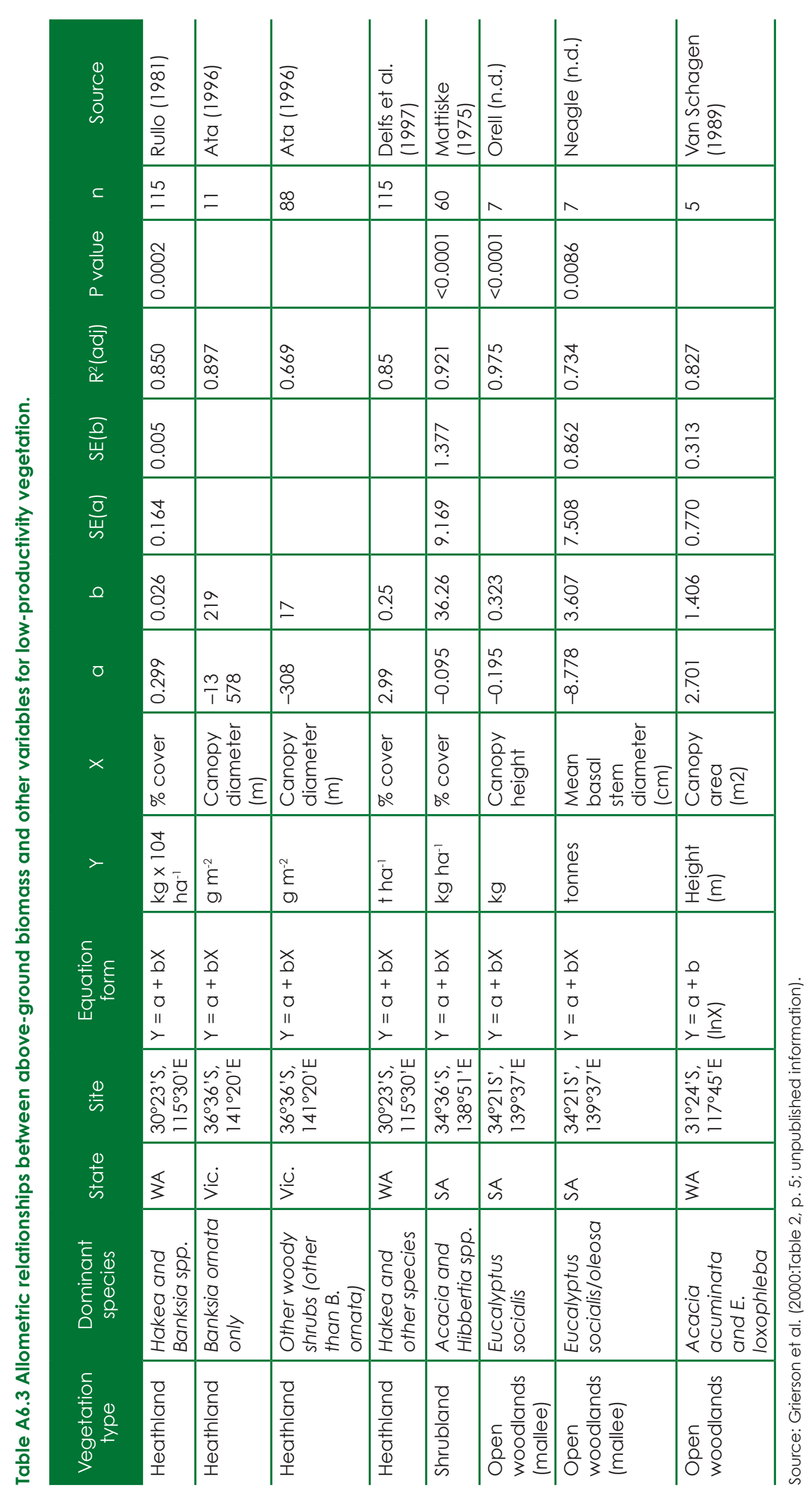

() 
Table A6.4 Allometric relationships (InBiomass $=a+b$ InDiameter at $30 \mathrm{~cm}$ ) between above-ground biomass and coarse root biomass with stem diameter for Eucalyptus populnea woodlands along a rainfall gradient.

\begin{tabular}{l|l|l|l|l|l|l|l|l|l} 
Location & \multicolumn{1}{c}{ Site } & $\begin{array}{l}\text { Rainfall a } \\
(\mathrm{mm})\end{array}$ \\
\hline Oakvale & $\begin{array}{l}30.92^{\circ} \mathrm{S}, \\
46.50^{\circ} \mathrm{E}\end{array}$ & 367 & -1.370 & 2.079 & 0.443 & 0.114 & 0.0391 & 9 & $15.0-107.9$ \\
\hline Roma & $\begin{array}{l}25.75^{\circ} \mathrm{S}, \\
148.41^{\circ} \mathrm{E}\end{array}$ & 602 & -2.824 & 2.581 & 0.147 & 0.056 & 0.0454 & 10 & $1.6-51.5$ \\
Rockhampton & $\begin{array}{l}23.17^{\circ} \mathrm{S}, \\
50.56^{\circ} \mathrm{E}\end{array}$ & 1103 & -2.388 & 2.411 & 0.327 & 0.101 & 0.0967 & 9 & $3.2-71.1$ \\
\hline
\end{tabular}

Source: Zerihun et al. (2006).

Table A7 Distribution, ecology and wood properties of species used by Justin Jonson to derive allometric equations*.

\begin{tabular}{|c|c|c|c|c|c|}
\hline $\begin{array}{l}\text { Species } \\
\text { name }\end{array}$ & $\begin{array}{l}\text { Common } \\
\text { name }\end{array}$ & Distribution & Ecology & $\begin{array}{l}\text { Source } \\
\text { (see } \\
\text { below) }\end{array}$ & $\begin{array}{l}\text { 'Basic } \\
\text { density } \\
\mathrm{kg} \mathrm{m}^{-3} \text { ) }\end{array}$ \\
\hline $\begin{array}{l}\text { Eucalyptus } \\
\text { platypus }\end{array}$ & Moort & $\begin{array}{l}\text { Albany to } \\
\text { Esperance }\end{array}$ & $\begin{array}{l}\text { Southern coastal and sub-coastal } \\
\text { plains (B\&K). Sandy soils, loamy clay, } \\
\text { laterite. Plains, hilly and rocky country } \\
\text { (Florabase, <http://florabase.calm. } \\
\text { wa.gov.au/browse/profile/5643) }\end{array}$ & 2 & \\
\hline E. falcata & $\begin{array}{l}\text { Silver } \\
\text { mallee }\end{array}$ & $\begin{array}{l}\text { In a triangle } \\
\text { bounded by } \\
\text { Albany-Perth- } \\
\text { Esperance }\end{array}$ & $\begin{array}{l}\text { South-west, outside of wetter areas } \\
\text { (B\&K). Sand over laterite, often } \\
\text { with gravel, limestone. Sandplains, } \\
\text { breakaways, slight rises, hilltops, valleys, } \\
\text { disturbed land, road verges (Florabase) }\end{array}$ & 2 & \\
\hline E. flocktoniae & Merrit & $\begin{array}{l}\text { Widespread in } \\
\text { wheatbelt and } \\
\text { Goldfields }\end{array}$ & Sandy loam or clay, laterite (Florabase) & 2 & $\begin{array}{l}1145 \\
1074 \\
(820)\end{array}$ \\
\hline E. captiosa & & $\begin{array}{l}\text { Wheatbelt, } \\
\text { Albany to Hyden }\end{array}$ & $\begin{array}{l}\text { White or yellow sand. Sandplains, } \\
\text { lateritic rises (Florabase) }\end{array}$ & 2 & \\
\hline E. annulata & $\begin{array}{l}\text { Open- } \\
\text { fruited } \\
\text { mallee }\end{array}$ & $\begin{array}{l}\text { Southern } \\
\text { wheatbelt and } \\
\text { southern coastal } \\
\text { areas from } \\
\text { near Albany to } \\
\text { Balladonia }\end{array}$ & $\begin{array}{l}\text { Clay, sandy clay, clay loam } \\
\text { (Florabase) }\end{array}$ & 2 & $\begin{array}{l}959 \\
750\end{array}$ \\
\hline $\begin{array}{l}\text { E. } \\
\text { occidentalis }\end{array}$ & $\begin{array}{l}\text { Swamp } \\
\text { yate }\end{array}$ & $\begin{array}{l}\text { Southern } \\
\text { wheatbelt and } \\
\text { sub-coastal areas }\end{array}$ & $\begin{array}{l}\text { Usually confined to wet, clayey } \\
\text { depressions (B\&K), Sandy or clayey } \\
\text { soils. Alluvial flats, low-lying wet areas, } \\
\text { around salt lakes, hills (Florabase) }\end{array}$ & 2 & 776 \\
\hline $\begin{array}{l}\text { Allocasuarina } \\
\text { huegeliana }\end{array}$ & & $\begin{array}{l}\text { Occurs from } \\
\text { Murchison River } \\
\text { and Mingenew } \\
\text { south to the } \\
\text { south coast and } \\
\text { east to Newman } \\
\text { Rock, west of } \\
\text { Balladonia, WA }\end{array}$ & Associated with granite & 3 & $\begin{array}{l}885 \\
(700)\end{array}$ \\
\hline $\begin{array}{l}\text { Acacia } \\
\text { saligna }\end{array}$ & & $\begin{array}{l}\text { Wheatbelt } \\
\text { and southern } \\
\text { Goldfields }\end{array}$ & & 4 & \\
\hline
\end{tabular}

* The basic density values are estimated for air-dry (12 per cent moisture content) wood.

Sources: 1. llic et al. (2000); 2. Brooker and Kleinig (2001); 3. Flora of Australia Online (<http://www.environment.gov.au/biodiversity/abrs/ online-resources/flora/main/>); 4. Florabase: The Western Australian Flora (<http://florabase.calm.wa.gov.au/>). 


\section{REFERENCES}

Australian Surveying and Land Information Group (AUSLIG) 1990, Atlas of Australian Resources. Volume 6: Vegetation, (Third series), Australian Surveying and Land Information Group, Department of Administrative Services, Canberra. [Present and natural vegetation 1:5 million digitised maps are available for download, <https:// www.ga.gov.au/>]

Beard, J. S. 1968, 'The vegetation of the Boorabbin and Lake Johnston areas, Western Australia', Proceedings of the Linnean Society of New South Wales, vol. 93, pp. 239-68.

Beard, J. S. 1972, Vegetation Survey of Western Australia-The vegetation of the Hyden area, map and explanatory memoir, Vegmap Publications, Sydney.

Beard, J. S. 1976, The Vegetation of the Boorabbin and Lake Johnston Areas: Vegetation survey of Western Australia, 1:250,000 map and explanatory memoir, Vegmap Publications, Western Australia.

Bejan, A., Lorente, S. and Lee, J. 2008, 'Unifying constructal theory of tree roots, canopies and forests', Journal of Theoretical Biology, vol. 254, pp. 529-40.

Berry, S. L. and Roderick, M. L. 2002, 'Estimating mixtures of leaf functional types using continental-scale satellite and climatic data', Global Ecology and Biogeography, vol. 11, pp. 23-40.

Berry, S. L. and Roderick, M. L. 2006, 'Changing Australian vegetation from 1788 to 1988: effects of $\mathrm{CO}_{2}$ and land use change', Australian Journal of Botany, vol. 54, pp. 325-8.

Berry, S., Mackey, B. and Brown, T. 2007, 'Potential applications of remotely sensed vegetation greenness to habitat analysis and the conservation of dispersive fauna', Pacific Conservation Biology, vol. 13, pp. 120-7.

Bianchi, P., Bridge, P. and Tovey, R. 2008, Early Woodlines of the Goldfields-The untold story of the woodlines to World War II, (Second edition), Hesperian Press, Carlisle, WA.

Boland, D. J., Brooker, M. I. H., Chippendale, G. M., Hall, N., Hyland, B. P. M., Johnston, R. D., Kleinig, D. A. and Turner. J. D. 1984, Forest Trees of Australia, CSIRO, Melbourne.

Bond, W. J. and Keeley, J. E. 2005, "Fire as a global "herbivore": the ecology and evolution of flammable ecosystems', Trends in Ecology and Evolution, vol. 20, pp. 387-94.

Bonham, C. D. 1989, Measurements for Terrestrial Vegetation, John Wiley \& Sons, New York, pp. 159-65.

Bradby, K. 2008, 'Box 1.2-drawing a line in the sand', in A. Watson, S. Judd, J. Watson, A. Lam and D. Mackenzie, The Extraordinary Nature of the Great Western Woodlands, The Wilderness Society of Western Australia Inc., WA.

Brady, N. C. and Weil, R. R. 2002, The Nature and Properties of Soils, (Thirteenth edition), Prentice Hall, Upper Saddle River, NJ. 
Brooker, M. I. H. and Kleinig, D. A. 2001, Field Guide to Eucalypts. South-western and southern Australia. Volume 2, (Second edition), Bloomings Books, Melbourne.

Bryant, C. 2008, Understanding bushfire: trends in deliberate vegetation fires in Australia, Australian Institute of Criminology Technical and Background Paper No. 27, Australian Government, Canberra.

Bunting, J. A. and van de Graaff, W. J. E. 1977, Cundeelee, Western Australia, 1:250 000 geological series explanatory notes, Sheet SH51-11, Explanatory notes, Bureau of Mineral Resources, Australia.

Burrows, W. H., 1976, Aspects of nutrient cycling in semi-arid mallee and mulga communities. PhD Thesis, Australian National University, Canberra.

Burrows, W. H., Henry, B. K., Back, P. V., Hoffmann, M. B., Tait, L. J., Anderson, E. R., Menke, N., Danaher, T., Carter, J. O. and McKeon, G. M. 2002, 'Growth and carbon stock change in eucalypt woodlands in northeast Australia: ecological and greenhouse sink implications', Global Change Biology, vol. 8, pp. 769-84.

Burrows, W. H., Hoffmann, M. B., Compton, J. F. and Back, P. V. 2001, Allometric relationships and community biomass stocks in white cypress pine (Callitris glaucophylla) and associated eucalypts of the Carnarvon area-south central Queensland, NCAS Technical Report No. 33, Australian Greenhouse Office, Canberra.

Burrows, W. H., Hoffmann, M. B., Compton, J. F., Back, P. V. and Tait, L. J. 2000, 'Allometric relationships and community biomass estimates for some dominant eucalypts in central Queensland woodlands', Australian Journal of Botany, vol. 48, pp. 707-14.

Chen, X., Hutley, L. B. and Eamus, D. 2003, 'Carbon balance of a tropical savanna of northern Australia', Oecologia, vol. 137, pp. 405-16.

Chin, R. J. and Smith, R. A. 1981, Jackson, Western Australia, 1:250 000 geological series explanatory notes, Sheet SH/50-12, Geological Survey of Western Australia, Record 1981/7.

Chin, R. J., Hickman, A. H. and Thom, R. 1984, Hyden, Western Australia, 1:250 000 geological series explanatory notes, Sheet SI/50-04, Geological Survey of Western Australia, Record 1982/5.

Cook, G. D., Liedloff, A. C., Eager, R. W., Chen, X., Williams, R. J., O'Grady, A. P. and Hutley, L. B. 2005, 'The estimation of carbon budgets of frequently burnt tree stands in savannas of northern Australia, using allometric analysis and isotopic discrimination', Australian Journal of Botany, vol. 53, pp. 621-30.

Costa, P. M. 2009, Compensation for carbon stock maintenance in forests as an alternative to avoiding carbon flows, Unpublished report, Oxford Centre for Tropical Forests, Environmental Change Institute, University of Oxford, UK.

CSIRO 2007, Australian Soil Resource Information System, CSIRO, Canberra, <http:// www.asris.csiro.au/index_ie.html>

Dean, C. and Eldridge, D. J. 2008, Prognosis for carbon sequestration in rangelands upon destocking, RIRDC Publication No. 08, Rural Industries Research and Development Corporation, Canberra. 
Department of Environment, Water, Heritage and the Arts (DEWHA) 2005, National Vegetation Information System. Australia-present major vegetation groups-NVIS stage 1, Version 3.0 (Albers 100m analysis product), Department of Environment, Water, Heritage and the Arts, Australian Government, Canberra. [Spatial data are available for download, viewed 5 February 2009, <http://www.environment.gov. au/erin/nvis/mvg/index.html> Source data for Western Australia: WA Department of Agriculture.]

Doepel, J. J. G. 1973, Norseman, Western Australia, 1:250 000 geological series explanatory notes, Sheet SI/51-02, Geological Survey of Western Australia, Perth.

Doepel, J. J. G. and Lowry, D. C. 1970a, Balladonia, Western Australia, 1:250 000 geological series explanatory notes, Sheet SI/51-03, Bureau of Mineral Resources, Australia.

Doepel, J. J. G. and Lowry, D. C. 1970b, Zanthus, Western Australia, 1:250 000 geological series explanatory notes, Sheet SH/51-15, Geological Survey of Western Australia, Perth.

Donohue, R. J., McVicar, T. R. and Roderick, M. L. 2009, 'Climate-related trends in Australian vegetation cover as inferred from satellite observations, 1981-2006', Global Change Biology, doi:10.1111/j.1365-2486.2008.01746.x.

Duncan, S., Traill, B. J. and Watson, C. 2006, Vertebrate Fauna of the Honman Ridge Bremer Range District, Great Western Woodlands, Western Australia, The Wilderness Society, West Perth.

Eamus, D., McGuinness, K. and Burrows, W. 2000, Review of allometric relationships for estimating woody biomass for Queensland, the Northern Territory and Western Australia, NCAS Technical Report No. 5a, Australian Greenhouse Office, Canberra.

Fensham, R. J. 2005, 'Monitoring standing dead wood for carbon accounting in tropical savanna', Australian Journal of Botany, vol. 53, pp. 631-8.

Fensham, R. J., Fairfax, R. J., Holman, J. E. and Whitehead, P. J. 2002, 'Quantitative assessment of vegetation structural attributes from aerial photography', International Journal of Remote Sensing, vol. 23, pp. 2293-317.

Gallant, J. C. and Dowling, T. I. 2003, 'A multi resolution index of valley bottom flatness for mapping depositional areas', Water Resources Research, vol. 39, p. 1347.

Gee, R. D. 1979, Southern Cross, Western Australia, 1:250 000 geological series explanatory notes, Sheet SH/50-16, (First edition), Geological Survey of Western Australia, Perth, Record 1979/5.

Geological Survey of Western Australia 2007, Atlas of 1:250 000 Geological Series Map Images, Western Australia, April 2007 update, WA Department of Industry and Resources, Perth, <www.doir.wa.gov/gswa>

Geoscience Australia 1993, Australian Land Tenure 1993, National Mapping Division, Geoscience Australia, Canberra, <http://www.ga.gov.au/>

Geoscience Australia 2009, What Causes Bushfires?, Geoscience Australia, Canberra, viewed 3 March 2009, <http://www.ga.gov.au/hazards/bushfire/causes.jsp> 
Geoscience Australia 2010, Landsat Continental Mosaic (AGO) Product Suite, Geoscience Australia, Canberra, <http://www.ga.gov.au/remote-sensing/getsatellite-imagery-data/ordering/pricing/landsat-continental-mosaic/>

Gifford, R. M. 2000, Carbon contents of above-ground tissues of forest and woodland trees, NCAS Technical Report No. 22, Australian Greenhouse Office, Canberra.

Gill, A. M. 1975, 'Fire and the Australian flora: a review', Australian Forestry, vol. 38, pp. 4-25.

Gower, C. F. and Bunting, J. A. 1976, Lake Johnston, Western Australia, 1:250 000 geological series explanatory notes, Sheet SI/51-01, Bureau of Mineral Resources and Geological Survey of Western Australia, Perth.

Grierson, P. F., Adams, M. A. and Attiwill, P. M. 1992, 'Estimates of carbon storage in the above-ground biomass of Victoria's forests', Australian Journal of Botany, vol. 40, pp. 631-40.

Grierson, P., Williams, K. and Adams, M. 2000, Review of unpublished biomass-related information: Western Australia, South Australia, New South Wales and Queensland, NCAS Technical Report No. 25, Australian Greenhouse Office, Canberra.

Groves, R. H. 1965, 'Growth of heath vegetation II. The seasonal growth of a heath on ground-water podzol at Wilson's Promontory, Victoria', Australian Journal of Botany, vol. 13, pp. 281-9.

Groves, R. H. and Specht, R. L. 1965, 'Growth of heath vegetation I. Annual growth curves of two heath ecosystems in Australia', Australian Journal of Botany, vol. 13, pp. 261-80.

Hadlington, P. 1987, Australian Termites and Other Common Timber Pests, UNSW Press, Kensington, NSW.

Harms, B. P., Dalal, R. C. and Cramp, A. P. 2005, 'Changes in soil carbon and soil nitrogen after tree clearing in the semi-arid rangelands of Queensland', Australian Journal of Botany, vol. 53, pp. 639-50.

Harrington, G. 1979, 'Estimates of above-ground biomass of trees and shrubs in a Eucalyptus populnea F. Muell. woodland by regression of mass on trunk diameter and plant height', Australian Journal of Botany, vol. 27, pp. 135-47.

Helms, R. 1892-96, 'Anthropology. Scientific results of the Elder exploring expedition', Transactions of the Royal Society of South Australia, vol. XVI, pp. 237-332.

Henson, P. and Blewett, R. 2006, 'Going for gold in the eastern Yilgarn', AusGeo News, vol. 82 (June).

Hopkins, A. J. M. and Robinson, C. J. 1981, 'Fire induced structural change in a Western Australian woodland', Australian Journal of Ecology, vol. 6, pp. 177-88.

Houghton, R. A. 2007, 'Balancing the global carbon budget', Annual Review of Earth and Planetary Sciences, vol. 35, pp. 313-47.

Hunter, W. M. 1989, Explanatory notes on the Boorabbin 1:250 000 geological sheet, Western Australia, (Second edition), Geological Survey of Western Australia, Perth, Record 1989(3). 
Hutchinson, M. F. 2005, ANUCLIM ver. 5.1, Centre for Resource and Environmental Studies, The Australian National University, Canberra, <http://cres.anu.edu.au/ outputs/anuclim.php>

Hutchinson, M., Stein, J., Stein, J. L., Anderson, H. and Tickle, P. 2008, Geodata 9 Second DEM and D8 User Guide, Fenner School of Environment and Society, The Australian National University and Geoscience Australia, Canberra, <http://fennerschool. anu.edu.au/publications/software/>

llic, J., Boland, D., McDonald, M., Downes, G. and Blakemore, P. 2000, Woody density phase 1-state of knowledge, NCAS Technical Report No. 18, Australian Greenhouse Office, Canberra.

Intergovernmental Panel on Climate Change (IPCC) 2007, The Fourth Assessment Report Climate Change 2007: Synthesis report, Intergovernmental Panel on Climate Change, Geneva, <http://www.ipcc.ch/>

Jobbágy, E. G. and Jackson, R. B. 2000, 'The vertical distribution of soil organic carbon and its relation to climate and vegetation', Ecological Applications, vol. 10, pp. 423-36.

Jones, R. 1968, 'Estimating productivity and apparent photosynthesis from differences in consecutive measurements of total living plant parts of an Australian heathland', Australian Journal of Botany, vol. 16, pp. 589-602.

Keith, H., Mackey, B., Berry, S., Lindenmayer, D. and Gibbons, P. 2010. 'Estimating carbon carrying capacity in natural forest ecosystems across heterogeneous landscapes: addressing sources of error', Global Change Biology, vol. 16. pp.2971-2989.

Kern, A. M. 1995, Hydrogeology of the Boorabbin 1:250 000 sheet: Western Australian Geological Survey, 1:250 000 Hydrogeological Series Explanatory Notes, Geological Survey of Western Australia, Perth.

Kriewaldt, M. 1967, Kalgoorlie, Western Australia, 1:250 000 geological series explanatory notes, Sheet SH/51-09, Bureau of Mineral Resources and Geological Survey of Western Australia, Perth.

Lawford, G., Stanley, S. and Kilgour, B. 1998, Population Centres, National Geoscience Dataset, Geoscience Australia, Canberra, <http://www.ga.gov.au/>

Linacre, E. and Hobbs, J. 1977, The Australian Climatic Environment, John Wiley \& Sons, Brisbane.

Looby, M. J. 2007, Tree hollows, tree dimensions and tree age in Eucalyptus microcarpa Maiden (grey box) in Victoria, Masters thesis, March 2007, School of Resource Management, Faculty of Land and Food Resources, The University of Melbourne, Vic.

Low, A. B. and Lamont, B. B. 1990, 'Aerial and below-ground phytomass of Banksia scrub-heath at Eneabba, south-western Australia', Australian Journal of Botany, vol. 38, pp. 351-9.

Lowry, D. C. 1970, Culver, Western Australia, 1:250 000 geological series explanatory notes, Sheet SI/51-4, Geological Survey of Western Australia, Bureau of Mineral Resources, Geology and Geophysics, Perth. 
Lowry, D. C. and Doepel, J. J. G. 1974, Malcolm-Cape Arid, Western Australia, 1:250 000 geological series explanatory notes, Sheet SI/51-7, Geological Survey of Western Australia, Perth.

Mackey, B. G., Keith, H., Berry, S. L. and Lindenmayer, D. B. 2008, Green Carbon: The role of natural forests in carbon storage. Part 1. A green carbon account of Australia's south-eastern eucalypt forests, and policy implications, ANU E Press, Canberra.

Mackey, B. G., Lindenmayer, D. B., Gill, A. M., McCarthy, A. M. and Lindesay, J. A. 2002, Wildlife, Fire and Future Climate: A forest ecosystem analysis, CSIRO Publishing, Melbourne.

Mitchell, K. 2007, Quantitative Analysis by the Point-Centred Quarter Method. Version 2.15, Self-published, <http://people.hws.edu/mitchell/PCQM.pdf>

Morgan, K. H. and Peers, R. 1973, Esperance-Mondrain Island, Western Australia, 1:250 000 geological series explanatory notes, Sheet SI/51-06, 10, Bureau of Mineral Resources, Australia.

National Wildfire Coordinating Group (NWCG) 2005, Wildfire Origin and Cause Determination Handbook, NWCG Handbook 1, National Wildfire Coordinating Group Fire Investigation Working Team, <www.nwcg.gov>

Newby, K. R., Western Australian Museum and Western Australia Biological Surveys Committee 1984, The Biological Survey of the Eastern Goldfields of Western Australia. Volumes 1-12, Western Australian Museum, Perth.

Ogden, J. 1978, 'On the dendrochronological potential of Australian trees', Australian Journal of Ecology, vol. 3, pp. 339-56.

Paget, M. J. and King, E. A. 2008, MODIS land data sets for the Australian region, CSIRO Marine and Atmospheric Research internal report No. 004, CSIRO Marine and Atmospheric Research, Canberra, [for further information with regard to this data set, contact: Matt Paget, <matt.paget@csiro.au> or Edward King, <edward. king@csiro.au>].

Raison, J., Keith, H., Barrett, D., Burrows, B. and Grierson, P. 2003, Spatial estimates of biomass in 'mature' native vegetation, NCAS Technical Report No. 44, Australian Greenhouse Office, Canberra.

Recher, H., Davis, W. jr, Berry, S., Mackey, B., Watson, A. and Watson, J. 2007, 'Conservation inverted: birds in the Great Western Woodlands', Wingspan, vol. 17, no. 4, pp. 16-19.

Roderick, M. L., Noble, I. R. and Cridland, S. W. 1999, 'Estimating woody and herbaceous vegetation cover from time series satellite observations', Global Ecology and Biogeography Letters, vol. 8, pp. 501-8.

Scanlan, J. C. 1991, 'Woody overstorey and herbaceous understorey biomass in Acacia harpophylla (brigalow) woodlands', Australian Journal of Ecology, vol. 16, pp. 521-9.

Siemon, G. R. and Kealley, I. G. 1999, Goldfields timber research project. Report by the Research Project Steering Committee, Department of Commerce and Trade, Goldfields Esperance Development Commission, Department of Conservation and 
Land Management, Goldfields Specialty Timber Industry Group Inc., Curtin University, Kalgoorlie Campus, WA.

Skjemstad, J. O., Clarke, P., Taylor, J. A., Oades, J. M. and McClure, S. G. 1996, 'The chemistry and nature of protected carbon in soil', Australian Journal of Soil Research, vol. 34, pp. 251-71.

Sofoulis, J. 1966, Widgiemooltha, Western Australia, 1:250 000 geological series explanatory notes, Sheet SH/51-14, (First edition), Bureau of Mineral Resources and Geological Survey of WA, Perth.

Specht, R. L. 1966, 'The growth and distribution of mallee-broombush (Eucalyptus incrassata-Melaleuca uncinata association) and heath vegetation near Dark Island Soak, Ninety-Mile Plain, South Australia', Australian Journal of Botany, vol. 14, pp. 361-71.

Specht, R. L. 1981, 'Major vegetation formations in Australia', in A. Keast (ed.), Ecological Biogeography of Australia, Dr W. Junk, The Hague, pp. 165-297.

Specht, R. L., Rayson, P. and Jackman, M. E. 1958, 'Dark Island heath (Ninety-Mile Plain, South Australia) VI. Pyric succession: changes in composition, coverage, dry weight, and mineral nutrient status', Australian Journal of Botany, vol. 6, pp. 59-88.

Thom, R., Lipple, S. L. and Sanders, C. C. 1977, Ravensthorpe, Western Australia, 1:250 000 geological series explanatory notes, Sheet SI/51-05, Bureau of Mineral Resources and Geological Survey of Western Australia, Perth.

Tongway, D. J. and Hindley, N. L. 2004, Landscape Function Analysis: Procedures for monitoring and assessing landscapes, CSIRO Sustainable Ecosystems, Canberra.

United Nations Framework Convention on Climate Change (UNFCCC) 2007, Reducing emissions from deforestation in developing countries: approaches to stimulate action decision 2/CP.13, UN Framework Convention on Climate Change, Conference of the Parties 13, Bali, Indonesia.

Warde, W. and Petranka, J. W. 1981, 'A correction factor for missing point-center quarter data', Ecology, vol. 62, pp. 491-4.

Wellington, A. B. and Noble, I. R. 1985, 'Post-fire recruitment and mortality in a population of the mallee Eucalyptus incrassata in semi-arid, south-eastern Australia', Journal of Ecology, vol. 73, pp. 645-56.

Western Australia Forests Department 1934-70, Report on the Operations of the Forests Department for the Year Ended 30th June, Individual reports for the years 1934 to 1970, Government Printer, Perth.

Western Australia Forests Department 1969, Fifty Years of Forestry in Western Australia. Supplement to the 1968/69 report on the operations of the Forests Department for the year ended 30th June, Western Australia Forests Department, Perth.

Williams, I. 1970, Kurnalpi, Western Australia, 1:250 000 geological series explanatory notes, Sheet SH/51-10, Bureau of Mineral Resources, Australia.

Williams, R. J., Zerihun, A., Montagu, K. D., Hoffman, M., Hutley, L. B. and Chen, X. 2005, 'Allometry for estimating aboveground tree biomass in tropical and subtropical woodlands: towards general predictive equations', Australian Journal of Botany, vol. 53, pp. 607-19. 
Woldendorp, G. and Keenan, R. J. 2005, 'Coarse woody debris in Australian forest ecosystems: a review', Austral Ecology, vol. 30, pp. 834-43.

Wynn, J. G., Bird, M. I., Vellen, L., Grand-Clement, E., Carter, J. and Berry, S. L. 2006, 'Continental-scale measurement of the soil organic carbon pool with climatic, edaphic, and biotic controls', Global Biogeochemical Cycles, 20, GB1007, doi:10.1029/2005GB002576.

Zerihun, A., Montagu, K. D., Hoffmann, M. B. and Bray, S. G. 2006, 'Patterns of belowand aboveground biomass in Eucalyptus populnea woodland communities of northeast Australia along a rainfall gradient', Ecosystems, vol. 9, pp. 501-15.

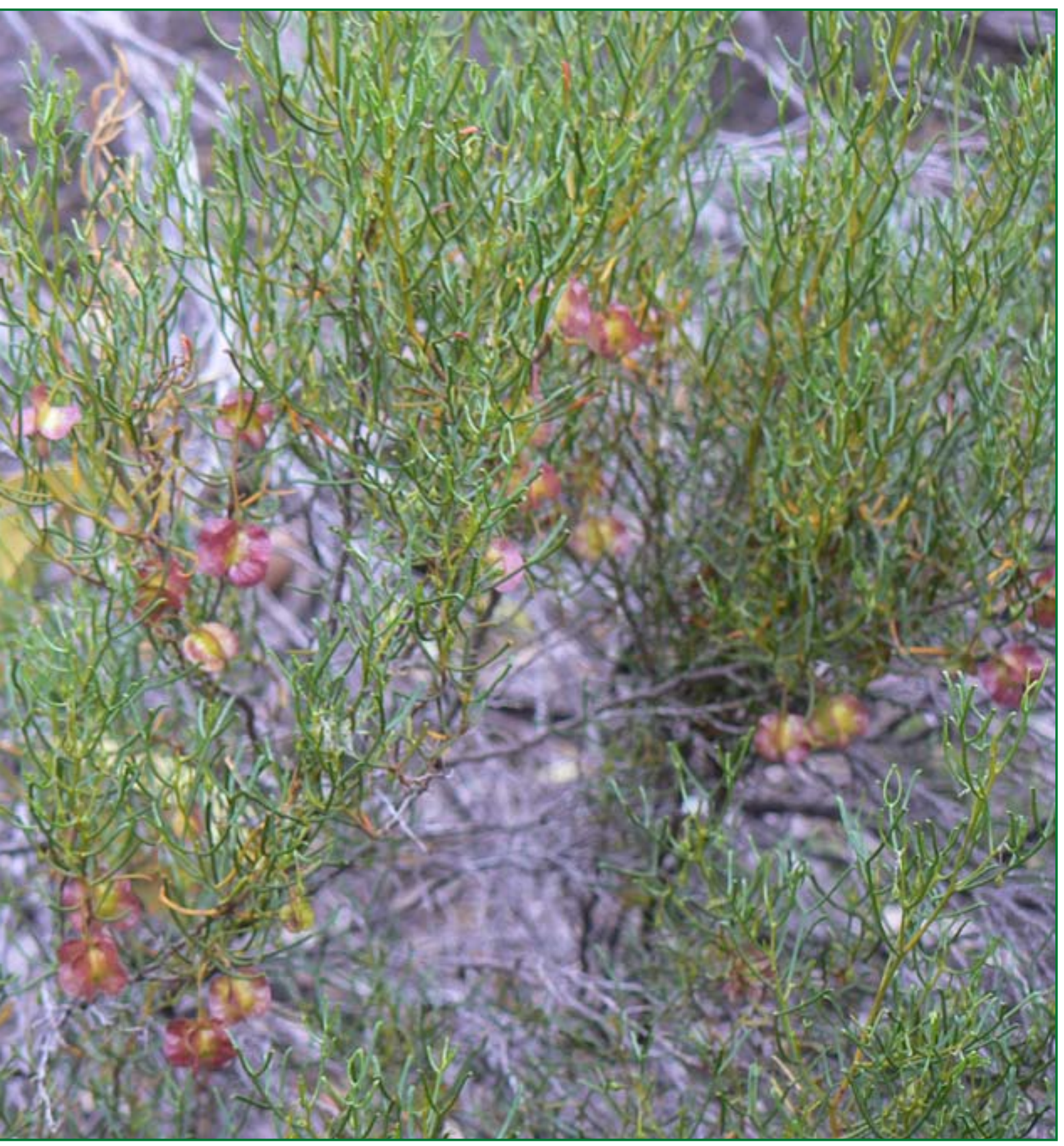

